UNIVERSIDADE DE BRASÍLIA

FACULDADE DE ARQUITETURA E URBANISMO

PROGRAMA DE PÓS-GRADUAÇÃO

GESTÃO DE ÁGUA EM EDIFÍCIOS PÚBLICOS ADMINISTRATIVOS: RECOMENDAÇÕES BASEADAS EM ESTUDO DE CASO NO TCU

MARCELO ALBUQUERQUE LIMA

BRASÍLIA/DF 



\section{GESTÃo DE ÁGUA EM EDIFÍCIOS PÚBLICOS ADMINISTRATIVOS: RECOMENDAÇÕES BASEADAS EM ESTUDO DE CASO NO TCU}

Dissertação apresentada ao Programa de PósGraduação da Faculdade de Arquitetura e Urbanismo da Universidade de Brasília - UnB, como requisito parcial para a obtenção do título de Mestre em Arquitetura e Urbanismo.

Área de Concentração: Tecnologia, Ambiente e Sustentabilidade

Linha de Pesquisa: Sustentabilidade, Qualidade e Eficiência do Ambiente Construído

Orientadora: Prof. Dra. Raquel Naves Blumenschein

Co-orientador: Prof. Dr. Daniel Richard Sant'Ana

BRASÍLIA/DF 



\title{
GESTÃo DE ÁGUA EM EDIFÍCIOS PÚBLICOS ADMINISTRATIVOS: RECOMENDAÇÕES BASEADAS EM ESTUDO DE CASO NO TCU
}

\author{
Dissertação apresentada ao Programa de Pós- \\ Graduação da Faculdade de Arquitetura e Urbanismo \\ da Universidade de Brasília - UnB, como requisito \\ parcial para a obtenção do título de Mestre em \\ Arquitetura e Urbanismo.
}

Aprovada em I

Banca examinadora:

Prof. Dr ${ }^{\mathrm{a}}$. Raquel Naves Blumenschein - Orientadora - FAU/UnB

Prof. Dr. Daniel Richard Sant'Ana - Co-orientador - FAU/UnB

Prof. Dra . Cláudia Naves David Amorim - FAU/UnB

Prof. Dr. Marco Antonio Almeida de Souza - ENC/UnB 

Dedico este trabalho a minha esposa Cláudia. Linda, batalhadora, companheira de hoje e sempre. Simplesmente a mulher da minha vida. 



\section{AGRADECIMENTOS}

Agradeço a Deus e a todas as forças, divindades e espíritos de luz que, de alguma forma, me guiaram e protegeram nesta caminhada;

Agradeço imensamente a meus pais, Lima e Marlene, pela educação que me proporcionaram e pelos ensinamentos da vida, que foram muito valiosos na formação do meu caráter;

Também agradeço à minha filha Ana Beatriz, pela paciência nos meus momentos de ausência; Agradeço a minha família e amigos, pelas palavras de estímulo em prosseguir com meu sonho;

Meu eterno e especial agradecimento à Prof. Raquel Blumenschein pela oportunidade, por acreditar no meu potencial e pela sensibilidade e segurança em me orientar e me conduzir nesta pesquisa;

Também agradeço profundamente ao Prof. Daniel Sant'Ana, por embarcar nesta empreitada no meio do caminho e me mostrar detalhadamente o mundo da eficiência hídrica de edifícios e a necessidade de pesquisadores dedicados a esse tema tão relevante;

Agradeço de coração ainda:

Aos professores Cláudia Amorim e Marco Antonio Souza, por terem aceitado o convite de participarem desta banca examinadora, bem como da banca de qualificação;

Aos colegas e professores da UnB, pela amizade e pelo carinho no desenvolvimento dos trabalhos que auxiliaram no referencial teórico desta pesquisa;

Aos funcionários da Secretaria de Pós-Graduação da FAU/UnB, pela atenção e cuidado no auxílio aos temas afetos à minha vida acadêmica;

Aos Prof. Marcel Bursztyn e José Drummond, do CDS/UnB, que me passaram ensinamentos de metodologia e modelagem de artigos e resenhas, que vou levar para toda minha vida;

Ao colega e Secretário de Engenharia do TCU, Eng. Sinomar Tótoli Junior, pelo grande apoio na concessão de horário especial de trabalho para a realização deste mestrado;

Aos colegas do TCU que me auxiliaram na fase final da pesquisa, em especial ao Benjamim, Lúcio e Fernando, do Comitê de Sustentabilidade; aos colegas da Secretaria de Engenharia que me ajudaram na coleta dos dados: Patrese, Joel, Geraldinho, Basílio, Tiago, Ivaldo, Antônia, entre outros; e aos colegas da Diretoria de Engenharia e da Secretaria de Relações Internacionais, que participaram do projeto piloto de 2014. 
Tudo que consegui na vida foi por meio de dedicação, perseverança e muito desejo de atingir meus objetivos, muito desejo de vitória; vitória na vida e não vitória como profissional.

Ayrton Senna (adaptado) 


\section{SUMÁRIO}

LISTA DE FIGURAS 14

LISTA DE TABELAS 15

LISTA DE QUADROS

LISTA DE GRÁFICOS

LISTA DE FOTOS 20

LISTA DE ABREVIATURAS E SIGLAS 21

RESUMO 24

ABSTRACT 25

RESUMEN 26

$\begin{array}{ll}\text { INTRODUÇÃO } & 27\end{array}$

1. Justificativa 30

2. Objetivos 33

3. Estrutura 33

CAPÍTULO 1 - GESTÃO HÍDRICA DE EDIFÍCIOS PÚBLICOS NO BRASIL 35

1.1. Ordenamento jurídico brasileiro 38

1.2. Política Nacional de Recursos Hídricos 39

1.3. CNRH e CONAMA 40

1.4. Potabilidade da água 42

1.5. Programas federais 43

1.6. Normatização 43

1.7. Legislação de estados e municípios 46

1.8. Legislação no Distrito Federal 48

1.9. Certificações e selos de eficiência hídrica 50

1.10. Caracterização do edifício de uso público administrativo 51

1.11. Construção de edifícios públicos 53

1.11.1. Licitações públicas

1.12.2. Atores envolvidos $\quad 56$

1.12. Gestão de obras públicas

1.12.1. Fase preliminar à licitação 60

1.12.2. Especificação de materiais e técnicas construtivas 60

1.12.3. Especificação de tecnologias conservadoras de água (TCAs) 61

1.12.4. Fases de contratação, execução e fiscalização $\quad 62$ 
1.13. Manutenção de edifícios públicos

1.14. Síntese analítica do capítulo $1 \quad 65$

CAPÍTULO 2 - TECNOLOGIAS CONSERVADORAS DE ÁGUA 70

2.1. Hidrometração unitária 76

2.2. Equipamentos economizadores de água (EEAs) 81

2.3. Aproveitamento de águas pluviais (AAP) 85

2.4. Uso de águas residuárias tratadas $\quad 89$

2.4.1. Tratamento de águas cinzas $\quad 91$

2.4.2. Tratamento de águas residuárias 93

2.5. Potencial de economia das TCAs 95

2.6. Síntese analítica do capítulo $2 \quad 98$

CAPÍTULO 3 - PROGRAMAS DE CONSERVAÇÃO DE ÁGUA 101

3.1. Setorização de consumo 102

3.2. Auditoria do consumo de água 103

3.3. Diagnóstico do consumo de água 106

3.4. Caracterização dos usos finais de água 106

3.5. Plano de intervenção 107

3.6. Experiência internacional 109

3.6.1. Auditoria e usos finais de água 113

3.6.2. Vazamentos e setorização da medição 115

3.6.3. Indicadores 116

3.7. Síntese analítica do capítulo $3 \quad 123$

$\begin{array}{lr}\text { CAPÍTULO } 4 \text { - METODOLOGIA } & 128\end{array}$

$\begin{array}{ll}\text { 4.1. Coleta de dados } & 130\end{array}$

4.2. Procedimentos 134

4.2.1. Sanitários e copas 134

4.2.2. Irrigação 135

4.3. Tabulação dos dados 136

$\begin{array}{ll}\text { 4.4. Análises finais } & 138\end{array}$

CAPÍTULO 5 - ESTUDO DE CASO 139

$\begin{array}{ll}\text { 5.1. Auditoria do consumo } & 139\end{array}$

5.1.1. Levantamento do conjunto edificado 140

5.1.2. Análise do consumo histórico 148

5.1.3. Sistema hidráulico e manutenção predial 156 
5.1.4. Pontos de consumo 158

5.1.4.1. Peças sanitárias 158

5.1.4.2. Irrigação 161

5.1.4.3. Limpeza 164

5.1.4.4. Cozinha do restaurante 165

5.1.4.5. Ar condicionado 168

5.1.5. Qualidade da água para consumo 169

$\begin{array}{ll}\text { 5.2. Cálculo de indicadores de consumo } & 170\end{array}$

5.3. Caracterização de usos finais de água 172

5.3.1. Política de Sustentabilidade do TCU 174

5.3.2. Aplicação de pesquisa estruturada $\quad 175$

$\begin{array}{ll}\text { 5.3.3. Resultados da pesquisa estruturada } & 176\end{array}$

$\begin{array}{ll}\text { 5.4. Diagnóstico do consumo } & 178\end{array}$

5.4.1. Equipamentos 179

5.4.2. Irrigação e limpeza 181

5.4.3. Sistema hidráulico e manutenção 182

5.4.4. Indicadores 182

5.5. Plano de intervenção 183

5.6. Síntese analítica do capítulo $5 \quad 188$

CAPÍTULO 6 - CONCLUSÕES 191

REFERÊNCIAS BIBLIOGRÁFICAS 197

$\begin{array}{ll}\text { ANEXO } 1 & 215\end{array}$

$\begin{array}{ll}\text { ANEXO } 2 & 216\end{array}$

$\begin{array}{ll}\text { ANEXO } 3 & 217\end{array}$

$\begin{array}{ll}\text { ANEXO } 4 & 218\end{array}$

$\begin{array}{ll}\text { ANEXO } 5 & 219\end{array}$

$\begin{array}{ll}\text { ANEXO } 6 & 220\end{array}$ 


\section{LISTA DE FIGURAS}

Figura 1 - Ciclo hidrológico da água

Figura 2 - Correlação entre classes de enquadramento e qualidade da água doce, de acordo com a Resolução 357/2005 do CONAMA

Figura 3 - Classes de enquadramento de usos de água doce no Brasil 42

Figura 4 - Fases das licitações públicas 54

Figura 5 - Conjunto normativo aplicado à licitação e contratação de obras públicas 56

Figura 6 - Esquema de ações para a gestão da demanda de água 73

Figura 7 - Tipos de distribuição de medição individualizada em um edifício 80

Figura 8 - Exemplo de coleta de dados remota de hidrômetros 81

Figura 9 - Esquema básico de sistema AAP 86

Figura 10 - Corte esquemático do reservatório do sistema AAP 87

$\begin{array}{lr}\text { Figura } 11 \text { - Estrutura da metodologia proposta } & 128\end{array}$

Figura 12 - Planta de implantação dos edifícios no terreno do TCU em Brasília/DF 141

Figura 13 - Planta baixa de pavimento tipo do Edifício-Sede do TCU em Brasília/DF 144

Figura 14 - Planta baixa de pavimento-tipo dos Anexos I, II e III do TCU em Brasília/DF

Figura 15 - Plantas baixas do Restaurante do TCU em Brasília/DF 


\section{LISTA DE TABELAS}

Tabela 1 - Volumes de água estimados perdidos em vazamentos 75

Tabela 2 - Relação entre equipamentos convencionais e economizadores 96

Tabela 3 - Indicadores de consumo de água para edifícios das seis principais cidades da Austrália $\left(\mathrm{m}^{3} / \mathrm{m}^{2} / \mathrm{ano}\right)$

Tabela 4 - Distribuição típica de uso de água em edifícios públicos e comerciais no Canadá em 2009

Tabela 5 - Níveis de desempenho eficiente de água para edifícios não residenciais no Reino Unido

Tabela 6 - Indicadores nacionais e internacionais de consumo de água em restaurantes

Tabela 7 - Comparação de indicadores internacionais de consumo de água em edifícios comerciais e públicos

Tabela 8 - Quantidade e proporção de usuários dos edifícios do TCU em Brasília/DF 142 Tabela 9 - Representatividade de variáveis de consumo de água no conjunto edificado do TCU em Brasília/DF

Tabela 10 - Síntese do consumo médio de água do conjunto edificado do TCU em Brasília/DF

Tabela 11 - Impacto do consumo de água do espelho d'água do Edifício Sede no consumo total do conjunto edificado do TCU em Brasília/DF

Tabela 12 - Quantitativo de peças sanitárias no conjunto edificado do TCU em Brasília/DF

Tabela 13 - Vazões médias das peças sanitárias das áreas molhadas do TCU em Brasília/DF

Tabela 14 - Informações acerca dos mictórios instalados no TCU em Brasília/DF 161

Tabela 15 - Consumo de água do sistema de irrigação do TCU em Brasília/DF

Tabela 16 - Proporcionalidade do consumo de água ao longo do ano e cálculo de indicador de consumo de água com irrigação no TCU em Brasília/DF

Tabela 17 - Representatividade do consumo da irrigação no consumo total de água no TCU em Brasília/DF

Tabela 18 - Representatividade do consumo da irrigação de cada edifício no consumo total de água no TCU em Brasília/DF 
Tabela 19 - Consumo consolidado de limpeza no conjunto edificado do TCU em Brasília/DF

Tabela 20 - Consumo de água no restaurante do TCU em Brasília/DF

Tabela 21 - Consumo de água no sistema de ar condicionado do TCU em Brasília/DF

Tabela 22 - Lista consolidada dos indicadores dos edifícios do TCU em Brasília/DF 171

Tabela 23 - Síntese dos resultados de teste piloto no Anexo III do TCU em Brasília/DF

Tabela 24 - Dados de distribuição das respostas da pesquisa de usos finais de água no TCU em Brasília/DF

Tabela 25 - Resultados finais consolidados da pesquisa de usos finais de água nas dependências do TCU em Brasília/DF

Tabela 26 - Vazões de peças sanitárias utilizadas no TCU em Brasília/DF comparadas com as informações dos fabricantes

Tabela 27 - Resumo dos indicadores de consumo de água dos equipamentos e sistemas do TCU em Brasília/DF

Tabela 28 - Comparativo de resultados da auditoria de usos finais de água do TCU em Brasília/DF com outras pesquisas 


\section{LISTA DE QUADROS}

Quadro 1 - Modalidades de reúso, segundo a Resolução CNRH 54/2005 40

Quadro 2 - Modalidades de reúso, segundo a Resolução CNRH 54/2005 41

Quadro 3 - Classes e utilizações das águas de reúso 44

Quadro 4 - Normas técnicas de uso de água correlatas à NBR 13969 e NBR $15527 \quad 45$

Quadro 5 - Exemplos de legislação municipal de conservação de água 47

Quadro 6 - Leis relativas à conservação de água no Distrito Federal 49

Quadro 7 - Exemplos de selos e certificações de edifícios com enfoque em eficiência energética e respectivo peso das ações de eficiência hídrica na nota final 50

Quadro 8 - Exemplos de selos e certificações de edifícios com enfoque em eficiência hídrica $\quad 51$

Quadro 9 - Possíveis problemas de gestão de TCAs em edifícios públicos 55

Quadro 10 - Características e responsabilidades de atores internos e externos envolvidos na construção de edifícios públicos $\quad 57$

Quadro 11 - Diferença entre similaridade e equivalência de materiais 61

Quadro 12 - Tipos de manutenção preditiva e suas características principais $\quad 64$

Quadro 13 - Exemplos de normatização internacional de hidrometração unitária 77

Quadro 14 - Exemplos de legislação municipal e estadual com obrigatoriedade de $\begin{array}{ll}\text { hidrometração individual em edifícios } & 78\end{array}$

Quadro 15 - Equipamentos economizadores de água 83

Quadro 16 - Equipamentos economizadores de baixa utilização em edifícios públicos $\quad 84$

Quadro 17 - Formas de uso de águas tratadas e suas características 91

Quadro 18 - Código de cores dos efluentes de um sistema de esgotamento sanitário $\quad 91$

Quadro 19 - Ações de um Programa de Conservação de Água 102

Quadro 20 - Exemplos de fontes alternativas de água 105

Quadro 21 - Tipos de ações de um plano de intervenção de um PCA 108

Quadro 22 - Detalhamento das áreas-chave (Key Result Areas) dos planos de gestão de água na Austrália 112

Quadro 23 - Passos de um Plano de Eficiência da Água na Carolina do Norte (EUA) 113

Quadro 24 - Etapas de uma auditoria de água na Colômbia 114

Quadro 25 - Componentes-chave e indicadores sugeridos em auditorias de água na Índia 
Quadro 26 - Parâmetros de desempenho no consumo de água para edifícios públicos e comerciais em alguns países

Quadro 27 - Perfis dos usuários de edifícios públicos e características das questões abordadas em auditorias de água

Quadro 28 - Atividades de manutenção hidráulica preventiva no TCU em Brasília/DF

Quadro 29 - Metas, expectativas e reduções de consumo de água em virtude de ações sugeridas no plano de intervenção 


\section{LISTA DE GRÁFICOS}

Gráfico 1 - Consumo de água em edifícios públicos federais dos EUA (galões/dia)

Gráfico 2 - Representatividade dos edifícios do TCU adotada na pesquisa

Gráfico 3 - Variação do reajuste de tarifas de água no conjunto edificado do TCU em Brasília/DF

Gráfico 4 - Dados climatológicos comparados com o consumo mensal do Edifício-Sede do TCU em Brasília/DF (período de 2009 a 2014)

Gráfico 5 - Dados climatológicos comparados com o consumo mensal dos Anexos I, II e Restaurante do TCU em Brasília/DF (período de 2009 a 2014)

Gráfico 6 - Dados climatológicos comparados com o consumo mensal do Anexo III do TCU em Brasília/DF (período de 2012 a 2014)

Gráfico 7 - Dados climatológicos comparados com o consumo mensal sem irrigação do Edifício-Sede do TCU em Brasília/DF (período de 2009 a 2014)

Gráfico 8 - Dados climatológicos comparados com o consumo mensal sem irrigação dos Anexos I, II e Restaurante do TCU em Brasília/DF (período de 2009 a 2014)

Gráfico 9 - Dados de temperatura ambiente comparados com o consumo mensal dos Anexos I, II e Restaurante do TCU em Brasília/DF (período de 2009 a 2014)

Gráfico 10 - Representatividade dos usos finais do teste piloto do Anexo III do TCU em Brasília/DF

Gráfico 11 - Representatividade dos usos finais do teste piloto dos equipamentos do Anexo III do TCU em Brasília/DF

Gráfico 12 - Representatividade dos usos finais de água dos equipamentos instalados nos edifícios do TCU em Brasília/DF

Gráfico 13 - Usos finais de água nos edifícios do TCU em Brasília/DF 177

Gráfico 14 - Usos finais de água de todo o conjunto edificado do TCU em Brasília/DF 


\section{LISTA DE FOTOS}

Foto 1 - Detector eletrônico de fugas d'água 74

Foto 2 - Exemplo de hidrometração unitária instalada 79

Foto 3 - Exemplo de data logger de vazão e pressão 130

Foto 4 - Recipiente padrão e procedimento para cálculo de vazão de água em torneiras 135

Foto 5 - Vista aérea e parcial do conjunto edificado do TCU em Brasília/DF 141

Foto 6 - Espelhos d'água superior (em manutenção) e jardins externos e internos do TCU em

Brasília/DF 144

Foto 7 - Peças sanitárias do Edifício-Sede do TCU em Brasília/DF 145

Foto 8 - Vistas externas dos Anexos do TCU em Brasília/DF 146

Foto 9 - Peças sanitárias e das copas dos Anexos I, II, III e Restaurante do TCU em Brasília/DF 146

Foto 10 - Áreas de trabalho na cozinha industrial do Restaurante do TCU em Brasília/DF 148

Foto 11 - Ambiente externo e interno do Restaurante do TCU em Brasília/DF 148

Foto 12 - Mecânica interna dos sensores de presença dos mictórios usados no TCU 160

Foto 13 - Exemplo de desperdício de água no TCU em Brasília/DF 163 


\section{LISTA DE ABREVIATURAS E SIGLAS}

A3P - Agenda Ambiental da Administração Pública

AAP - Aproveitamento de Águas Pluviais

ABRAMAN - Associação das Empresas Brasileiras de Manutenção

ABNT - Associação Brasileira de Normas Técnicas

ANA - Agência Nacional de Águas

ANAO - Australian National Audit Office

ANQIP - Associação Nacional para a Qualidade das Instalações Prediais (Portugal)

AQUA - Alta Qualidade Ambiental

ART - Anotação de Responsabilidade Técnica

AWE - Alliance for Water Efficiency

AWWA - American Water Works Association

BMP - Best Management Practice

BOMA - Building Owners and Managers Association of Canada

BRE - Building Research Establishment

BREEAM - Building Research Establishment Environmental Assessment Methodology

CAESB - Companhia de Saneamento Ambiental do Distrito Federal

CAU - Conselho de Arquitetura e Urbanismo

CBIC - Câmara Brasileira da Indústria da Construção

CDHU - Companhia de Desenvolvimento Habitacional e Urbano de São Paulo

CGU - Controladoria Geral da União

CIRIA - Construction Industry Research and Information Association (Londres)

CLS - Comitê de Logística Sustentável (TCU)

CNRH - Conselho Nacional de Recursos Hídricos

CONAMA - Conselho Nacional do Meio Ambiente

COPASA - Companhia de Saneamento de Minas Gerais

CPIC - Cadeia Produtiva da Indústria da Construção

CREA - Conselho Regional de Engenharia e Agronomia

DTA - Documento Técnico de Apoio

EBC - Empresa Brasileira de Comunicação

EEA - Equipamento Economizador de Água

ENAP - Escola Nacional de Administração Pública

EPA - United States Environmental Protection Agency

ETE - Estação de Tratamento de Esgotos 
EUA - Estados Unidos da América

IBAMA - Instituto Brasileiro do Meio Ambiente

IBGE - Instituto Brasileiro de Geografia e Estatística

IC - Indicador de Consumo

IN - Instrução Normativa

INMET - Instituto Nacional de Meteorologia

INMETRO - Instituto Nacional de Metrologia, Qualidade e Tecnologia

IPEA - Instituto de Pesquisas Econômicas Aplicadas

ISA - Interoperability Solutions for European Public Administration

KRA - Key Result Area

LEED - Leadership in Energy \& Environmental Design

MBR - Membrane Bioreactor

mca - metros de coluna d'água

MCTI - Ministério da Ciência, Tecnologia e Inovação

MG - Estado de Minas Gerais

MMA - Ministério do Meio Ambiente

MPOG - Ministério do Planejamento, Orçamento e Gestão

MS - Ministério da Saúde

NABERS - National Australian Built Environment Rating System

NBR - Norma Brasileira

ONU - Organização das Nações Unidas

PCA - Programa de Conservação de Água

PGR - Procuradoria Geral da República

PIB - Produto Interno Bruto

PL - Projeto de Lei

PLC - Projeto de Lei Complementar

PLS - Programa de Logística Sustentável

PNCDA - Plano Nacional de Combate ao Desperdício de Água

PNE - Portador de Necessidades Especiais

PNEUA - Plano Nacional para o Uso Eficiente da Água

PNMA - Política Nacional do Meio Ambiente

PNRH - Política nacional de Recursos Hídricos

PRFV - Plástico Reforçado com Fibra de Vidro

PROCEL - Programa Nacional de Conservação de Energia Elétrica 
PSUS/TCU - Política Institucional de Sustentabilidade do Tribunal de Contas da União PVC - Policloreto de Vinila

PURA/USP - Programa de Uso Racional de Água da Universidade de São Paulo PURAE - Programa de Conservação e Uso Racional da Água nas Edificações (Curitiba/PR)

RAFA - Reator Anaeróbio de Fluxo Ascendente

RBC - Reator Biológico de Contato

$\mathrm{rpm}$ - rotações por minuto

RRT - Registro de Responsabilidade Técnica

SABESP - Companhia de Saneamento Básico do Estado de São Paulo

SEAP - Secretaria de Estado da Administração e Patrimônio

SIAPE - Sistema Integrado de Administração de Recursos Humanos

SINDUSCON-SP - Sindicato da Indústria da Construção do Estado de São Paulo

SINGERH - Sistema Nacional de Gerenciamento de Recursos Hídricos

SLTI (MPOG) - Secretaria de Logística e Tecnologia da Informação

SRH (MMA) - Secretaria de Recursos Hídricos

TAC - Tratamento de Águas Cinzas

TAR - Tratamento de Águas Residuárias

TCA - Tecnologia Conservadora de Água

TCU - Tribunal de Contas da União

UASB - Upflow Anaerobic Sludge Blanket

UK - United Kingdom

USGBC - United States Green Building Council

USP - Universidade de São Paulo

UNESCO - United Nations Educational, Scientific and Cultural Organization

VDR - Válvula de Descarga Reduzida

VRF - Variable Refrigerant Flow

WELS - Water Efficiency Labelling and Standards 


\section{RESUMO}

A Cadeia Produtiva da Indústria da Construção tem a administração pública como um de seus mais importantes pilares, especialmente devido ao volume de contratações de obras públicas. A proporcionalidade dessa tipologia de edificação é acima da média na cidade de Brasília/DF, por se tratar da capital do Brasil e concentrar muitos órgãos federais e do Distrito Federal. Nos últimos anos, o Governo Federal tem publicado normativos que estimulam os gestores públicos a utilizar sistemas e tecnologias que priorizem a sustentabilidade e a proteção do meio ambiente. Nesse sentido, as Tecnologias Conservadoras de Água (TCAs) vêm contribuir para a viabilização dos chamados Programas de Conservação de Água (PCAs), cujas orientações para sua execução são disponibilizadas por publicações da Agência Nacional de Águas (2005) e do Ministério do Meio Ambiente (2014). O principal objetivo desta pesquisa é propor recomendações para a aplicação de PCAs, de forma a contribuir para a gestão da água em edifícios públicos administrativos. Baseado em uma revisão de literatura acerca da gestão hídrica no Brasil, da legislação pública sobre o assunto e das TCAs existentes no mercado, um estudo de caso foi desenvolvido no Tribunal de Contas da União (TCU), no qual se concluiu que os passos metodológicos dos PCAs estão adequados, sendo recomendada a incorporação do parâmetro de consumo de água por área útil edificada, mais alinhado aos padrões internacionais. Merece destaque o cálculo dos usos finais de água do TCU, em que foram encontrados indicadores de consumo de água que podem servir como referências para outras pesquisas em edifícios públicos. Foram levantados indicadores tanto de equipamentos (descarga parcial de vasos sanitários - 6,337 litros/pessoa/dia; torneiras de lavatórios - 2,413 litros/pessoa/dia, p. ex.) quanto de sistemas (irrigação - 1,276 litros/área jardins/dia; restaurante - 47,62 litros/refeição/dia, p. ex.), bem como diferenças em relação a estudos anteriores, como, por exemplo, a frequência de acionamento de mictórios [1,564 vezes nesta pesquisa e 3,119 vezes em Proença e Ghisi (2009)] ou a representatividade do consumo total de limpeza no consumo total de água $[19,04 \%$ nesta pesquisa e 3,5\% em Kammers e Ghisi (2006)]. Também foram sugeridas ações para um futuro plano de intervenção no TCU, como o estudo de viabilidade de implantação de TCAs, hidrometração setorizada, compra de equipamentos economizadores de água, redução de altura dos espelhos d'água, irrigação automatizada dos jardins e promoção de palestras para a conscientização dos usuários.

Palavras-chave: Edifícios públicos; Programas de Conservação de Água; Usos finais de água; Indicadores de consumo de água; Tribunal de Contas da União 


\begin{abstract}
The Productive Chain of the Construction Industry has the public administration as one of its most important pillars, especially due to the volume of public works contracts. Proportionally, this building typology is above average in Brasilia/DF, as it is the capital of Brazil and concentrates many federal and state agencies. In recent years, the federal government has published regulations that encourage public managers to use systems and technologies that prioritize sustainability and environmental protection. In this sense, Water Conservation Technologies (WCTs) have been contributing to the viability of Water Conservation Plans (WCPs), whose implementation guidelines are available from National Water Agency (2005) and Environment Ministry (2014) publications. The main objective of this research is to propose recommendations for applying WCPs, in order to contribute to water management in administrative government buildings. Based on a literature review about the water management, public law and WCTs in Brazil, the study was conducted in the Federal Court of Accounts (FCA), which concluded that the methodological steps of WCPs are adequate, recommending the incorporation of water consumption parameter for built floor area, in line with international standards. It is worth noticing the FCA calculation of the final uses of water, in which water consumption indicators were found which can serve as references for further research in public buildings. Indicators were raised regarding both equipments (partial discharge toilets - 6,337 liters/person/day; sinks taps - 2,413 liters/person/day) and systems (irrigation - 1,276 liters/irrigated area/day; restaurant - 47,62 liters/dish/day, e.g.), as well as differences from previous studies, such as, for example, the frequency of urinals uses [1,564 times in this study and 3,119 times in Proenca \& Ghisi (2009)] or the representativeness of total cleaning consumption in the total water consumption $[19,04 \%$ in this study and $3,5 \%$ in Kammers \& Ghisi (2006)]. Actions were also suggested for a future intervention plan in the FCA, such as the viability study of WCTs use, water submetering, purchase of water saving equipment, reducing the height of the water blades, garden automatic irrigation and promotion of lectures to raise awareness of users.
\end{abstract}

Keywords: Public Buildings; Water Conservation Plans; Water End Uses; Water Consumption Indicators; Federal Court of Accounts 


\section{RESUMEN}

La Cadena Productiva de la Industria de la Construcción tiene la administración pública como uno de sus pilares más importantes, especialmente debido al volumen de contratos de obras públicas. Esta tipología de construcción tiene una proporcionalidad superior a la media en Brasilia/DF porque es la capital de Brasil y se concentran muchas agencias federales y municipales. En los últimos años, el gobierno federal ha publicado regulaciones que incitan a los gestores públicos a utilizar los sistemas y tecnologías que prioricen la sostenibilidad y la protección del medio ambiente. En este sentido, las Tecnologías Conservadoras del Agua (TCAs) han contribuido a la viabilidad de los llamados Programas de Conservación del Agua (PCAs), cuyas directrices de aplicación están disponibles en las publicaciones de la Agencia Nacional de las Aguas (2005) y del Ministerio del Medio Ambiente (2014). El objetivo principal de este estudio es proponer recomendaciones para la aplicación del PCA, con el fin de contribuir a la gestión del agua en los edificios gubernamentales administrativos. Basado en una revisión de la literatura acerca de la gestión del agua en Brasil, de la legislación pública sobre el asunto y de las TCAs existentes en el mercado, el estudio se llevó a cabo en el Tribunal de Cuentas de la Unión (TCU), donde recomendaron la incorporación de parámetros de consumo de agua por el área de oficinas, en línea con los estándares internacionales. También es destacable el cálculo de los usos finales de agua del TCU donde se encontraron indicadores de consumo de agua que pueden servir como referencia para futuras investigaciones en los edificios públicos. Los indicadores se plantearon tanto en equipos (inodoros de descarga parcial - 6,337 litros/persona/día; grifos de lavabos - 2,413 litros/persona/día, por ejemplo) como en los sistemas (1,276 litros/área de jardines/día; restaurante - 47,62 litros/plato/día, por ejemplo), así como las diferencias de los estudios anteriores, como, por ejemplo, la frecuencia de accionamiento de los urinales [1,564 veces en este estudio y 3,119 veces en Proença y Ghisi (2009)] o la representatividad del consumo de limpieza en el consumo total de agua $[19,04 \%$ en este estudio y 3,5\% en Kammers y Ghisi (2006)]. Fueron sugeridas acciones para un futuro plan de intervención en TCU, como el estudio de viabilidad para implementación de TCAs, medición sectorizado, compra de equipos de ahorro de agua, reducción de la altura de los espejos de agua, irrigación automática de los jardines y promoción de conferencias para concienciación de los usuarios.

Palabras clave: Edificios Públicos; Programas de Conservación del Agua; Usos Finales del Agua; Indicadores de Consumo del Agua; Tribunal de Cuentas de la Unión 


\section{INTRODUÇÃO}

Historicamente, a importância da gestão do uso da água, em território brasileiro, foi um assunto pouco abordado pelos consumidores. Como havia grande oferta deste insumo nos lares e ambientes de trabalho e de lazer, a população brasileira não se preocupava em reduzir essa demanda. Hoje, a escassez da oferta se tornou assunto prioritário, visto que impactou diretamente o dia a dia dos usuários, provocando, tanto no Brasil quanto em algumas outras regiões do mundo, mudanças de hábitos de consumo.

A Organização das Nações Unidas - ONU (2010) declarou que o acesso à água potável e ao tratamento de esgotos é um direito humano. A totalidade de água considerada potável representa apenas $2,5 \%$ da água do planeta, reduzindo-se a 0,3\% a parcela disponível para consumo, presente nos lagos e rios (SHIKLOMANOV, 1993).

Na Conferência Rio+20, realizada em 2012, as nações participantes reconheceram que a água está no cerne do desenvolvimento sustentável, pois está intimamente ligada a uma série de importantes desafios globais. Entre eles está a redução pela metade, até 2015, da proporção de pessoas sem acesso à água potável e ao saneamento básico, assim como a elaboração de planos integrados de gestão e de uso eficaz dos recursos hídricos, assegurando o uso sustentável da água (ONU - ORGANIZAÇÃO DAS NAÇÕES UNIDAS, 2012).

Os representantes dos países participantes da Conferência Rio+20 sublinharam ainda a necessidade de adotar medidas para enfrentar enchentes, secas e escassez de água, mantendo o equilíbrio entre oferta e demanda de água, incluindo, quando necessário, recursos não convencionais de água, mobilizando recursos financeiros e investimento na infraestrutura de serviços de água e saneamento, de acordo com as prioridades nacionais.

No cenário internacional, o Brasil é considerado um país rico quanto à oferta de água, mas onde não se sabe utilizá-la de forma a privilegiar o desenvolvimento sustentável. Dados do Ministério das Cidades (2014), relativos ao ano de 2013, mostram que nosso índice de perdas na distribuição de água potável chega aos $37 \%$ do total ofertado. No Distrito Federal, esse índice cai para 27,3\%. O Poder Público tem adotado planos setoriais que indicam um caminho de mudança, levando ainda algum tempo para que haja um reflexo nos índices supracitados.

Recentemente, a economia de água no Brasil tornou-se um assunto prioritário, especialmente devido à carência de oferta em cidades populosas como São Paulo e Rio de Janeiro. Eventos climáticos atípicos e a falta de planejamento em longo prazo de políticas públicas de 
gerenciamento de recursos hídricos são apontados como as principais causas desse cenário. Não obstante esta situação, a demanda no país, segundo o Ministério das Cidades (2014), continua a aumentar, com um incremento de $0,5 \%$ em 2013 em relação aos últimos três anos.

Na Política Nacional de Recursos Hídricos (1997), uma das prioridades elencadas pelo Governo Brasileiro é a do incremento da gestão da oferta, da ampliação, da racionalização e do reúso de água. Dentre as ações desta política, destaca-se o apoio à edição de diretrizes e normas para estímulo e efetivação do reúso para diversas atividades econômicas.

A Estratégia Nacional de Ciência, Tecnologia e Inovação 2012-2015 (MCTI, 2012) afirma que o desenvolvimento de tecnologias que reduzam os custos de instalação e aumentem a eficiência de redes de água e saneamento em aglomerados urbanos constitui uma importante iniciativa. Ela é fundamental para desenvolver e difundir tecnologias que contribuam para que as cidades sejam economicamente viáveis, socialmente justas e ambientalmente sustentáveis.

O setor da construção civil se caracteriza por uma relevância ímpar quanto aos impactos socioambientais no perfil populacional brasileiro. Dados da Câmara Brasileira da Indústria da Construção - CBIC (2013) indicam que a construção civil tem um peso de 5,7\% de todo o PIB brasileiro, bem como representa uma fatia de 7,12\% da população economicamente ativa. É uma indústria que passa por mudanças que refletem um irreversível cenário, que, aos poucos, vem se caracterizando pela quebra de paradigmas quanto à responsabilidade socioambiental.

Em recente pesquisa de mercado, a CBIC (2012) afirmou que 90\% das empresas do ramo têm buscado novos processos construtivos. Gestores públicos e privados têm assumido a responsabilidade de assegurar o desempenho ambiental de construções. No que concerne à água, esse desempenho pressupõe a gestão eficiente deste insumo, por meio de ações ao longo do ciclo de vida do edifício, dentro do intervalo que vai desde a concepção do projeto até a sua manutenção.

Em muitos países, especialmente os da Europa, além de Austrália, Nova Zelândia, EUA, Canadá e Índia, percebe-se também uma preocupação com o estabelecimento de regras específicas para a conservação de água em edifícios públicos. Tais regras sempre passam pelo desenvolvimento de um programa ou plano de conservação de água.

Registra-se que houve uma evolução dos conceitos de uso de água em edificações ao longo do tempo. Atuando apenas na demanda, o discurso anterior era o de uso racional da água, pela 
busca do menor consumo possível, mantidas, em qualidade e quantidade, as atividades consumidoras. O novo conceito refere-se à conservação de água, que prima pela otimização do consumo aliada ao uso de fontes alternativas para um abastecimento descentralizado, por meio de sistemas prediais de água não potável, empregando água "menos nobre" para fins "menos nobres", possibilitando a aplicação de um novo enfoque de gestão, que possa atuar tanto na demanda quanto na oferta de água (GONÇALVES, 2007).

Na gestão da utilização da água de um edifício, fundamental para estabelecer o equilíbrio entre oferta e demanda, é necessário que métodos e sistemas alternativos modernos sejam corretamente aplicados. Em edifícios públicos, a gestão se inicia na fase de desenvolvimento de projetos, seguindo rigorosamente o que determina a Lei $n^{\circ}$ 8666/1993, a Lei de Licitações Públicas, completando-se na definição dos procedimentos de manutenção predial, de forma que os sistemas e equipamentos implantados funcionem com eficiência e pelo maior tempo possível, com redução de perdas e minimização da geração de efluentes.

Uma ferramenta recomendada para a execução adequada desta gestão de água em edifícios é o Programa de Conservação de Água (PCA), que, segundo documento orientativo da Agência Nacional de Águas (ANA), é definido como "o conjunto de ações voltadas para a gestão da oferta e da demanda de água em edificações" (ANA et al., 2005). Os PCAs tiveram origem no Brasil nos estudos de Oliveira e Gonçalves (1999) e são utilizados em pesquisas de edifícios diversos, como residenciais, comerciais, industriais e públicos.

Como consequência da necessidade deste aprimoramento de gestão, recomendado por ANA et al. (2005) e ratificado pelo MMA (2014), vem se consolidando no mercado brasileiro o uso de materiais e sistemas que primam pela economia de água, que se denominam nesta pesquisa Tecnologias Conservadoras de Água (TCAs).

Estão inclusos nesse grupo a hidrometração unitária, o uso de equipamentos economizadores de água, a aplicação dos sistemas de aproveitamento de águas pluviais e o uso de águas cinzas e residuárias. As soluções na área de TCAs em edifícios pressupõem um mínimo conhecimento técnico de instalações de água potável, drenagem de águas pluviais e tratamento de águas residuárias.

No setor público, esse conhecimento perpassa todo o processo construtivo de edifícios, destacando-se o papel dos especificadores, fiscalizadores e executores das obras, que, em 
conjunto, atuam como disseminadores da importância da relação da obra com o meio ambiente e da economia da água para esta e futuras gerações.

A mudança de postura dos atores públicos envolvidos nesse processo tem acontecido de forma lenta, muitas vezes reflexo da desinformação e desinteresse de profissionais e do reduzido número de políticas públicas adotadas pelos governos em todas suas esferas. As leis existentes ainda são muito genéricas e pouco disseminadas, não atingindo de forma prática os usuários do sistema, pois não dispõem de instrumentos objetivos de controle, que efetivamente levem a uma mudança de postura da população.

Segundo Bursztyn (2001), no cenário das políticas públicas voltadas para o meio ambiente, a distância entre as leis e a realidade é inconfundível. O autor acrescenta que, em quase todas as nações, inclusive naquelas em que a legislação se aplica com determinação, os resultados não são de todo satisfatórios. Portanto, há que se identificarem claramente as políticas públicas mais adequadas para cada caso, para que o resultado das ações do governo não esteja fadado ao rótulo do "faz de contas".

Não obstante este quadro, uma das ações efetivas do Governo Federal foi a publicação da Instrução Normativa $n^{\circ}$ 2/2014, da Secretaria de Logística e Tecnologia da Informação do Ministério do Planejamento, Orçamento e Gestão (SLTI/MPOG), que obrigou os edifícios públicos novos, assim como as reformas dos existentes, a implantarem soluções de eficiência que os capacite a receber a etiqueta do programa Procel Edifica na categoria "A". Esta etiqueta é voltada para a eficiência energética, mas traz critérios e bonificações importantes no quesito de uso de TCAs.

Cabe ressaltar que, nesta pesquisa, a conservação de água em edifícios sempre pressupõe a eficiência do seu uso e a viabilidade econômica como uma condição para a tomada de decisões em nível gerencial, estabelecimento de metas e definição de ações, associando a menor quantidade à melhor qualidade possível, por meio de TCAs, mantendo-se a segurança, a saúde e o conforto no momento do uso.

\section{Justificativa}

As construções públicas representam uma parcela significativa do universo da cadeia produtiva da indústria da construção (CPIC). Segundo o IBGE (2014), 35\% do total das construções executadas em 2012 vieram de obras contratadas por entidades públicas. Apesar do quadro de instabilidade da economia em 2015 e do impacto no setor da construção civil, 
historicamente, este setor, juntamente com o agropecuário, destaca-se na composição do PIB nacional ${ }^{1}$.

O setor público pode, portanto, com instrumentos adequados, provocar a disseminação de tecnologias que aliem inovação e custo competitivo de implantação e manutenção. Cabe considerar também que o serviço público exerce um papel de destaque como cliente da cadeia produtiva da indústria da construção (CPIC), fomentando discussões, motivando a busca de inovação na indústria brasileira e atraindo investimentos por meio de parcerias públicoprivadas e agências de fomento, movimentando um importante setor econômico no cenário nacional. Esta pesquisa, portanto, também se justifica pela grande força que o Poder Público exerce como potencial berço de novas tecnologias, de ideias inovadoras e de mudanças de paradigmas na construção civil.

Com processos atrelados a uma lei licitatória publicada há 27 anos, a decisão dos gestores públicos na definição das metas e políticas públicas dos respectivos órgãos ocorre, na maioria dos casos, com o preço se sobressaindo em relação à qualidade. Baixos custos, sem outras condições associadas, recorrentemente refletem-se em baixa qualidade de serviços. Exigências como as definidas nas INs $n^{\circ} 2$ (2014) e no 10 (2012), ambas da SLTI/MPOG, vão forçar gestores a rever seus conceitos de gestão, focando mais no aspecto ambiental. No escopo de conservação de água em edifícios públicos, existem ações em que o investimento é baixo para um resultado praticamente imediato.

A IN 10/2012 SLTI/MPOG estabelece, em seu artigo 5ª que os Planos de Gestão de Logística Sustentável, exigidos pelo Decreto Federal no 7.746/2012, deverão conter, no mínimo:

- Atualização do inventário de bens e materiais do órgão ou entidade e identificação de similares de menor impacto ambiental para substituição;

- Práticas de sustentabilidade e de racionalização do uso de materiais e serviços;

- Responsabilidades, metodologia de implementação e avaliação do plano; e

- Ações de divulgação, conscientização e capacitação.

Entre as práticas de sustentabilidade e racionalização do uso de materiais exigidos por essa regra, estão algumas vinculadas ao uso da água e tratamento do esgoto dos edifícios (art. $8^{\circ}$, III). O conteúdo supracitado assemelha-se às recomendações da ANA et al. (2005), que definem ações de conservação de água como todas aquelas que: a) reduzam a quantidade de

\footnotetext{
${ }^{1}$ A taxa de crescimento nacional do PIB em 2013, por exemplo, foi de 2,7\%, enquanto que o setor da construção civil subiu 4,7\%. No ano de 2014, a situação se inverteu, com o PIB nacional se mantendo estável $(0,1 \%)$ e com um decréscimo de $2,6 \%$ no setor da construção civil.
} 
água extraída em fontes de suprimento; b) reduzam o consumo de água; c) reduzam o desperdício de água; d) aumentem a eficiência do uso de água; e e) aumentem a reciclagem e o reúso de água.

As publicações de ANA et al. (2005) e do Ministério do Meio Ambiente - MMA (2014) recomendam que os Programas de Conservação de Água (PCAs) sigam um rito, uma sequência, que inclui, essencialmente, uma auditoria do consumo de água, com consequente montagem de um diagnóstico deste consumo, identificando os sistemas que contribuem para o volume de água consumido naquele momento. Após esta fase, deve ser elaborado um plano de intervenção, que deverá conter sugestões de ações para redução do consumo. Recomendase, no mesmo momento, que se faça uma avaliação preliminar do impacto de redução de consumo. Optando-se por implementar o PCA, cabe ao sistema de gestão do edifício o monitoramento dos indicadores de consumo e eventual revisão do programa, se necessário.

A mais recente regulamentação nesta área foi a publicação da Portaria $n^{\circ} 23$ do MPOG (2015), na qual o Poder Executivo determinou o monitoramento de consumo de energia e água de todos os órgãos, por meio da inserção mensal de informações de consumo em um banco de dados. Dessa forma, será possível acompanhar os órgãos públicos que possuam indicadores de consumo acima da média, atuando diretamente na sua gestão.

Ainda são poucos os estudos que procuram caracterizar e identificar potenciais para modificar o padrão de uso final de água, reduzindo desperdícios ou introduzindo equipamentos mais eficientes ao sistema (GONÇALVES, 2009). A literatura que trata do tema é referenciada predominantemente a edifícios comerciais [Silva (2007); Proença \& Ghisi (2009); Alves (2010) e Lage (2010)] ou residenciais [Rocha et al. (1998); Oliveira (2002); Morelli (2005) e Leuck (2008)]. Há também trabalhos que tratam de edifícios institucionais em campi universitários [Silva et al. (2006) e Almeida (2009)] ou de edifícios escolares [Hernandes (2006); Silva (2007) e Marinoski \& Ghisi (2008)], entre outras tipologias.

A única pesquisa encontrada que trata especificamente de usos finais em edifícios públicos foi desenvolvida por Kammers \& Ghisi (2006), que apresentou resultados acerca dos usos finais de água estimados para dez edifícios do setor público localizados em Florianópolis/SC. É evidente que há necessidade de se avançar nas pesquisas para se traduzir em números o comportamento do usuário no consumo de água desse tipo de edifícios. 
Diante desse cenário, faz-se necessário propor recomendações e orientações a gestores públicos no que tange à aplicação de PCAs em edifícios públicos, analisando as orientações da Agência Nacional de Águas (ANA) e dos Ministérios do Planejamento, Orçamento e Gestão (MPOG) e do Meio Ambiente (MMA), avaliando também a possibilidade de aplicação de práticas internacionais.

A partir deste estudo, parte-se da hipótese de que a legislação vigente, as práticas de gestão pública e as orientações dos órgãos públicos supracitados têm lacunas suficientes para propor recomendações de ajustes. Outra hipótese levantada é de que haverá elementos suficientes no estudo de caso para a elaboração de um diagnóstico de consumo de água e seu respectivo plano de intervenção.

\section{Objetivos}

O objetivo geral desta pesquisa é propor recomendações para a aplicação de Programas de Conservação de Água (PCAs), de forma a contribuir para a gestão da água em edifícios públicos administrativos, por meio de realização de diagnóstico de consumo de água em estudo de caso em Brasília/DF.

Os objetivos específicos são:

- Analisar a gestão de água e instrumentos legais e normativos em edifícios públicos administrativos no contexto brasileiro, recomendando ajustes pontuais;

- Caracterizar as tecnologias conservadoras de água (TCAs) disponíveis no Brasil, especialmente o uso de equipamentos economizadores de água, o aproveitamento de águas pluviais e o uso de tecnologias de tratamento de águas cinzas e residuárias;

- Levantar as práticas consolidadas de PCAs no cenário internacional e, se necessário, propor ajustes às recomendações utilizadas na literatura brasileira;

- Realizar diagnóstico de consumo de água no conjunto edificado do Tribunal de Contas da União (TCU) em Brasília/DF, indicando medidas e verificando os benefícios potenciais em futuras ações de conservação de água.

\section{Estrutura}

A dissertação está dividida em cinco capítulos: o primeiro capítulo traz um panorama da situação hídrica, legislação e normatização gerais, programas de conservação de água potável e a implantação de políticas públicas brasileiras. Também aborda informações acerca dos edifícios públicos administrativos, suas características físicas, os modelos de gestão 
existentes, os atores envolvidos no processo, as fases de projeto, fiscalização, execução e manutenção de obras públicas.

O segundo capítulo exemplifica os diversos tipos de TCAs existentes, vantagens e desvantagens de cada uma, aplicabilidade à realidade dos edifícios públicos e características técnicas de execução.

O terceiro capítulo trata da metodologia da pesquisa, detalhando os passos e a estruturação do método proposto, as sistemáticas aplicáveis e os resultados esperados. Também são abordadas as características dos PCAs ao redor do mundo, comparando com os métodos utilizados no Brasil. No mesmo capítulo, são explicitados os modelos adotados no estudo de caso escolhido na pesquisa e nos questionários aplicados em edifícios públicos.

O quarto capítulo detalha os resultados obtidos no estudo de caso, o conjunto edificado do TCU em Brasília/DF. O quinto capítulo é reservado para as análises finais dos resultados obtidos, definindo as recomendações para aperfeiçoar e estimular o desenvolvimento de PCAs em edifícios públicos administrativos do Distrito Federal, bem como para a sugestão de temas de futuras pesquisas. 


\section{CAPÍTULO 1 - GESTÃo HÍDRICA DE EDIFÍCIOS PÚBLICOS NO BRASIL}

A água é uma fonte vital para a vida humana no planeta e um recurso indispensável para a economia. Ela é disponibilizada onde a natureza determina e não necessariamente onde precisamos e nem na quantidade que queremos.

A presença ou ausência de água pode significar a vida ou a morte, a prosperidade ou a pobreza. A água é um bem necessário em residências e em atividades públicas, bem como sua presença é um fator crítico na produção agrícola e industrial.

A água também tem um papel fundamental na regulação do clima. $\mathrm{O}$ ciclo hidrológico na Terra ocorre quando a água está circulando nos rios e lagos, movendo-se como vapor d'água, precipitando-se como chuva ou neve, filtrando-se no solo e recarregando aquíferos, conforme exemplificado na Figura 1.

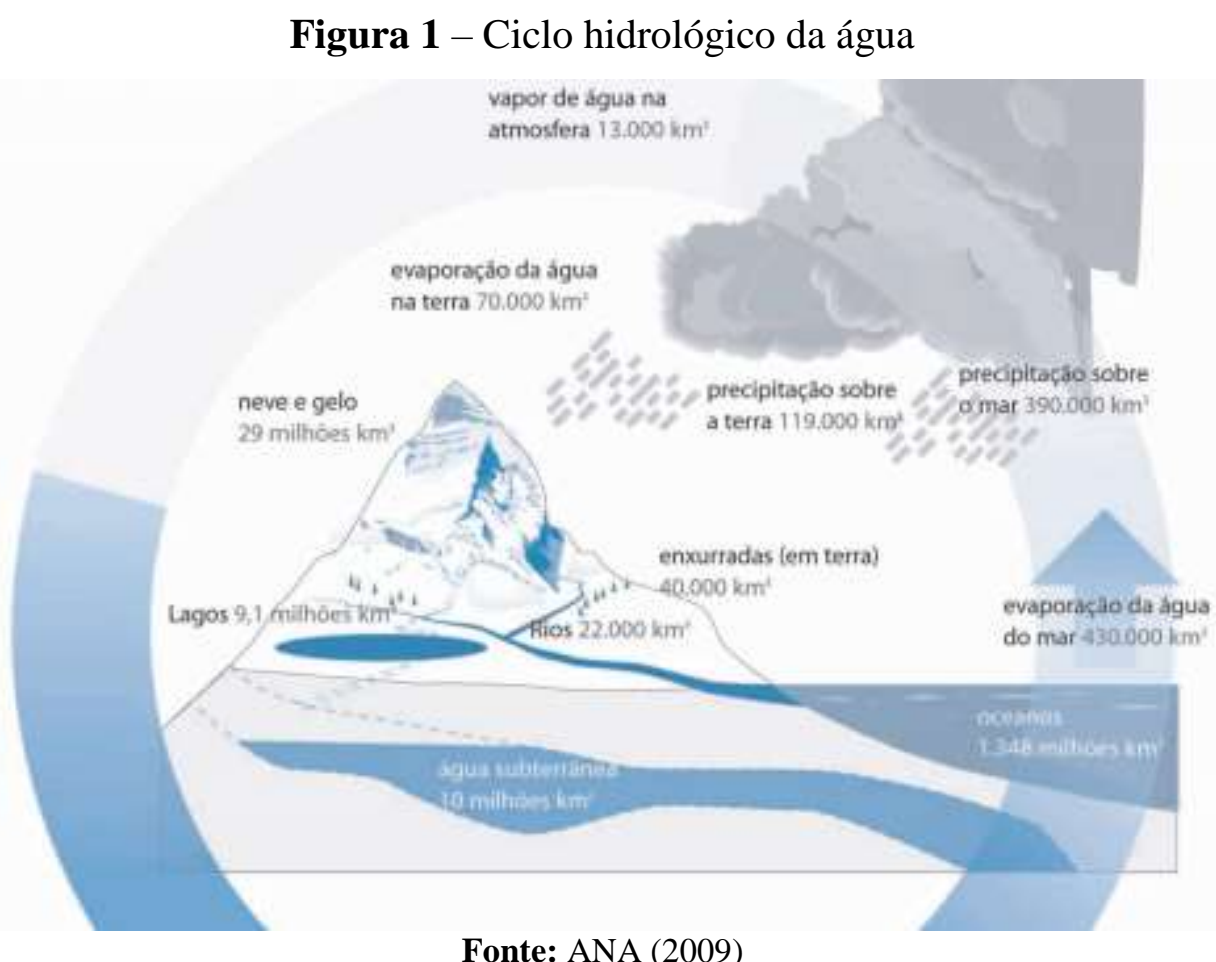

Dados levantados por Shiklomanov (1993) definem que a presença da água doce representa apenas $2,5 \%$ da água disponível no planeta, sendo $1,73 \%$ nas geleiras, $0,76 \%$ nos aquíferos e 0,009\% nos rios e lagos, totalizando um volume de cerca de 35 milhões de $\mathrm{km}^{3}$. Se esta água estivesse espalhada uniformemente sobre a superfície da Terra, faria uma camada de 70 metros de espessura. Entretanto, quase toda essa água doce é retida nas calotas de gelo da Antártida e da Groenlândia e sob aquíferos subterrâneos, que permanecem técnica ou economicamente além do alcance da população mundial. 
Segundo a ONU, em 2030 o mundo precisará de um incremento de 35\% na produção de alimentos, $40 \%$ na produção de água e 50\% na de energia (EBC, 2014). As necessidades de água serão demandadas pelo crescimento da população, pela urbanização e industrialização e pela expansão da agricultura irrigada.

Mais da metade dos rios do mundo estão seriamente comprometidos em relação à vazão e são poluídos por excesso de uso e/ou má gestão. Esta poluição inclui lançamento de dejetos humanos sem tratamento, descarga química industrial, lixiviação, vazamentos de petróleo e migração de produtos químicos agrícolas (SHIKLOMANOV, 1993).

Parte desta contaminação é proveniente da acelerada urbanização das metrópoles e proliferação de edifícios. Dentre estes, são noticiadas na mídia situações de abandono e má gestão de alguns edifícios públicos, notadamente nos casos dos mais antigos, com instalações sem manutenção ou em cidades sem infraestrutura urbana adequada.

Não há solução para todos os problemas relacionados com a escassez de água, mas é evidente que o aumento na procura por água não pode ser solucionado somente com a ampliação da oferta. Para garantir segurança no abastecimento de água e preservar os recursos hídricos para as futuras gerações, torna-se imprescindível uma gestão com controle da demanda. Conservação, reciclagem e uso eficiente deste recurso estão entre os mais relevantes investimentos do futuro, sob a ótica da sustentabilidade.

Em termos de abastecimento de água, a produção tende a avançar em direção a "zero descarga de efluentes", com a indústria e a agricultura trabalhando para converter fluxos de águas residuárias em insumos úteis para outros processos. Pelo lado da demanda, quando se trata de uso doméstico, há ainda grande preconceito da população acerca de usos não potáveis em edifícios, em parte causada pela falta de informação e de campanhas de esclarecimento.

O Brasil se caracteriza pela alta disponibilidade hídrica. Considerando a descarga média dos rios $\left(\mathrm{km}^{3} / \mathrm{ano}\right)$, destaca-se como o país mais rico do mundo, com $13 \%$ da disponibilidade mundial da água doce existente (ANA - AGÊNCIA NACIONAL DE ÁGUAS, 2015). Mais de $90 \%$ do território nacional recebe chuvas entre 1.000 e 3.000 mm/ano, com média anual de $1.797 \mathrm{~mm}$. No caso de águas subterrâneas, a disponibilidade brasileira é da ordem de 5.000 $\mathrm{m}^{3}$ per capita/ano, o que significa que cerca de $80 \%$ da população urbana brasileira poderia ser abastecida por essa fonte (ANA - AGÊNCIA NACIONAL DE ÁGUAS, 2005). 
Esta abundância dá fundamento à cultura do desperdício, provocando a redução de investimentos necessários ao seu uso e proteção e à fraca valorização econômica deste insumo. Apesar de a vazão média dos rios no Brasil ser excelente (cerca de 33.000 $\mathrm{m}^{3} /$ habitante/ano), as desigualdades regionais mostram cenários considerados críticos segundo a ONU (2014), com menos de $1.000 \mathrm{~m}$ 3/habitante/ano, na região Nordeste e em áreas populosas da região Sudeste. Falkenmark (1997) entende que, para uma autossuficiência na produção de alimentos, uma nação deverá produzir ao menos 900 m³/habitante/ano.

Desde 2012, observa-se uma constante e intensa redução nos índices pluviométricos em algumas regiões do País, prejudicando de forma significativa a oferta de água para o abastecimento público, especialmente no semiárido brasileiro e nas metrópoles com maior demanda hídrica, como São Paulo e Rio de Janeiro.

Para se ter ideia da redução, o sistema Cantareira, que abastece a região metropolitana de São Paulo, a mais populosa do Brasil, entre outubro de 2013 e fevereiro de 2014, período historicamente chuvoso, registrou uma vazão média anual igual a $8,70 \mathrm{~m}^{3} / \mathrm{s}$, que é o menor valor no histórico desde 1930. Esse valor corresponde a $22 \%$ da média anual histórica $(39,44$ $\left.\mathrm{m}^{3} / \mathrm{s}\right)$ e a $40 \%$ da vazão média de $1953(21,81 \mathrm{~m} 3 / \mathrm{s})$, que era, até então, o menor valor de vazão média anual de todos os tempos (ANA - AGÊNCIA NACIONAL DE ÁGUAS, 2015).

Segundo informações do Sistema Alerta Rio, que dá informações em tempo real das chuvas na região metropolitana do Rio de Janeiro, a média de precipitações em 2014 foi $40 \%$ menor que a média histórica desde 1997. Ainda de acordo com a ANA (2015), as causas da crise hídrica não podem ser reduzidas apenas às menores taxas pluviométricas verificadas nos últimos anos, pois outros fatores relacionados à gestão da demanda e à garantia da oferta são importantes para agravar ou atenuar sua ocorrência.

Um dos grandes desafios das regiões densamente povoadas é conter a demanda pelo consumo de água potável associado ao incremento constante da captação e preservação dos mananciais. Conforme Vargas (2013), a chamada lógica da oferta, que presidiu a abordagem hidráulica e sanitária dos diferentes usos sociais e econômicos da água, passou a ser gradualmente substituída por noções como gestão integrada, gestão sustentável, lógica da demanda e abordagem ecológica ou holística dos recursos hídricos no âmbito das bacias hidrográficas. 


\subsection{Ordenamento jurídico brasileiro}

Em qualquer sociedade minimamente organizada, as ações dos cidadãos são disciplinadas por meio de leis, regulamentos e normas. Nesses documentos estão incorporadas regras que facultam, obrigam, recomendam, direcionam e organizam entidades, grupos, regiões ou nações.

Cunha (2008) salienta que é essencial que normas, padrões e bases legais sejam estabelecidos para garantir os mínimos padrões de segurança à saúde e ao meio ambiente, impedindo o oferecimento de água contaminada por poluentes de qualquer natureza.

A legislação brasileira é uma das mais respeitadas e completas do mundo, com avanços consideráveis na gestão das águas, mesmo contando com dimensões continentais e com grande variedade de clima, adensamento populacional e disponibilidade hídrica.

A primeira legislação no Brasil a abordar o uso da água foi o Código de Águas (BRASIL, 1934), instituído pelo Decreto Federal $\mathrm{n}^{\circ}$ 24.643, que foi criado com a finalidade de estabelecer o regime jurídico das águas no Brasil, dispondo sobre sua classificação e utilização, bem como sobre o aproveitamento do potencial hidráulico. Encontram-se no Código das Águas os primeiros dispositivos legais que possibilitaram o trabalho governamental com instrumentos de gestão e com a cobrança pelo uso da água.

Com a instituição da Política Nacional de Meio Ambiente - PNMA (BRASIL, 1981), pela Lei $\mathrm{n}^{\circ}$ 6.983, e a criação do Conselho Nacional de Meio Ambiente (CONAMA), o país passou a contar com um arcabouço legal e com o ordenamento institucional necessário ao tratamento das questões ambientais.

Na promulgação da atual Constituição Federal (BRASIL, 1988), todas as águas tornaram-se públicas, posto que são bens públicos de uso comum do povo, incluindo as subterrâneas, não mais existindo águas comuns ou particulares. Assim, os antigos proprietários de poços, lagos ou qualquer outro corpo de água passaram à condição de meros detentores dos direitos de uso dos recursos hídricos, caso obtivessem a necessária outorga prevista em Lei.

No artigo 225 da Carta Magna foi previsto que "todos têm direito ao meio ambiente ecologicamente equilibrado, bem de uso comum do povo e essencial à sadia qualidade de vida, impondo-se ao Poder Público e à coletividade o dever de defendê-lo e preservá-lo para presentes e futuras gerações". Esse artigo incluiu o conceito de desenvolvimento sustentável ao ordenamento jurídico brasileiro. 


\subsection{Política Nacional de Recursos Hídricos}

Vislumbrando a necessidade de dar mais atenção à questão dos recursos hídricos, o Governo Federal, no âmbito do Ministério do Meio Ambiente, criou, no ano de 1995, a Secretaria de Recursos Hídricos (SRH), com a responsabilidade de propor a formulação da Política Nacional de Recursos Hídricos (PNRH), bem como acompanhar e monitorar sua implantação.

Dois anos depois, foi editada a Lei $n^{\circ} 9.433$ (BRASIL, 1997), que instituiu a PNRH e criou o Sistema Nacional de Gerenciamento dos Recursos Hídricos (SINGERH), regulamentando assim o inciso XIX do artigo 21 da Constituição Federal. A partir desta lei são notórios os avanços no gerenciamento e na aplicação dos instrumentos de gestão em todo o país, passando desde então a ser chamada de Lei das Águas.

Segundo a Companhia Ambiental do Estado de São Paulo - CETESB (2010), essa legislação hídrica brasileira foi inspirada no modelo francês e representa um exemplo ambicioso de gestão do uso dos rios. De acordo com a legislação, a gestão é descentralizada e participativa. Nesse modelo, as decisões sobre os usos dos rios em todo o país são tomadas pelos Comitês de Bacias Hidrográficas, que são constituídos, em igual proporção, por representantes da sociedade civil, dos estados e dos municípios.

De acordo com Senra et al. (2012), um dos pilares da PNRH é a gestão dos recursos hídricos visando aos usos múltiplos, ou seja, uso urbano, industrial, geração de energia elétrica, navegação e irrigação. Em casos de escassez, o consumo humano e a dessedentação de animais devem ser priorizados. Entende-se por consumo humano a satisfação das primeiras necessidades da vida, tais como: água para beber, preparo de alimentos e higienização.

Almeida (2011) informa que é imprescindível que haja articulação política e troca de experiências entre órgãos do governo federal, estadual e municipal, a fim de elaborarem políticas públicas integradas e complementares à $\mathrm{PNRH}$, em busca de alternativas que racionalizem o uso da água.

Com a publicação da Resolução $\mathrm{n}^{\circ} 135$ do CNRH (2011), ocorreu uma revisão geral do PNRH e a definição de ações prioritárias para o período 2012-2015. Entre os subprogramas detalhados, um específico trata da gestão da oferta, ampliação, racionalização e reúso das disponibilidades hídricas. Entre as ações sugeridas estão o(a):

- Apoio à edição de diretrizes e normas para estímulo e efetivação do reúso de água para diversas atividades econômicas; 
- Implementação de ações de reúso de efluentes tratados;

- Elaboração de estratégias para definição das diretrizes para o reúso da água;

- Elaboração de Política de Reúso da Água e Aproveitamento de Água Pluvial;

- Implantação de mecanismos de redução de desperdício e incentivo para a elevação da eficiência de uso e reúso da água nos ambientes urbanos e rurais.

Outras leis federais importantes, relacionadas ao tema de gestão pública das águas, estão resumidas no Quadro 1.

Quadro 1 - Modalidades de reúso, segundo a Resolução CNRH 54/2005

\begin{tabular}{|c|c|}
\hline Lei & Características principais \\
\hline $\begin{array}{c}\text { Lei n }^{\circ} \\
9.605 / 1998\end{array}$ & $\begin{array}{l}\text { É chamada Lei da Natureza ou Lei dos Crimes Ambientais. Seu texto declara como crime o } \\
\text { ato de causar poluição hídrica em cursos de água de abastecimento público. Também fornece } \\
\text { o incentivo decisivo para o uso de águas tratadas, quando instituiu a obrigação de se tratar os } \\
\text { efluentes. A regulamentação desta Lei quanto às sanções está no Decreto Federal n }{ }^{\circ} 6.514 \\
\text { (BRASIL, 2008) }\end{array}$ \\
\hline $\begin{array}{c}\text { Lei } \mathrm{n}^{\circ} \\
11.445 / 2007\end{array}$ & $\begin{array}{l}\text { Estabelece diretrizes nacionais de saneamento básico. Sua regulamentação se dá pelo } \\
\text { Decreto Federal nº } 7.217 \text { (BRASIL, 2010). }\end{array}$ \\
\hline $\begin{array}{c}\text { Decreto Federal } \\
n^{\circ} 7.746 / 2012\end{array}$ & $\begin{array}{l}\text { É um dos mais recentes regulamentos da administração pública e que impacta diretamente } \\
\text { nas construções públicas. Nele se estabelecem critérios, práticas e diretrizes para a promoção } \\
\text { do desenvolvimento nacional sustentável nas contratações realizadas pela administração } \\
\text { pública federal, bem como se exige dos órgãos públicos a apresentação de um Plano de } \\
\text { Gestão de Logística Sustentável. São elencadas como diretrizes de sustentabilidade, entre } \\
\text { outras: menor impacto sobre recursos naturais como flora, fauna, ar, solo e água; maior } \\
\text { eficiência na utilização de recursos naturais como água e energia; maior vida útil e menor } \\
\text { custo de manutenção do bem e da obra; uso de inovações que reduzam a pressão sobre } \\
\text { recursos naturais; e origem ambientalmente regular dos recursos naturais utilizados nos bens, } \\
\text { serviços e obras. }\end{array}$ \\
\hline
\end{tabular}

Fontes: BRASIL [(1998); (2007); (2012)]

\subsection{CNRH e CONAMA}

O Conselho Nacional de Recursos Hídricos (CNRH) é a instância máxima do SINGERH e, entre suas competências, está a análise de propostas de alteração da legislação pertinente a recursos hídricos. Dentre os instrumentos legais de sua competência, destaca-se a Resolução $\mathrm{n}^{\circ} 54$ (2005), que estabelece os critérios gerais para a prática de reúso direto não potável de água, definindo que:

- Nenhuma água de boa qualidade deverá ser utilizada em atividades que tolerem águas de qualidade inferior, pois os recursos hídricos devem ser conservados para o abastecimento público, ou para outros usos mais exigentes;

- O reúso de água constitui prática de racionalização e de conservação dos recursos hídricos, conforme os princípios estabelecidos na Agenda 21;

\footnotetext{
${ }^{2}$ Por exemplo, em seu art. 62, III, o Decreto define que causar poluição hídrica que torne necessária a interrupção do abastecimento público de água de uma comunidade pode ensejar uma multa que pode variar de cinco mil reais a cinquenta milhões de reais.
} 
- A elevação dos custos de tratamento de água é decorrente da degradação dos mananciais e, por isso, o reúso é fator redutor das descargas de poluentes em corpos receptores;

- O reúso contribui para a proteção do meio ambiente e da saúde pública.

Nessa mesma legislação categorizam-se as modalidades de reúso, por meio dos fins a que se destinam, conforme o Quadro 2.

Quadro 2 - Modalidades de reúso, segundo a Resolução CNRH 54/2005

\begin{tabular}{|c|c|}
\hline Tipo de reúso & Características \\
\hline Urbano & $\begin{array}{l}\text { Utilização de água de reúso para fins de irrigação paisagística, lavagem de logradouros } \\
\text { públicos e veículos, desobstrução de tubulações, construção civil, edificações, combate } \\
\text { a incêndio da área urbana. }\end{array}$ \\
\hline Agrícola/Florestal & Aplicação de água de reúso para produção agrícola e cultivo de florestas plantadas. \\
\hline Ambiental & $\begin{array}{c}\text { Utilização de água de reúso para implantação de projetos de recuperação do meio } \\
\text { ambiente. }\end{array}$ \\
\hline Industrial & Utilização de água de reúso em processos, atividades e operações industriais. \\
\hline Aquicultura & Utilização de água de reúso para a criação de animais ou cultivo de vegetais aquáticos. \\
\hline
\end{tabular}
Fonte: Resolução CNRH n ${ }^{\circ}$ 54/2005

A Resolução $n^{\circ} 357$ do Conselho Nacional do Meio Ambiente - CONAMA (2005), ao estabelecer as condições e os padrões de lançamento de efluentes, em seu art. 24, determinou que "os efluentes de qualquer fonte poluidora somente poderão ser lançados, direta ou indiretamente, nos corpos de água, após o devido tratamento e desde que obedeçam às condições, padrões e exigências dispostos nesta resolução".

Na edição da Resolução 357 (2005) foram criadas classes de qualidade: classes especial e classes 1 a 4 para águas doces, classes 5 e 6 para águas salinas e classes 7 e 8 para águas salobras. A Figura 3 faz a correlação entre as classes de enquadramento (especial e de 1 a 4) e os usos de água doce, destacando características específicas, notadamente no caso de consumo humano. Também é apresentada na Figura 2 uma gradação correlacionando a qualidade das águas, a exigência de usos e as classes de enquadramento.

Figura 2 - Correlação entre classes de enquadramento e qualidade da água doce, de acordo com a Resolução 357/2005 do CONAMA

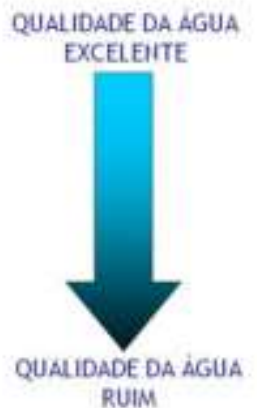

RUIM

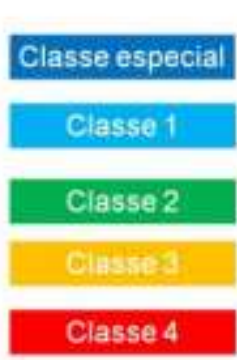

Fonte: ANA (2014)

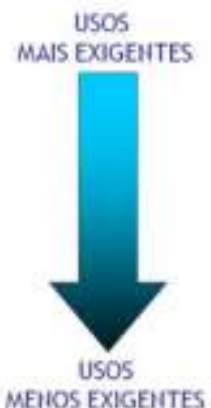

MERIOS EXIGEITES 
Figura 3 - Classes de enquadramento de usos de água doce no Brasil

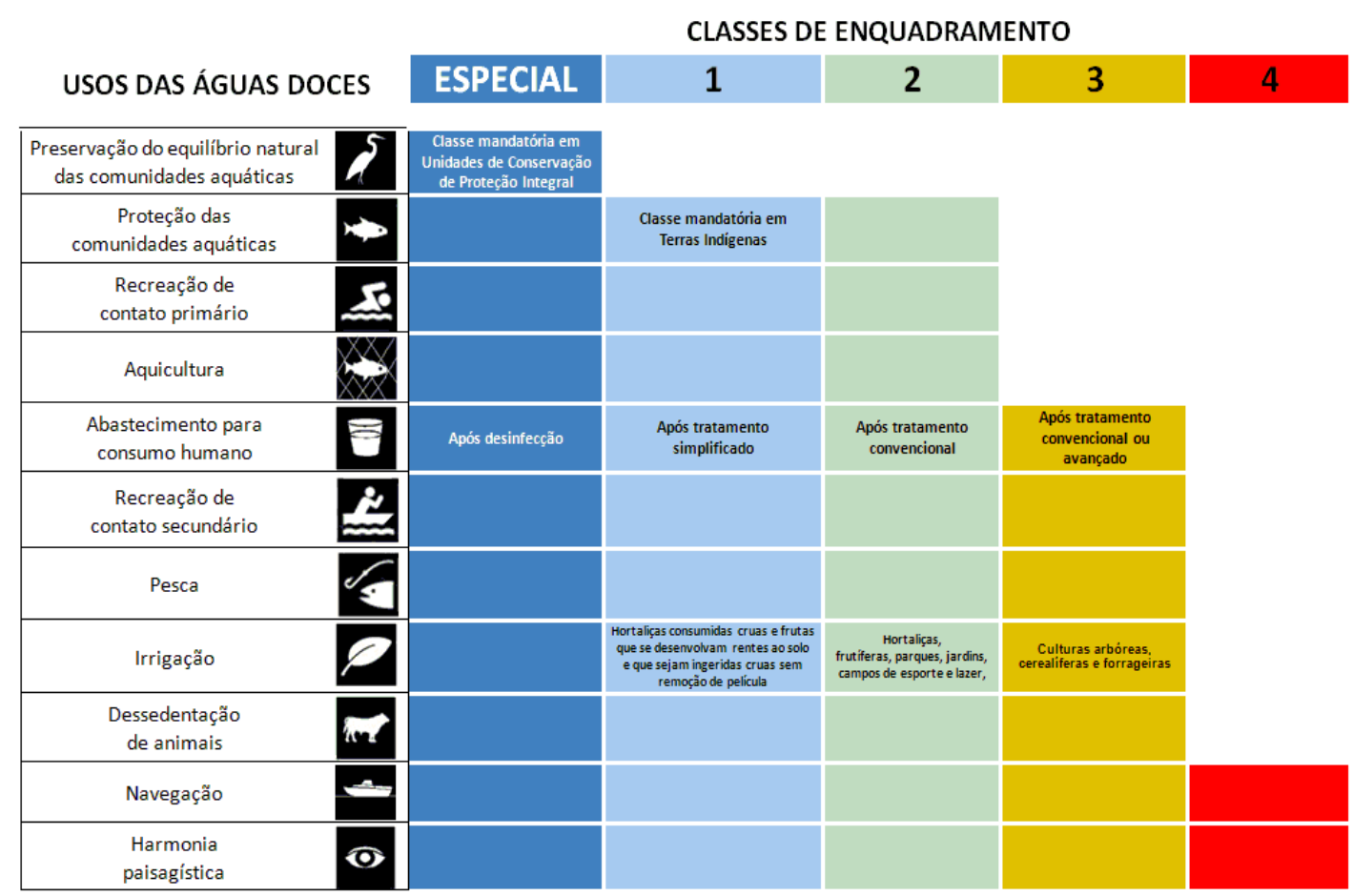

Fonte: ANA (2014)

\subsection{Potabilidade da água}

A norma vigente de potabilidade da água para consumo humano é a Portaria do Ministério da Saúde no 2.914 (2011), que revogou a Portaria MS n 518 (2004) e dispõe sobre o padrão de potabilidade e os procedimentos de controle e de vigilância da qualidade da água para consumo humano.

Nesta norma ratificam-se definições importantes, como a insculpida no art. $2^{\circ} \S 5^{\circ}$ :

- Água para consumo humano: água potável destinada à ingestão, preparação e produção de alimentos e à higiene pessoal, independentemente da sua origem;

- Água potável: água que atenda ao padrão de potabilidade estabelecido na Portaria e que não ofereça riscos à saúde.

Como a água utilizada em torneiras e chuveiros destina-se à higiene pessoal, deve ser observado o padrão de potabilidade estabelecido na Portaria MS $n^{\circ}$ 2.914/2011. No que concerne à água utilizada em vasos sanitários, a exigência de qualidade da água é menos restritiva, possibilitando o uso de fontes alternativas, como águas cinzas, desde que as tubulações e reservatórios destinados para esse fim não se interliguem com as instalações de água potável. 


\subsection{Programas federais}

O Poder Público, em todas as esferas de governo, eventualmente lança programas vinculados ao tema de conservação de água, cujos reflexos chegam às edificações públicas ou aos sistemas urbanos dos quais elas fazem parte. Dentre eles, destacam-se o Plano Nacional de Combate ao Desperdício de Água - PNCDA (1999) e a Agenda Ambiental na Administração Pública - A3P (2000).

O PNCDA foi criado em 1999 e revisado em 2003, no âmbito do Ministério das Cidades. Seu texto planeja ações de conservação e propõe tecnologias aos sistemas públicos de abastecimento, bem como aos sistemas prediais de água e esgoto. Destaca-se, entre seus objetivos específicos, a definição e implantação de ações e instrumentos tecnológicos, normativos, econômicos e institucionais, concorrentes para uma efetiva economia dos volumes de água demandados para consumo nas áreas urbanas.

Dentre as publicações do PNCDA, chamam a atenção os Documentos Técnicos de Apoio (DTAs), elaborados entre 1999 e 2003, que tratam de estratégias de combate ao desperdício de água e de códigos de prática de projeto e execução de sistemas economizadores de água, entre outros.

A Agenda Ambiental na Administração Pública (A3P) se tornou o principal programa da administração pública de gestão socioambiental. O programa tem sido implantado por diversos órgãos e instituições públicas das três esferas de governo e pode ser usado como modelo de gestão socioambiental por outros segmentos da sociedade.

Criado em 2000, foi reconhecida no ano seguinte pela UNESCO devido à relevância do trabalho desempenhado e dos resultados positivos obtidos ao longo do seu desenvolvimento, ganhando o prêmio "O melhor dos exemplos" na categoria Meio Ambiente.

\subsection{Normatização}

As normas não são regulamentos técnicos e não há obrigatoriedade na sua adoção. $\mathrm{O}$ projetista ou construtor as adotam para diminuir a incidência de erros na execução dos projetos, como uma ferramenta de auxílio ao cumprimento da legislação. Na ABNT existem comitês técnicos, que são responsáveis pelo desenvolvimento das normas, incluindo reuniões com especialistas e chamadas públicas para discussão dos temas tratados.

Um dos mais atuantes e abrangentes é o Comitê Brasileiro de Construção Civil (ABNT/CB02), responsável inclusive por definições na área de sustentabilidade e conservação de água 
em edificações. A primeira norma que se destaca neste cenário é a NBR 13969 (1997), que trata de projetos, construção e operação de tanques sépticos como unidades de tratamento complementar e disposição final dos efluentes líquidos. Essa norma tem por objetivo oferecer alternativas de procedimentos técnicos para unidades de tratamento complementar e disposição final dos efluentes líquidos de tanques sépticos, dentro do sistema de tratamento local de esgotos.

As alternativas devem ser selecionadas de acordo com as necessidades e condições locais de onde é implantado o sistema de tratamento, não havendo restrições quanto à capacidade de tratamento das unidades.

No caso do esgoto essencialmente doméstico ou com características similares, o esgoto tratado deve ser reutilizado para fins que exigem qualidade de água não potável, mas sanitariamente segura, tais como irrigação dos jardins, lavagens dos pisos e dos veículos automotivos, descarga dos vasos sanitários, manutenção paisagística dos lagos e canais com água e irrigação dos campos agrícolas e pastagens, dentre outros (ABNT NBR 13969, 1997, p. 2).

A norma admitiu a simples recirculação de água de enxágue da máquina de lavar para os vasos sanitários. Ela também inovou ao adotar o sistema de reúso, de modo a permitir sua utilização segura e racional, além de minimizar custos de implantação e de operação. Para isso, deve ser considerado o seu uso e o volume de esgoto a ser reutilizado para definir o grau de tratamento necessário. No Quadro 3 há uma síntese das classes e da respectiva utilização prevista na norma.

Quadro 3 - Classes e utilizações das águas de reúso

\begin{tabular}{|c|c|}
\hline $\begin{array}{c}\text { Grau de } \\
\text { tratamento }\end{array}$ & Utilização prevista para a água de reúso \\
\hline Classe 1 & $\begin{array}{r}\text { Lavagem de carros e outros usos que requerem contato direto do usuário com a água, com } \\
\text { possível aspiração de aerossóis pelo operador. }\end{array}$ \\
\hline Classe 2 & $\begin{array}{r}\text { Lavagens de pisos, calçadas e irrigação dos jardins, manutenção de lagos e canais para fins } \\
\text { paisagísticos. }\end{array}$ \\
\hline Classe 3 & Reúso na descarga dos vasos sanitários. \\
\hline Classe 4 & $\begin{array}{r}\text { Reúso nos pomares, cereais, forragens, pastagens para gado e outros cultivos através de } \\
\text { escoamento superficial ou por sistema de irrigação pontual. }\end{array}$ \\
\hline
\end{tabular}

Fonte: ABNT NBR 13969 (1997)

A segunda norma que se pode destacar é a NBR 15527 (2007), que fornece requisitos de aproveitamento de água de chuva em coberturas em áreas urbanas, para fins não potáveis. O objetivo é fornecer diretrizes básicas para o aproveitamento de água de chuva para fins não potáveis em áreas urbanas para os seguintes usos: descargas em bacias sanitárias, irrigação de 
gramados por aspersão ou gotejamento e plantas ornamentais, lavagem de veículos, limpeza de calçadas e ruas, limpeza de pátios, espelhos d'água e usos industriais.

Segundo a norma, no sistema de aproveitamento de águas de chuva, devem ser instalados, nas calhas das coberturas, dispositivos para a remoção de detritos, como grades ou telas, por exemplo. Também há menção expressa aos cuidados com animais, para que não entrem nos reservatórios.

No que tange ao descarte das primeiras águas de chuva, a NBR 15527:2007 recomenda que os dispositivos sejam automáticos e dimensionados pelo projetista. Na falta de dados, aconselhase o descarte de $2 \mathrm{~mm}$ da precipitação inicial. Recomenda-se que haja dois reservatórios, sendo um para água potável e outro para água não potável, que será usado para o aproveitamento da água de chuva.

Os pontos de consumo, como, por exemplo, uma torneira de jardim, devem ser identificados com placa de advertência com a inscrição "água não potável” e advertência visual destinada às pessoas que não saibam ler e às crianças.

Outras normas são importantes quando se consideram as instalações hidráulicas de um edifício e devem sempre ser consultadas em caso de dúvidas dos profissionais envolvidos desde o projeto, passando pela execução e manutenção dos edifícios. Estas normas estão listadas no Quadro 4.

Quadro 4 - Normas técnicas de uso de água correlatas à NBR 13969 e NBR 15527

\begin{tabular}{|c|c|c|}
\hline Norma & Assunto & Descrição \\
\hline $\begin{array}{c}\text { NBR } 10844 \\
(1989)\end{array}$ & $\begin{array}{l}\text { Instalações } \\
\text { prediais de } \\
\text { drenagem }\end{array}$ & $\begin{array}{c}\text { Fixa as exigências necessárias aos projetos das instalações de drenagem de } \\
\text { águas pluviais, visando a garantir níveis aceitáveis de funcionalidade, } \\
\text { segurança, higiene, conforto, durabilidade e economia. }\end{array}$ \\
\hline $\begin{array}{c}\text { NBR } 7198 \\
(1993)\end{array}$ & $\begin{array}{l}\text { Instalações } \\
\text { prediais de } \\
\text { água quente }\end{array}$ & $\begin{array}{c}\text { Fixa as exigências técnicas mínimas quanto à higiene, à segurança, à economia } \\
\text { e ao conforto dos usuários, pelas quais devem ser projetadas e executadas as } \\
\text { instalações prediais de água quente. }\end{array}$ \\
\hline $\begin{array}{c}\text { NBR } 7229 \\
(1993)\end{array}$ & $\begin{array}{l}\text { Sistemas de } \\
\text { tanques } \\
\text { sépticos }\end{array}$ & $\begin{array}{l}\text { Fixa as condições exigíveis para projeto, construção e operação de sistemas de } \\
\text { tanques sépticos, incluindo tratamento e disposição de afluentes e lodo } \\
\text { sedimentado. Seu objetivo é preservar a saúde pública e ambiental, a higiene, o } \\
\text { conforto e a segurança dos habitantes de áreas servidas por estes sistemas. }\end{array}$ \\
\hline $\begin{array}{c}\text { NBR } 5626 \\
(1998)\end{array}$ & $\begin{array}{l}\text { Instalações } \\
\text { prediais de } \\
\text { água fria }\end{array}$ & $\begin{array}{l}\text { Estabelece exigências e recomendações relativas ao projeto, execução e } \\
\text { manutenção da instalação predial de água fria. Emanam fundamentalmente do } \\
\text { respeito aos princípios de bom desempenho da instalação e da garantia de } \\
\text { potabilidade da água no caso de instalação de água potável. }\end{array}$ \\
\hline $\begin{array}{c}\text { NBR } 8160 \\
(1999)\end{array}$ & $\begin{array}{c}\text { Sistemas } \\
\text { prediais de } \\
\text { esgoto sanitário }\end{array}$ & $\begin{array}{c}\text { Estabelece as exigências e recomendações relativas ao projeto, execução, } \\
\text { ensaio e manutenção dos sistemas prediais, de esgoto sanitário, para atenderem } \\
\text { às exigências mínimas quanto à higiene, segurança e conforto dos usuários, } \\
\text { tendo em vista a qualidade destes sistemas. }\end{array}$ \\
\hline
\end{tabular}

Fonte: ABNT 


\subsection{Legislação de estados e municípios}

Segundo Justen Filho (2005), os serviços de saneamento básico têm direta pertinência com os direitos fundamentais (arts. $1^{\circ}$ e $3^{\circ}$ da Constituição Federal), não restringindo a titularidade desses serviços exclusivamente a uma categoria de entes federativos. Segundo o mesmo autor, a Carta Magna reservou competências explícitas para União e estados atuarem neste setor, como no caso do art. 23, incisos VI (proteção do meio ambiente e combate à poluição) e XI (fiscalização da exploração de serviços hídricos) e no art. 21, XIX, que trata do sistema nacional de gerenciamento de recursos hídricos.

Quando são levantadas as iniciativas implantadas pelos estados e municípios brasileiros, não obstante as políticas públicas federais atinentes ao tema, conclui-se que o Governo Federal ainda tem muito a avançar. $\mathrm{O}$ autor supracitado afirma que a promoção de saneamento básico à população é dever de todos: União, estados e Distrito Federal e municípios. O art. 26, I determina serem de domínio dos estados as águas superficiais ou subterrâneas. Há interesse, portanto, dos estados na captação das águas para a prestação dos serviços públicos.

Tanto nos estados quanto nos municípios, há vários exemplos de adoção de políticas públicas, por meio de implantação de ordenamento legal específico, que privilegiam a conservação da água em edificações.

No Estado de São Paulo, por exemplo, a Lei Estadual no 12.526 (2007) é uma norma direcionada para a contenção de enchentes e destinação de águas pluviais, sendo obrigatória a implantação de sistema para a captação e retenção de águas pluviais, coletadas por telhados, coberturas, terraços e pavimentos descobertos, em lotes, edificados ou não, que tenham área impermeabilizada superior a $500 \mathrm{~m}^{2}$. Seu teor é idêntico ao da Lei Municipal $\mathrm{n}^{\circ} 13.276$ (2002), do Município de São Paulo.

O Decreto Estadual 48.138 (2003), também do Estado de São Paulo, define medidas de redução de consumo e racionalização do uso de água. Entre as regras definidas, estão, por exemplo, as que obrigam a limpeza das ruas e praças só por varredura e recolhimento de detritos, sendo vedada lavagem com água potável, exceto em casos que se confirme existência de material contagioso ou que traga danos à saúde. Nesse caso, é permitida lavagem somente com água de reúso ou outras fontes (águas de chuva e poços com água não contaminada).

No Quadro 5 são detalhados alguns exemplos representativos dessas iniciativas em diversos municípios brasileiros, mostrando a abrangência das medidas, sem entrar no mérito da 
eficiência destas legislações. Ainda há muito que se modernizar na legislação brasileira sobre o assunto, especialmente no que diz respeito à educação e conscientização da população brasileira, à responsabilidade dos agentes públicos na elaboração das leis e à fiscalização dos entes federativos do cumprimento das medidas.

A compulsoriedade de certas iniciativas ou a inclusão de incentivos fiscais também são exemplos eficientes de políticas públicas. Blumenschein (2004) afirma que é necessária a identificação de instrumentos de política ambiental que vêm sendo usados para a introdução de mudanças compatíveis com a preservação do meio ambiente, em que encontramos, por exemplo, os de comando e controle (coercitivos) e os econômicos (incitativos), cujos critérios de implementação são, entre outros, o baixo custo e a aceitação política. Tais posturas são recomendadas justamente pelo poder de polícia que o Governo exerce sobre os órgãos públicos, apesar da independência no campo administrativo.

Quadro 5 - Exemplos de legislação municipal de conservação de água

\begin{tabular}{|c|c|c|}
\hline Localização & Lei / Norma & Assunto \\
\hline $\begin{array}{l}\text { Passo } \\
\text { Fundo/RS }\end{array}$ & $\begin{array}{l}\text { Lei } \\
\text { Complementar } \\
\mathrm{n}^{\mathbf{o}} 110 \\
(2003)\end{array}$ & $\begin{array}{l}\text { Medição individual nas edificações residenciais multifamiliares e } \\
\text { comerciais. }\end{array}$ \\
\hline Blumenau/SC & $\begin{array}{l}\text { Lei Municipal } \\
\mathrm{n}^{\mathrm{o}} 5.935 \\
\quad(2002)\end{array}$ & $\begin{array}{l}\text { Obrigatória a instalação de dispositivos hidráulicos para novos prédios } \\
\text { públicos e privados não residenciais, tais como: torneiras para pias, } \\
\text { registros para chuveiros, válvulas para mictórios (acionados manualmente } \\
\text { e com ciclo de fechamento automático ou acionados por sensor de } \\
\text { proximidade) e bacias sanitárias com volume de descarga reduzido (VDR). }\end{array}$ \\
\hline Curitiba/PR & $\begin{array}{l}\text { Lei Municipal } \\
\mathrm{n}^{\mathbf{o}} 10.785 \\
\quad(2003)\end{array}$ & $\begin{array}{l}\text { Cria o programa de conservação e uso racional da água nas edificações - } \\
\text { PURAE: Obrigatória a utilização de aparelhos e dispositivos } \\
\text { economizadores de água: bacias sanitárias de volume reduzido de } \\
\text { descarga, chuveiros e lavatórios de volumes fixos de descarga e torneiras } \\
\text { dotadas de arejadores; Exigência de hidrômetros para medição } \\
\text { individualizada de condomínios; Obrigatória a captação da água das } \\
\text { chuvas na cobertura das edificações e encaminhada a cisterna ou tanque, } \\
\text { para ser utilizada em rega de jardins e hortas, lavagem de roupa, lavagem } \\
\text { de veículos e lavagem de vidros, calçadas e pisos. }\end{array}$ \\
\hline \multirow[b]{2}{*}{ Maringá/PR } & $\begin{array}{l}\text { Lei Municipal } \\
\mathrm{n}^{\circ} 6.345 \\
(2003)\end{array}$ & $\begin{array}{l}\text { Incentivos para a instalação de reservatórios para a contenção de águas } \\
\text { servidas e para o recolhimento de águas das chuvas. }\end{array}$ \\
\hline & $\begin{array}{l}\text { Lei Municipal } \\
\mathrm{n}^{\mathrm{o}} 6.339 \\
\quad(2003)\end{array}$ & $\begin{array}{l}\text { Obrigatória a instalação de dispositivos hidráulicos para o controle e a } \\
\text { redução do consumo de água em todos os empreendimentos imobiliários, } \\
\text { públicos e privados, não residenciais. As edificações já construídas } \\
\text { tiveram cinco anos para adequarem suas instalações. }\end{array}$ \\
\hline São Paulo/SP & $\begin{array}{l}\text { Lei Municipal } \\
\mathrm{n}^{\mathbf{o}} 13.309 \\
\quad(2002)\end{array}$ & $\begin{array}{l}\text { Utilização de água de reúso, não potável, proveniente das estações de } \\
\text { tratamento de esgoto, para a lavagem de ruas, praças públicas, passeios } \\
\text { públicos e próprios municipais, bem como para a irrigação de jardins, } \\
\text { praças, campos esportivos e outros equipamentos, considerando o } \\
\text { custo/benefício dessas operações. O decreto define que esses usos serão } \\
\text { realizados com água de reúso, não potável, proveniente de ETEs, } \\
\text { analisadas sua viabilidade técnica e a vantagem econômica de sua } \\
\text { utilização. }\end{array}$ \\
\hline
\end{tabular}




\begin{tabular}{|c|c|c|}
\hline Localização & Lei / Norma & Assunto \\
\hline & $\begin{array}{l}\text { Lei Municipal } \\
\mathrm{n}^{\mathbf{o}} 14.018 \\
\quad(2005)\end{array}$ & $\begin{array}{l}\text { Programa Municipal de Conservação e Uso Racional da Água em } \\
\text { Edificações: Estabelece prazo de } 10 \text { anos para a adequação dos imóveis às } \\
\text { exigências da lei, no que tange à captação, armazenamento e } \\
\text { aproveitamento de águas pluviais e águas servidas. }\end{array}$ \\
\hline Viçosa/MG & $\begin{array}{l}\text { Lei Municipal } \\
\mathrm{n}^{\circ} 1.440 \\
\quad(2001)\end{array}$ & $\begin{array}{l}\text { Controle de excesso de consumo de água e fiscalização de desperdícios de } \\
\text { água distribuída, tais como lavar calçadas com uso contínuo de água, } \\
\text { molhar ruas e lavar veículo em domicílios residenciais. }\end{array}$ \\
\hline Recife/PE & $\begin{array}{l}\text { Lei Municipal } \\
\mathrm{n}^{\mathbf{o}} 16.759 \\
\quad(2002)\end{array}$ & $\begin{array}{l}\text { Obrigatoriedade da instalação de hidrômetros individuais nos edifícios, } \\
\text { independentemente da categoria de usuários a que pertençam (residenciais, } \\
\text { comerciais, públicos, mistos) e da área das unidades. }\end{array}$ \\
\hline & $\begin{array}{l}\text { Lei Municipal } \\
\mathrm{n}^{\mathbf{o}} 2.630 \\
\quad(2009)\end{array}$ & $\begin{array}{l}\text { Armazenamento de águas pluviais para reaproveitamento (fins não } \\
\text { potáveis) e retardo da descarga na rede pública, para novas edificações, } \\
\text { públicas ou privadas, que tenham área impermeabilizada superior a } 500 \\
\text { metros quadrados, bem como edificações coletivas, residenciais, } \\
\text { comerciais ou mistas, que tenham mais de } 50 \text { (cinquenta) unidades. }\end{array}$ \\
\hline Niterói/RJ & $\begin{array}{l}\text { Lei Municipal } \\
\mathrm{n}^{\mathbf{0}} 2.856 \\
\quad(2011)\end{array}$ & $\begin{array}{l}\text { Mecanismos de estímulo à instalação de sistema de coleta e reutilização de } \\
\text { águas servidas em edificações públicas e privadas. } \\
\text { Aplica-se às obras novas que tenham consumo de volume igual ou } \\
\text { superior a } 20 \text { (vinte) metros cúbicos de água por dia. } \\
\text { As águas servidas serão direcionadas através de encanamentos } \\
\text { (tubulações, conexões e bombas) próprios, com cores específicas, e } \\
\text { armazenadas em reservatórios distintos e independentes dos reservatórios } \\
\text { de águas potáveis, que servirão para a lavagem de pátios, escadarias, } \\
\text { jardinagem e também ao abastecimento das descargas dos vasos sanitários, } \\
\text { as quais serão descarregadas na rede pública de esgoto. }\end{array}$ \\
\hline Guarulhos/SP & $\begin{array}{l}\text { Lei Municipal } \\
\mathrm{n}^{\circ} 6.793 \\
(2010)\end{array}$ & $\begin{array}{l}\text { IPTU Verde - Descontos nos valores anuais do IPTU } \\
\text { Desconto de até 5\%: Imóveis com calçadas adaptadas para trânsito livre e } \\
\text { seguro de pedestres e cadeirantes, mantendo de } 1 \text { a } 1,5 \text { metro para } \\
\text { circulação. Desconto de até } 2 \% \text { : Imóveis com uma ou mais árvores ou } \\
\text { com jardins/gramados que permitam a absorção das águas das chuvas. } \\
\text { Desconto de } 3 \% \text { : Uso de sistema de captação de água de chuva, ou de } \\
\text { reúso de água, ou de aquecimento solar de água ou de aquecimento } \\
\text { elétrico solar; construções com materiais sustentáveis; utilização de } \\
\text { energia passiva (quando o projeto arquitetônico propicia o melhor } \\
\text { aproveitamento da luz solar, dispensando o uso de ar-condicionado e } \\
\text { iluminação artificial); uso de telhado verde (vegetação em cima dos } \\
\text { telhados da casa). Desconto de 5\%: Utilização de energia eólica; } \\
\text { separação de resíduos sólidos (exclusivo para condomínios que } \\
\text { comprovem a destinação de sua coleta para reciclagem). }\end{array}$ \\
\hline $\begin{array}{l}\text { Florianópolis/ } \\
\text { SC }\end{array}$ & $\begin{array}{l}\text { Lei Municipal } \\
\mathrm{n}^{\circ} 8.080 \\
(2009)\end{array}$ & $\begin{array}{l}\text { Programa Municipal de Conservação, Uso Racional e Reúso da Água em } \\
\text { Edificações. São utilizados aparelhos e dispositivos economizadores de } \\
\text { água em habitações até } 70 \mathrm{~m}^{2} \text {. A água proveniente das chuvas será } \\
\text { coletada na cobertura das edificações e armazenada em cisterna ou tanque } \\
\text { para utilização em atividades que não requeiram o uso de água tratada } \\
\text { proveniente da rede pública de abastecimento. } \\
\text { Referem-se a novas edificações, mas podem ser concedidos incentivos } \\
\text { fiscais a edificações existentes que se adaptarem às regras. É exigido para } \\
\text { emissão de alvará de construção de novas edificações. }\end{array}$ \\
\hline
\end{tabular}

Fontes: Blumenau (2002); Curitiba (2003); Florianópolis (2009); Guarulhos (2010); Maringá (2003a; 2003b); Niterói (2009; 2011); Passo Fundo (2003); Recife (2002); São Paulo (2002; 2005); Viçosa (2001).

\subsection{Legislação no Distrito Federal}

No Distrito Federal, a política pública relativa à conservação de água em meio urbano ou em edifícios pode ser resumida cronologicamente no Quadro 6. A CAESB, concessionária responsável pelo saneamento básico no Distrito Federal, aprovou uma norma específica para 
reúso de água. A norma ND.SCO-013 (2012) tem como objetivo estabelecer procedimentos de avaliação de projetos e vistorias em sistemas que preveem o reúso de água e/ou o aproveitamento de água pluvial, de forma a evitar a contaminação da água tratada distribuída pela CAESB, bem como fixar critérios para o lançamento dos efluentes desses sistemas na rede pública de esgoto.

Na norma supra, a água proveniente dos sistemas de conservação de água poderá ser utilizada somente para irrigação não pressurizada de jardins e áreas verdes, lavação de veículos, de pisos e calçadas, tanques e canais para fins paisagísticos (exceto chafarizes), torres de resfriamento de sistemas de ar condicionado central e descarga em vasos sanitários, desde que submetida a um tratamento simplificado.

Quadro 6 - Leis relativas à conservação de água no Distrito Federal

\begin{tabular}{|c|c|}
\hline Lei & Características \\
\hline $\begin{array}{c}\text { Lei DF n } \\
41 / 1989\end{array}$ & $\begin{array}{l}\text { Essa lei foi precursora. Tratava da Política Ambiental do DF e retratava diretrizes e orientações } \\
\text { gerais de preservação ambiental. Previa, em seus artigos } 25 \text { e } 28 \text {, a obrigatoriedade dos } \\
\text { proprietários de imóveis de execução de instalações adequadas de água e esgoto. }\end{array}$ \\
\hline $\begin{array}{c}\text { Lei DF n } \\
2.616 / 2000\end{array}$ & $\begin{array}{l}\text { Tornou obrigatória a utilização de equipamentos economizadores de água nas instalações } \\
\text { hidráulicas e sanitárias dos edifícios públicos e privados destinados a uso não residencial no } \\
\text { âmbito do Distrito Federal. Estão incluídos os edifícios públicos federais, edifícios administrados } \\
\text { ou de propriedade do Governo do Distrito Federal, centros comerciais, escolas, hospitais, } \\
\text { indústrias, edifícios de escritórios, lojas, bares e restaurantes. }\end{array}$ \\
\hline $\begin{array}{c}\text { Lei DF no } \\
2.725 / 2001\end{array}$ & $\begin{array}{l}\text { Aprovada quatro anos depois da publicação da PNRH pelo Governo Federal, esta lei se adapta às } \\
\text { orientações federais e institui a Política de Recursos Hídricos e o Sistema de Gerenciamento de } \\
\text { Recursos Hídricos no DF. O texto segue em muitos aspectos a legislação federal, como a } \\
\text { racionalização do uso da água, as classes de uso e a outorga. }\end{array}$ \\
\hline $\begin{array}{c}\text { Lei DF n } \\
4.181 / 2008\end{array}$ & $\begin{array}{l}\text { Criou o Programa de Captação de Água da Chuva, cujos objetivos são a captação, o } \\
\text { armazenamento e a utilização das águas pluviais pelas edificações urbanas. Na referida lei, a } \\
\text { concessão de habite-se para as construções iniciadas após sua vigência ficou condicionada à } \\
\text { comprovação do cumprimento das regras. Nesta lei, é estimulada a instalação, nas casas e prédios, } \\
\text { públicos e particulares, com mais de duzentos metros quadrados de área construída, de caixas ou } \\
\text { reservatórios de água, coletores e armazenadores destinados unicamente ao armazenamento de } \\
\text { água pluvial. }\end{array}$ \\
\hline $\begin{array}{c}\text { Lei DF n } \\
4.671 / 2011\end{array}$ & $\begin{array}{l}\text { Complementa a lei anterior, dispondo desta vez sobre a obrigatoriedade da instalação de } \\
\text { reservatórios de captação de água para as unidades habitacionais e comerciais do Distrito Federal. } \\
\text { Os novos empreendimentos residenciais coletivos ou individuais, comerciais e industriais com } \\
\text { área computável construída igual ou superior a } 300 \mathrm{~m}^{2} \text { ficaram obrigados a dispor de coletores, } \\
\text { caixa de armazenamentos e distribuidores para água da chuva. } \\
\text { Ficou definida na lei supracitada que a utilização da água da chuva será para usos secundários, } \\
\text { como lavagem de prédios, lavagem de automóveis, irrigação de jardins, limpeza e descarga de } \\
\text { vaso sanitário, entre outros, e que os novos projetos de construção civil teriam o prazo de dois } \\
\text { anos, contados da publicação da lei, para se adequarem ao seu cumprimento. }\end{array}$ \\
\hline
\end{tabular}

Fonte: DISTRITO FEDERAL [(1989); (2000); (2001); (2008); (2011)]

O usuário dos serviços da empresa que adotar esses sistemas em suas edificações passa à condição de produtor desse tipo de insumo e torna-se responsável pela sua gestão qualitativa e quantitativa, juntamente com o responsável técnico pelo projeto ou pela operação dos sistemas. O único assunto formalmente postergado foi o da medição do volume de efluente 
proveniente desses sistemas e lançado na rede pública de esgoto, que, para fins de faturamento, deverá atender ao disposto em norma específica, ainda não publicada ${ }^{3}$.

\subsection{Certificações e selos de eficiência hídrica}

Bibiano (2013) conceitua um certificado de construção sustentável como aquele que caracteriza, sob o ponto de vista ambiental, social, econômico e cultural, o empreendimento desde a fase do projeto até a sua implantação, configurando a sua eficiência. No mercado existem diversos sistemas de certificação sustentável de edifícios e selos que identificam equipamentos e sistemas economizadores de água, conforme exemplos elencados nos Quadros 7 e 8.

Quadro 7 - Exemplos de selos e certificações de edifícios com enfoque em eficiência energética e respectivo peso das ações de eficiência hídrica na nota final

\begin{tabular}{|c|c|c|c|}
\hline $\begin{array}{l}\text { Certificação } \\
\text { Selo } \\
\text { (País) }\end{array}$ & $\begin{array}{l}\text { Área de } \\
\text { atuação }\end{array}$ & Características de eficiência hídrica & $\begin{array}{l}\text { Peso } \\
(\%)\end{array}$ \\
\hline $\begin{array}{l}\text { BREEAM } \\
\text { (Inglaterra) }\end{array}$ & $\begin{array}{l}\text { Desempenho } \\
\text { ambiental de } \\
\text { edifícios }\end{array}$ & $\begin{array}{l}\text { Lançado em 1990. Atualizado a cada } 2 \text { anos. Obrigatório em } \\
\text { todos os edifícios novos e reformados do governo central. } \\
\text { Consumo de água interno (litros/pessoa/dia) => categoria } \\
\text { obrigatória, com } 5 \text { pontos possíveis, variando de } 120 \text { litros ( } 1 \\
\text { ponto) a } 80 \text { litros diários ( } 5 \text { pontos) per capita. Os sistemas AAP } \\
\text { e TAC para uso não potável são contemplados nesta categoria. } \\
\text { Quanto ao consumo externo (irrigação), o sistema reserva apenas } \\
\text { um ponto no cálculo total e não é um requisito da certificação. }\end{array}$ & 6 \\
\hline $\begin{array}{l}\text { LEED } \\
\text { (EUA) }\end{array}$ & $\begin{array}{l}\text { Construções } \\
\text { sustentáveis }\end{array}$ & $\begin{array}{l}\text { Desenvolvido em 1998. É exigido para todos os edifícios públicos } \\
\text { americanos. O uso eficiente da água divide-se em três categorias: } \\
\text { a) sistemas AAP, TAC e TAR; b) irrigação; c) EEAs. }\end{array}$ & 10,9 \\
\hline $\begin{array}{l}\text { AQUA } \\
\text { (Brasil) }\end{array}$ & $\begin{array}{l}\text { Certificação } \\
\text { de qualidade } \\
\text { ambiental de } \\
\text { edifícios }\end{array}$ & $\begin{array}{l}\text { Lançado em 2008. Duas das quatorze categorias de qualidade } \\
\text { ambiental dos edifícios têm vínculos com a eficiência hídrica: } \\
\text { gestão da água e qualidade sanitária da água. }\end{array}$ & 14,3 \\
\hline $\begin{array}{l}\text { LIDERA } \\
\text { (Portugal) }\end{array}$ & $\begin{array}{l}\text { Construções } \\
\text { Sustentáveis }\end{array}$ & $\begin{array}{l}\text { Criado em 2000. Dentre as } 22 \text { áreas e } 43 \text { critérios previstos, a } \\
\text { água é a segunda área de maior importância. Divide-se em duas } \\
\text { categorias: a) consumo de água potável (redução do consumo, } \\
\text { TAC e TAR); b) gestão das águas locais (redução de vazamentos, } \\
\text { atenuação de cheias e AAP). }\end{array}$ & 8 \\
\hline $\begin{array}{l}\text { PROCEL } \\
\text { (Brasil) }\end{array}$ & $\begin{array}{l}\text { Certificação } \\
\text { de eficiência } \\
\text { energética em } \\
\text { edifícios }\end{array}$ & \multicolumn{2}{|l|}{$\begin{array}{l}\text { Instituído em 2003. Selo categoria "A" obrigatório para todas as } \\
\text { edificações públicas federais desde agosto de } 2014 \text {. Entre as bonificações } \\
\text { existentes, estão sistemas e equipamentos que racionalizam o uso da água, } \\
\text { como torneiras com arejadores, sanitários com sensores ou com válvula de } \\
\text { descarga com duplo acionamento, sistemas de aproveitamento de água } \\
\text { pluvial, redução de perdas por condensação da água de torres de } \\
\text { arrefecimento, reúso de água, entre outras soluções. }\end{array}$} \\
\hline
\end{tabular}

Fontes: Sítios eletrônicos diversos: www.breeam.org; www.usgbc.org; www.vanzolini.org.br, www.lidera.info e www.procelinfo.com.br

\footnotetext{
${ }^{3}$ Outra iniciativa que aguarda aprovação é o Projeto de Lei no 570/2011, ainda em tramitação na Câmara Legislativa do Distrito Federal, que estabelece diretrizes para as políticas públicas de reúso da água no Distrito Federal.
} 
Não obstante esses sistemas avaliarem o edifício sob vários aspectos, só será abordada a vertente de eficiência hídrica, que vem sendo implementada em vários países, de forma voluntária. Há países em que a certificação não se dá por meio de uma escala de eficiência hídrica, mas sim como um rótulo de eficiência atribuído quando os consumos se situam abaixo de um determinado valor.

No Brasil, os sistemas de certificação de maior representatividade atualmente são: o United States Green Buiding Council (USGBC), que possui o selo Leadership in Energy and Environmental Design (LEED) e 279 certificados emitidos no Brasil; o selo AQUA (Alta Qualidade Ambiental), vinculado à Fundação Vanzolini, que possui 375 certificações emitidas no Brasil; e o Procel Edifica, hoje chamado Procel Edificações, que é vinculado à Eletrobrás e já emitiu mais de duas mil etiquetas desde 2009.

Quadro 8 - Exemplos de selos e certificações de edifícios com enfoque em eficiência hídrica

\begin{tabular}{|c|c|c|}
\hline $\begin{array}{l}\text { Certificação } \\
\text { Selo } \\
\text { (País) }\end{array}$ & $\begin{array}{l}\text { Área de } \\
\text { atuação }\end{array}$ & Características de eficiência hídrica \\
\hline $\begin{array}{c}\text { ANQIP } \\
\text { (Portugal) }\end{array}$ & $\begin{array}{l}\text { Selo de } \\
\text { eficiência } \\
\text { hídrica de } \\
\text { equipamentos }\end{array}$ & $\begin{array}{l}\text { Criado em 2008. Sistema voluntário de rotulagem de dispositivos hídricos } \\
\text { (vaso sanitários, chuveiros, torneiras), que poderá vir a ter caráter } \\
\text { obrigatório após um período de transição. A eficiência considerada ideal } \\
\text { corresponde à letra A e a de menor eficiência, à letra E. Há casos de } \\
\text { categorias "A+" e "A++" com aplicações limitadas e condicionadas. }\end{array}$ \\
\hline $\begin{array}{l}\text { ECOLABEL } \\
\text { (Comunidade } \\
\text { Européia) } \\
\end{array}$ & $\begin{array}{c}\text { Impacto } \\
\text { ambiental de } \\
\text { equipamentos }\end{array}$ & $\begin{array}{l}\text { Criado em 1992. Na área hídrica, destaca-se pelas certificações dadas a } \\
\text { eletrodomésticos que consomem água, como, por exemplo, máquinas de } \\
\text { lavar roupa e lavar louças. }\end{array}$ \\
\hline $\begin{array}{l}\text { WATER } \\
\text { SENSE } \\
\text { (EUA) }\end{array}$ & $\begin{array}{c}\text { Selo de } \\
\text { eficiência } \\
\text { hídrica de } \\
\text { equipamentos }\end{array}$ & $\begin{array}{l}\text { Criado em 2006, é um programa da Agência de Proteção Ambiental dos } \\
\text { Estados Unidos (EPA). Os produtos que recebem este selo devem ser pelo } \\
\text { menos } 20 \% \text { mais econômicos que o normal. Participam fabricantes de } \\
\text { louças e metais, equipamentos de irrigação e de tubulações. }\end{array}$ \\
\hline $\begin{array}{l}\text { WELS } \\
\text { (Austrália e } \\
\text { Nova } \\
\text { Zelândia) }\end{array}$ & $\begin{array}{l}\text { Selo de } \\
\text { eficiência } \\
\text { hídrica de } \\
\text { equipamentos }\end{array}$ & $\begin{array}{l}\text { Criado em 2005. Informa ao consumidor a eficiência hídrica, consumo ou } \\
\text { vazão do dispositivo, permitindo assim uma escolha mais consciente do } \\
\text { consumidor. O sistema de classificação é por estrelas, com um máximo de } \\
\text { seis. Quanto maior o número de estrelas, mais eficiente é o equipamento. }\end{array}$ \\
\hline $\begin{array}{l}\text { WATER } \\
\text { WISE } \\
\text { (Inglaterra) }\end{array}$ & $\begin{array}{l}\text { Selo de } \\
\text { eficiência } \\
\text { hídrica de } \\
\text { equipamentos }\end{array}$ & $\begin{array}{l}\text { Fundado em 2005. Selo utilizado em equipamentos e sistemas } \\
\text { conservadores de água e baseado em referências europeias. É necessária } \\
\text { uma avaliação prévia da eficiência hídrica dos produtos e não há } \\
\text { categorias definidas. A presença do selo indica que o produto é } \\
\text { reconhecido como economizador de água. }\end{array}$ \\
\hline
\end{tabular}

Fontes: Sítios eletrônicos diversos: www.procelinfo.com.br; www.anqip.pt; www.ecolabel.eu; www.epa.gov/watersense; www.waterrating.gov.au e www.waterwise.org.uk

\subsection{Caracterização do edifício de uso público administrativo}

O processo de construção de edifícios que atendessem a fins específicos iniciou-se com a Revolução Industrial, durante a segunda metade do século XVIII e início do século XIX, quando os edifícios religiosos perderam espaço para indústrias e edifícios de escritórios. Surgiu a partir disso uma classificação, chamada por Gregotti (2001) de "tipo construtivo", ou 
seja, um conjunto de funções delimitadas que constituem um ou vários serviços unidos entre si por relações de continuidade espacial.

As edificações, segundo a Associação Brasileira de Normas Técnicas (ABNT), são conceituadas como "produtos constituídos por um conjunto de sistemas, elementos, ou componentes estabelecidos e integrados em conformidade com os princípios e técnicas da engenharia e da arquitetura" (NBR 5674:2012, item 3.1, p. 8).

A ABNT também define como usuário aquele que ocupa ou utiliza as dependências de uma edificação (NBR 14037:2011, item 3.9, p. 9). Para efeito desta pesquisa, define-se como edifício público aquele que é utilizado por agentes públicos ${ }^{4}$ ou políticos ${ }^{5}$, no exercício de seus mandatos, cargos, empregos ou funções públicas, em locais próprios ou alugados, para desempenho das atribuições dos órgãos a que se subordinam.

Dentro do serviço público existem serviços básicos que devem ser oferecidos à população, tais como o educacional, o hospitalar, o de segurança e o de transportes. Dentro de cada edificação que tenha predominantemente essas funções específicas, há profissionais que desempenham funções administrativas. Todavia, há edifícios em que o predomínio é de funções que se restringem ao serviço realizado em ambiente de escritórios, de pura gestão administrativa, documental ou processual, chamados também, dentro da área de direito, de órgãos administrativos.

Ao criar os entes políticos (União, Estados, Municípios e Distrito Federal), verificou-se a necessidade da divisão interna das atribuições de cada ente, em unidades administrativas com incumbência própria. Edifícios públicos administrativos são, portanto, aqueles que abrigam órgãos administrativos, que, segundo Faria (2011), são centros de competência, criados para a realização de serviço público ou desempenho de atividades-meio da Administração Pública.

Brasília, centro político-administrativo do Governo Federal, é a cidade ideal para uma pesquisa cujo foco são os edifícios públicos. A presença da sede dos principais órgãos públicos federais, de todos os poderes, a torna ideal para a escolha de um órgão para estudo de caso.

\footnotetext{
${ }^{4}$ A Lei de Improbidade Administrativa (Lei $n^{\text {o }}$ 8429/1992) conceitua agente público como todo aquele que exerce, ainda que transitoriamente ou sem remuneração, por eleição, nomeação, designação, contratação ou qualquer outra forma de investidura ou vínculo, mandato, cargo, emprego ou função na administração direta, indireta ou fundacional de qualquer dos Poderes da União, dos Estados, do Distrito Federal

${ }^{5}$ Segundo a Controladoria-Geral da União (CGU), o agente político é aquele detentor de cargo eletivo, eleito por mandatos transitórios, como os Chefes de Poder Executivo e membros do Poder Legislativo, além de cargos de Ministros de Estado e de Secretários nas unidades da Federação, os quais não se sujeitam ao processo administrativo disciplinar.
} 
Segundo o Ministério do Planejamento, Orçamento e Gestão - MPOG (2015), há 70 mil servidores públicos federais ativos do Executivo Federal no Distrito Federal, o que corresponde a $6,72 \%$ do total de servidores públicos de todo o País. Para se ter uma ideia do número de edificações, Silva (2007) identificou, por levantamento in loco, um total de 138 prédios públicos no DF, concentrados basicamente na Esplanada dos Ministérios e Setores de Autarquias, de Administração Federal e Bancário.

A população estudada contempla os servidores públicos que trabalham diariamente no órgão participante da pesquisa, bem como todos os terceirizados ${ }^{6}$ (limpeza, manutenção predial e segurança, entre outros) e estagiários. O público externo que utiliza esse edifício em busca de informações ou para que lhe sejam prestados determinados serviços foi considerado relevante, visto que sua representatividade perante a população fixa é significativa e o tempo em que permanecem no edifício também.

\subsection{Construção de edifícios públicos}

As obras em edifícios públicos, tanto no Brasil quanto no exterior, têm regras próprias. Os Estados Unidos, por exemplo, adotam uma prática chamada performance bond, que consiste em um seguro que a construtora deve apresentar no valor integral das obras públicas. $\mathrm{Na}$ licitação, o governo pressupõe que a empresa é idônea, não verificando o acervo técnico. A responsabilidade de avaliar o acervo e a capacidade fica a cargo da seguradora. Uma vez que a empresa não termine a obra ou tenha algum problema na execução, a responsabilidade será da seguradora, que terá que arcar com o prejuízo.

No caso da Europa, que prima pela transparência e combate à corrupção, alguns países têm códigos de ética para os funcionários públicos da área de licitações, onde a função é privilegiada e bem fiscalizada, para evitar fraudes. Outros países também adotam o critério de licitação por "obra a preço fechado", no qual a empresa vencedora deve entregar a obra de acordo com regras determinadas. Esses países não se preocupam com detalhes do orçamento ou do planejamento da execução, mas tão somente verificam os critérios pré-estabelecidos.

\subsubsection{Licitações públicas}

As obras públicas brasileiras têm regras que são determinadas pela Lei no 8.666, de 1993, que trata das licitações públicas. Por este documento legal, são definidas fases que o gestor

\footnotetext{
${ }^{6}$ No serviço público federal, as áreas passíveis de terceirização estão explícitas no Decreto Federal no 2.271, de 7/7/1997, art. $1^{\circ}$.
} 
público deve seguir, sob pena de nulidade dos atos praticados. Na Figura 4, é ilustrada a sequência natural de fases seguidas para se construir um edifício público.

O objetivo de licitar é garantir a observância do princípio constitucional da isonomia e selecionar a proposta mais vantajosa para a Administração. O projeto básico deve abranger toda a obra e possuir os requisitos estabelecidos pela Lei das Licitações, em seu art. $6^{\circ}$, IX:

- Possuir os elementos necessários e suficientes para definir e caracterizar o objeto a ser contratado;

- Ter nível de precisão adequado;

- Ser elaborado com base nos estudos técnicos preliminares que assegurem a viabilidade técnica e o adequado tratamento do impacto ambiental do empreendimento;

- Possibilitar a avaliação do custo da obra e a definição dos métodos executivos e do prazo de execução.

Figura 4 - Fases das licitações públicas

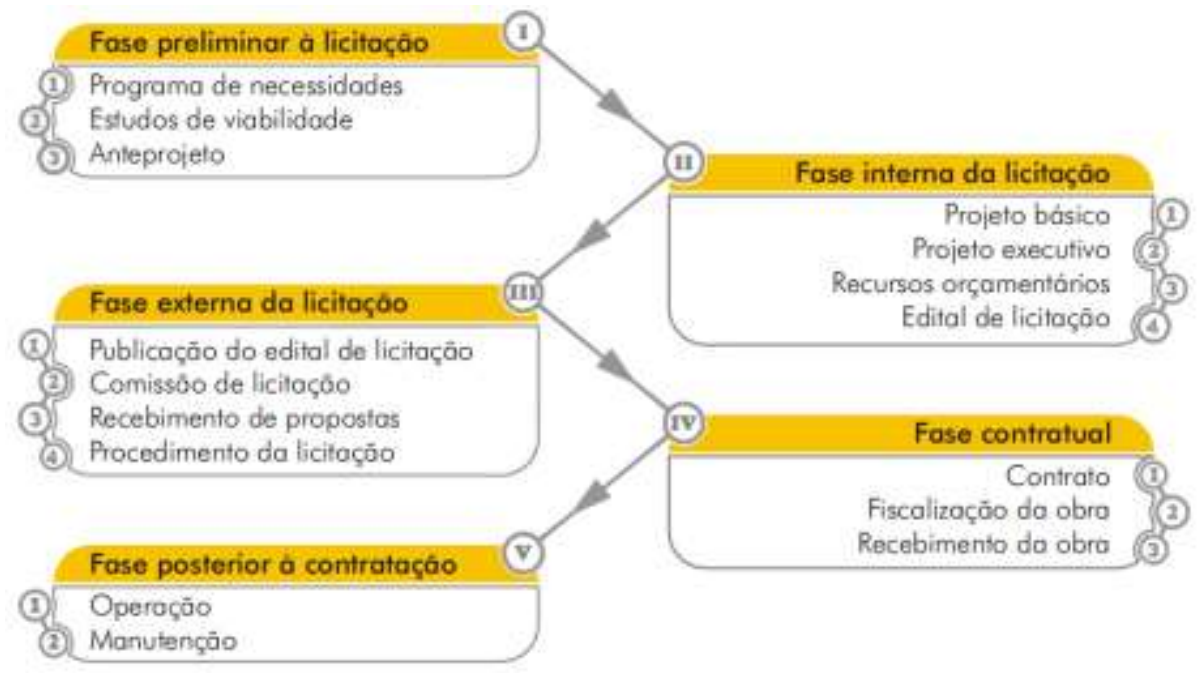

Fonte: TCU (2013)

A Lei das Licitações determina ainda que o projeto básico contenha, entre outros aspectos:

- A identificação clara de todos os elementos constitutivos do empreendimento;

- As soluções técnicas globais e localizadas;

- A identificação e especificações de todos os serviços, materiais e equipamentos a incorporar à obra;

- Orçamento detalhado do custo global da obra, fundamentado em quantitativos de serviços e fornecimentos propriamente avaliados.

Segundo o Tribunal de Contas da União - TCU (2013), é importante lembrar que a 
inconsistência ou inexistência dos elementos que devem compor o projeto básico poderá ocasionar problemas futuros de significativa magnitude, tais como:

- Alterações de especificações técnicas, em razão da falta de estudos geotécnicos ou ambientais adequados;

- Utilização de materiais inadequados, por deficiências das especificações;

- Alterações contratuais em função da insuficiência ou inadequação das plantas e especificações técnicas, envolvendo negociação de preços.

Tais problemas, circunscritos ao gerenciamento do uso da água nos edifícios públicos, podem levar a dificuldades operacionais e de execução de obras que inviabilizem programas de conservação deste insumo. Eles ocorrem em todas as fases das obras públicas e por diversas circunstâncias. Dentre os problemas específicos acerca deste assunto, podem ser exemplificados os listados no Quadro 9.

Quadro 9 - Possíveis problemas de gestão de TCAs em edifícios públicos

\begin{tabular}{|c|c|c|}
\hline Fase & Problema & Consequência \\
\hline \multirow{3}{*}{ Projeto } & $\begin{array}{l}\text { Falta de estabelecimento de critérios de } \\
\text { projeto que definam a melhor solução de } \\
\text { conservação a ser adotada. }\end{array}$ & $\begin{array}{l}\text { Adoção de solução de conservação de água } \\
\text { ineficiente para o edifício em que foi } \\
\text { implantado. }\end{array}$ \\
\hline & $\begin{array}{l}\text { Inviabilidade econômica de implantação, a } \\
\text { critério do(s) gestor(es) do órgão. }\end{array}$ & $\begin{array}{l}\text { Interrupção de processo licitatório por falta de } \\
\text { recursos orçamentários ou reprovação de } \\
\text { projeto executivo por autoridade ou ordenador } \\
\text { de despesas do órgão. }\end{array}$ \\
\hline & $\begin{array}{l}\text { Falta de competitividade no mercado, com } \\
\text { solução técnica concentrada em única ou em } \\
\text { poucas empresas. }\end{array}$ & $\begin{array}{l}\text { Dificuldade de justificativa de adoção da } \\
\text { solução perante a área jurídica do órgão. }\end{array}$ \\
\hline \multirow{3}{*}{ Execução } & Descontinuidade de produtos. & $\begin{array}{l}\text { Refazimento de especificações técnicas. A } \\
\text { depender do tempo de reestudo estipulado, } \\
\text { pode haver decisões precipitadas na escolha de } \\
\text { soluções alternativas. }\end{array}$ \\
\hline & $\begin{array}{l}\text { Mudança de especificação por conveniência } \\
\text { da administração. }\end{array}$ & $\begin{array}{l}\text { Demanda de tempo e recursos humanos para a } \\
\text { realização de estudos técnicos ou econômicos } \\
\text { que justifiquem essa mudança. }\end{array}$ \\
\hline & Retenção de recursos públicos. & $\begin{array}{l}\text { Inexecução ou interrupção da execução do } \\
\text { sistema planejado. }\end{array}$ \\
\hline \multirow{5}{*}{$\begin{array}{l}\text { Operação e } \\
\text { Manutenção }\end{array}$} & Caducidade precoce do sistema. & $\begin{array}{l}\text { Dificuldade na reposição de peças e possível } \\
\text { inoperabilidade do sistema. }\end{array}$ \\
\hline & $\begin{array}{l}\text { Falta de recursos humanos para a } \\
\text { operacionalização. }\end{array}$ & $\begin{array}{l}\text { Necessidade de ampliação da força de trabalho } \\
\text { de manutenção. Se não houver recursos para } \\
\text { tal, haverá dificuldades para realizar uma } \\
\text { manutenção adequada. }\end{array}$ \\
\hline & Tecnologia complexa. & Ausência de mão de obra capacitada. \\
\hline & $\begin{array}{l}\text { Dificuldade de reposição de peças para } \\
\text { manutenção. }\end{array}$ & $\begin{array}{l}\text { Limitação de funcionamento do sistema ou } \\
\text { inoperabilidade. }\end{array}$ \\
\hline & $\begin{array}{l}\text { Utilização errada ou inapropriada por } \\
\text { desinformação, falta de treinamento e falta de } \\
\text { conscientização. }\end{array}$ & $\begin{array}{l}\text { Aumento do número de reclamações acerca da } \\
\text { gestão e manutenção do sistema e deterioração } \\
\text { precoce dos componentes. }\end{array}$ \\
\hline
\end{tabular}


As obras públicas são regidas por um conjunto de legislações federais que não se resume às licitações públicas. Há normativos que são complementares à Lei 8.666 (1993) e que devem ser respeitados nas fases de projeto, execução e manutenção destes edifícios. Na Figura 5 constam os normativos que envolvem a construção de um edifício público.

Os gestores públicos devem estar atentos às mudanças nas legislações para que os procedimentos formais relativos a obras ocorram sem questionamentos. Em caso de cobrança de normativos ultrapassados, a possibilidade de impugnação de editais de licitação aumenta consideravelmente. A atenção ao aspecto orçamentário sempre é importante, pois há limitações impostas pela Lei de Responsabilidade Fiscal, bem como pelas leis relativas ao orçamento anual.

Figura 5 - Conjunto normativo aplicado à licitação e contratação de obras públicas

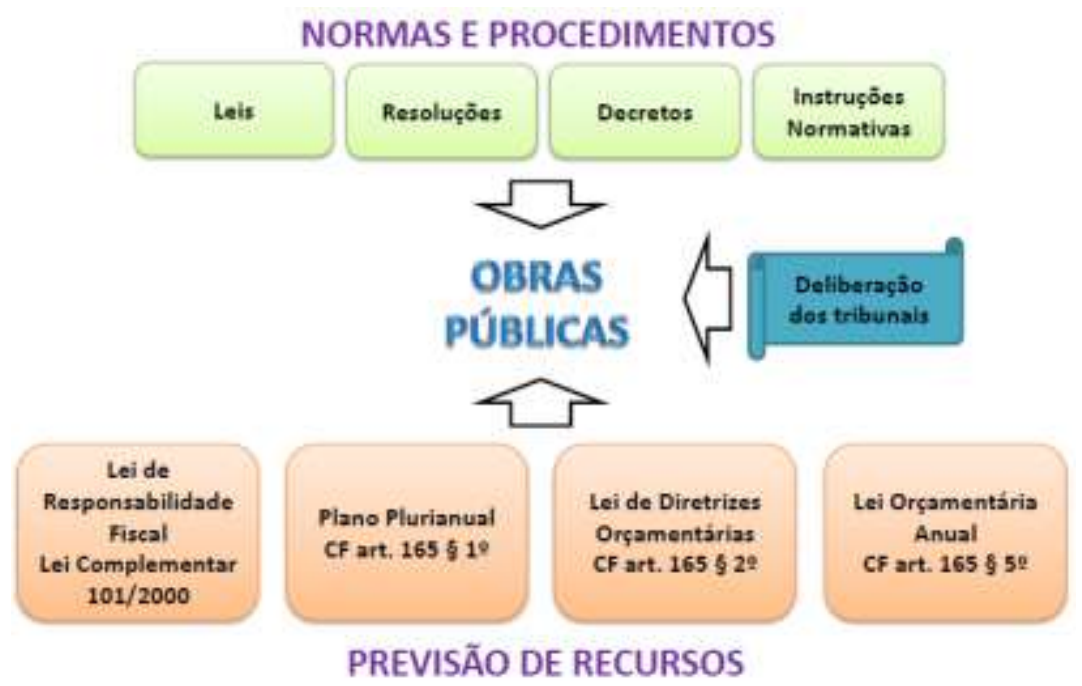

Fonte: Adaptado de Altonian (2014)

\subsubsection{Atores envolvidos}

Dentro do serviço público brasileiro, não há uma regra quanto ao envolvimento de agentes públicos nos processos vinculados à construção de edifícios públicos. A composição de equipes multidisciplinares para gerir contratos, desenvolver projetos, fiscalizar do ponto de vista técnico o andamento dos serviços ou manter em estado de uso as instalações de edifícios está diretamente relacionada à disponibilidade orçamentária do órgão, em qualquer dos poderes federais.

Carlino (2012) destaca que a melhoria constante das organizações públicas depende de rompimento de paradigmas, sendo necessária a participação da alta administração, por meio da liderança, comprometimento e dedicação. Como forma de sintetizar as responsabilidades e 
funções dos atores envolvidos na construção de edifícios públicos, foi elaborado o Quadro 10, que discrimina tais características. Os atores considerados internos são os agentes públicos que defendem os interesses do órgão, e os externos são aqueles que prestam serviços ou atuam indiretamente na execução de obras públicas, sem vínculo direto com o órgão contratante.

Quadro 10 - Características e responsabilidades de atores internos e externos envolvidos na construção de edifícios públicos

\begin{tabular}{|c|c|c|}
\hline $\begin{array}{c}\text { Atores } \\
\text { (vinculação) }\end{array}$ & Responsabilidades & Características desejáveis (perfil) \\
\hline $\begin{array}{l}\text { Diretor ou } \\
\text { Presidente do } \\
\text { órgão (interno) }\end{array}$ & $\begin{array}{l}\text { Autorização de procedimentos } \\
\text { licitatórios; análise de viabilidade } \\
\text { técnico-financeira. }\end{array}$ & $\begin{array}{l}\text { Deve possuir sensibilidade suficiente para } \\
\text { priorizar investimentos que gerem qualidade } \\
\text { em curto prazo e economia aos cofres públicos } \\
\text { em médio/longo prazos. }\end{array}$ \\
\hline $\begin{array}{l}\text { Especificador } \\
\text { (interno) }\end{array}$ & $\begin{array}{l}\text { Pesquisa de materiais; especificação } \\
\text { técnica de procedimentos; atualização } \\
\text { de normas técnicas; consolidação de } \\
\text { informações de outros profissionais } \\
\text { envolvidos. }\end{array}$ & $\begin{array}{l}\text { Célula principal do processo. Deve deter } \\
\text { conhecimento técnico compatível com sua } \\
\text { função, experiência em projetos e obras, perfil } \\
\text { gerencial desejável, conhecimento legal de } \\
\text { procedimentos licitatórios e algum poder de } \\
\text { decisão no órgão em que trabalha. }\end{array}$ \\
\hline $\begin{array}{l}\text { Projetista (interno } \\
\text { ou externo) }\end{array}$ & $\begin{array}{l}\text { Concepção do projeto; interface com o } \\
\text { especificador; conhecimento profundo } \\
\text { de materiais, técnicas e possíveis } \\
\text { interfaces entre projetos de arquitetura, } \\
\text { instalações prediais e cálculo estrutural. }\end{array}$ & $\begin{array}{l}\text { Desenvolve, em parceria com os } \\
\text { especificadores (se não forem os próprios } \\
\text { projetistas), peças que representem a } \\
\text { materialização de sua visão, sempre buscando } \\
\text { completa compatibilização das diversas áreas } \\
\text { envolvidas. }\end{array}$ \\
\hline $\begin{array}{l}\text { Representante dos } \\
\text { fabricantes } \\
\quad(\text { externo })\end{array}$ & $\begin{array}{l}\text { Atualização de informações dos } \\
\text { materiais existentes no mercado; } \\
\text { subsídio aos especificadores; } \\
\text { informação acerca de custos de } \\
\text { materiais e de mão de obra. }\end{array}$ & $\begin{array}{l}\text { Traz informações, de forma proativa, aos } \\
\text { especificadores de órgãos públicos, mantendo- } \\
\text { os atualizados. Manter informações de } \\
\text { materiais fora de linha. Manter dados } \\
\text { atualizados. }\end{array}$ \\
\hline $\begin{array}{l}\text { Fiscal da obra } \\
\text { (preferencialmente } \\
\text { interno) }\end{array}$ & $\begin{array}{l}\text { Fiscalização global da obra; } \\
\text { treinamento e disseminação de } \\
\text { conhecimentos; interface principal com } \\
\text { empresas construtoras; análise de } \\
\text { procedimentos especificados; ajuste de } \\
\text { especificações e execução de serviços } \\
\text { especificados, face às variáveis } \\
\text { inerentes a obras, dependendo de sua } \\
\text { complexidade. }\end{array}$ & $\begin{array}{l}\text { Personagem fundamental no elo dessa cadeia, } \\
\text { pois garante a implantação das premissas de } \\
\text { projeto tais quais foram pensadas, seguindo } \\
\text { diretrizes prévias de especificações, } \\
\text { verificando e controlando qualidade e } \\
\text { durabilidade dos materiais. }\end{array}$ \\
\hline $\begin{array}{l}\text { Empresa } \\
\text { Construtora } \\
\text { (externo) }\end{array}$ & $\begin{array}{l}\text { Execução da obra; treinamento de } \\
\text { funcionários; interface com o fiscal da } \\
\text { obra; busca constante de otimização de } \\
\text { custos; desejável adoção de postura } \\
\text { proativa; definição de procedimentos } \\
\text { técnicos. }\end{array}$ & $\begin{array}{l}\text { Deverá ter seu corpo técnico igualmente } \\
\text { sensível e comprometido com a questão } \\
\text { ambiental. Sua área de compras sempre deve } \\
\text { buscar seguir as recomendações técnicas de } \\
\text { projeto e indicações referenciais de } \\
\text { fabricantes. }\end{array}$ \\
\hline $\begin{array}{l}\text { Chefe de } \\
\text { manutenção } \\
\text { predial (interno) }\end{array}$ & $\begin{array}{l}\text { Desejável interface com especificadores } \\
\text { e fiscais de obra; avaliação pós- } \\
\text { ocupacional; adoção de procedimentos } \\
\text { padrão para verificação do ciclo de vida } \\
\text { dos materiais submetidos à utilização; } \\
\text { adoção de critérios e posterior sugestão } \\
\text { de recuperação. }\end{array}$ & $\begin{array}{l}\text { Pessoa importante a ser consultada, } \\
\text { especialmente se exerce a função há muito } \\
\text { tempo e conhece de perto as características } \\
\text { dos materiais e seu comportamento pós- } \\
\text { ocupação. }\end{array}$ \\
\hline
\end{tabular}


Uma marca registrada dos processos internos que envolvem as obras públicas é o papel dos responsáveis pela tomada de decisão. Neste grupo estão os agentes políticos presentes em órgãos públicos de todas as esferas e em todos os entes federados. Foi considerado que o órgão pesquisado tem autonomia para a deliberação de tais decisões, sempre respeitando as disponibilidades orçamentárias.

Os tomadores de decisão, sempre que possível, devem ser assessorados por profissionais técnicos que lhes darão subsídios suficientes para que se chegue a uma conclusão sobre uma ação. Entretanto, há que se destacarem três aspectos: o efeito perante a opinião pública, a visibilidade política do ato em si e a disponibilidade orçamentária do órgão público.

Há uma linha tênue entre o contorno político dessas ações e a habilidade do corpo técnico em convencer os tomadores de decisões a implantar tecnologias inovadoras. Segundo Barata (2007), é necessária a elaboração de planejamento integrado, envolvendo o maior número de colaboradores e áreas de trabalho, bem como a avaliação e o monitoramento do desempenho ambiental, identificando avanços e deficiências, introduzindo novas tecnologias e capacitando funcionários. A autora afirma que, para que mudanças na cultura institucional sejam efetivas, é decisivo o engajamento dos usuários e de seus dirigentes.

Com o advento do desenvolvimento sustentável, a construção de edifícios incorporando tecnologias limpas tornou-se quase que uma obrigação, especialmente em órgãos com orçamentos mais robustos. Não obstante certo excesso de propagandas enganosas na área, iniciativas para a adoção das chamadas "soluções sustentáveis" são sempre bem aceitas pela opinião pública, desde que sejam realizadas com parcerias responsáveis.

A construção dos chamados "prédios verdes" gera lucros políticos para os tomadores de decisão, que podem influenciá-los tanto positiva quanto negativamente. Seria positivo se fossem visivelmente notadas diferenças de consumo de água ou energia, sendo esses ganhos divulgados para os usuários. Seria negativo se a decisão fosse embasada em dados falsos, muito comuns em empresas que praticam o chamado green washing, que evidenciam características que em nada contribuem para a sustentabilidade do edifício.

As escolhas da equipe técnica dos órgãos públicos se mostram eficientes quando há uma pesquisa de fornecedores que possuem um histórico comprovado de responsabilidade ambiental e técnica no mercado. É também recomendável que as equipes que montarão os equipamentos ou sistemas conservadores de água sejam indicadas e/ou tenham sido treinadas 
pelos próprios fornecedores de referência. Outro fator que auxilia o tomador de decisão é a participação dos órgãos públicos em programas do governo voltados à eficiência construtiva, como a A3P.

\subsection{Gestão de obras públicas}

A fase em que mais se verificam distorções e ajustes nas especificações técnicas de edifícios públicos é a de execução da obra. Preliminarmente a ela, são gerenciadas as fases de licitação e contratação, que também devem ser executadas com toda a transparência possível e dentro de todo o arcabouço legal.

Segundo Gomes Jr (2012), a capacidade de gerir pressupõe necessariamente influência, persuasão e planejamento, bem como permeia fatores políticos, sociais, legais e econômicos para que se alcance a efetividade em suas ações.

Os fatores políticos podem ser entendidos de várias formas, como, por exemplo, na priorização de gastos públicos com obras novas em detrimento da manutenção do patrimônio edificado, o que, em consequência, deteriora o que existe e acelera a necessidade de outros gastos com reformas.

Também podem ser vistos quando da preocupação do coordenador político da instituição (presidente do órgão, diretor-geral, superintendente etc.) em relação à qualidade dos serviços prestados, especialmente no caso de órgãos que têm como base o atendimento ao público, como ocorre em escolas e hospitais. Nesse caso a imagem do edifício bem mantido gera satisfação dos usuários e bônus políticos que podem ser utilizados em momentos-chave, como, por exemplo, nas reconduções aos respectivos cargos.

Os fatores sociais e econômicos estão ligados à valorização dos profissionais envolvidos diretamente com os serviços prestados na área de manutenção e dizem respeito a valores de salários e à valorização dos trabalhadores, incorporando qualidade e dignidade ao ambiente de trabalho.

No que concerne aos edifícios públicos, é recomendável que haja um canal de comunicação constante entre as equipes do mesmo órgão envolvidas no projeto e na execução dos serviços, para que ocorram tempestivamente ponderações como, por exemplo, acerca do custobenefício dos reparos programados ou de futuros treinamentos de equipes para o melhor desempenho das soluções na fase de operação e manutenção. Eventuais omissões das equipes podem ter como consequência a perda ou o uso apenas parcial da tecnologia adotada nos 
projetos e a pequena eficiência dos sistemas, também devido à falta de qualificação e treinamento dessas equipes.

\subsubsection{Fase preliminar à licitação}

A fase preliminar à licitação envolve três etapas: o programa de necessidades, o estudo de viabilidade e o projeto básico (ou anteprojeto). No que tange ao objeto principal dessa pesquisa, a gestão de água em edifícios públicos, é importante salientar que é exatamente nessa fase que se define pela execução ou não de sistemas e equipamentos conservadores de água. No programa de necessidades, são definidas as características gerais, estimativa de usuários, padrões de acabamentos e quais são as funções principais e acessórias do edifício.

O estudo de viabilidade é o momento crucial para os tomadores de decisão dos órgãos, que são os agentes que detêm o poder decisório de se construir ou não. Por trás dessas decisões, há profissionais das áreas de construção civil, jurídica e orçamentária, que subsidiam os responsáveis pelos órgãos com informações técnicas suficientes. Segundo o TCU (2013), o estudo de viabilidade objetiva definir o empreendimento que melhor responda ao programa de necessidades, sob os aspectos técnico, ambiental e socioeconômico.

Concluídos os estudos e selecionado um programa proposto, deve-se preparar relatório com a descrição e avaliação da opção selecionada, suas características principais, os critérios, índices e parâmetros empregados na sua definição e pré-dimensionamento de ambientes.

O projeto básico de uma licitação pode ser contratado ou elaborado pelo próprio órgão. No caso de o órgão não dispor de corpo técnico especializado, ele deverá fazer uma licitação específica para contratar empresa para elaborar o projeto básico.

\subsubsection{Especificação de materiais e técnicas construtivas}

As especificações técnicas são representadas por um documento que caracteriza os materiais, equipamentos e serviços que serão utilizados na obra, visando ao desempenho técnico determinado. Devem ser as mais detalhadas possíveis, tomando sempre o cuidado de não serem rígidas o suficiente a ponto de se restringir o caráter de competitividade necessário em licitações públicas, nem tampouco genéricas demais a ponto de dar margem ao fornecimento de produtos de qualidade inferior à esperada.

A especificação técnica tem papel fundamental dentro do processo de construção de um edifício público, pois é o elo entre o projetista, o fiscal e o executor da obra. Com uma especificação de qualidade, muitas barreiras que levam ao desvirtuamento da qualidade da 
obra são rompidas. Essa fase representa o início do ciclo de vida da construção, que deve ter e seguir a mesma linguagem até a finalização da obra, bem como na manutenção do edifício.

Conforme preconiza o TCU (2013), se a referência de marca ou modelo for indispensável para a perfeita caracterização do material ou equipamento, a especificação deverá conter obrigatoriamente a expressão "ou equivalente". Cabe salientar a diferença exata entre equivalência e similaridade de materiais, conforme o Quadro 11.

Recomenda-se, no momento da execução do edifício, que a equivalência seja avaliada pela equipe de fiscalização do órgão público, antes do fornecimento efetivo, mediante apresentação do material proposto pela empresa contratada, juntamente com laudos técnicos do material ou produto ou laudos técnicos comparativos entre o produto especificado e o produto alternativo, emitidos por laboratórios autorizados pelo Instituto Nacional de Metrologia, Normalização e Qualidade Industrial (INMETRO), com ônus para a empresa construtora.

Quadro 11 - Diferença entre similaridade e equivalência de materiais

\begin{tabular}{|c|l|}
\hline Característica & \multicolumn{1}{c|}{ Definição } \\
\hline Similaridade & $\begin{array}{l}\text { Quando comparados dois materiais e definidos como similares, está simplesmente se } \\
\text { afirmando que os dois desempenham a mesma função, independentemente de } \\
\text { características de desempenho, qualidade ou acabamento. }\end{array}$ \\
\hline Equivalência & $\begin{array}{l}\text { A equivalência de materiais ocorre em relação ao atendimento aos requisitos e critérios } \\
\text { mínimos de desempenho especificados e normatizados, coincidência de aspectos visuais } \\
\text { (aparência/acabamento), de materiais de fabricação, de funcionalidade e de ergonomia. }\end{array}$ \\
\hline
\end{tabular}

Fonte: Adaptado de TCU (2013)

\subsubsection{Especificação de tecnologias conservadoras de água (TCAs)}

O uso de TCAs em edifícios públicos deve ser ponderado do ponto de vista econômico, de forma que haja a certeza do retorno dos investimentos, por meio de economia da própria água em seus usos e em seu tratamento. Igualmente importante, o aspecto técnico deverá ser pesquisado, confrontando dados disponíveis e verificando o funcionamento das tecnologias mais modernas do mercado em locais já implantados. Deve-se também colher informações com os profissionais de manutenção desses edifícios.

Como a presença de especialistas no assunto no quadro de servidores de um órgão é improvável, é recomendável a contratação de consultorias específicas para o desenvolvimento das especificações técnicas dos produtos e sistemas conservadores de água, bem como a elaboração do respectivo orçamento e de todos os detalhamentos necessários ao perfeito 
funcionamento das soluções. Sugere-se que o mesmo profissional faça o acompanhamento da obra, de forma a orientar as construtoras na perfeita execução dos serviços.

As normas técnicas que deverão ser respeitadas devem estar discriminadas, pois servirão como referência em caso de emissão de laudos para comprovação de desempenho de materiais, que devem ser bem detalhados. A descrição exata dos resultados esperados e dos cuidados na instalação dos componentes também deve ser especificada. Ao final da especificação, é necessário informar minuciosamente qual será o critério para medição dos itens descritos. Se houver falhas nesse aspecto, as construtoras muitas vezes interpretarão os textos de uma maneira distinta do órgão, o que pode gerar grandes prejuízos ao poder público.

As equipes de projeto e fiscalização, se não forem compostas pelas mesmas pessoas que desenvolveram o projeto ou que conduziram a contratação das consultorias, devem, ao menos, se comunicar a ponto de participarem das discussões para a definição de implantação ou não das TCAs na construção de edifícios públicos ou em suas reformas.

\subsubsection{Fases de contratação, execução e fiscalização}

O edital de licitação é o documento que contém as determinações e posturas específicas para determinado procedimento licitatório. $\mathrm{O}$ art. 40 da Lei $\mathrm{n}^{\circ}$ 8.666/1993 relaciona os elementos e as informações que devem constar desse documento.

O TCU (2013) afirma que é fundamental que a documentação e os aspectos concernentes ao processo de licitação sofram análise bastante criteriosa, visto que decisões tomadas nessa fase influenciarão em muito o modo de conduzir o empreendimento até sua conclusão. O edital deve ser elaborado de modo a afastar as empresas sem condições técnicas e financeiras de executar a obra, mas evitar restringir o número de concorrentes.

Conforme o TCU (2013), durante a execução de serviços e obras, cumprirá à contratada a execução das seguintes medidas, entre outras:

- Manter no local dos serviços e obras as instalações, funcionários e equipamentos em número, qualificação e especificação adequados ao cumprimento do contrato;

- Submeter à aprovação da físcalização o plano de execução e o cronograma detalhado dos serviços e obras;

- Submeter à aprovação da fiscalização os protótipos ou amostras dos materiais e equipamentos que serão aplicados nos serviços e obras objeto do contrato. 
O Manual de Obras Públicas - Edificações - Construção, da Secretaria de Estado da Administração e Patrimônio (SEAP) do Ministério do Planejamento, Orçamento e Gestão MPOG (1997), traz uma listagem não exaustiva das atribuições da fiscalização de uma obra pública. Esse mesmo manual também faz recomendações a respeito de como deve ocorrer a comunicação entre a fiscalização e a contratada.

\subsection{Manutenção de edifícios públicos}

De nada adianta a execução de obras com utilização de tecnologias modernas se não há uma equipe de manutenção predial comprometida com o conforto e a saúde dos usuários e com o funcionamento e a operacionalidade do edifício. Como já dito antes, é recomendável que a equipe de manutenção participe do projeto, opinando especialmente no que concerne às virtudes e problemas em potencial de cada TCA incorporada.

Segundo o CBIC (2013), o sistema de gestão deve equacionar tudo o que for necessário para que a manutenção predial seja realizada de maneira eficiente: planejamento, definição de responsabilidades, organização de equipes, contratações terceirizadas, previsão orçamentária para as intervenções, forma de registro das inspeções e manutenções realizadas etc.

Uma norma técnica vigente que trata do tema de manutenção predial é a NBR 14037 (2011), que discorre sobre as diretrizes para elaboração de manuais de uso, operação e manutenção das edificações e seus requisitos para elaboração e apresentação dos conteúdos.

A elaboração e a implementação do programa de manutenção corretiva e preventiva são essenciais, principalmente quanto se tornam mais complexas as edificações, afastando-se de padrões convencionais conhecidos. O manual deve apresentar recomendações para o uso racional da água, energia, gás e coleta seletiva de lixo, incluindo resíduos de construção e demolição, a fim de utilizar os recursos de forma consciente e racionalizada.

Para elaborar um plano de manutenção, tanto preventiva quanto corretiva, conforme afirma o MMA (2014), é preciso considerar as patologias mais comuns em outros edifícios públicos, bem como as principais patologias encontradas quando do levantamento em campo em sua própria edificação.

A principal norma técnica da área de manutenção é a NBR 5674 (2012), que trata dos requisitos para o sistema de gestão de manutenção, incluindo meios para preservar as características originais da edificação e prevenir a perda de desempenho decorrente da degradação dos seus sistemas, elementos ou componentes. Nesta norma, a manutenção é 
definida como "o conjunto de atividades que devem ser realizadas ao longo da vida total da edificação para conservar ou recuperar a capacidade funcional e de seus sistemas constituintes para atender às necessidades e a segurança dos seus usuários”. As principais características da manutenção, segundo a norma, estão associadas à recuperação e conservação dos edifícios.

Outro ponto importante é a obrigatoriedade de haver planejamento anual das atividades de manutenção das edificações, com utilização de processos de controle de documentação, de forma a evidenciar a realização das ações, seja pela equipe de manutenção local, empresa capacitada ou empresa especializada.

Carlino (2012) afirma que os trabalhos de manutenção nos edifícios públicos objetos de sua pesquisa são corretivos em sua grande maioria, não existindo de forma bem definida planos de manutenção predial voltados à prevenção.

Segundo a NBR 5674:2012, a organização da gestão do sistema de manutenção deve considerar as características das edificações, tais como tipologia, uso efetivo, tamanho e complexidade das edificações, bem como a localização e implicações do seu entorno. Segundo essa norma, os tipos de manutenção são classificados conforme o Quadro 12.

Quadro 12 - Tipos de manutenção preditiva e suas características principais

\begin{tabular}{|c|c|c|}
\hline $\begin{array}{c}\text { Tipo de } \\
\text { manutenção }\end{array}$ & Característica & Exemplo \\
\hline Rotineira & Fluxo constante de serviços simples, padronizados e cíclicos. & $\begin{array}{c}\text { Limpeza geral e lavagem de } \\
\text { áreas comuns. }\end{array}$ \\
\hline Corretiva & $\begin{array}{c}\text { Permite a continuidade do uso dos sistemas, elementos ou } \\
\text { componentes das edificações ou evita graves riscos ou prejuízos } \\
\text { pessoais e/ou patrimoniais aos seus usuários ou proprietários. }\end{array}$ & $\begin{array}{c}\text { Serviços que demandam } \\
\text { ação ou intervenção } \\
\text { imediata. }\end{array}$ \\
\hline Preventiva & $\begin{array}{c}\text { Solicitações dos usuários, estimativas da durabilidade esperada } \\
\text { ou verificações periódicas sobre o estado de degradação dos } \\
\text { sistemas, elementos ou componentes em uso nas edificações. }\end{array}$ & $\begin{array}{c}\text { Serviços cuja realizaçá é } \\
\text { programada com } \\
\text { antecedência. }\end{array}$ \\
\hline
\end{tabular}
Fonte: NBR 5674:2012

Além das normas técnicas da ABNT, outra referência para a administração pública é o Manual de Obras Públicas - Edificações, da extinta Secretaria de Estado da Administração e do Patrimônio (SEAP), conhecido como Manual de Práticas SEAP (1997). Em seu caderno específico de Práticas de Manutenção, recomenda-se que a periodicidade dos serviços da área de instalações hidrossanitárias seja estabelecida em função da intensidade de uso das instalações e componentes, condições locais, experiência do contratante e recomendações dos fabricantes e fornecedores.

No mesmo Manual SEAP, há orientações no que tange às atividades que devem ser desempenhadas na fiscalização dos contratos de manutenção, com questões relativas ao 
acompanhamento dos serviços, ao controle de qualidade e à organização da sequência de serviços demandados. Há também menção expressa aos procedimentos de medição e recebimento de serviços, alertando para o cuidado que o fiscal deve ter nas inspeções, na exigência de entrega de relatórios periódicos e no pagamento dos serviços.

Quando se trata de reforma que contemple sistemas de conservação de água, há que se considerar o conteúdo do Decreto Federal n 7.746 (2012), cujo escopo autoriza os órgãos a contratar serviços e obras considerando critérios e práticas de sustentabilidade.

A adoção de critérios e práticas de sustentabilidade deverá ser justificada e preservar o caráter competitivo da contratação. Nesse caso, as especificações e demais exigências do projeto básico ou executivo para contratação de obras e serviços de engenharia deverão ser elaboradas de modo a proporcionar a economia da manutenção e operacionalização da edificação e a redução do consumo de energia e água, por meio de tecnologias, práticas e materiais que reduzam o impacto ambiental.

\subsection{Síntese analítica do capítulo 1}

Verifica-se neste capítulo, por toda bibliografia consultada, que há uma necessidade de disseminação de boas práticas na cultura de consumo da água. O Brasil já possui uma legislação robusta o suficiente para provocar essa mudança. A conscientização ocorre por duas frentes: uma em cada residência, no momento de cada uso, por força da necessidade ou do sentimento de cooperação para com o próximo, em qualquer escala, seja a vizinhança, a cidade ou o país; a outra vem de o Poder Público impor, aos poucos, um regramento que seja planejado para ser eficiente como vetor de mudanças.

Os edifícios públicos e seus usuários têm um potencial enorme para serem disseminadores de ações para esse novo patamar de consciência de uso da água. O propósito dessa pesquisa, em parte, é de trazer este tema à tona. A primeira pergunta que se faz é: a legislação brasileira está consolidada o suficiente para promover a disseminação de PCAs nos edifícios públicos?

Para responder a essa pergunta, devemos tomar como base as recomendações discriminadas na legislação brasileira para os edifícios públicos (Lei de Licitações e Práticas SEAP, especialmente), acrescentando à análise a legislação que trata de gestão de água (PNRH, Resoluções CNRH e normas ABNT) e os passos recomendados em ANA et al. (2005) e MMA (2014). 
Nesta miscelânea legal e orientativa, é possível afirmar que temos instrumentos suficientes para o sucesso na implantação de PCAs em edifícios públicos, pois:

- A legislação brasileira já prevê o uso de água de menor qualidade em sistemas específicos nos edifícios, de forma a reduzir a oferta deste insumo;

- Há exemplos fartos de legislação estadual e municipal que incentiva tais usos e a conservação de água em edifícios, inclusive públicos. Faltam iniciativas de governos estaduais e associações de municípios para divulgar e incentivar outros legisladores na discussão desse tema;

- Há normatização específica para as TCAs, já citadas neste capítulo, especialmente as NBRs 13969:1997 e 15527:2007;

- Houve um grande avanço na área de licitações públicas com a publicação do Decreto Federal 7.746/2012, que dá maior liberdade aos órgãos de especificar soluções técnicas em obras com foco na sustentabilidade. Entre essas soluções está o uso eficiente da água;

- Há legislação que incentiva a eficientização dos edifícios, como a IN 2/2014 - MPOG, que determina a adoção do selo "A" do programa Procel Edifica como referência de eficiência energética, que dá bonificações para a eficiência hídrica.

Entretanto, temos também barreiras a transpor neste mesmo assunto, como, por exemplo:

- Necessidade de rompimento de paradigmas e mudanças na cultura institucional, sendo importante a participação da alta administração e engajamento dos usuários dos edifícios públicos, conforme afirmam Carlino (2012) e Barata (2007). Resta, portanto, uma divulgação maciça nos órgãos públicos para que seus especificadores e fiscalizadores exijam qualidade técnica de execução dos edifícios públicos, transpondo essa mudança de cultura para os setores de serviços e industrial, com maior oferta de produtos e soluções sustentáveis;

- Falta de critérios objetivos para comprovação de viabilidade técnica, ambiental e socioeconômica nas obras públicas, segundo recomendações do TCU (2013). Nesse ponto, as metodologias de ANA et al. (2005) e MMA (2014) contemplam esse estudo de viabilidade, mas não há uma definição objetiva informando um indicador confiável em que a implantação de PCAs seja considerada viável;

- Não há uma fiscalização eficiente atuando na gestão de uso da água dos entes públicos, pois há poucos órgãos de controle para uma grande quantidade de municípios, além de o foco ser maior na gestão financeira que na administrativa. Entretanto, é possível que esse 
cenário se modifique com a publicação da Portaria no 23 do MPOG (2015), já que haverá dados primários disponíveis de muitas instituições públicas acerca do consumo de água.

O arcabouço legal existente para o setor público é apenas permissivo quanto à adoção de determinadas soluções e impositivo em outras, conforme discriminado em Blumenschein (2004). A depender do gestor, a legislação faculta que sejam adotadas posturas inovadoras (ver Quadro 5, p. 47), mas a priorização dos gastos e a corrupção presente em administrações públicas impedem a disseminação e efetivação dessas ideias.

Dado isso, uma das recomendações dessa pesquisa é a de desenvolvimento de novos estudos acerca da imposição de normativos que exijam a redução constante de consumo de água em edifícios públicos, baseados em indicadores nacionais, bem como a separação de rubricas orçamentárias próprias para investimento em ações de eficiência de desempenho de edifícios.

Uma das causas da dificuldade de quebrar paradigmas entre os gestores públicos pode ser a adoção de poucas iniciativas de forma preventiva. Em muitos casos, as ações são paliativas ou emergenciais, devido a problemas de escassez ou má gestão de contratos de manutenção predial. Dados da Associação Brasileira de Manutenção - ABRAMAN (2013) registram que a aplicação dos recursos das empresas de manutenção foi distribuída da seguinte forma: manutenção preventiva $(36,55 \%)$, corretiva $(30,86 \%)$ e rotineira $(18,82 \%)$, demonstrando que a prevenção tem ainda muito espaço para avançar.

Outra recomendação que se pode extrair deste trabalho é a da necessidade de se incentivar gestores públicos federais a desenvolver pesquisas de opinião anuais para obter o respaldo dos usuários das instalações públicas acerca da qualidade de vida no ambiente de trabalho, do desempenho da gestão predial e de ideias para o aprimoramento da administração. Essas iniciativas fazem com que todos os usuários sintam que têm uma parcela de responsabilidade no cuidado com o dinheiro público e que podem atuar como elo numa corrente em busca de excelência na prestação de serviços públicos.

Espera-se que os órgãos públicos cada vez mais sejam provocados a participar desta mudança, mesmo que de forma compulsória, fomentando a participação do público interno e externo a contribuírem como agentes dessa nova postura. Os edifícios públicos, por sua representatividade, têm todo o potencial para serem exemplos para a sociedade brasileira na cultura da economia de água e da qualidade ambiental dos espaços de trabalho. 
O que se percebe, pela literatura consultada neste capítulo, é que ainda há pouco interesse no assunto, tendo em vista a dificuldade de obtenção de dados precisos de consumo de água e a legislação que ainda necessita de avanços, o que provoca dificuldades operacionais para se inserir, nas matrizes de gestão predial, as inovações tecnológicas necessárias. Esta percepção tem base nos seguintes dados:

- Mudanças pontuais na Lei nº 8.666/1993 (Lei de Licitações Públicas) têm sido discutidas no Congresso Nacional há anos, mas a priorização de temas políticos leva tais assuntos a segundo plano, mesmo com a relevância deste tema;

- Os limites de valores para as modalidades de licitação são os mesmos há 17 anos, provocando descompasso entre o mercado e a administração pública. Esse engessamento provoca maior burocratização de procedimentos, falta de celeridade na gestão predial e desmotivação de agentes públicos;

- A cultura do menor preço como vantagem para a administração pública leva à aquisição de bens e à execução de obras públicas, em alguns casos, de baixa qualidade, gerando grandes dificuldades de fiscalização e maiores gastos com manutenção;

- Não há legislação compulsória para a execução de PCAs, mas somente recomendações (ANA e MMA) e regulamentos autorizativos (Decreto 7.746/2012 e IN 10/2012).

É recomendado, portanto, que essas dificuldades devam ser minimizadas desde a sua origem, por exemplo, com a programação de palestras e cursos que esclareçam aos usuários dos edifícios os benefícios de medidas conservadoras de água. Os projetistas devem ter consciência do ganho ambiental e econômico de implantação de TCAs e os responsáveis pela manutenção devem acompanhar de perto esses avanços, trabalhando em parceria, para colher os frutos no momento da gestão de contratos da manutenção predial.

No caso de incorporação de alguma TCA no projeto, recomenda-se também que a equipe formada (própria ou contratada) realize pesquisas prévias e detalhadas de fornecedores idôneos e que possuam soluções com vantagens comprovadas em relação à eficiência dos produtos ou sistemas. É recomendável ainda que se contatem outros órgãos públicos que já aplicaram alguma dessas tecnologias e que se busquem informações acerca da confiabilidade, operacionalização e economia de água.

No que concerne à fiscalização e execução de obras e reformas, recomenda-se maior controle e fiscalização no fornecimento dos insumos, partindo do pressuposto que serão bem especificados. A execução tem que ser precisa e seguindo as recomendações dos fabricantes. 
Exigências de laudos que atendam às normas técnicas e de testes detalhados para a verificação do funcionamento das TCAs também são importantes.

Exigências de qualificação técnico-profissional, técnico-operacional e financeira das empresas interessadas, por meio de critérios objetivos, bem como a transparência dos atos e decisões tomadas pelos órgãos públicos e ajustes dos percentuais exigíveis para desclassificação de empresas nas licitações são algumas das ponderações discutidas por Ponte (2015) para aprimoramento da Lei de Licitações. Tais ajustes garantem a execução de serviços de qualidade, com melhores resultados futuros dos sistemas de conservação de água implantados. Sabe-se que a vida útil dos edifícios é finita, assim como que, com medidas de manutenção e conservação adequadas, essa vida útil tende a se prolongar. A administração pública brasileira, quando da necessidade de reformas de edifícios, deverá, sempre que possível, procurar rever a tecnologia aplicada de seus sistemas, de modo que possa modernizar seu parque edificado, utilizando, no caso do uso da água, tecnologias e sistemas conservadores. 


\section{CAPÍTULO 2 - TECNOLOGIAS CONSERVADORAS DE ÁGUA}

Por definição, de acordo com Tomaz (2010), a American Water Works Association (AWWA) considerou, há mais de vinte anos, a conservação da água como o conjunto de práticas, tecnologias e incentivos que aperfeiçoam a eficiência do uso da água. Vickers (2001) considera que as estratégias conservadoras de água devem ser utilizadas como ferramentas específicas (tecnológicas) e práticas (mudança de postura do usuário), que resultam no uso mais eficiente da água, sendo as primeiras mais confiáveis para a obtenção de economia e controle sobre o consumo de água.

Para se avaliar a demanda a água, conforme explica Gonçalves (2007), é necessária a avaliação do consumo de água existente e das intervenções necessárias para otimização do consumo, bem como a minimização de vazamentos. Para tanto, devem-se detectar as perdas físicas do sistema, os processos e sistemas que utilizam água, os equipamentos hidráulicos e a pressão hidráulica do sistema.

Oliveira (1999) e Giacchini (2011) entendem que a gestão da água pode ser adotada em três níveis de abordagem:

- Macro, que está associado às ações na escala dos grandes sistemas ambientais e bacias hidrográficas;

- Meso, que implica ações nos sistemas de saneamento, envolvendo os serviços de saneamento e esgotamento sanitário; e

- Micro, que está relacionado às ações que se concentram sobre as edificações e seus sistemas prediais hidrossanitários.

O escopo deste trabalho se limita à conservação dos sistemas vinculados às edificações, partindo sempre do pressuposto que as edificações públicas estão com seus sistemas públicos de abastecimento de água e de esgotamento sanitário funcionando perfeitamente.

O Conselho Brasileiro de Construção Sustentável - CBCS (2010) considera, de forma ampla, que a conservação de água apresenta dimensões de base ambiental, social e econômica. Sob a ótica ambiental, a implantação de ações de conservação de água traz como consequência a preservação dos recursos hídricos, favorecendo o desenvolvimento sustentável. Na questão social, viabiliza a melhor distribuição dos recursos hídricos aos usuários finais, através dos volumes excedentes obtidos. Sob a ótica econômica, reduz os custos relativos aos insumos, além de gerar racionalização dos custos relativos à manutenção e operação dos sistemas. 
Quando se trata da gestão da água em uma edificação, o CBCS a associa a duas componentes fundamentais:

- Técnica: engloba as ações de avaliações, medições, aplicações de tecnologias e procedimentos para o uso da água;

- Humana: envolve comportamentos e expectativas sobre o uso da água e procedimentos para realização de atividades consumidoras.

A Organização Mundial da Saúde estabelece o consumo mínimo per capita de 100 litros por dia, que representa o suficiente para uma pessoa saciar sua sede, ter uma higiene adequada e preparar os alimentos. No Brasil, o Ministério das Cidades (2014) calculou que a média diária de consumo de água por indivíduo no Brasil é de 167,5 litros, baseados no consumo doméstico, comercial, público e industrial. A esse consumo, o documento acrescenta o índice de perdas na distribuição de água, que chega a ser de $36,9 \%$ do total.

Como comparação, as perdas de alguns países europeus em 2007, segundo Tomaz (2010), foram as seguintes: Albânia - 75\%, Bulgária - 60\%, Ucrânia - 50\%, Hungria - 40\%, França - 30\%, Itália - 30\%, Espanha - 22\%, Reino Unido - 17\%, Dinamarca - 16\%, Finlândia $15 \%$, Alemanha $-8,8 \%$.

Entre os motivos para as perdas de água nas cidades estão as falhas na detecção de vazamentos, pressões elevadas nas redes de distribuição, problemas na operação dos sistemas, dificuldade tanto no controle das ligações clandestinas quanto na aferição/calibração dos hidrômetros e ausência de programas para monitoramento de perdas. Gonçalves (2009) alerta que não se pode confundir perda com desperdício. Este último corresponde à negligência do usuário que não tem consciência ambiental, tanto no uso propriamente dito quanto no funcionamento geral do sistema hidráulico, mais evidente na escala das edificações.

Conforme Gonçalves (2007), na gestão de conservação de água em edifícios, deve-se dar atenção especial ao desempenho e produtividade, com enfoque sistêmico no desenvolvimento de sistemas e componentes, por meio de sua integração com métodos construtivos racionalizados, do uso de modelos de projeto dos sistemas prediais e da busca constante de novos componentes e equipamentos.

Entre as tecnologias de gerenciamento do uso da água nas edificações, de acordo com Giacchini (2011), estão incluídos, entre outras, o uso racional por meio de aparelhos 
economizadores de água e o uso de fontes alternativas de abastecimento de água para fins não potáveis, como a água cinza e a água de chuva.

Um estudo encomendado pela União Europeia e publicado em agosto de 2007 estima que a eficiência no uso da água possa ser melhorada em quase $40 \%$ por meio de melhorias tecnológicas pontuais, como a introdução de equipamentos economizadores. De acordo com Dworak et al. (2007), com a adição do aproveitamento de águas pluviais e o reúso de águas cinzas, esse valor tende a dobrar.

Para efeito deste trabalho, portanto, as tecnologias conservadoras de água (TCAs) referem-se ao conjunto de soluções aplicáveis ao gerenciamento dos sistemas prediais de um edifício que primam pelo uso racional da água. Foram estudadas as TCAs mais encontradas na literatura: a hidrometração unitária, os equipamentos economizadores de água (EEAs), os sistemas de aproveitamento de águas pluviais (AAPs) e os sistemas de tratamento de águas cinzas (TACs) e águas residuárias (TARs), estas últimas também chamadas na literatura de águas recicladas ou reaproveitadas. Outras TCAs existentes não foram incorporadas a esta pesquisa.

Segundo a ANA (2005), a análise das possibilidades de aplicação de fontes alternativas de água deverá considerar os níveis de qualidade da água necessários, as tecnologias existentes, cuidados e riscos associados à aplicação de "água menos nobre" para "fins menos nobres" e a gestão necessária durante a vida útil da edificação. Além disso, os custos envolvidos na aquisição das tecnologias e ao longo da gestão deverão ser levantados durante a concepção das soluções.

Segundo Kalbusch e Gonçalves (2007), podem-se agrupar os seguintes itens de avaliação dos sistemas prediais hidráulicos e do uso da água nos seguintes requisitos:

- Confiabilidade, qualidade e manutenibilidade dos sistemas prediais hidrossanitários;

- Saúde e qualidade da água;

- Gestão da demanda de água;

- Gestão da oferta de água (sistemas AAP, TAC e TAR);

- Carga na infraestrutura local (drenagem pluvial e tratamento de esgotos);

- Interferência dos edifícios nos aquíferos subterrâneos;

- Qualidade dos materiais e componentes hidráulicos aplicados.

Cabe salientar ainda a necessidade da identificação apropriada dos diferentes sistemas prediais que transportam água, principalmente com a complexidade de diferenciação dos 
sistemas de água potável e de não potável. Os riscos e falhas que podem existir no projeto, execução e manutenção são elevados, e o resultado de uma falha pode causar danos graves aos usuários finais, bem como aos sistemas. A NBR 13969 (1997) recomenda a identificação dos sistemas de reserva e distribuição de água de reúso, a sinalização das tubulações com cores distintas e vinculação a algum regramento internacional, como o Guidelines for Water Reuse (2012), que recomenda a pigmentação da água não potável.

Segundo o CBCS (2010), na gestão da demanda da água, conforme esquematiza a Figura 6, é importante que sejam detalhados procedimentos específicos para as atividades consumidoras, cujos conteúdos possam facilmente ser transmitidos aos usuários envolvidos nas atividades. Muitas vezes os ajustes para redução do desperdício são relativos aos aspectos comportamentais e não somente a adequações tecnológicas.

Com relação à adequação de equipamentos hidráulicos, os mesmos devem ser especificados de acordo com a pressão de utilização e o tipo de uso e de usuário do ponto de consumo, devendo proporcionar conforto ao usuário e minimizar o consumo de água. Deve ainda ser avaliado se a pressão disponível no sistema hidráulico é apropriada ao desempenho das atividades consumidoras e funcionamento dos equipamentos hidráulicos. O controle da pressão também pode representar importante contribuição para a redução do consumo de água.

Figura 6 - Esquema de ações para a gestão da demanda de água

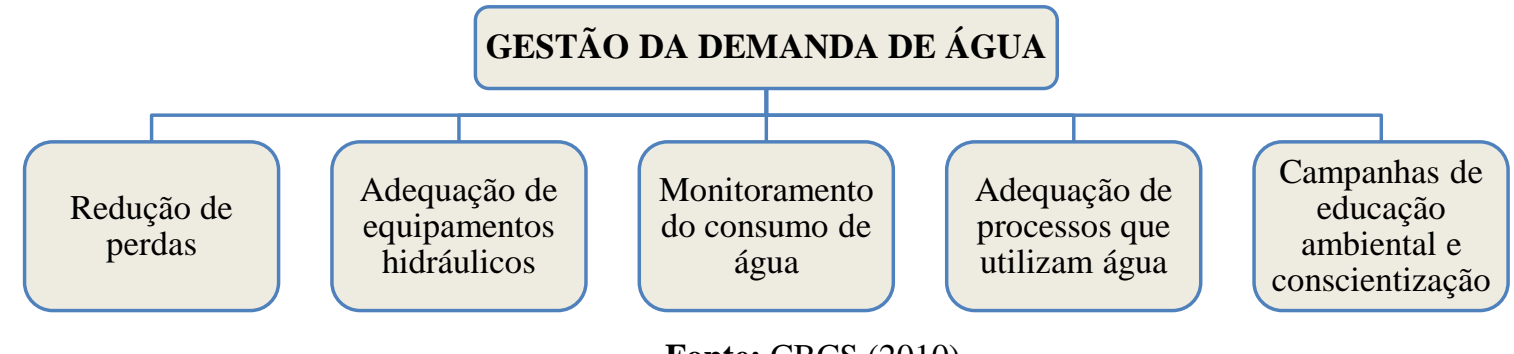

Fonte: CBCS (2010)

Dentre as ações de um programa de conservação de água, de acordo com ANA et al. (2005), o combate ao desperdício é de fundamental importância. Define-se desperdício como toda a água que está disponível em um sistema e não é utilizada, advinda da junção de perdas e uso excessivo, sendo que ambos podem ser decorrentes do mau desempenho do sistema, em que a água é utilizada sem que desta se obtenha algum benefício, como é o caso dos vazamentos; ou negligência e procedimentos inadequados do usuário, especialmente por descaso quanto à necessidade de sua preservação (OLIVEIRA, 1999). 
A detecção e o reparo de vazamentos são as primeiras ações indispensáveis para qualquer implantação de um programa de redução de consumo de água. De acordo com Hafner (2007), os vazamentos ocorrem por diversos fatores. Entre eles destacam-se, principalmente, o desgaste natural de sistemas hidráulicos antigos e as instalações hidráulicas mal instaladas.

A mesma autora afirma que esses testes podem ser feitos pelo próprio usuário, simplesmente fechando registros e verificando equipamentos, como o relógio do hidrômetro e o nível na caixa de água. Um grande aliado dos vazamentos não visíveis em sistemas de maior porte é o detector eletrônico de fugas, que é acoplado ao hidrômetro, como exemplificado na Foto 1. Como exemplo, em Londres, tal dispositivo reduziu em $20 \%$ as perdas de água nas instalações domésticas.

Foto 1 - Detector eletrônico de fugas d'água

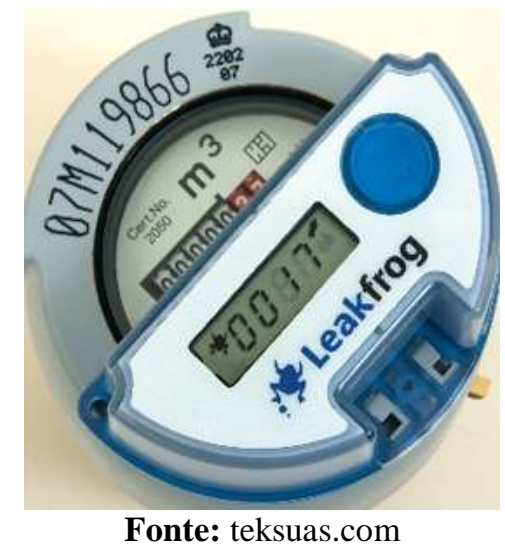

É de fundamental importância, por exemplo, a correção de vazamentos antes da substituição de componentes convencionais por economizadores de água, como forma de evitar resultados enganosos. Além disso, o permanente controle de desperdícios no sistema tende a deixá-lo o mais próximo de suas condições plenas de desempenho. No caso de sistemas hidráulicos especiais, a redução de perdas é obtida por meio da manutenção adequada, evitando-se as perdas por vazamento, mau desempenho do sistema ou por negligência da manutenção.

Para se ter uma ideia da importância desse tema, Oliveira (2002) afirma que os desperdícios de água de torneiras podem variar de 6 litros/dia, no caso de gotejamento lento, até mais de 300 litros/dia, no caso de formação de um filete de diâmetro de $4 \mathrm{~mm}$. A Tabela 1 mostra os volumes estimados perdidos em vazamentos para cada tipo de equipamento sanitário.

Um excelente exemplo de sucesso de conservação de água no Brasil, que focou, dentre suas ações, a correção de vazamentos, foi o Programa de Uso Racional de Água (PURA-USP), que conseguiu, a partir de 1998, reduzir significativamente o consumo de água da instituição, a 
maior consumidora da empresa de saneamento. Antes do programa, o consumo de água no campus era de $137 \mathrm{mil} \mathrm{m}$ /mês e representava um custo com água de $\mathrm{R} \$ 1,46$ milhão por mês para a USP, que, assim como outras instituições públicas, não conseguia pagar. Hoje esse volume estabilizou-se e apresenta uma redução por volta de 43\%, chegando aos 79 mil $\mathrm{m}^{3} / \mathrm{mês}$.

Tabela 1 - Volumes de água estimados perdidos em vazamentos

\begin{tabular}{|c|c|c|}
\hline Aparelho / Equipamento sanitário & Característica & Perda estimada \\
\hline \multirow{7}{*}{$\begin{array}{c}\text { Torneiras (de lavatório, de pia, de } \\
\text { uso geral) }\end{array}$} & Gotejamento lento & 6 a 10 litros/dia \\
\hline & Gotejamento médio & 10 a 20 litros/dia \\
\hline & Gotejamento rápido & 20 a 32 litros/dia \\
\hline & Gotejamento muito rápido & > 32 litros/dia \\
\hline & Filete $\emptyset 2 \mathrm{~mm}$ & $>114$ litros/dia \\
\hline & Filete $\emptyset 4 \mathrm{~mm}$ & $>333$ litros/dia \\
\hline & Vazamento no flexível & 0,86 litros/dia \\
\hline \multirow{3}{*}{ Mictório } & Filetes visíveis & 144 litros/dia \\
\hline & Vazamento no flexível & 0,86 litros/dia \\
\hline & Vazamento no registro & 0,86 litros/dia \\
\hline \multirow{3}{*}{$\begin{array}{l}\text { Bacia sanitária com válvula de } \\
\text { descarga }\end{array}$} & Filetes visíveis & 144 litros/dia \\
\hline & $\begin{array}{l}\text { Vazamento no tubo de } \\
\text { alimentação da louça }\end{array}$ & 144 litros/dia \\
\hline & $\begin{array}{l}\text { Válvula disparada quando } \\
\text { acionada }\end{array}$ & $\begin{array}{l}\text { 40,8 litros (supondo a válvula } \\
\text { aberta por um período de } \\
\text { trinta segundos, a uma vazão } \\
\text { de } 1,6 \text { litros/segundo) }\end{array}$ \\
\hline \multirow[b]{2}{*}{ Chuveiro } & Vazamento no registro & 0,86 litros/dia \\
\hline & $\begin{array}{c}\text { Vazamento no tubo de } \\
\text { alimentação junto da parede }\end{array}$ & 0,86 litros/dia \\
\hline
\end{tabular}

Fonte: Oliveira (2002)

O resultado, após quinze anos de trabalho contínuo, é claramente visualizado pela redução no valor do gasto anual com água (1998/2013): queda de R \$ 49,3 milhões ${ }^{7}$ para R \$ 18,1 milhões e redução de $48 \%$ na demanda per capita, passando de 111 litros/pessoa/dia para 57 litros/pessoa/dia.

Outro exemplo é o relatado em Silva et al. (2014), que, em seu estudo, pesquisou por cinco anos o comportamento de 17 (dezessete) edifícios públicos administrativos em Salvador. O Governo do Estado e a Universidade Federal da Bahia estabeleceram uma parceria por meio do Programa de Uso Racional da Água e Energia. Entre as ações implantadas, destacam-se, entre outras, a preparação de procedimentos para a detecção e reparos de vazamentos, o treinamento de Ecoteams e a desativação de espelhos d'água. As ações e procedimentos implantados até agora permitiram uma redução de mais de $270 \mathrm{mil} \mathrm{m}^{3}$ em consumo de água

\footnotetext{
${ }^{7}$ Valores atualizados de 1997 para 2013. O desconto de 25\% na tarifa de água representa 19\% da diferença.
} 
entre junho de 2008 e dezembro de 2013, o que equivale a uma redução de cerca de $30 \%$ quando comparado com o ano base.

As TCAs, se implantadas em prédios públicos, deverão ser propostas de maneira gradativa, compondo-se a economia gerada com os custos de aquisição. A eficiência futura do uso da água será determinada pelo usuário e pela gestão do insumo ao longo da vida útil da edificação.

\subsection{Hidrometração unitária}

O primeiro questionamento a ser feito, segundo a ANA (2005), na montagem de um Programa de Conservação de Água de um edifício diz respeito à medição do consumo de água. O método mais preciso para tanto é a hidrometração unitária, que consiste na instalação de hidrômetros em unidades-padrão dos edifícios (COELHO e MAYNARD, 1997).

Os objetivos buscados no uso de hidrometração unitária são:

- Economia de água entre 20\% e 30\% [31,72\% (COELHO, 2004); 29,89\% (HOLANDA, 2007) ${ }^{8} ; 36,52 \%$ (SOUZA FILHO et al., 2005); 22,1\% (SILVA, 2010)];

- Redução do volume efluente de esgotos com benefícios ecológicos e econômicos;

- Redução do desperdício de água e do consumo de energia elétrica pela redução do volume bombeado para reservatórios elevados, bem como redução na manutenção das bombas de recalque, se for o caso;

- Identificação de vazamentos de difícil percepção;

- Maior controle das contas e do consumo das unidades medidas.

No caso de edifícios residenciais, cada apartamento recebe um medidor, enquanto que, em edifícios comerciais, a separação se dá pelo escritório de cada empresa instalada. Os edifícios públicos administrativos, entretanto, não têm uma unidade bem definida, pois, na maioria dos casos, têm pontos coletivos de consumo e as unidades de área de escritórios têm o consumo de água diluído nesses locais de uso comum.

Cabe ressaltar que, quando se trata de edifícios públicos, a hidrometração unitária é recomendada especialmente para fins de controle de demanda, pois não cabem cobranças separadas por unidades de consumo (andares ou prumadas, por exemplo). Essa separação pode acontecer em caso de compartilhamento de edifícios por mais de um órgão ou

\footnotetext{
${ }^{8}$ Percentual médio de economia dos três edifícios estudados.
} 
necessidade, por força contratual, de responsabilização pela conta de água, como no caso de lanchonetes e restaurantes que prestam serviços dentro dos órgãos.

Tendo em vista a conformação dos edifícios públicos, a hidrometração deve ser dividida em setores ou andares, em áreas de maior concentração de ambientes com instalações hidráulicas, de forma a considerar o consumo de um grupo de usuários. Tamaki (2003) entende que a medição setorizada é um importante instrumento para a gestão da demanda de água. No que tange à normatização internacional, destacam-se as normas descritas no Quadro 13.

Quadro 13 - Exemplos de normatização internacional de hidrometração unitária

\begin{tabular}{|c|c|l|}
\hline País & Norma & \multicolumn{1}{c|}{ Características } \\
\hline Alemanha & $\begin{array}{c}\text { DIN 1988-200 } \\
\text { revisada em 2012) }\end{array}$ & $\begin{array}{l}\text { Define que em edificações residenciais multifamiliares deve-se prever } \\
\text { a instalação de um hidrômetro para cada unidade habitacional. }\end{array}$ \\
\hline Portugal & $\begin{array}{c}\text { NP 4001/1991 } \\
\text { art. 106 } \\
\text { Contadores de água } \\
\text { potável fria }\end{array}$ & $\begin{array}{l}\text { Obrigatória a instalação de um hidrômetro para cada consumidor de } \\
\text { unidades residenciais. Norma substituída por uma de abrangência em } \\
\text { toda a Comunidade Europeia, a NP EN 14154-1+A2, de 2014. }\end{array}$ \\
\hline Estados Unidos & $\begin{array}{c}\text { Legislação dos } \\
\text { estados do } \\
\text { Colorado, Arizona, } \\
\text { Nova York, Idaho e } \\
\text { Califórnia }\end{array}$ & $\begin{array}{l}\text { A individualização não é um consenso entre os estados, mas é } \\
\text { opcional sua instalação, sempre por telemetria. Economia média de } \\
15,3 \% \text { em relação ao período sem individualização. Estima-se que, } \\
\text { até o ano de 2040, a utilização de hidrometração unitária atinja entre } \\
30 \% \text { a 50\% da população urbana dos EUA. A recomendação desse } \\
\text { tipo de instalação é para edifícios residenciais, comerciais e mistos, } \\
\text { com data loggers instalados a cada três pavimentos. }\end{array}$ \\
\hline Austrália & $\begin{array}{c}\text { ATS 4747 - } \\
\text { National Standards }\end{array}$ & $\begin{array}{l}\text { Obrigatória a instalação de individualização em todas as edificações } \\
\text { residenciais coletivas e mistas (residenciais e comerciais) da cidade } \\
\text { de Sidney, desde setembro de 2014. A tecnologia empregada é a de } \\
\text { telemedição sem fios, com data loggers implantados, no máximo, a } \\
\text { cada cinco pavimentos construídos. }\end{array}$ \\
\hline
\end{tabular}

Fontes: Coelho (2004); Mayer et al. (2004); Alliance for Water Efficiency (2008); Sidney Water (2014)

A legislação brasileira é bem difundida quando se trata do tema de hidrometração individual. No Quadro 14 estão listadas cidades e estados brasileiros que têm legislação onde há obrigatoriedade de individualização dos hidrômetros. Na maioria dos casos, o foco principal é nas edificações residenciais. No caso dos edifícios públicos, destacam-se o Estado de Pernambuco e sua capital Recife, cuja abrangência da lei atinge todo tipo de edificação.

Há também legislações apenas permissivas, que não impõem a regra como obrigação. Um exemplo é a Lei $\mathrm{n}^{\circ} 17.506$ (2008) que trata da medição individualizada no estado de Minas Gerais. Ao contrário das demais leis que têm surgido nos municípios e estados brasileiros no decorrer dos últimos anos, essa Lei não obriga a instalação de medição individualizada, mas apenas sugere que tal instalação seja considerada na planta hidráulica das novas edificações.

Da mesma forma ocorre no Distrito Federal, onde a Lei $\mathrm{n}^{\circ} 4.383$ (2009) ajustou lei anterior que obrigava a instalação de hidrômetros, para passar a ser optativa sua instalação, bastando 
para tanto enviar para a concessionária local uma justificativa para a inviabilidade técnica dessa instalação.

Quadro 14 - Exemplos de legislação municipal e estadual com obrigatoriedade de hidrometração individual em edifícios

\begin{tabular}{|c|c|c|}
\hline Localização & Lei / Norma & Abrangência \\
\hline Passo Fundo/RS & $\begin{array}{c}\text { Lei } \\
\text { Complementar } \\
110 / 2003\end{array}$ & Residenciais multifamiliares e comerciais. \\
\hline Curitiba/PR & $\begin{array}{c}\text { Lei Municipal } \\
10.785 / 2003\end{array}$ & Condomínios. \\
\hline Recife/PE & $\begin{array}{c}\text { Lei Municipal } \\
16.759 / 2002\end{array}$ & $\begin{array}{l}\text { Todos os edifícios, independentemente da categoria de usuários a que } \\
\text { pertençam (residenciais, comerciais, públicos, mistos) e da área das } \\
\text { unidades. }\end{array}$ \\
\hline Ribeirão Preto/SP & $\begin{array}{l}\text { Lei Municipal } \\
10.489 / 2005\end{array}$ & $\begin{array}{l}\text { Imóveis construídos em novos condomínios verticais ou horizontais, } \\
\text { como requisito de aprovação do projeto junto à prefeitura. }\end{array}$ \\
\hline Itabira/MG & $\begin{array}{l}\text { Lei Municipal } \\
4.524 / 2012\end{array}$ & $\begin{array}{l}\text { Novas edificações e projetos de três andares ou mais, como prédios de } \\
\text { apartamentos, prédios comerciais, condomínios horizontais, conjuntos } \\
\text { habitacionais e outros imóveis que constituam pluralidade de unidades } \\
\text { de consumo, condicionado à aprovação de projeto detalhado na } \\
\text { prefeitura. }\end{array}$ \\
\hline Florianópolis/SC & $\begin{array}{l}\text { Lei } \\
\text { Complementar } \\
171 / 2005\end{array}$ & Edificações residenciais multifamiliares. \\
\hline Niterói/RJ & $\begin{array}{c}\text { Lei Municipal } \\
2.340 / 2006\end{array}$ & $\begin{array}{l}\text { Na aprovação de projetos de construção de edificações de uso coletivo, } \\
\text { sejam condomínios horizontais ou verticais, de uso residencial, } \\
\text { comercial ou misto. }\end{array}$ \\
\hline Vitória/ES & $\begin{array}{c}\text { Lei Municipal } \\
8.354 / 2012\end{array}$ & $\begin{array}{l}\text { Prédios de apartamentos. Se houver aquecimento de água por meio de } \\
\text { energia solar, esta água deverá ser rateada proporcionalmente ao } \\
\text { consumo de cada unidade. }\end{array}$ \\
\hline Blumenau/SC & $\begin{array}{l}\text { Lei } \\
\text { Complementar } \\
902 / 2013\end{array}$ & $\begin{array}{l}\text { Qualquer projeto de construção e/ou reforma de instalações hidráulicas } \\
\text { de edifícios multifamiliares dos condomínios residenciais, do Programa } \\
\text { Minha Casa Minha Vida ou dos programas habitacionais } \\
\text { implementados em parceria com o governo estadual ou federal. }\end{array}$ \\
\hline Salvador/BA & $\begin{array}{c}\text { Lei Municipal } \\
7.780 / 2009\end{array}$ & $\begin{array}{l}\text { Prédios de apartamentos, condomínios horizontais, conjuntos } \\
\text { habitacionais e loteamentos. Há brecha para não execução, desde que } \\
\text { comprovada a inviabilidade técnica. }\end{array}$ \\
\hline Piracicaba/SP & $\begin{array}{l}\text { Lei } \\
\text { Complementar } \\
169 / 2004\end{array}$ & Condomínios horizontais e verticais. \\
\hline Campinas/SP & $\begin{array}{l}\text { Lei } \\
\text { Complementar } \\
13 / 2006\end{array}$ & Unidades autônomas dos condomínios em geral. \\
\hline $\begin{array}{c}\text { Estado de } \\
\text { Pernambuco }\end{array}$ & $\begin{array}{l}\text { Lei Estadual } \\
12.609 / 2004\end{array}$ & $\begin{array}{l}\text { Edifícios e condomínios com mais de uma unidade de consumo, } \\
\text { independente da categoria de usuários a que pertença, residenciais, } \\
\text { comerciais, públicos, mistos; e da área das unidades. }\end{array}$ \\
\hline
\end{tabular}

Fontes: Passo Fundo (2003); Curitiba (2003); Recife (2002); Ribeirão Preto (2005); Itabira (2012); Florianópolis (2005); Niterói (2006); Vitória (2012); Blumenau (2013); Salvador (2009); Piracicaba (2004); Campinas (2006) e Estado de Pernambuco (2004).

Atualmente tramita na Câmara dos Deputados o PL 5020/2013, oriundo do Senado, cujo objetivo é determinar que, nos condomínios edilícios, a hidrometração unitária seja obrigatória em todo o Brasil. Propõe-se que a modificação legal entre em vigor depois de decorridos cinco anos de sua publicação. 
De acordo com a norma brasileira NBR 8009 (1997), o hidrômetro é um aparelho destinado a indicar e totalizar, continuamente, o volume de água que o atravessa. No Brasil, apesar de os preços ainda não serem atrativos para a hidrometração unitária, há empresas especializadas nesse tipo de serviço, exemplificado na Foto 2. Nesse sistema de medição individual de consumo de água, cada usuário paga o que usa, como já ocorre com sistemas de medição de consumo de energia elétrica, telefone e gás.

Foto 2 - Exemplo de hidrometração unitária instalada

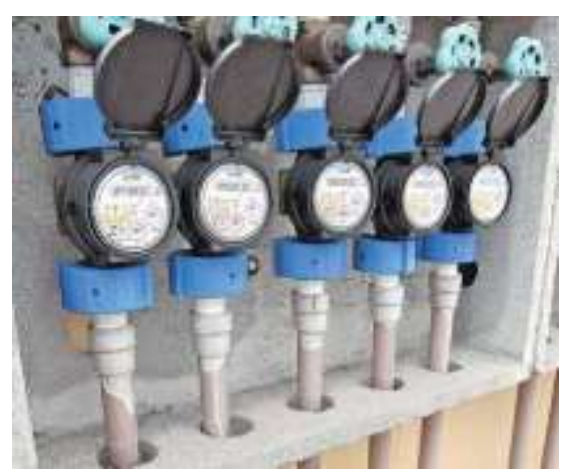

Fonte: aquafluxus.com.br

Os medidores, de acordo com indicação dos fornecedores, devem ser instalados nas áreas comuns (fora dos apartamentos), em local de fácil acesso, leitura e manutenção, pois os hidrômetros, mesmo que utilizando sistemas de telemetria para a leitura, estão passíveis de fraude quando são instalados dentro dos apartamentos, dado que não há como garantir a lisura da leitura.

Conforme se pode observar na Figura 7, a distribuição pode se dar em cada pavimento, no barrilete ou no nível de entrada do edifício. Essa recomendação na instalação tem seu entendimento normatizado em algumas concessionárias de água e esgoto de todo o Brasil, como, por exemplo, a Sabesp, por meio das NTS 277 e 279.

A partir da instalação dos medidores nas áreas comuns externas aos apartamentos, temos dois tipos de sistema de leitura que podem ser adotados:

- Leitura visual, necessitando mensalmente de profissional para coletar as informações de consumo dos medidores;

- Leitura remota, na qual as informações são passadas por sistema eletrônico via radiofrequência ou via internet. 
As empresas que executam esse tipo de serviço devem seguir a norma NBR 15806 (2010). Com o sistema implantado no condomínio, a detecção de vazamentos fica muito mais fácil, já que a empresa responsável pelo serviço monitora o consumo de água todo o tempo.

Figura 7 - Tipos de distribuição de medição individualizada em um edifício

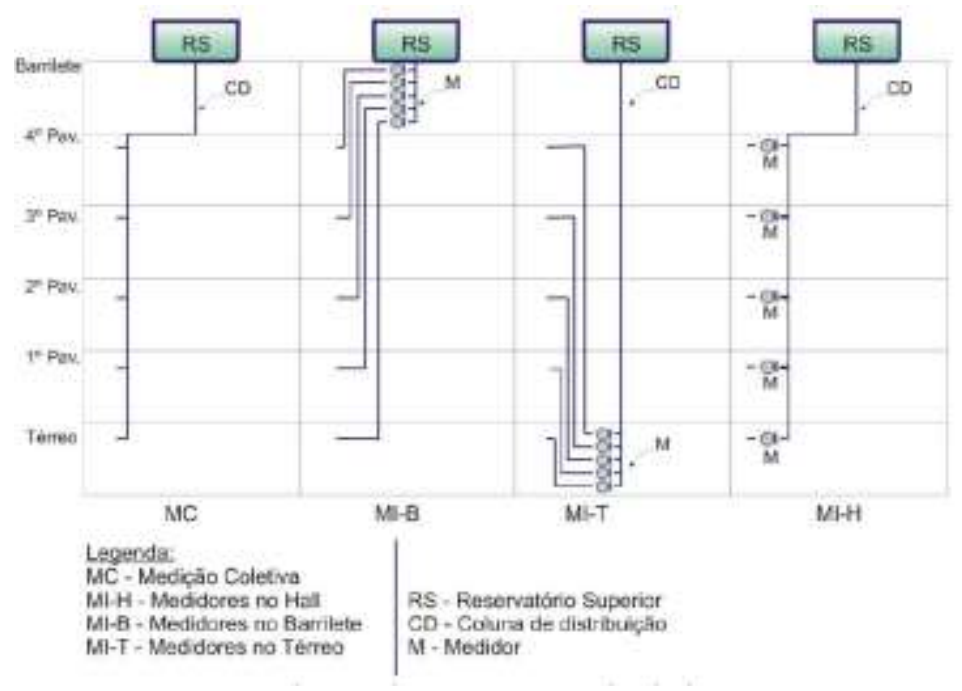

Fonte: aquafluxus.com.br

Para garantir a qualidade do processo de individualização do consumo de água, a Companhia de Saneamento Básico do Estado de São Paulo (Sabesp) criou em 2009 o ProAcqua (Programa de Qualidade e Produtividade dos Sistemas de Medição Individualizada de Água). O ProAcqua, pioneiro no Brasil, oferece a possibilidade de as contas individuais serem enviadas pela empresa, não sendo mais necessária qualquer administração do condomínio.

Considerando a coleta das melhores informações possíveis, qualitativa e quantitativamente, essencial num contexto de conservação de água, Tamaki (2003) também recomenda a aplicação de sistemas de telemedição na individualização dos hidrômetros.

A leitura remota ou telemedição é a tecnologia da automatização da medição e da transmissão de dados de fontes remotas para estações de recebimento, comumente usada em locais de difícil acesso para a leitura visual, onde os dados sofrem processamento e análise, como exemplificado na Figura 8.

Os primeiros sistemas baseavam-se em leitores móveis portáteis com os quais os leituristas, em percursos a pé, estabeleciam uma comunicação com cada medidor e registravam as leituras no próprio equipamento. Atualmente, com a evolução do próprio sistema, ampliou-se a capacidade de realizar leituras a partir da utilização de coletores instalados em veículos ou 
fixos em postes e antenas. Após a coleta dos dados, um servidor gerencia e aplica as informações.

Figura 8 - Exemplo de coleta de dados remota de hidrômetros

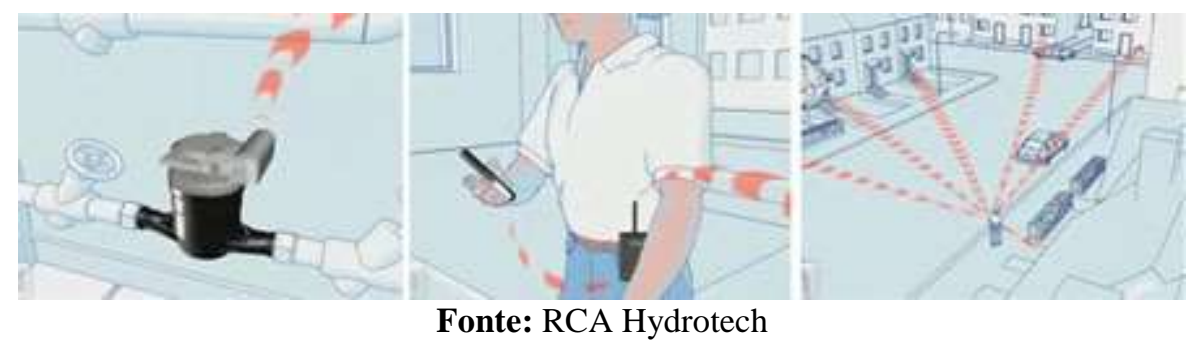

Além de informar os dados do consumo, o sistema de telemedição também transmite diversos alarmes, por exemplo, se existem sinais de vazamentos ou sinais de tentativas de fraude.

\subsection{Equipamentos economizadores de água (EEAs)}

Os equipamentos economizadores de água (EEAs) apresentam características específicas de instalação, funcionamento, operação e manutenção. A adoção desses componentes hidráulicos pelo Brasil vem crescendo de forma acelerada em prédios de uso público, principalmente porque o seu emprego associa esses espaços à sustentabilidade das construções, proporcionando redução das despesas na conta de água e esgoto, e, eventualmente, redução na conta de energia elétrica.

De acordo com o CBCS (2010), para garantir um bom desempenho, é necessário o conhecimento de algumas especificações, tais como: os usos particulares de cada peça; o tipo de usuário mais adequado para sua utilização; orientações dos fabricantes e capacitação dos usuários para instalação e operação adequadas dos produtos; e recomendações dos fabricantes para manutenção preventiva e corretiva adequada ao equipamento, que deve ser realizada periodicamente.

Segundo Hafner (2007), o emprego de dispositivos é um importante meio de reduzir o consumo de água e costuma ter grande aceitação devido à fácil visualização do funcionamento e à confiabilidade nesses produtos pelo público geral. Essa solução de economia de água independe da colaboração contínua do usuário, o que os torna especialmente recomendados para instalações sanitárias públicas.

Conforme aponta Marinoski e Andrade (2010), os componentes economizadores podem ser adotados facilmente em fase de projeto. Já em edificações existentes e ocupadas, a substituição de equipamentos convencionais por componentes economizadores de água pode 
apresentar dificuldades técnicas e ser mais onerosa. Assim, deve-se observar a viabilidade técnica e econômica da substituição desses equipamentos, de acordo com o consumo verificado em estudos de usos finais de água.

O potencial de redução do consumo total de água proporcionado pela substituição de equipamentos convencionais por componentes economizadores, de acordo com os mesmos autores, pode variar em função das condições locais (pressão do ramal de alimentação) e também dos hábitos dos usuários (frequência e tempo de acionamento). Entretanto, a economia de água oferecida pela instalação desses componentes economizadores pode ser mais significativa quando aliada a um trabalho de conscientização.

O MMA (2014) acrescenta que os componentes hidráulicos devem ser adequados aos usos específicos de cada ponto de consumo. Assim, não necessariamente deve-se utilizar um equipamento economizador, mas sim o equipamento que proporcione maior conforto e desempenho do consumo de água em cada ponto de consumo. Por exemplo, utilizar uma torneira hidromecânica em uma pia de cozinha industrial, que é um equipamento economizador, dificultaria o seu uso, podendo, inclusive, aumentar o desperdício de água. Todavia, uma torneira com abertura e fechamento por alavanca, mesmo sendo um equipamento convencional, seria mais adequada. Neste caso, poderia ser instalado nessa torneira um acessório economizador como um arejador.

A especificação de louças, metais sanitários e equipamentos hidráulicos é um dos fatores que determinam o maior ou menor consumo de água em uma edificação, ao longo de sua vida útil. Existe atualmente no mercado brasileiro uma grande variedade de equipamentos sanitários que têm como objetivo promover o uso racional da água para as atividades a que se destinam. Preferencialmente, devem ser especificados equipamentos cujos componentes apresentem maior durabilidade para viabilizar os custos provenientes de manutenção. No Quadro 15 estão listados os EEAs mais utilizados no mercado brasileiro, bem como suas características principais.

Para o uso em edifícios públicos, foi verificada no mercado brasileiro a disponibilidade de equipamentos ainda pouco difundidos e especificados, especialmente pela necessidade de ajuste de hábitos dos usuários, da cultura do uso, conforme se observa no Quadro 16. Para consolidar essa adaptação, faz-se necessária uma ampla divulgação das mudanças com antecedência, incluindo informações claras acerca dos benefícios em relação à economia de água e a redução do impacto ambiental decorrente. 
Quadro 15 - Equipamentos economizadores de água

\begin{tabular}{|c|c|c|}
\hline $\begin{array}{l}\text { Equipamentos } \\
\text { hidráulicos }\end{array}$ & Tipo & Características principais \\
\hline \multirow{3}{*}{ Torneiras } & $\begin{array}{l}\text { Acionamento } \\
\text { Hidromecânico }\end{array}$ & $\begin{array}{l}\text { O controle da vazão é obtido pela incorporação de um redutor de } \\
\text { vazão no equipamento, ou seja, os usuários não interferem na vazão. } \\
\text { O tempo de acionamento do fluxo de água também determina o uso } \\
\text { racional deste tipo de equipamento. Este tempo não deve ser muito } \\
\text { curto, para evitar que o usuário tenha que acioná-lo várias vezes em } \\
\text { uma única operação de lavagem, causando desconforto. Segundo os } \\
\text { fabricantes, esse tempo pode variar de } 4 \text { a } 10 \text { segundos. }\end{array}$ \\
\hline & $\begin{array}{l}\text { Acionamento por } \\
\text { sensor de } \\
\text { presença }\end{array}$ & $\begin{array}{l}\text { Equipamento que funciona a pilha ou a bateria, com acionamento da } \\
\text { torneira enquanto há movimento à frente do sensor. O desligamento é } \\
\text { automático e ocorre cerca de } 2 \text { segundos após o uso. Os equipamentos } \\
\text { mais modernos dispõem ainda de um dispositivo hidrogerador, que } \\
\text { dispensa o uso de baterias ou pilhas. Tal solução utiliza a própria } \\
\text { força da água para armazenar energia para o acionamento. }\end{array}$ \\
\hline & Sensível ao toque & $\begin{array}{l}\text { Libera e interrompe o fluxo de água somente ao ser tocada pelo corpo } \\
\text { humano. Segundo o fabricante, pode-se limpar a peça com um pano } \\
\text { ou encostar qualquer objeto que a torneira não funcionará. Ela } \\
\text { também possui sistema de regulagem do tempo de abertura da torneira } \\
\text { durante } 4,8,30 \text { ou } 60 \text { segundos, caso o usuário esqueça de tocar a } \\
\text { torneira pela segunda vez. }\end{array}$ \\
\hline Arejad & \multicolumn{2}{|c|}{$\begin{array}{l}\text { Dispositivo regulador e redutor do fluxo de saída de água, usualmente montado na } \\
\text { extremidade de torneiras e bicas em geral, destinado a promover o direcionamento do } \\
\text { escoamento de água, evitando dispersões laterais e amortecendo o impacto do jato de água } \\
\text { contra as partes que estão sendo lavadas. É também um componente que propicia a redução } \\
\text { de consumo de água sem comprometimento das operações de lavagem em geral. Os } \\
\text { arejadores funcionam pelo princípio de Venturi, incorporando considerável quantidade de } \\
\text { ar ao fluxo de água e reduzindo a vazão e o volume de água utilizado. A referência média } \\
\text { de vazão adotada é de } 8 \text { litros/minuto, podendo chegar a } 1,8 \text { litro/minuto. }\end{array}$} \\
\hline Pulverizadores & \multicolumn{2}{|c|}{$\begin{array}{l}\text { Dispositivo fixado na saída da torneira, porém não tem orifícios laterais para a introdução } \\
\text { de ar. Transforma o jato de água em um feixe de pequenos jatos, semelhante ao que ocorre } \\
\text { em um chuveiro. Reduz a vazão para valores entre } 3,6 \text { litros/minuto e } 7,2 \text { litros/minuto } \\
\text { sem reduzir a satisfação do usuário. }\end{array}$} \\
\hline \multirow{2}{*}{$\begin{array}{l}\text { Dispositivos de } \\
\text { descarga para } \\
\text { mictórios } \\
\text { convencionais }\end{array}$} & $\begin{array}{l}\text { Válvula de } \\
\text { acionamento } \\
\text { hidromecânico }\end{array}$ & $\begin{array}{l}\text { É caracterizada por um corpo metálico fechado, por onde a água passa } \\
\text { para chegar ao mictório. Para o acionamento da descarga após a } \\
\text { utilização do mictório, o usuário deve pressionar o êmbolo da válvula, } \\
\text { liberando o fluxo de água para a bacia do mictório. Imediatamente } \\
\text { após a liberação da pressão pelo usuário, ocorre o retorno do êmbolo } \\
\text { pela ação da própria água e de uma mola interior ao corpo da válvula, } \\
\text { podendo durar entre } 4 \text { e } 10 \text { segundos. }\end{array}$ \\
\hline & $\begin{array}{l}\text { Válvula acionada } \\
\text { por sensor de } \\
\text { presença }\end{array}$ & $\begin{array}{l}\text { Dispositivo passível de regulagem, que funciona sem o controle do } \\
\text { usuário, acionando automaticamente o fluxo de água para limpeza do } \\
\text { mictório no momento do distanciamento do corpo do usuário após o } \\
\text { uso. }\end{array}$ \\
\hline \multirow[t]{2}{*}{ Chuveiros } & Restritor de vazão & $\begin{array}{l}\text { Mantém a vazão constante dentro de uma faixa de pressão. Existem } \\
\text { restritores com os mais diferentes desenhos, reduzindo, segundo o } \\
\text { fabricante pesquisado, de } 20 \% \text { a } 60 \% \text { da vazão, cuja referência média } \\
\text { é de } 20 \text { litros/minuto. Ressalta-se que é recomendada uma pressão } \\
\text { hidráulica mínima de } 10 \text { mca. }\end{array}$ \\
\hline & $\begin{array}{l}\text { Reguladores de } \\
\text { vazão }\end{array}$ & $\begin{array}{l}\text { Dispositivo recomendável para quem tem costume de abrir o registro } \\
\text { no máximo, mesmo sem necessidade. A peça é instalada entre a saída } \\
\text { de água na parede e a torneira. Também podem ser utilizados nos }\end{array}$ \\
\hline
\end{tabular}




\begin{tabular}{|c|c|l|}
\hline $\begin{array}{c}\text { Equipamentos } \\
\text { hidráulicos }\end{array}$ & Tipo & \multicolumn{1}{c|}{ Características principais } \\
\hline \multirow{6}{*}{ Bacias sanitárias } & $\begin{array}{l}\text { chuveiros com aquecimento central. Segundo o fabricante pesquisado, } \\
\text { a economia pode chegar a 60\%, considerando um chuveiro com vazão } \\
\text { média de 20 litros/minuto. }\end{array}$ \\
\cline { 2 - 3 } & $\begin{array}{c}\text { Com válvulas de } \\
\text { cescarga de duplo } \\
\text { comando } \\
\text { acoplada de duplo } \\
\text { comando }\end{array}$ & $\begin{array}{l}\text { No mercado, atualmente, a tecnologia dominante é a conhecida como } \\
\text { dual-flush, que possibilita dois tipos de acionamento da descarga de } \\
\text { água neste tipo de bacia sanitária, por meio da existência de dois } \\
\text { botões: um deles, quando acionado, resulta em uma descarga } \\
\text { completa de 6 litros, para o arraste de efluentes com sólidos, e o outro } \\
\text { resulta em uma meia descarga, geralmente de 3 litros, para a limpeza } \\
\text { apenas de urina na bacia sanitária. }\end{array}$ \\
\hline
\end{tabular}

Fontes: CBCS (2010) e Marinoski e Andrade (2010) - adaptado

Outra característica que se faz presente em alguns equipamentos e que tem reflexo indireto sobre o consumo de água é o antivandalismo. As soluções adotadas reduzem drasticamente a possibilidade de danos ou roubos nestas peças e são recomendadas especificamente para uso público. Essa não é a realidade comum em repartições públicas administrativas, mas pode ser adotada para prevenção de sinistros.

Quadro 16 - Equipamentos economizadores de baixa utilização em edifícios públicos

\begin{tabular}{|c|c|}
\hline Equipamento & Função \\
\hline $\begin{array}{c}\text { Torneiras para mictório com } \\
\text { lavatório }\end{array}$ & $\begin{array}{l}\text { Equipamento disponível com acionamento hidromecânico ou com sensor } \\
\text { de presença, sistema antivandalismo e restritores de vazão constante } \\
\text { embutidos, variando de } 6 \text { a } 8 \text { litros/minuto. O equipamento é instalado } \\
\text { acima do mictório, que incorpora um lavatório de profundidade reduzida, } \\
\text { para evitar o desconforto. A água para lavagem das mãos é reutilizada } \\
\text { para a limpeza do mictório. }\end{array}$ \\
\hline $\begin{array}{l}\text { Válvula para chuveiro com } \\
\text { fechamento automático }\end{array}$ & $\begin{array}{l}\text { Pensada para diminuir o desperdício de água. Seu acionamento é } \\
\text { automático temporizado, liberando apenas a quantidade necessária para } \\
\text { cada uso. Segundo o fabricante pesquisado, garante a economia de até } \\
60 \% \text { de água, considerando uma vazão média de } 20 \text { litros/minuto. O } \\
\text { tempo de fechamento de cada ciclo varia, segundo o fabricante } \\
\text { pesquisado, de } 18 \text { a } 50 \text { segundos. }\end{array}$ \\
\hline Mictório se & $\begin{array}{l}\text { Diante da crise hídrica de } 2014 / 2015 \text {, essa solução foi rapidamente } \\
\text { inserida no mercado de construção civil. Trata-se de um mictório que } \\
\text { dispensa completamente o uso de água em sua limpeza. Para evitar o mau } \\
\text { cheiro após o uso, foi utilizado um fecho mecânico de silicone, que evita } \\
\text { o refluxo de gases provenientes da proliferação de bactérias presentes na } \\
\text { urina humana. Para limpeza, o fabricante pesquisado recomenda o uso de } \\
\text { papel toalha com detergente neutro na superfície da peça, duas vezes ao } \\
\text { dia. }\end{array}$ \\
\hline
\end{tabular}

Fonte: Deca (2015) 
Outro fator importante a ser considerado é a especificação de equipamentos adequados ao uso a que se destinam. De acordo com a ANA (2005), a adequada especificação de equipamentos requer o entendimento do funcionamento do aparelho, das atividades envolvidas e do tipo de usuário para identificação dos requisitos de desempenho a serem atendidos.

\subsection{Aproveitamento de águas pluviais (AAP)}

A água de chuva é uma das formas de ocorrência de água na natureza e faz parte do processo de trocas do ciclo hidrológico. As chuvas são fundamentais para a recarga dos rios, dos aquíferos, para o desenvolvimento das espécies vegetais e também para carregar partículas de poeira e poluição existentes na atmosfera. A qualidade das águas pluviais pode variar em relação ao grau de poluição do ambiente. Os requisitos de qualidade e segurança sanitária das águas pluviais estão diretamente relacionados com o fim a que se destinam.

Destacam-se algumas recomendações de suma importância na implantação de sistemas de aproveitamento da água de chuva nas edificações:

- A desinfecção da água de chuva armazenada antecipadamente ao uso;

- A higienização frequente do reservatório de água de chuva;

- A análise da concepção do método de dimensionamento, a fim de subsidiar a escolha mais adequada a cada situação;

- A construção de sistemas independentes para água de chuva e água potável a fim de evitar o risco de contaminação.

ANA et al. (2005) salienta que os principais parâmetros a serem considerados no projeto de um sistema de aproveitamento de água de chuva são o(a):

- Demanda de água de chuva;

- Demanda de água potável;

- Qualidade requerida para o uso pretendido;

- Regime pluviométrico local, indicando o índice médio de precipitação pluviométrica e sua distribuição no tempo e no espaço;

- Período de estiagem, com foco no número máximo de dias consecutivos sem chuva, considerando um período mínimo de segurança aceitável para cada situação, ou seja, para um período de retorno satisfatório;

- Área de captação necessária, disponível ou, ainda, possível de ser utilizada e de acordo com a qualidade de água requerida; 
- Coeficiente de aproveitamento de água de chuva.

Os principais motivos que levam à decisão para se utilizar água de chuva em edifícios, conforme Tomaz (2009), são, entre outros, os seguintes:

- Conscientização e sensibilidade da necessidade da conservação da água;

- Região com disponibilidade hídrica menor que 1.200 m³/habitante/ano;

- Elevadas tarifas de água das concessionárias públicas;

- Retorno dos investimentos (payback) muito rápido;

- Instabilidade do fornecimento de água pública;

- Locais onde ocorrem períodos de estiagem maiores que cinco meses.

A Figura 9 mostra um esquema básico de sistema AAP. A água proveniente desses sistemas é utilizada, na maioria das vezes, para a irrigação de jardins, caixas acopladas de vasos sanitários e lavagem de veículos e pisos. Esse uso gera economia de água potável e de custos aos usuários, bem como redução do gasto de energia. No caso de estabelecimentos públicos, segundo Alves (2010), o uso de AAPs pode ser mais abrangente, utilizando-se a água em centrais de água gelada de sistemas de ar condicionado, sistemas de combate a incêndios e reposição de água evaporada de espelhos d'água.

Figura 9 - Esquema básico de sistema AAP

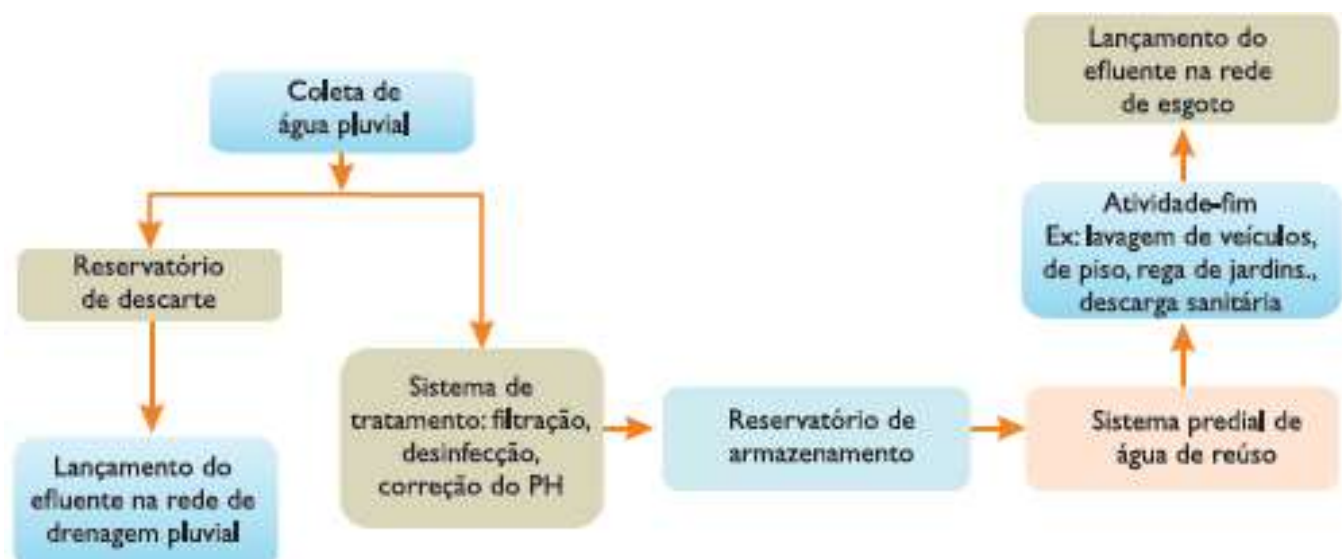

Fonte: MMA (2014)

As desvantagens do uso de AAPs estão associadas especialmente à variabilidade temporal da precipitação, pois o suprimento é limitado, uma vez que depende da quantidade de chuva e da área do telhado, bem como à qualidade da água, pois se a utilização for para consumo humano e a água não for devidamente tratada, poderá pôr em risco a saúde dos usuários. Por uma pesquisa expedita dos fornecedores de sistemas AAP no Brasil, percebe-se que não há 
indicação à ingestão humana, mas tão somente ao uso em vasos sanitários, mictórios, sistemas de irrigação e lavagem de pisos.

Cabe ressaltar ainda que, ao reservar e utilizar águas pluviais, além de reduzir o consumo de água potável para diversos fins, a edificação em questão contribuirá para a prevenção de enchentes. Em se tratando de sistemas de aproveitamento da água de chuva, como o esquema exemplificado na Figura 10, a manutenção e higienização dos equipamentos componentes de tal sistema são fundamentais para a preservação da qualidade da água.

Figura 10 - Corte esquemático do reservatório do sistema AAP

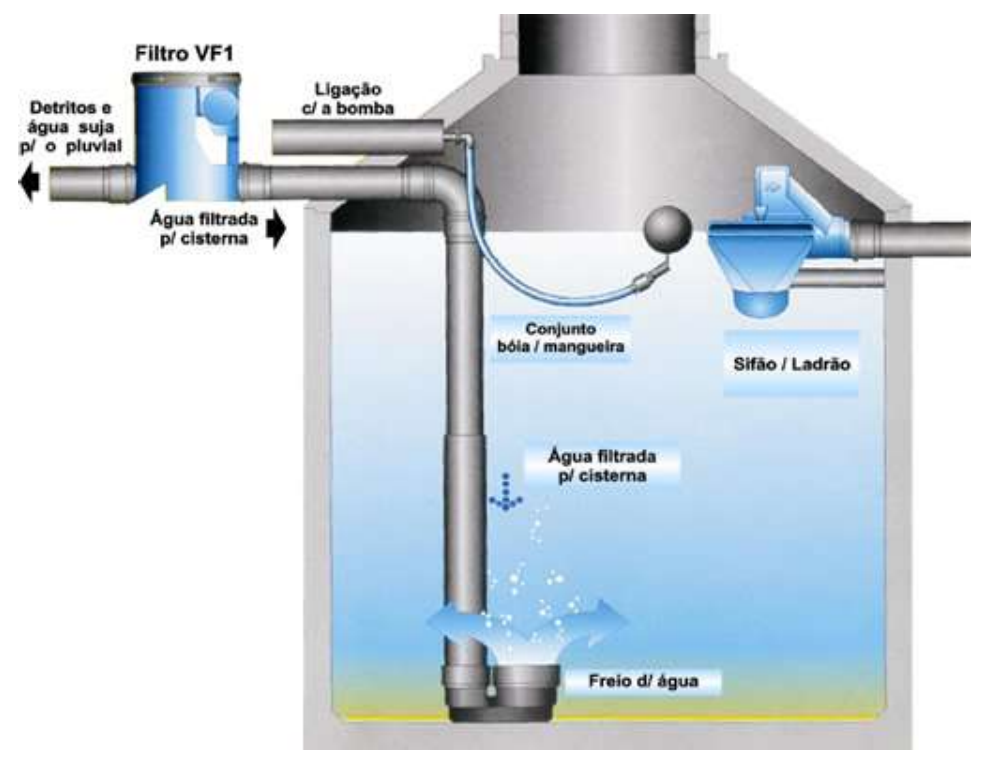

Fonte: 3P Technik

Segundo Giacchini (2011), a superfície de coleta da água de chuva pode influenciar na sua qualidade, seja pelo material desta superfície ou devido a substâncias presentes nela, como, por exemplo: fezes de aves e roedores, artrópodes e outros animais mortos em decomposição, poeira, folhas e galhos de árvores, revestimento do telhado, fibras de amianto e resíduos de tintas.

No caso dos edifícios públicos, parte-se do pressuposto que existam funcionários próprios ou terceirizados da área de manutenção predial que realizam os serviços de limpeza dos telhados, dentro do escopo de manutenção preventiva.

Segundo o MMA (2014), os sistemas de aproveitamento de águas pluviais apresentam-se vantajosos quando a área de coleta disponível é superior a $250 \mathrm{~m}^{2}$. A partir dessa condição, pode-se dar andamento ao projeto, para a determinação da capacidade do reservatório de armazenamento. $\mathrm{O}$ volume desse reservatório dependerá da disponibilidade de água para 
suprir o abastecimento em ocasiões de baixa precipitação. A NBR 15527 (2007) sugere, em seu Anexo A, alguns métodos para o dimensionamento do reservatório. Entretanto, fica a critério do projetista a escolha do método que melhor se aplica a cada situação.

Devem ser considerados os aspectos hidrológicos locais, o atendimento ao consumo, os aspectos sanitários e também a sustentabilidade hídrica da bacia hidrográfica. Armazenar grandes volumes de água de chuva nas edificações, por longos períodos de tempo, pode comprometer a segurança sanitária da água armazenada e ainda interferir no processo do ciclo do uso da água na bacia hidrográfica.

Sugere-se, para o dimensionamento do reservatório, uma análise das séries históricas das precipitações locais ou regionais, sendo aconselhável, no mínimo, um período de dez anos de dados coletados. Recomenda-se que haja dois reservatórios, sendo um para água potável e outro para não potável, que será usado para o aproveitamento da água de chuva.

De acordo com Tomaz (2009), os reservatórios devem ser construídos como se fossem para armazenamento de água potável, devendo ser tomados os devidos cuidados para não contaminar a água de chuva coletada dos telhados. Eles podem ser enterrados, semienterrados, apoiados ou elevados, bem como feitos de concreto, alvenaria armada, polietileno, PVC, fibra de vidro (mais utilizados e comumente encontrados no mercado) e aço inox. Recomenda-se que sejam vedados a luz solar, para inibir o crescimento de algas, bem como arejados, para evitar o desenvolvimento de insetos. Este elemento é o mais caro de todo o sistema de aproveitamento de águas pluviais.

Os pontos de consumo (por exemplo, uma torneira de jardim) devem ser identificados com placa de advertência com a seguinte inscrição "água não potável” e advertência visual destinada a pessoas que não saibam ler e a crianças.

Passados mais de três dias de seca, é aconselhável que essa primeira água seja descartada por meio de um mecanismo denominado first flush. Segundo Tomaz (2009), o volume eliminado varia de 0,4 litro $/ \mathrm{m}^{2}$ a 8 litros $/ \mathrm{m}^{2}$ de telhado, conforme o local. Na falta de dados locais, sugere-se o uso do first flush no valor de 2 litros $/ \mathrm{m}^{2}$ de área de telhado.

Para desinfecção, a critério do projetista, pode-se utilizar hipoclorito de sódio, dicloroisocianurato de sódio, raios ultravioleta, ozônio e outros. Pode ser instalado junto à bomba centrífuga um dosador automático de derivado clorado, o qual convém ser enviado a um reservatório intermediário para que haja tempo de contato de, no mínimo, 15 minutos. 


\subsection{Uso de águas residuárias tratadas}

A água é um bem que tem se tornado cada vez mais escasso, seja pelo crescimento da população, pela própria poluição dos mananciais hídricos ou por qualquer outro fator condicionante. $\mathrm{O}$ uso de águas tratadas (ou reúso de águas servidas) é uma possibilidade para reversão do quadro de escassez, unindo comprometimento social e ambiental. O uso de fontes alternativas de água para fins menos nobres é importante para a preservação ambiental, porém cabe salientar a responsabilidade no manejo e na execução dos sistemas e os riscos associados a sua aplicação.

O termo reúso, utilizado pela maioria dos autores que tratam do tema de conservação de água, é entendido nesta pesquisa como a reutilização de águas servidas (proveniente de usos em máquinas de lavar roupas e tanques, especialmente) que não recebem qualquer tratamento posterior ao uso.

As águas tratadas, também classificadas como águas de reúso por alguns autores, são aquelas que, após seu uso e posterior tratamento, demandam uma utilização. Estas são comumente classificadas na literatura como águas cinzas e águas residuárias. A nomenclatura utilizada nesta pesquisa, portanto, será a de tratamento de águas cinzas (TACs) e de águas residuárias (TARs). Os sistemas AAP também recebem tratamento antes de seu uso, mas não têm utilização prévia, sendo, portanto, tratados em separado, como já foi feito no item 2.3.

Pelo fato de esta água tratada não possuir as mesmas características da água servida antes do tratamento, considerou-se inapropriado o termo "reúso" nestes casos, pois não se está reutilizando a mesma água, com as mesmas características físico-químicas da água resultante do primeiro uso. Cabe ressaltar que o termo "reúso" só será utilizado nos casos entendidos nesta pesquisa como tal e mantido em citações textuais.

Segundo o comitê temático da água do CBCS (2010), devem ser considerados alguns tópicos para o uso de fontes alternativas em projetos de usos de águas tratadas, como, por exemplo:

- Análise dos pontos de risco de contaminação no sistema de água potável;

- Análise dos parâmetros de qualidade de água para usos restritivos não potáveis, das legislações e das normalizações específicas de referência das regiões de aplicação;

- Cuidados relativos às conexões;

- Necessidade de reservas independentes;

- Especificação dos materiais que serão utilizados em tubulações, válvulas e conexões; 
- Capacitação do usuário final para minimização dos riscos;

- Projeto de sinalização para conscientização dos usuários.

De acordo com Dantas e Sales (2009), o uso de águas tratadas constitui método que reduz a produção de efluentes e o consumo de água de qualidade superior (água distribuída pelas concessionárias públicas ou retirada diretamente dos mananciais hídricos), com a substituição da água potável por água que já fora previamente usada. Pode ser compreendido como alternativa recomendável para satisfazer a demanda menos exigente, liberando as águas de melhor qualidade para uso mais nobre, como para consumo humano e higiene pessoal. Cabe ressaltar que tratamento em nível urbano não será aprofundado neste trabalho, mas tão somente em edificações.

Gonçalves (2009) apresenta um modelo de gerenciamento com linhas diferenciadas para o suprimento de água potável e não potável. Destacam-se, dentre as linhas de produção de águas residuárias domésticas para fins não potáveis:

- Águas negras: águas residuárias procedentes das bacias sanitárias, as quais apresentam em seu conteúdo fezes, urina e papel higiênico;

- Águas amarelas: águas residuárias oriundas dos dispositivos separadores de urina e fezes, como os mictórios e as bacias sanitárias de duplo comando;

- Águas cinzas: águas servidas, oriundas de pontos de consumo como os lavatórios, chuveiros, banheiras, pias de cozinha, máquinas de lavar roupas e tanques.

De acordo com o nível de tratamento e seu tipo de utilização, conforme descrito no Quadro 17, os sistemas de uso de águas tratadas podem ser classificados como uso potável (direto ou indireto) e uso não potável.

O uso potável direto ocorre quando, por meio de tratamento avançado, o esgoto tratado é reutilizado no sistema de água potável. O uso potável indireto é realizado quando o esgoto, após tratamento, é inserido em águas superficiais ou subterrâneas para diluição e purificação natural e posteriormente captada, tratada e disposta para uso potável. Já o uso não potável pode ser utilizado, de acordo com a qualidade de uso exigida, em diversos fins não potáveis: agrícolas, industriais, recreacionais e domésticos, como em rega de jardins, descargas sanitárias e lavagem de pisos (MANCUSO e SANTOS, 2003). 
Quadro 17 - Formas de uso de águas tratadas e suas características

\begin{tabular}{|c|l|}
\hline Formas de uso & \multicolumn{1}{c|}{ Características } \\
\hline Direto & $\begin{array}{l}\text { Uso planejado de esgotos tratados para certa finalidade como uso industrial, irrigação } \\
\text { e água potável. }\end{array}$ \\
\hline Indireto & $\begin{array}{l}\text { Quando a água, já utilizada, uma ou mais vezes para o uso doméstico ou industrial, é } \\
\text { descartada nas águas superficiais ou subterrâneas e utilizada novamente, mas de forma } \\
\text { diluída. }\end{array}$ \\
\hline \hline Planejado & $\begin{array}{l}\text { Quando este é resultado de uma ação planejada e consciente, adiante do ponto de } \\
\text { descarga do efluente a ser usado. }\end{array}$ \\
\hline Não planejado & Caracterizado pela maneira não intencional e não controlada de sua utilização. \\
\hline \hline Potável & Com a finalidade de abastecimento da população. \\
\hline Não potável & $\begin{array}{l}\text { Objetiva atender a demanda que tolera águas de qualidade inferior (fins industriais, } \\
\text { recreacionais, irrigação, descarga em vasos sanitários, entre outros). }\end{array}$ \\
\hline \hline Potável direto & $\begin{array}{l}\text { O esgoto é recuperado através de tratamento avançado e é injetado diretamente no } \\
\text { sistema de água potável. }\end{array}$ \\
\hline Potável indireto & $\begin{array}{l}\text { O esgoto depois de tratado é lançado nas águas superficiais ou subterrâneas para } \\
\text { diluição e purificação natural, objetivando uma posterior captação e tratamento. }\end{array}$ \\
\hline
\end{tabular}

Fonte: Adaptado de Mancuso e Santos (2003)

\subsubsection{Tratamento de águas cinzas}

A utilização da água cinza como fonte de água não potável vem crescendo cada vez mais no mundo inteiro. Os principais critérios que direcionam um programa de uso de tratamentos de águas cinzas (TACs) no Brasil, segundo ANA et al. (2005), são a preservação da saúde dos usuários e do meio ambiente, o atendimento às exigências relacionadas às atividades a que se destina e a quantidade suficiente ao uso a que será submetida.

De acordo com May (2009), alguns autores [Otterpohl (2001) e Eriksson et al. (2002), p. ex.] classificam as águas cinzas como águas servidas oriundas de tanques, banheiras, chuveiros, pias de cozinha, lavatórios, tanques e máquinas de lavar roupas. Outros autores [Allen et al. (2010) e Birks et al. (2007), p. ex.] descartam a água da cozinha, por conter óleos e gorduras, cujo processo de tratamento é bem mais complexo. O Quadro 18 apresenta o código de cores dos efluentes baseada em Henze e Ledin (2001).

Quadro 18 - Código de cores dos efluentes de um sistema de esgotamento sanitário

\begin{tabular}{|c|c|}
\hline Tipo & Contaminante \\
\hline Preto (blackwater) & Todos os efluentes domésticos misturados \\
\hline Cinza escuro & Banho, cozinha e lavatório \\
\hline Cinza claro (greywater) & Banho, lavatório e máquina de lavar roupas \\
\hline Amarelo & Somente a urina (mictório) \\
\hline Marrom & Somente as fezes (sem a urina) \\
\hline
\end{tabular}

Fonte: Henze e Ledin (2001)

Os elementos presentes nas TACs variam de acordo com os pontos de contribuição escolhidos, dependentes das diversas atividades associadas, variando de um edifício para outro, onde os costumes, instalações e a quantidade de produtos químicos utilizados 
influenciam nessa qualidade. Assim, é possível segregar os efluentes de um conjunto de aparelhos sanitários, de acordo com as características físico-químicas e biológicas de seus efluentes em função dos usos pretendidos.

Marinoski e Andrade (2010) apontam que os sistemas de utilização de águas cinzas geralmente envolvem tratamento biológico dos efluentes, que são posteriormente armazenados em um reservatório com volume adequado, dimensionado com base nas características ocupacionais da edificação, na contribuição de efluentes gerados e na demanda de água a ser utilizada. As instalações hidráulicas de um sistema de uso de águas tratadas devem ser absolutamente separadas das instalações hidráulicas de água potável, sendo proibida a conexão cruzada entre elas.

Alves (2010) afirma que a possibilidade de reutilizar a água apresenta várias vantagens, posto que:

- Há redução do consumo de água potável, promovendo, além dos benefícios ambientais, benefícios econômicos;

- É uma fonte quase permanente de água, pelo fato de a sua produção ser constante sempre que a edificação está ocupada;

- Há redução da dependência de água potável, sendo benéfico para locais com problemas de escassez de água.

As desvantagens se resumem essencialmente a questões sanitárias e econômicas, pois o tratamento da água e o custo associado a elas geralmente são elevados.

Hespanhol e May (2008) recomendam que as seguintes características sejam verificadas: a) não deve apresentar odores desagradáveis; b) não deve ser turva; c) não deve conter componentes que agridam as plantas ou que estimulem o crescimento de pragas; d) não deve ser abrasiva; e) não deve manchar superfícies; f) não deve apresentar risco de infecções ou contaminação por vírus ou bactérias prejudiciais à saúde humana; e f) não deve deteriorar os metais sanitários e máquinas.

De acordo com os mesmos autores, o uso de TACs deve-se restringir somente ao consumo não potável devido aos seguintes fatores:

- Risco elevado para a saúde dos usuários;

- Falta de normas técnicas adequadas;

- Falta de apoio e de fiscalização pelas instituições governamentais; 
- Falta de preparo, de controle e de manutenção do processo de tratamento de água para fins potáveis, pelo usuário não especializado; e

- Custo elevado do tratamento para fins potáveis, o que tornaria o sistema inviável.

A definição do tipo de tratamento para a água cinza deve considerar principalmente a grande variação de vazão em períodos curtos de tempo e a elevada biodegradabilidade. Os processos utilizados para tratar água cinza são semelhantes aos utilizados em estações de tratamento de esgoto sanitário (GIACCHINI, 2011).

Eriksson et al. (2002) acrescenta que, quando utilizada na lavagem das mãos ou em banhos, deve-se tomar cuidado com a estocagem e o transporte, pois pode haver crescimento de microrganismos patogênicos, gerando novos compostos orgânicos e inorgânicos e, consequentemente, maus odores. Isso reforça a necessidade de soluções de desinfecção e estocagem eficientes. De acordo com Viggiano (2010), quando utilizadas na lavagem de automóveis, as águas cinzas devem ser tratadas por um processo que, além da filtragem, promova a retirada dos produtos saponáceos agregados e óleo e proceda também a uma desinfecção final.

Não se deve dispensar o fato de que a água cinza é passível de conter contaminações das mais diversas, pela grande flexibilidade de uso dos aparelhos sanitários. Segundo a ANA et al. (2005), é comum ocorrer situações de usuários que fazem a higienização no banho, após a utilização da bacia sanitária, ou a lavagem de ferimentos em qualquer torneira disponível, seja de um tanque ou lavatório, ou ainda a presença de urina na água de banho.

As principais dificuldades para a implantação de sistemas de TACs no Brasil são a carência de normas técnicas para uso não potável, a falta de conscientização da população para a necessidade de preservação dos recursos hídricos e energéticos, a falta de incentivo do governo e dos órgãos competentes e a falta de esclarecimento e ensino da população sobre o assunto (MAY, 2009).

\subsubsection{Tratamento de águas residuárias}

Os tratamentos de águas residuárias (TARs) são processos artificiais de depuração, remoção de poluentes e adequação a indicadores que tornam o efluente próprio para utilização em sistemas que necessitam de água ou para lançamento e disposição final nos corpos d'água receptores. Segundo a ONU (2015), as águas residuárias devem ser valorizadas em todas as 
suas formas e sempre tratadas como recursos em que se aproveitam energia, nutrientes e, ao fim do ciclo de tratamento, a água potável para reutilização.

Os processos de TARs, conforme Nunes (2010), são classificados em três tipos: físicos, químicos e biológicos. Os primeiros são processos em que se aplicam fenômenos de natureza física, como, por exemplo: gradeamento, peneiramento, sedimentação, floculação, decantação, filtração, osmose reversa e resfriamento. No segundo caso, ocorre aplicação de produtos químicos ou de reações e interações químicas, tais como: coagulação, correção de pH (neutralização), equalização (homogeneização), precipitação, oxidação, redução, adsorção, troca iônica, eletrodiálise e desinfecção. Os últimos são conseguidos por meio de atividades biológicas ou bioquímicas. Os processos biológicos podem ser aeróbios ou anaeróbios, tais como: lodos ativados, lagoas de estabilização, lagoas aeradas, filtros biológicos, biodiscos, reatores anaeróbios.

Bibiano (2013) afirma que, nas áreas urbanas, o potencial para a introdução de utilização de águas residuárias é bastante elevado, podendo desempenhar um papel significativo no controle do consumo de água, reduzindo sua carga poluente sobre o meio ambiente. Uma das soluções para o problema, segundo Almeida (2011), seria o tratamento de águas residuárias, também chamadas de águas recicladas, visto que um grande percentual de água utilizada para atividades urbanas não precisa de qualidade tão elevada como a da água potável.

Cada país define seus padrões aceitáveis de potabilidade. Fatores como os tempos de detenção e as taxas de diluição podem variar, bem como, consequentemente, a produção e a importância nos sistemas de distribuição. Por exemplo, em Cingapura ${ }^{9}$ a água passa por processo de microfiltração, osmose reversa e tecnologia ultravioleta e é usada principalmente na produção industrial, que será responsável por 70\% da demanda do país até 2060 .

Nos Estados Unidos, descargas de águas residuárias do reservatório das cidades de Occoquan e Fairfax County (Virgínia) representam 7\% do volume médio anual, aumentando para até 90\% em um ano de seca. Nos estados da Flórida e da Califórnia há redes de águas residuárias independentes, que se destinam à agricultura, rega de jardins públicos e gramados privados.

Conforme alertam Dantas e Sales (2009), os efluentes oriundos de estações de tratamento de esgotos, em alguns casos, podem ser uma alternativa inviável para uso na agricultura, a depender da origem das águas residuárias tratadas. Por exemplo, esgotos industriais não

\footnotetext{
${ }^{9}$ Segundo a ONU, a contribuição de águas residuárias na rede armazenada no sistema de Cingapura é de $30 \%$ do total disponível, podendo chegar a 55\% em 2060. Informação disponível em http://www.un.org/waterforlifedecade/winners2014.shtml.
} 
podem ser reutilizados para qualquer fim. Entretanto, de maneira geral, qualquer esgoto tratado tem aproveitamento para fins potáveis e não potáveis.

No mercado atual, uma solução prática para a adoção numa escala de edifícios públicos são as estações pré-fabricadas de tratamento de efluentes (ETEs). Tais sistemas devem atender as normas NBR 7229:1997, NBR 13969:1997 e NBR 12209:2011. Dentre as vantagens de uma ETE, é possível citar:

- Alta capacidade de remoção de carga orgânica;

- Processo muito mais econômico do que os métodos tradicionais;

- Alta resistência química e mecânica, evitando contaminação do lençol freático;

- Facilidade de instalação (equipamentos prontos, sem necessidade de montagens no local, podendo ser enterrados sem necessidade de paredes de contenção);

- Sistemas robustos com simplicidade e baixo custo operacional;

- Baixo impacto em ambientes urbanos (ruído, odor, visual);

- Vida útil do material em torno de 40 anos.

\subsection{Potencial de economia das TCAs}

No Brasil há vários fabricantes de equipamentos economizadores de água (EEAs), bem como de sistemas de tratamento de afluentes e efluentes, para atender os mais diversos setores e tipos de usuários. Nesses casos, há promessas dos fabricantes de grande economia de água em edificações.

$\mathrm{Na}$ fabricação de EEAs, as empresas de maior porte no mercado brasileiro sempre procuram desenvolver produtos com propostas inovadoras e que primem pela economia no consumo da água. Na maioria dos casos, a economia ocorre sem que o usuário necessite agir de forma diferenciada para que se obtenha a redução no consumo no momento da utilização.

Dentre os produtos do mercado nacional, as torneiras e mictórios de acionamento hidromecânico têm, segundo a NBR 13713 (2009), o tempo de abertura variando de 4 a 10 segundos, de acordo com a pressão do local, e geram até 55\% de economia em torneiras e até $80 \%$ em mictórios. O controle de vazão pode ser feito diretamente nas próprias peças, conforme manual de instalação que acompanha os produtos. O maior problema dessas peças é a desregulagem rápida dos acionadores e a maior exposição das peças a ação de vandalismo.

No caso de peças acionadas automaticamente por sensor, o tempo em que se posiciona o corpo (mictórios) ou as mãos (torneiras) é que vai definir o consumo, mas, em geral, o tempo 
de fechamento ocorre por volta de 2 segundos após o sensor não detectar mais a presença da pessoa. Segundo informações dos fabricantes, essa TCA economiza até $70 \%$ de água em torneiras e $80 \%$ em mictórios, além de garantir mais conforto e higiene aos usuários.

Há exemplos de vasos sanitários inteligentes, com sensores de ausência, em que o volume de água a ser liberada para o esgotamento dos dejetos é relacionado com o tempo pelo qual a pessoa utiliza a peça. Outra inovação recente é a torneira por sensor que é autônoma em energia, dado que possui um mecanismo interno de hidrogeração que utiliza a própria força da água para o funcionamento do sensor.

Quanto aos chuveiros, enquanto os fabricantes informam que as vazões médias giram entre 0,4 litro/segundo e 0,5 litro/segundo, a ANA (2005) amplia o intervalo para algo entre 0,2 litro/segundo e 0,8 litro/segundo. O INMETRO, que classifica os chuveiros quanto à eficiência energética, informa em seu sítio eletrônico intervalos de 3 litros/minuto a 5,8 litros/minuto (equivalente a 0,05 litro/segundo a 0,096 litro/segundo). Atualmente há no mercado chuveiros com restritores de pressão e acionamento com temporizador, que também reduzem o gasto de água sensivelmente.

A Tabela 2 apresenta a relação entre o consumo de água por um equipamento convencional e o consumo por um equipamento economizador, indicando a economia de água de um em relação ao outro.

Tabela 2 - Relação entre equipamentos convencionais e economizadores

\begin{tabular}{|c|c|c|c|c|}
\hline Equipamento convencional & $\begin{array}{c}\text { Consumo em } \\
\text { equipamento } \\
\text { convencional }\end{array}$ & $\begin{array}{c}\text { Equipamento } \\
\text { economizador }\end{array}$ & $\begin{array}{c}\text { Consumo de } \\
\text { equipamento } \\
\text { economizador }\end{array}$ & $\begin{array}{c}\text { Economia } \\
(\%)\end{array}$ \\
\hline $\begin{array}{c}\text { Bacia com caixa acoplada ou } \\
\text { válvula }\end{array}$ & 6 litros/descarga & $\begin{array}{c}\text { Duplo } \\
\text { acionamento }\end{array}$ & 6 e 3 litros/descarga & 25 \\
\hline $\begin{array}{c}\text { Ducha (quente + fria) de } \\
\text { baixa pressão (2 a 10 mca) }\end{array}$ & 0,22 litro/segundo & $\begin{array}{c}\text { Restritor de vazão } \\
6 \text { litros/minuto }\end{array}$ & 0,10 litro/segundo & 55 \\
\hline $\begin{array}{c}\text { Ducha (quente + fria) de alta } \\
\text { pressão (10 a } 40 \text { mca) }\end{array}$ & 0,34 litro/segundo & $\begin{array}{c}\text { Restritor de vazão } \\
6 \text { litros/minuto }\end{array}$ & 0,10 litro/segundo & 62 \\
\hline $\begin{array}{c}\text { Torneira de pia de baixa } \\
\text { pressão (2 a } 10 \text { mca) }\end{array}$ & 0,20 litro/segundo & $\begin{array}{c}\text { Arejador de vazão } \\
1,8 \text { litros/minuto }\end{array}$ & 0,03 litro/segundo & 85 \\
\hline $\begin{array}{c}\text { Torneira de pia de alta } \\
\text { pressão (10 a } 40 \text { mca) }\end{array}$ & 0,38 litro/segundo & $\begin{array}{c}\text { Arejador de vazão } \\
1,8 \text { litros/minuto }\end{array}$ & 0,03 litro/segundo & 92 \\
\hline $\begin{array}{c}\text { Torneira para uso geral de } \\
\text { baixa pressão (2 a } 10 \text { mca) }\end{array}$ & 0,23 litro/segundo & $\begin{array}{c}\text { Restritor de vazão } \\
6 \text { litros/minuto }\end{array}$ & 0,10 litro/segundo & 57 \\
\hline $\begin{array}{c}\text { Torneira para uso geral de } \\
\text { alta pressão (10 a } 40 \text { mca) }\end{array}$ & 0,38 litro/segundo & $\begin{array}{c}\text { Restritor de vazão } \\
6 \text { litros/minuto }\end{array}$ & 0,10 litro/segundo & 74 \\
\hline Mictório & 2 litros/uso & $\begin{array}{c}\text { Válvula } \\
\text { automática }\end{array}$ & 1 litro/uso & 50 \\
\hline
\end{tabular}

Fonte: Tomaz (2010) e Hafner (2007) - adaptado

\footnotetext{
${ }^{10}$ Nesse caso, o valor estipulado corresponde à média aritmética entre os dois autores pesquisados.
} 
Ressalte-se que vários fabricantes já incorporaram os arejadores às suas linhas de torneiras, mas, na maioria das vezes, nas linhas mais sofisticadas. No caso das linhas básicas de produtos novos e no caso de substituição de modelos antigos, a troca por arejadores é recomendável. De acordo com Marinoski e Andrade (2010), o uso do arejador traz uma redução de cerca de 50\% do valor da vazão nas mesmas condições de uso. De acordo com a NBR 10281 (2003), uma torneira dotada de arejador deve apresentar vazão mínima de 0,05 litro/segundo.

No que tange ao reúso de águas cinzas e residuárias, há na literatura vários relatos de comprovação da viabilidade econômica desses sistemas, em vários tipos de edificações, com frequências e em locais distintos.

Fasola et al. (2011) informa, em um estudo em edifícios escolares, que o potencial de economia de água variou de $27,8 \%$ a $72,7 \%$, combinando equipamentos economizadores e aproveitamento de água pluvial. Nunes (2006), numa pesquisa de conservação de água em edifícios comerciais, especificamente em shopping centers, encontrou um valor total de redução em torno de 17\%, destacando também preocupação com o uso de águas residuárias tratadas, especialmente pela qualidade da água, visto que pode provocar incrustações, corrosão metálica e crescimento biológico em equipamentos de ar-condicionado.

Entre os edifícios residenciais, Aguiar e Gonçalves (2011) pesquisaram o potencial de conservação de água com a prática do tratamento de águas cinzas em um edifício residencial e concluíram que, a depender do cenário proposto, uma economia de água potável de $16 \%$ poderia ser atingida. Sant'Ana et al. (2013), em estudo direcionado às superquadras de Brasília, concluíram que o custo-benefício dos sistemas AAP demonstraram ser alternativas mais viáveis para adaptação predial que os de TACs e TARs, por apresentarem custos de investimento menores.

No campo das universidades, Salla et al. (2013), que estudaram a viabilidade técnica de implantação de sistema de aproveitamento de água pluvial para fins não potáveis em universidade, registraram um potencial de economia de água potável entre 18,2\% e 53,2\%. Almeida (2009) destaca que, com campanhas de conscientização de usuários quanto ao uso racional de água, os resultados em um campus universitário chegaram a uma redução do consumo de água da ordem de $11 \%$, a partir de incentivos visuais, de divulgação de conhecimentos e de conscientização a favor de sua conservação e uso racional. 
Quanto aos prédios públicos administrativos, o único estudo encontrado foi o de Kammers e Ghisi (2006), que indica que aproximadamente $77 \%$ da água potável utilizada nos edifícios públicos analisados poderiam ser substituídos por água pluvial ou por tratamento de águas cinzas, ou pela combinação de ambas.

Do ponto de vista econômico, a revisão bibliográfica assegura que há vantagem econômica em diversos casos de implantação de TCAs em edifícios de várias funções. Nesta pesquisa não há o propósito de se avançar nessa questão, mas tão somente demonstrar que, no caso de órgãos públicos, com um estudo completo de tempo de retorno do investimento financeiro, não seria difícil convencer os tomadores de decisão a apoiar tecnicamente a ideia de implantação de TCAs.

O que se pressupõe que ocorra na área técnica dos órgãos públicos, apesar de alguns movimentos de conscientização, é um desconhecimento da viabilidade técnica e econômica de algumas soluções. Também pesa nesse cenário o preconceito acerca da necessidade do investimento em si, pois a insegurança de propagação de doenças de transmissão pela água ainda é grande.

Por outro lado, devido à crise hídrica que assola importantes estados brasileiros desde 2014, alguns órgãos sentem-se confortáveis para tomar decisões de implantação de soluções com viabilidade econômica apenas em longo prazo, mas que são ambientalmente importantes.

\subsection{Síntese analítica do capítulo 2}

O capítulo 2 traz uma pesquisa sobre as tecnologias conservadoras de água (TCAs) disponíveis e as que podem ser utilizadas em soluções para redução do consumo de água em prédios públicos, como a hidrometração unitária, os equipamentos economizadores de água, o aproveitamento de águas pluviais e o tratamento de águas cinzas e residuárias.

No que tange à hidrometração unitária, percebe-se que é um sistema de controle que provoca, na maioria dos casos, uma mudança de postura dos usuários e consequente redução de consumo. No prisma dos edifícios públicos, há algumas considerações a se fazer:

- Essa solução pode não provocar motivação suficiente para os tomadores de decisão, dado que as contas de água são pagas de forma conjunta, relativas ao consumo de todos os sanitários das edificações;

- Considerando a possibilidade de hidrometração unitária em edifícios públicos e o interesse do dirigente da instituição, a instalação de hidrômetros por sanitário ou conjunto de 
sanitários (e copas, como no caso do TCU) contíguos é interessante para o órgão, pois traz um controle mais preciso dos gastos de cada unidade medida e serve como uma ferramenta de grande auxílio às equipes de manutenção preventiva, gerando ações mais tempestivas e eficientes;

- Como o fator econômico tem um peso muito relevante na decisão dos gestores públicos, há que se considerar que o retorno de um investimento que tem o objetivo principal de controle do consumo, com a economia deste consumo como consequência indireta, parece ser inovador o suficiente para uma mudança de postura.

Quanto ao uso de equipamentos economizadores de água, a pesquisa demonstrou, por critérios bem objetivos (vide item 2.5 e Tabela 2 - pp. 95 e 96), que a economia de água efetivamente ocorre. Não foi tratado o tema do retorno financeiro desse investimento com eventuais trocas de materiais, mas é clara a importância que é dada pelo setor industrial aos equipamentos de uso público, com especial atenção a soluções antivandalismo.

Como se trata em muitos casos de tecnologia pela qual o usuário não necessita mudar sua postura nem a frequência de uso das instalações sanitárias, tal solução configura-se como adequada aos edifícios públicos, recomendando-se o investimento pelos gestores, desde que disponível orçamento para tanto. Destacam-se neste cenário soluções como os aeradores dos chuveiros, que inserem ar com a água para a manutenção da sensação de conforto no banho; ou os mictórios sem uso de água, que aparecem como solução definitiva para esse consumo específico, não gerando odores e reduzindo o custo de instalação e de manutenção.

No que concerne às tecnologias de aproveitamento de águas pluviais, existem indústrias brasileiras que produzem soluções completas. A depender do regime de chuvas do local instalado, o aproveitamento pode ser muito eficiente, com necessidade de volumes reduzidos de reservação e baixos custos de implantação.

Por se tratar de solução de conservação de água em que o retorno dos investimentos é rápido [Alves (2010); Sant'Ana et al. (2013)], a instalação não é complexa e seu uso é indicado para serviços e locais muito utilizados em edifícios públicos, como irrigação de jardins, caixas acopladas de vasos sanitários, lavagem de veículos e pisos e sistemas de ar condicionado e de incêndio [Alves (2010); Tomaz (2009)], assim como sua implantação deve ser incentivada pelos responsáveis pela gestão de projetos e de manutenção predial. 
O dimensionamento dos reservatórios deve seguir as normas brasileiras, e a operação do sistema é simples, não necessitando de ajustes nas equipes de manutenção dos órgãos públicos. May (2009) ressalta que são sistemas de fácil manuseio, custo de implantação baixo e viabilidade econômica favorável em regiões com precipitação elevada.

A literatura afirma, na maioria dos casos, que há um retorno financeiro do investimento, fato que pode convencer gestores acerca da implantação destas soluções. Sant'Ana (2011), por exemplo, comprova a viabilidade econômica de implantação de sistemas de aproveitamento de águas pluviais, ressaltando que os benefícios ambientais devem ser considerados.

Quando se trata de tecnologias de tratamento de águas cinzas e residuárias, a literatura registra uma série de soluções para cada caso. Segundo May (2009), os sistemas devem seguir quatro critérios: segurança higiênica, estética, proteção ambiental e viabilidade técnica e econômica. A mesma autora cita condicionantes importantes a serem consideradas, como tipologia da edificação, localidade, nível de ocupação, cultura e costume dos usuários. O investimento financeiro de uso de águas cinzas tratadas, segundo Sant'Ana (2013), para cenários de reaproveitamento em descargas sanitárias, é viável em prédios residenciais multifamiliares.

Pela tipologia e morfologia de prédios públicos administrativos, com grandes áreas de escritório e grande rotatividade dos equipamentos sanitários, pode-se recomendar que os gestores públicos invistam em pesquisas com vistas à instalação de sistemas de águas cinzas, desde que atendidas a regulação brasileira para consumo de águas não potáveis e que se encaixe nos orçamentos de cada instituição.

As águas residuárias podem ser tratadas, pela versatilidade de soluções, com sistemas que incluem estações modulares de tratamento de esgoto. Nesse caso, há um ganho ambiental, pois não há lançamento na rede pública de esgotos, além de ganho financeiro, pois há uso total dessas águas residuárias.

Especial atenção deve ser dada aos requisitos para dimensionamento desses sistemas, que devem considerar, em prédios públicos administrativos, segundo empresas do ramo, a quantidade de usuários, incluindo funcionários e visitantes ao longo do ano; a quantidade de refeições servidas, em caso de presença de restaurantes ou lanchonetes; se há cozinha própria; a quantidade de banhos por dia, em caso de presença de vestiários; qual é o órgão fiscalizador ambiental e qual é o destino do efluente tratado. Cabe, portanto, a cada tomador de decisões, a análise do custo-benefício desse tipo de tratamento. 


\section{CAPÍTULO 3 - PROGRAMAS DE CONSERVAÇÃO DE ÁGUA}

Segundo ANA et al. (2005), a metodologia para a implantação de um Programa de Conservação de Água (PCA), com ênfase na gestão da oferta e da demanda de água em edificações existentes, está estruturada em três etapas: auditoria e diagnóstico do consumo de água, definição e execução do plano de intervenção e implantação de um sistema de gestão.

Por outro lado, o Ministério do Meio Ambiente (MMA, 2014) entende que há seis etapas: avaliação técnica preliminar, avaliação da demanda de água, avaliação da oferta da água, estudo de viabilidade técnica e econômica, detalhamento técnico e sistema de gestão. Essa publicação afirma que os PCAs atuam diretamente sob o usuário final, incentivando a redução do consumo de água por meio da adoção de medidas de uso racional da água potável (demanda) e de fontes alternativas de água (oferta) para fins menos nobres que não necessitam de água potável.

O mesmo autor acrescenta ainda que, com a redução da demanda de água, tem-se também a redução do volume de esgoto, barateando o custo de operação das estações de tratamento de água e de esgoto, tornando viável um maior investimento em infraestrutura. Dessa forma, as concessionárias conseguem atender a um número maior de pessoas, garantindo a excelência na prestação dos serviços.

ANA et al. (2005), por sua vez, explicam que um PCA implantado de forma sistêmica implica em otimizar o consumo de água com a consequente redução do volume dos efluentes gerados, a partir da otimização do uso (gestão da demanda) e da utilização de água com diferentes níveis de qualidade para atendimento das necessidades existentes (gestão da oferta).

O detalhamento das ações e produtos que ANA et al. (2005) e MMA (2014) entendem necessários para a perfeita execução de um PCA está mostrado no Quadro 19, no qual se consolidou uma matriz ampla, com as atividades entendidas como mais relevantes para a sistematização de PCAs em edifícios públicos. Como os conteúdos, na prática, eram muito próximos, as etapas de cada uma das publicações foram associadas e consolidadas às ações e produtos esperados, com as devidas adaptações.

$\mathrm{Na}$ fase de definição de ações do plano de intervenção, deve-se ter atenção ao aspecto de qualidade da água, mesmo que para uso não potável, visto que o Ministério da Saúde (2011) alerta em alguns trechos de sua legislação sobre o aspecto de risco à saúde humana. Florencio et. al. (2006) afirmam que a conceituação de risco está relacionada à caracterização de 
relações entre a exposição a determinados agentes e os potenciais danos causados à saúde humana, possibilitando a previsão de eventos em saúde em uma população exposta.

Quadro 19 - Ações de um Programa de Conservação de Água

\begin{tabular}{|c|c|c|c|}
\hline $\begin{array}{c}\text { Etapas } \\
\text { ANA } \text { et al. } \\
(2005) \\
\end{array}$ & $\begin{array}{l}\text { Etapas } \\
\text { MMA } \\
(2014) \\
\end{array}$ & Ações & Produtos \\
\hline \multirow{3}{*}{$\begin{array}{l}\text { Auditoria e } \\
\text { diagnóstico do } \\
\text { consumo }\end{array}$} & $\begin{array}{l}\text { Avaliação técnica } \\
\text { preliminar }\end{array}$ & \multirow{3}{*}{$\begin{array}{l}\text { Análise do consumo histórico dos } \\
\text { últimos } 36 \text { meses; levantamento do } \\
\text { edifício e usuários; caracterização } \\
\text { dos usos finais de água; cálculo do } \\
\text { indicador de consumo; definição } \\
\text { dos pontos que necessitam de ações } \\
\text { de conservação de água. }\end{array}$} & \multirow{3}{*}{$\begin{array}{l}\text { Plano de setorização do consumo de } \\
\text { água; macro e micro fluxos de água; } \\
\text { plano de adequação de equipamentos } \\
\text { hidráulicos; plano de adequação de } \\
\text { procedimentos; plano de otimização } \\
\text { de sistemas; plano de aplicação de } \\
\text { fontes alternativas de água. }\end{array}$} \\
\hline & $\begin{array}{c}\text { Avaliação da } \\
\text { demanda de água }\end{array}$ & & \\
\hline & $\begin{array}{l}\text { Avaliação da } \\
\text { oferta de água }\end{array}$ & & \\
\hline \multirow[t]{2}{*}{$\begin{array}{c}\text { Plano de } \\
\text { intervenção }\end{array}$} & $\begin{array}{l}\text { Estudo de } \\
\text { viabilidade } \\
\text { técnica e } \\
\text { econômica }\end{array}$ & \multirow{2}{*}{$\begin{array}{l}\text { Análise técnico-econômica } \\
\text { preliminar; indicação de } \\
\text { investimentos para monitoramento } \\
\text { eficiente dos sistemas; definição de } \\
\text { estratégias de uso racional de água; } \\
\text { recomendações de usos não } \\
\text { potáveis de água. }\end{array}$} & \multirow{2}{*}{$\begin{array}{l}\text { Indicação de cenário ótimo de } \\
\text { conservação de água no edifício; } \\
\text { especificação técnica e orçamento de } \\
\text { equipamentos e soluções disponíveis } \\
\text { no mercado; projeto executivo dos } \\
\text { sistemas recomendados. }\end{array}$} \\
\hline & $\begin{array}{l}\text { Detalhamento } \\
\text { técnico }\end{array}$ & & \\
\hline $\begin{array}{l}\text { Sistema de } \\
\text { gestão }\end{array}$ & Sistema de gestão & $\begin{array}{l}\text { Avaliação constante do impacto de } \\
\text { redução; treinamento e capacitação } \\
\text { de profissionais envolvidos com a } \\
\text { gestão de água; lançamento de } \\
\text { campanhas educativas; revisão } \\
\text { periódica das rotinas, } \\
\text { procedimentos e indicadores; } \\
\text { modernização de sistemas. }\end{array}$ & $\begin{array}{l}\text { Sistema de gestão de água } \\
\text { implantado. }\end{array}$ \\
\hline
\end{tabular}

Fonte: ANA et al. (2005) e MMA (2014) - adaptado

\subsection{Setorização de consumo}

A primeira característica do sistema hidráulico que deve ser verificada, segundo ANA et al. (2005), é a existência de medição de consumo de água. Em caso positivo, recomenda-se o início da auditoria de consumo de água. Em caso negativo, deve-se tomar providências para a implantação de um sistema de hidrometração unitária ou setorizada. Como comentado no capítulo anterior, o recomendável para edifícios públicos é que haja uma setorização por andar ou por conjunto de áreas molhadas pertencentes à mesma prumada.

A adoção de um sistema de medição setorizada do consumo de água, preferencialmente com a emissão de dados de forma remota, traz como principal benefício o controle de consumo, possibilitando a avaliação de sistemas ou equipamentos instalados, o monitoramento diário dos sistemas hidráulicos dos edifícios e a pronta localização de vazamentos que levariam meses ou até anos para serem identificados.

Nos casos em que há conjuntos de edifícios com diferentes usos e usuários, de acordo com a ANA et al. (2005), características específicas podem ser atribuídas para cada ponto de 
medição e sua área de cobertura, de acordo com a tipologia envolvida, o período do uso da água e o perfil de demanda, tornando possível a rápida detecção de anomalias no sistema.

Tal arranjo, no caso de prédios públicos administrativos, torna-se difícil em muitos casos, dado que a morfologia dos edifícios e a disposição dos conjuntos de sanitários e copas muitas vezes se repetem. No caso em que houver restaurantes ou lanchonetes (ou ambos) dentro do espaço edificado, essa distinção de medição de água pode ser benéfica para fins de controle de consumo.

Nas edificações existentes, especialmente as mais antigas, a setorização da medição do consumo é normalmente difícil de implantar, pois os sistemas prediais de água eram usualmente concebidos de forma verticalizada, com colunas de distribuição que abasteciam pontos de consumo em ambientes sobrepostos, por meio de tubulações quase sempre embutidas nas paredes.

Por outro lado, em edificações de execução mais recente, onde o sistema predial de água tenha sido executado de forma visitável, com as tubulações passando em dutos com fechamento removível e/ou em vãos proporcionados pelo emprego de shafts ou forros modulares, entre outros artifícios, a setorização do consumo pode ser facilitada, dado que a instalação de submedidores é mais simples.

A recomendação de hidrometração, por sua vez, não é citada de forma explícita pelo MMA (2014), que entende que um dos produtos da análise técnica preliminar (primeira fase do PCA), é um plano de setorização do consumo de água. Como essa publicação é direcionada para edifícios públicos, a setorização é considerada a única opção de hidrometração de controle, cabendo aos gestores a decisão de setorização por edifício (em caso de análise de conjunto de edifícios) ou por andar ou prumada (em caso de análise individual).

\subsection{Auditoria do consumo de água}

A análise do consumo permite o conhecimento da utilização da água no sistema, por meio do planejamento adequado para a realização de levantamento documental, das características físicas e funcionais do edifício e, em particular, do sistema hidráulico, conforme afirma a ANA et al. (2005). Nessa fonte é proposto o levantamento do Indicador de Consumo (IC), que é definido como a relação entre o volume de água consumido em um determinado período, denominado período histórico, e o número de agentes consumidores nesse mesmo período. 
O agente consumidor é a variável mais representativa do consumo em uma determinada tipologia de edificação. O parâmetro adotado para expressar o IC varia em função da tipologia do edifício (ANA et al., 2005). Assim, por exemplo, em um edifício residencial ou de escritórios, é utilizado o parâmetro de litros/pessoa/dia; em uma escola, litros/aluno/dia; em um hospital, litros/leito/dia. Esses valores constituem referências para a avaliação do impacto de redução do consumo de água após cada uma das ações executadas no decorrer de um PCA. A adoção, por exemplo, da área total construída na definição de indicadores de consumo poderá incorrer em erros significativos em prédios públicos, pois em alguns casos há extensas áreas ocupadas com garagens subterrâneas. No caso de prédios públicos administrativos, as áreas de escritórios parecem ser variáveis mais apropriadas, justamente pelo próprio fim a que se destinam.

É de fundamental importância que, por meio dessa auditoria, se obtenham dados primários confiáveis dos edifícios estudados. Os dados devem englobar necessariamente a população que os utiliza, a área dos edifícios (construída e de cobertura), a distribuição dos pontos de utilização e o efetivo consumo de água. Kammers e Ghisi (2006) e Proença e Ghisi (2009) inseriram na metodologia de seus trabalhos levantamentos do consumo real, com dados das concessionárias de água, levantamentos de campo (por meio de entrevistas) e estimativas de consumo de água nos edifícios.

Para o conhecimento das características físicas e funcionais do sistema hidráulico e das atividades desenvolvidas no edifício, é necessária a realização de um levantamento geral do sistema nas edificações existentes. As informações obtidas nessa etapa contribuem para o entendimento do perfil de consumo de água no sistema. O levantamento do edifício é realizado por meio das seguintes atividades: levantamento dos sistemas hidráulicos prediais e especiais, da qualidade da água e dos procedimentos dos usuários, bem como a detecção dos vazamentos visíveis e não visíveis ${ }^{11}$. Esse levantamento também pode ser chamado de vistoria hidráulica.

Tanto ANA et al. (2005) quanto MMA (2014) preveem a execução de ações na etapa do levantamento do sistema hidráulico predial, para que caracterizem precisamente o uso da água no edifício e subsidiem a avaliação preliminar da auditoria de consumo. De forma sintética, as tarefas recomendadas são:

\footnotetext{
${ }^{11}$ A detecção dos vazamentos não visíveis pode ser feita a partir da realização de testes expeditos, como o teste da caneta em bacias sanitárias ou o teste do hidrômetro.
} 
- Levantar a idade da edificação, o número de usuários e os projetos hidráulicos, arquitetônicos e de layout;

- Levantar o histórico do consumo de água (12 meses ou mais);

- Levantar o histórico de manutenção do sistema hidráulico, rotinas, procedimentos e custos operacionais;

- Cadastrar o tipo do sistema de abastecimento e o número de medidores e equipamentos;

- Monitorar a pressão em pontos críticos do sistema;

- Cadastrar os pontos de utilização do sistema, características e condições de operação;

- Descrever planos e programas futuros, referentes à expansão e reformas.

Para o caso de edifícios públicos administrativos, os sistemas hidráulicos considerados especiais que mais serão contabilizados serão os do sistema de ar condicionado. As características técnicas dos equipamentos, como vazão, período diário de operação e consumo de água no processo devem ser cadastradas para se obter uma estimativa do percentual de participação do sistema no consumo total. Deve-se identificar, também, a ocorrência de perdas de água por vazamento em bombas, drenos, tubulações e outros componentes.

No que concerne à etapa de levantamento da qualidade da água, é recomendada a realização de análise físico-química e bacteriológica da água, com descrição de metodologia e a identificação de pontos do sistema hidráulico com potencial de contaminação da água. Em caso de contaminação, devem ser identificadas as possíveis causas, como, por exemplo, resíduos provenientes de tubulações, falhas na filtração ou desinfecção de sistemas, problemas de contaminação no abastecimento da concessionária, entre outros.

O Ministério do Meio Ambiente (2014) recomenda nesta fase a análise da possibilidade de uso de fontes alternativas de água, como mostra o Quadro 20.

Quadro 20 - Exemplos de fontes alternativas de água

\begin{tabular}{|c|c|}
\hline Fonte & Características \\
\hline $\begin{array}{l}\text { Água de drenagem de } \\
\text { terrenos }\end{array}$ & $\begin{array}{l}\text { Decorrentes de alguma intervenção no subsolo, como no caso de construção de } \\
\text { garagens subterrâneas. }\end{array}$ \\
\hline $\begin{array}{l}\text { Água de reúso de } \\
\text { concessionárias }\end{array}$ & $\begin{array}{l}\text { Proveniente do tratamento do esgoto coletado no setor urbano, com custos } \\
\text { inferiores ao da água potável, tornando uma opção a ser considerada, tanto do } \\
\text { ponto de vista ambiental quanto econômico. }\end{array}$ \\
\hline Águas subterrâneas & $\begin{array}{l}\text { Apresentam algumas propriedades que tornam seu uso mais vantajoso em relação } \\
\text { ao uso das águas superficiais, como pureza, menor influência climática, } \\
\text { temperatura constante e pouco uso de área superficial, entre outras. }\end{array}$ \\
\hline
\end{tabular}

Fonte: MMA (2014) - adaptado 
O levantamento dos usos finais de água deve ser realizado com a maior discrição possível, para que os usuários não mudem de comportamento e, assim, possam mascarar as informações que deverão ser repassadas ao profissional responsável por uma futura campanha educativa.

Além da observação dos usuários, quando da realização das principais atividades, podem ser feitas entrevistas com usuários-chave, levantando a forma de realização das diferentes atividades. A entrevista pode ser aproveitada, inclusive, para se verificar a satisfação dos usuários com os aparelhos sanitários existentes e os sistemas que utilizam água, obtendo assim subsídios para ações futuras.

\subsection{Diagnóstico do consumo de água}

O diagnóstico é a síntese organizada das informações obtidas na auditoria do consumo de água. Ele possibilita a elaboração de um plano de intervenção com ações específicas para cada tipologia de edifício e a consideração das características próprias de cada sistema. ANA et al. (2005) recomendam que, após a conclusão do levantamento do sistema e do processamento dos dados, deve-se elaborar o diagnóstico, apresentando as condições de operação, as perdas de água provenientes de vazamentos, inclusive dos sistemas hidráulicos especiais. Os mesmos autores recomendam que informações relativas ao período histórico, dentre as relacionadas a seguir, constem da apresentação do diagnóstico do consumo de água:

- Consumo diário de água no período histórico ( $\left.\mathrm{m}^{3} / \mathrm{ano}\right)$;

- Consumos específicos por tipo de uso ( $\mathrm{m}^{3} / \mathrm{usuário} \mathrm{e} \mathrm{m}^{3} / \mathrm{m}^{2}$ de áreas irrigadas, p. ex.)

- Número de agentes consumidores, com separação por função, se possível (servidores, terceirizados, estagiários, visitantes);

- Usos finais de água;

- Indicadores de consumo de água no período histórico (litros/pessoa/dia ou litros/ $/ \mathrm{m}^{2} / \mathrm{dia}$ );

- Desperdício diário estimado, informando perdas por vazamento visível e invisível, se detectável (litros/dia);

- Ineficiências e pontos críticos de consumo;

- Procedimentos e hábitos de consumo dos usuários, relacionados ao consumo de água.

\subsection{Caracterização dos usos finais de água}

A importância de se estabelecer um perfil do uso final de água em edifícios públicos administrativos reside no fato de o Brasil carecer de instrumentos que auxiliem na tomada de 
decisão de gestores públicos quando se refere ao tema de eficiência hídrica em edifícios. Tal caracterização gera dados qualitativos que possibilitam implantar estratégias futuras de redução no consumo, como, por exemplo, o uso de TCAs.

O uso final da água, para o caso de edifícios públicos administrativos, oscilará em função da população que a utiliza e das áreas totais dos ambientes com instalações de água. Kammers e Ghisi (2006) afirmam que, independentemente das estratégias adotadas para se reduzir o consumo de água potável, o conhecimento dos usos finais de água na edificação é essencial para que se possam adotar estratégias adequadas de redução do consumo de água.

A forma mais objetiva de se obter uma radiografia precisa do uso final de água de edifícios públicos é a informação do usuário. Kammers e Ghisi (2006) e Proença e Ghisi (2009) trabalharam com uma metodologia em que são levantadas as características dos dispositivos utilizados e a frequência com que eles são utilizados.

Pesquisas aprofundadas nesse tema podem auxiliar o Governo Federal a definir políticas públicas em caráter nacional que promovam a economia de água em larga escala em edifícios públicos, que representam uma parcela significativa do universo da cadeia produtiva da indústria da construção (CPIC). Tais políticas também podem incentivar fabricantes envolvidos com esse ramo da construção civil a desenvolverem produtos cada vez mais eficientes e com preços acessíveis à população.

Na presente pesquisa foram levantados os usos finais da população do conjunto edificado do Tribunal de Contas da União, lotada em Brasília/DF, cuja metodologia está discriminada no próximo capítulo. Esses dados são fundamentais para a percepção do padrão de consumo de água de uma determinada população e servem como base para a determinação de ações futuras na conservação de água de edifícios.

\subsection{Plano de intervenção}

A partir do diagnóstico realizado, pode-se elaborar o plano de intervenção, cujas ações devem ser iniciadas pelo ponto crítico do sistema, que, em geral, se dá pela correção dos vazamentos detectados. De acordo com a ANA et al. (2005), na execução de um plano de intervenção para reduzir o consumo de água, é indispensável a avaliação das ações implementadas, que pode ser feita após a implantação de cada uma delas ou no final do plano de intervenção.

Esse plano consiste, segundo o MMA (2014), na elaboração da matriz de soluções e na análise técnica e econômica para avaliação da viabilidade de ações e medidas a serem 
incorporadas no planejamento do programa de conservação da água. Tal avaliação pressupõe analisar os custos correspondentes, tanto em relação ao investimento inicial quanto os relativos à operação e manutenção, bem como, em paralelo, os benefícios associados.

O mesmo autor acrescenta ainda que as ações devem ser descritas considerando: a) o cronograma de implantação das atividades para compatibilização com o orçamento disponível; b) a especificação do sistema de setorização para monitoramento do consumo, se for o caso; c) o detalhamento de cada intervenção (elementos gráficos e descritivos); d) a especificação de sistemas, materiais e equipamentos a serem instalados; e) a elaboração de procedimentos para as atividades consumidoras de água contempladas pelo programa; e f) os manuais de manutenção e operação dos sistemas e equipamentos.

Oliveira e Gonçalves (1999) acrescentam que as ações de conservação da água em edificações podem ser divididas em três categorias, conforme o Quadro 21.

Quadro 21 - Tipos de ações de um plano de intervenção de um PCA

\begin{tabular}{|c|l|}
\hline Ação & \multicolumn{1}{c|}{ Exemplos de aplicação } \\
\hline Social & Adoção de campanhas educativas e sensibilização das pessoas. \\
\hline Econômica & $\begin{array}{l}\text { Incentivos financeiros com a redução de tarifas e subsídios para a aquisição de sistemas e } \\
\text { componentes economizadores de água, concomitante à aplicação de sanções para inibir o } \\
\text { desperdício, como o aumento da tarifa de água em função das faixas de consumo. }\end{array}$ \\
\hline Tecnológica & $\begin{array}{l}\text { Utilização de sistemas e componentes economizadores de água, detecção e correção de } \\
\text { vazamentos e sistemas de medição setorizada do seu consumo. }\end{array}$ \\
\hline
\end{tabular}

Fonte: Oliveira e Gonçalves (1999)

A sensibilização e/ou o treinamento dos usuários para a conservação de água potencializa outras ações que venham a ser adotadas dentro de um PCA. A campanha de sensibilização, que é uma comunicação mais abrangente, tanto do ponto de vista de informação quanto do tipo de usuário, destinada a todos os usuários do sistema, pode abordar tópicos como:

- O objetivo da conservação da água;

- As vantagens econômicas e ambientais da redução de volume de água e de esgoto tratado;

- A redução de gastos com as contas de água e de energia;

- A possibilidade de atendimento a um maior número de usuários.

Tais programas auxiliam na formação de gerações que praticam e vivem a sustentabilidade no seu modo mais direto. Esse público pode levar essas lições a seus familiares e amigos e perpetuar a ideia do cuidado com a conservação da água para as futuras gerações. Esses usuários conscientes podem também auxiliar numa eventual necessidade de mudança de 
postura dos governos, bem como alertar acerca da devida importância do gasto público com responsabilidade.

A campanha educativa, por sua vez, é uma forma de comunicação destinada a usuários específicos e desenvolvida por meio de palestras dirigidas aos funcionários de cozinha e lanchonete, de laboratório, de limpeza, de manutenção de sistemas prediais e a outros grupos de usuários consumidores de água no sistema, informando-os de procedimentos mais adequados para a realização de suas atividades.

Essa ação deve ser conduzida, como exemplifica ANA et al. (2005), por profissionais especialistas de cada uma das áreas, com desenvolvimento de atividades como:

- Curso de pesquisa de vazamento e de manutenção de sistemas prediais, ministrado pelas concessionárias ou outras entidades;

- Palestras sobre procedimentos para higienização de utensílios de cozinha e preparação de alimentos;

- Palestras que abordem procedimentos de limpeza em geral, limpeza de reservatórios e irrigação de jardins.

As ações econômicas recomendadas em um plano de intervenção tendem a ser muito eficientes em qualquer tipo de edificação, visto que geram sanções para os que gastam demasiadamente e incentivam aqueles que prezam pela economia de água. Em alguns casos a iniciativa dessas ações parte do próprio Poder Público. Entretanto, o plano de intervenção pode recomendar a aplicação de sanções internas administrativas quando for comprovado o descaso com o uso do bem público, facilmente tipificado na Lei nº 8.666/1993.

As ações tecnológicas a serem adotadas são detalhadas de acordo com as metas de redução estabelecidas e a disponibilidade de investimento, sendo que, muitas vezes, a implantação dessas ações é gradual, de maneira que as economias geradas por cada ação viabilizem a ação seguinte prevista no programa (MMA, 2014).

\subsection{Experiência internacional}

Neste item foi levantado o estado da arte acerca de programas de conservação de água em alguns países no mundo, com o objetivo de identificar ações e processos utilizados em edifícios públicos e comerciais e que tenham potencial para ser incorporados aos métodos definidos em ANA et al. (2005) e MMA (2014). 
Foi tentado traçar um paralelo com as recomendações brasileiras no que concerne às etapas definidas no Quadro 19. Todavia, como as informações coletadas nesta pesquisa não estavam detalhadas, optou-se pela itemização dos tópicos de gestão de água mais frequentes na literatura internacional, como os vazamentos em tubulações, a setorização ou individualização de medição e o uso de indicadores de consumo de água.

Em muitos países pesquisados, especialmente Austrália, Nova Zelândia, EUA, Canadá, Índia e alguns da Europa, existe uma preocupação com o estabelecimento de regras específicas para a conservação de água em edifícios públicos e comerciais, posto que eles têm características gerais bem semelhantes. Tais regras também passam pelo desenvolvimento de programas de conservação de água, comumente chamados nesses países de planos de gestão ou planos de ação.

Na Europa, a implantação desses planos tem evoluído no sentido de possibilitar uma classificação em uma auditoria, que inclui uma série de requisitos mínimos que um edifício tem que cumprir em relação ao desempenho de água. Entre as possibilidades de parâmetros a serem mensurados, estão o uso total de água no edifício, o uso de água dividido pela área do edifício ou pelo número de usuários, bem como o número de dispositivos eficientes de água. (Real Property Association of Canada, 2011; Australian Government, 2006).

Há uma tendência de essas práticas serem incorporadas aos rótulos ecológicos já consolidados no mundo, conforme já descrito no Quadro 7 (p. 50). Iniciativas isoladas têm buscado possíveis compatibilizações que possam ser consolidadas para construir um sistema europeu comum. Baseado nas informações da Environment Directorate-General of the European Commission (2011), elas trariam um valor agregado aos sistemas, por meio da implantação em toda a Europa das mesmas exigências básicas de melhoria. A busca das experiências dos países que investem na aplicação desse tipo de gestão pode auxiliar na consolidação dessa prática no Brasil.

Na maioria dos países estudados, há a recomendação expressa para que sejam desenvolvidos planos (e não programas) para o gerenciamento da água em edifícios. Tais planos fazem parte de estratégias públicas de conservação de água no ambiente urbano, reflexo de políticas que tentam aumentar a oferta nos recursos hídricos disponíveis juntamente com tentativas de redução da demanda. 
Dentre os países com maior destaque nas políticas públicas de conservação de água em edifícios, vale destacar o empenho do governo australiano em buscar uma gestão eficaz da água, que não pode ser alcançada sem um meio de aferição do desempenho desses edifícios (ANAO - Australian National Audit Office, 2012). A Austrália possui também um guia específico de eficiência da água em edifícios públicos e comerciais (Australian Government, 2006).

No Canadá, a Real Property Association of Canada (2011) tem uma literatura acerca dos indicadores de usos de água e que orienta gestores de edifícios comerciais. $\mathrm{O}$ documento dispõe que as empresas e órgãos públicos devem seguir uma abordagem simples para planejar as ações e avaliar os riscos associados à água. Os gestores devem medir o desempenho, planejar melhorias e comparar com referências de consumo previamente aceitas.

A Índia, por sua vez, possui uma publicação que define as principais orientações sobre conservação e auditoria de água em edifícios. O governo indiano entende que ações simples podem ser aplicadas em prédios públicos, chegando a aconselhar o uso de canecas para a escovação dos dentes e o uso de copos menores para beber água, de forma a evitar o desperdício. Percebe-se, portanto, que a realidade social do país muda o foco das recomendações e que elas procuram retratar o cotidiano dos usuários de forma objetiva (Government of India, 2005).

Na cidade de Madrid, na Espanha, o Programa Municipal de Gestão da Demanda da Água define que programas de auditorias de água trazem não só o compromisso dos órgãos públicos na aplicação de medidas para reduzir o consumo de água, mas servem para desenvolver uma política interna do uso eficiente da água. Essa política inclui tanto a formação de pessoal quanto um acompanhamento sistemático para avaliar diariamente os ganhos alcançados em economia de água (Ayuntamiento de Madrid, 2005).

Para o governo australiano, a gestão da conservação de água em edifícios, conforme o Quadro 22, é dividida em seis áreas-chave - Key Result Areas (KRAs): planejamento, liderança, consciência, medição, processo e abastecimento (Australian Government, 2006).

Uma série de medidas de eficiência hídrica, de comportamento e/ou relacionadas com a gestão é possível para cada KRA. No entanto, é necessário que essas medidas sejam aplicadas de acordo com um Plano de Gestão da Água - Water Management Plan. O governo 
australiano entende que este plano faça parte de um amplo Sistema de Gestão Ambiental Environmental Management System - desenvolvido de acordo com a ISO 14001.

Quadro 22 - Detalhamento das áreas-chave (Key Result Areas) dos planos de gestão de água na Austrália

\begin{tabular}{|c|l|}
\hline Áreas & \multicolumn{1}{c|}{ Informações / Medidas } \\
\hline Planejamento & $\begin{array}{l}\text { Estrutura política e funcional das organizações; princípios a serem adotados; metas a serem } \\
\text { alcançadas; estratégias a serem seguidas; planos de gestão. }\end{array}$ \\
\hline Liderança & $\begin{array}{l}\text { Gestão existente; papéis e responsabilidades de cada ator envolvido; prestação periódica de } \\
\text { contas; necessidade de revisões de gestão e execução de ações. }\end{array}$ \\
\hline Consciência & $\begin{array}{l}\text { Motivação dos usuários; planejamento de ações educacionais; definição de indicadores de } \\
\text { desempenho em treinamento; inovação; efetiva participação. }\end{array}$ \\
\hline Medição & $\begin{array}{l}\text { Métodos de medição; coleta de dados, compilação e análise; aferição; relatórios de } \\
\text { desempenho. }\end{array}$ \\
\hline Processo & $\begin{array}{l}\text { Práticas de gestão; métodos operacionais e de trabalho; normas e diretrizes; procedimentos; } \\
\text { oportunidades de parcerias; aprovações e financiamentos. }\end{array}$ \\
\hline Abastecimento & $\begin{array}{l}\text { Custos; informações sobre as tarifas; confiabilidade; qualidade; fornecimento de dados; } \\
\text { gestão da necessidade de assistência. }\end{array}$ \\
\hline
\end{tabular}

Fonte: Australian Government (2006)

$\mathrm{Na}$ Espanha, em algumas comunidades autônomas, a legislação determina que todo edifício industrial, comercial ou de serviços, cujo consumo de água seja igual ou superior a 10.000 m³/ano, deve ter um plano de gestão sustentável da água (Ayuntamiento de Madrid, 2005).

Tais planos devem conter dados sobre os usos finais de água, identificação de áreas passíveis de redução, reciclagem ou reutilização de água ou aproveitamento de águas pluviais, bem como as medidas de eficiência a serem aplicadas, os objetivos do plano de conservação e o cronograma das ações planejadas. O plano tem uma validade máxima de quatro anos e deve sofrer revisão bienal, contendo as medidas aplicadas na utilização eficiente da água e seu nível de cumprimento.

No caso dos Estados Unidos, há um consenso nos estados de que um programa bem-sucedido de gestão ambiental na área de eficiência hídrica deve começar com um Plano de Eficiência da Água. No estado da Carolina do Norte, é recomendado que o plano seja executado seguindo os passos listados no Quadro 23.

Segundo informações do Departamento de Energia dos Estados Unidos, o aumento da eficiência hídrica em prédios administrativos federais nos Estados Unidos passa por um plano de gestão integral da água, que inclui informações claras sobre o uso desde o ponto de acesso ou de geração até a disposição final ou reutilização. Nesse caso, o plano deve incluir, além dos dados básicos de uso de água, medição e instalações sanitárias dos edifícios, informações acerca de regulamentos e requisitos federais de uso da água em edifícios públicos (US Department of Energy, 2010). 
Quadro 23 - Passos de um Plano de Eficiência da Água na Carolina do Norte (EUA)

\begin{tabular}{|c|l|}
\hline Passo & \multicolumn{1}{c|}{ Características } \\
\hline $\begin{array}{c}\text { Definição de compromissos e } \\
\text { metas }\end{array}$ & $\begin{array}{l}\text { As metas de eficiência de água podem ser quantitativas ou qualitativas e os } \\
\text { compromissos iniciais devem explorar oportunidades de uso eficiente da água, } \\
\text { com definição de metas iniciais. }\end{array}$ \\
\hline $\begin{array}{c}\text { Apoio contínuo e } \\
\text { disponibilidade de recursos }\end{array}$ & $\begin{array}{l}\text { Designação de um gerente de conservação, que deve, entre outras ações: } \\
\text { coordenar a execução da auditoria de água; estabelecer critérios de execução } \\
\text { para as medidas de eficiência da água e desenvolver um plano de ação. }\end{array}$ \\
\hline $\begin{array}{c}\text { Realização de auditoria de } \\
\text { água para estimar usos finais } \\
\text { da água e custos envolvidos }\end{array}$ & $\begin{array}{l}\text { A auditoria de usos finais da água é feita com auxílio de um diagrama de } \\
\text { equilíbrio da água, que identifica todos os usos da água de sua fonte, por meio } \\
\text { de identificação dos processos no próprio local. }\end{array}$ \\
\hline $\begin{array}{c}\text { Gestão da água } \\
\text { Preparação de plano de ação } \\
\text { e cronograma de implantação }\end{array}$ & $\begin{array}{l}\text { Abordagens gerais para identificar oportunidades de economia de água em } \\
\text { instalações e equipamentos, tais como: identificar usos desnecessários e } \\
\text { corrigir vazamentos; definir quantidades mínimas de água para realizar tarefas; } \\
\text { reutilizar sequencialmente a água, após o tratamento de água já utilizada. }\end{array}$ \\
\hline $\begin{array}{l}\text { Desenvolvimento de um plano de ação que especifique e liste todas as medidas } \\
\text { pe eficiência hídrica propostas, resultante da auditoria, incluindo, por exemplo: } \\
\text { da quantidade de água a ser economizada e prazos a serem atingidos; medidas } \\
\text { de eficiência identificadas durante a auditoria da água; avaliação financeira de } \\
\text { cada medida; necessidade de alterações de projetos de engenharia. }\end{array}$ \\
\hline $\begin{array}{c}\text { Acompanhamento de } \\
\text { resultados e divulgação de } \\
\text { dados de sucesso }\end{array}$ & $\begin{array}{l}\text { Promove boas relações com os usuários, com a comunidade e com outras } \\
\text { empresas. São exemplos de ações: emissão de boletins informativos e } \\
\text { brochuras; divulgação de notícias na mídia local; participação em seminários e } \\
\text { comitês de conservação da água; divulgação de resultados. }\end{array}$ \\
\hline
\end{tabular}

Fonte: Adaptado de North Carolina Department of Environment and Natural Resources (2009)

Cabe exemplificar que, em 2000, foram definidas nos EUA boas práticas de gestão - Best Managment Practices (BMP), de acordo com Brave \& Tanner (2002), cujo objetivo principal era o desenvolvimento de um plano de gestão de água comum às agências públicas federais americanas. Os planos tinham prazo de cinco anos para sua conclusão e de dez anos para que as agências federais completassem pelo menos quatro das dez BMPs em $80 \%$ de suas instalações. Também era obrigatória uma revisão bienal da eficácia desse gerenciamento. Essa meta condicionava o repasse de recursos federais a esses órgãos.

\subsubsection{Auditoria e usos finais de água}

Em todas as nações pesquisadas, entre os passos metodológicos dos planos de conservação ou de gerenciamento de água, existe uma fase importante: a auditoria de água. Os principais componentes de uma auditoria de água são: coleta de dados e tendências de consumo de água; classificação das fontes, principais áreas de uso e procedimentos a serem realizados; detecção de vazamentos e desperdício; identificação de oportunidades de economia de água e o desenvolvimento de estratégias realistas (ANA et al., 2005).

Segundo o Australian National Audit Office (2012), o método mais preciso para a aferição do consumo de água na Austrália usa o National Australian Built Environment Rating System (NABERS). Ele pode ser determinado por meio de uma auditoria de eficiência hídrica, que 
deve ser realizada por um profissional devidamente qualificado, no prazo de dois a quatro anos. As auditorias devem registrar o desempenho atual do edifício e identificar opções para potenciais economias no consumo de água.

De acordo com o governo australiano, essas auditorias não tem um padrão pré-estabelecido, mas uma auditoria básica deve incluir uma inspeção de equipamentos e sistemas, apresentação do estado da arte das tecnologias aplicadas à gestão do consumo de água, recomendação de indicadores de desempenho, comparação com os indicadores padrão do mercado (como o NABERS) e identificação de viabilidade de implantação de soluções, com cálculo de retorno de investimentos (Australian Government, 2006).

De uma equipe de auditoria da água devem participar um especialista em eficiência de água, profissionais familiarizados com operações de manutenção e possíveis auditores externos. Os documentos necessários para a auditoria são, entre outros: informações e registros de contas de água (ano anterior completo); projetos e legislação completos dos sistemas; número de usuários por categoria e número de turnos de trabalho e de limpeza. (North Carolina Department of Environment and Natural Resources, 2009). Na Colômbia, a auditoria de água em edifícios, de acordo com Martínez (2012), segue as etapas descritas no Quadro 24.

Quadro 24 - Etapas de uma auditoria de água na Colômbia

\begin{tabular}{|c|l|}
\hline Fase da auditoria & \multicolumn{1}{c|}{ Dados considerados } \\
\hline \multirow{5}{*}{ Preparação } & $\begin{array}{l}\text { a) localização, idade e extensão das instalações; b) quantificação de dados de ocupação, } \\
\text { refeições servidas, água utilizada por produto produzido e por pessoa; c) funcionamento } \\
\text { da instalação e número de empregados em cada turno de manutenção; d) consumo total } \\
\text { de água e consumo de água por unidade de produto por mês, nos últimos três anos; e) } \\
\text { faturas de água e de tratamento de águas residuárias de, pelo menos, dois anos; f) } \\
\text { listagem dos equipamentos consumidores de água, incluindo as respectivas vazões; g) } \\
\text { inventário de equipamentos economizadores de água, se houver; e h) usos finais da } \\
\text { água, fornecidos em mª incluindo os requisitos de medição e calibração. }\end{array}$ \\
\hline \multirow{5}{*}{ Condução } & $\begin{array}{l}\text { a) horários de funcionamento dos equipamentos; b) vazões e requisitos de qualidade da } \\
\text { água exigidos para cada utilização; c) quantidade e qualidade de água necessária para o } \\
\text { funcionamento adequado dos equipamentos; d) periodicidade adequada para a medição } \\
\text { do consumo; e e) balanço hídrico da organização, com sugestão de medidas de controle } \\
\text { e verificação, no caso de haver diferenças maiores que 10\%. }\end{array}$ \\
\hline \multirow{2}{*}{ Relatório } & $\begin{array}{l}\text { a) síntese das recomendações, quantificação das economias, custos de investimento e } \\
\text { respectivos períodos de retorno; b) descrição das instalações; c) consumo histórico; d) } \\
\text { saldos de água; e e) opções de eficiência, análise técnica e cálculos de economia. }\end{array}$ \\
\hline
\end{tabular}

Fonte: Martínez (2012)

As recomendações para auditoria em edifícios na Índia sugerem o prazo de um ano para o levantamento de dados, bem como a verificação de vazões em equipamentos com uso de recipientes com tamanho sabido, por período de tempo de um minuto, e a constante verificação dos hidrômetros (Government of India, 2005). Seus componentes-chave e indicadores sugeridos em auditorias de água estão detalhados no Quadro 25. 
Quadro 25 - Componentes-chave e indicadores sugeridos em auditorias de água na Índia

\begin{tabular}{|c|l|}
\hline Componente & \multicolumn{1}{c|}{ Características } \\
\hline $\begin{array}{c}\text { Informações pré- } \\
\text { auditoria }\end{array}$ & $\begin{array}{l}\text { Compreensão da natureza dos usos da água e sistemas instalados no edifício. } \\
\text { Discussão com os usuários, funcionários de limpeza e de cozinha no que concerne os } \\
\text { vários usos da água durante o dia, suas fontes, quantidade de suprimentos, medição de } \\
\text { origem, distribuição, armazenamento e geração de efluentes. }\end{array}$ \\
\hline \multirow{2}{*}{ Referências } & $\begin{array}{l}\text { Coleta de dados primários e secundários para várias utilizações de água identificadas, } \\
\text { com uso de questionário de preenchimento individual, registrados ao longo de um } \\
\text { período variável de tempo, sendo considerada representativa uma amostra de 20\% do } \\
\text { número de usuários. Pode ser coletado também o número de visitantes sobre um } \\
\text { período de 10 dias, juntamente com o seu tempo de permanência. }\end{array}$ \\
\hline $\begin{array}{c}\text { Realização de uma } \\
\text { auditoria de água no } \\
\text { nível do edifício }\end{array}$ & $\begin{array}{l}\text { Coleta de dados e processamento para uso pessoal, incluindo água potável, uso de } \\
\text { vasos sanitários, lavagem das mãos, limpeza do edifício, irrigação, lavagem de } \\
\text { utensílios de cozinha feitos com base no consumo real. Para a estimativa das vazões } \\
\text { utilizam-se frascos de 1 litro e baldes de 10 litros. Para registros do número de usos } \\
\text { diários em vasos sanitários e mictórios, assim como a frequência diária de uso das } \\
\text { torneiras, sugere-se um prazo de uma semana de observação pela equipe de auditoria. }\end{array}$ \\
\hline
\end{tabular}

Fonte: Government of India (2011) - adaptado

\subsubsection{Vazamentos e setorização da medição}

Segundo o governo australiano, a demanda em edifícios públicos concentra-se especialmente em vazamentos (10-30\%), sistemas de condicionamento de ar (30\%), irrigação (1-20\%) e sistemas sanitários (30-40\%). No caso dos vazamentos, os casos mais comuns ocorrem com picos de pressões de serviço e em torres de resfriamento, torneiras, mictórios, válvulas ou mecanismos de descargas de vasos sanitários, mangueiras de incêndio, tubos enterrados e válvulas de controle de pressão (Australian Government, 2006).

Algumas ações são indicadas para o combate aos desperdícios em vazamentos, tais como: a) verificações rotineiras em dias e horários em que os prédios estejam vazios; b) instalação provisória de data-loggers para identificação rápida e precisa de vazamentos; c) setorização de medidores em edifícios novos; d) orientação aos prestadores de serviços de manutenção e limpeza sobre a corresponsabilidade no monitoramento dos vazamentos; e e) instalação de adesivos nos locais de maior incidência de vazamentos, encorajando os usuários a contatar os gerentes de manutenção predial.

No estado norte-americano da Califórnia (1994) é recomendado fazer inspeções e vistorias de rotina nos equipamentos e sistemas hidráulicos dos edifícios, durante o horário de trabalho, para localizar tubos quebrados, vazamentos e mangueiras defeituosas. É salutar também incentivar os funcionários a denunciarem aos responsáveis pela manutenção todos os vazamentos e o mau funcionamento dos equipamentos sanitários. Em todos os casos, o reparo deverá ser realizado prontamente. 
O consumo de água em edifícios públicos e comerciais na Austrália é tipicamente determinado por leituras dos medidores feitas por prestadores de serviço público que, no Brasil, são chamados de concessionárias de serviços públicos. Na maioria dos casos em que a medição individualizada não está disponível, esses dados representam a base para controlar o consumo (ANAO - Australian National Audit Office, 2012).

O mesmo autor recomenda que, para qualquer edifício com o uso sazonal de água (como torres de resfriamento ou irrigação), haja monitoramento do consumo ao longo de um ano inteiro, devido à tendência de aumento de taxas de vazamentos ao longo do tempo.

Um único medidor geral é normalmente insuficiente. Conforme orienta o governo australiano, medidores parciais (ou sub-medidores) devem ser instalados nos locais considerados viáveis para controle do uso final e em áreas do edifício que representem mais que $20 \%$ do consumo total (Australian Government, 2006).

No Canadá, reconhecendo que os edifícios comerciais frequentemente têm consumo significativo de água em praças de alimentação e cozinhas, recomenda-se que essas atividades de consumo devem ser contabilizadas separadamente, com a instalação de hidrometração individual (Building Owners and Managers Association of Canada, 2013).

\subsubsection{Indicadores}

Uma vez que o consumo padrão tenha sido estabelecido, é intensamente recomendada pela literatura internacional a definição de indicadores específicos para medir o desempenho. Os indicadores de desempenho permitem a caracterização objetiva do uso da água em relação às atividades específicas das organizações, fornecendo uma medida mais precisa da eficiência da água consumida e uma base de comparação desse desempenho em relação a outros edifícios.

Não obstante a necessidade de se definir indicadores de referência para qualificar o nível de desempenho de edifícios, é fundamental que se verifique a representatividade destes, bem como a disponibilidade de se obter essa base de dados. Segundo a literatura pesquisada, também parece evidente que o clima do local, o uso de refrigeração e a sensibilidade dos usuários em relação ao atingimento de metas de consumo são importantes para a definição dos parâmetros escolhidos nos países com indicadores consolidados.

O Quadro 26 define parâmetros de desempenho comuns para o consumo de água em alguns países pesquisados. Percebe-se que há casos em que a variável área (total ou de escritórios) é entendida como mais representativa que o número de usuários. A morfologia básica de um 
pavimento de um prédio público administrativo contém: a) circulações horizontais e verticais; b) conjuntos de sanitários, copas e depósitos; c) áreas técnicas de instalações; e d) áreas de escritórios. Nesta pesquisa, as áreas totais e de escritórios serão consideradas no estudo de caso para fins de comparação.

Quadro 26 - Parâmetros de desempenho no consumo de água para edifícios públicos e comerciais em alguns países

\begin{tabular}{|c|c|c|}
\hline País & Parâmetros de desempenho & Unidade \\
\hline \multirow{6}{*}{ Austrália } & Consumo de água por área de escritórios & $\begin{array}{l}\mathrm{m}^{3} / \mathrm{m}^{2} \text { área } \\
\text { escritórios/ano }\end{array}$ \\
\hline & Consumo de água por área edificada & $\mathrm{m}^{3} / \mathrm{m}^{2}$ área total/ano \\
\hline & $\begin{array}{l}\text { Consumo de água por área edificada com ou sem } \\
\text { condicionamento de ar }\end{array}$ & $\mathrm{m}^{3} / \mathrm{m}^{2}$ área total/ano \\
\hline & Consumo total de água & $\mathrm{m}^{3} / \mathrm{ano}$ \\
\hline & Consumo por pessoa & $\mathrm{m}^{3} /$ pessoa \\
\hline & Selo NABERS & 1 a 6 estrelas \\
\hline \multirow{2}{*}{ Canadá } & Consumo de água por área edificada & $\mathrm{m}^{3} / \mathrm{m}^{2}$ área total/ano \\
\hline & Consumo de água com condicionamento de ar & $\mathrm{m}^{3} /$ ano \\
\hline \multirow{6}{*}{ EUA } & Consumo total de água na edificação & galões/ano $^{12}$ \\
\hline & Consumo total de água com irrigação & galões/ano \\
\hline & Consumo total de água com condicionamento de ar & galões/ano \\
\hline & Consumo por pessoa & galões/pessoa \\
\hline & Consumo por número de refeições em restaurantes & galões/refeição \\
\hline & Consumo por número de assentos em restaurantes & galões/assento/dia \\
\hline \multirow[t]{2}{*}{ Inglaterra } & Consumo de água por área edificada & $\begin{array}{c}\text { litros } / \mathrm{m}^{2} \text { área } \\
\text { total } / \mathrm{dia}^{13} \text { ou ano }\end{array}$ \\
\hline & Consumo de água por empregados & litros/empregados/dia \\
\hline ova Zelândia & Consumo de água por área edificada & $\mathrm{m}^{3} / \mathrm{m}^{2}$ área total $/ \mathrm{ano}$ \\
\hline
\end{tabular}

Fontes: Australian Government (2006), BOMA Canada (2013); Real Property Association of Canada (2011); Dziegielewski et. al. (2000); Waggett \& Arotsky (2006). Bint et al. (2005)

Cabe destacar que a conformação da tipologia edilícia estudada pode contribuir para a tomada de decisão do parâmetro a ser usado. Se for evidente, por exemplo, na amostra estudada, a presença de edifícios que apresentem configurações com áreas comuns desproporcionais, como no caso de museus e bibliotecas, a área de escritórios tende a ser um parâmetro menos eficiente. No estudo de caso desta pesquisa também serão incluídos indicadores de áreas de cobertura e áreas molhadas apenas como uma contribuição a futuros estudos de representatividade de parâmetros para a escolha de indicadores confiáveis.

No que concerne à área condicionada desses edifícios, cabe pesquisar previamente a representatividade do consumo de água desses sistemas no consumo total dos edifícios. O mesmo entendimento pode ser estendido às áreas ajardinadas. Se a amostra tem edifícios com áreas irrigadas extensas, seu parâmetro de consumo deve considerar essa variável. A definição

\footnotetext{
${ }^{12}$ Um galão americano equivale a 3,785 litros.

${ }^{13} \mathrm{Na}$ bibliografia consultada, um ano comercial com 253 dias.
} 
desse tipo de parâmetro sempre pressupõe uma análise apurada da sua amostra. O pesquisador sempre deverá se ater a características marcantes da tipologia estudada. No caso do estudo de caso desta pesquisa, também serão levantados indicadores relativos a áreas ajardinadas.

$\mathrm{Na}$ Austrália, os consumos de água em edifícios públicos e de escritórios podem ser comparados também entre si usando o sistema NABERS, um sistema nacional de classificação ambiental voluntária. Existe nele uma classificação que mede o desempenho operacional de edifícios públicos e de escritórios com base em diversas variáveis, incluindo o consumo de água (Australian Government, 2006).

O desempenho dos edifícios é classificado em uma escala que varia de uma a seis estrelas, em que uma estrela é atribuída a edifícios de baixo desempenho e seis estrelas indicam os casos excepcionalmente bons de desempenho. A média do mercado australiano, de acordo com o Australian National Audit Office (2012), fica entre 2,5 e 3 estrelas. As referências de consumo das principais cidades australianas estão mostradas na Tabela 3.

Tabela 3 - Indicadores de consumo de água para edifícios das seis principais cidades da Austrália $\left(\mathrm{m}^{3} / \mathrm{m}^{2} / \mathrm{ano}\right)$

\begin{tabular}{|c|c|c|c|c|c|c|}
\hline Classificação & Sydney & Melbourne & Canberra & Adelaide & Brisbane & Perth \\
\hline 1 estrela & 1,73 & 1,03 & 0,99 & 1,08 & 2,53 & 1,41 \\
\hline 2 estrelas & 1,39 & 0,86 & 0,83 & 0,90 & 1,99 & 1,14 \\
\hline 2,5 estrelas & 1,21 & 0,77 & 0,75 & 0,80 & 1,72 & 1,01 \\
\hline 3 estrelas & 1,04 & 0,69 & 0,67 & 0,71 & 1,44 & 0,88 \\
\hline 3,5 estrelas & 0,87 & 0,60 & 0,59 & 0,62 & 1,17 & 0,75 \\
\hline 4 estrelas & 0,70 & 0,53 & 0,51 & 0,53 & 0,90 & 0,61 \\
\hline 4,5 estrelas & 0,52 & 0,43 & 0,43 & 0,44 & 0,62 & 0,48 \\
\hline 5 estrelas & 0,35 & 0,35 & 0,35 & 0,35 & 0,35 & 0,35 \\
\hline 6 estrelas & 0,175 & 0,175 & 0,175 & 0,175 & 0,175 & 0,175 \\
\hline
\end{tabular}

Fonte: Australian Government (2006)

O governo australiano explica que o diferencial desse sistema em relação a outros métodos de benchmarking é que os seus dados foram projetados para cada clima em que o edifício está localizado, dado que os fatores climáticos são um dos principais determinantes do consumo de água associados aos serviços de construção. Essa inovação na definição de indicadores de consumo no Brasil pode perfeitamente seguir o modelo australiano no que tange ao zoneamento bioclimático.

Ainda segundo o governo australiano, o indicador mais representativo da gestão eficiente de água em edifícios de escritórios é a área de locação, que no Brasil é chamada de área útil ou privativa, cujas unidades de medida são litro/ $\mathrm{m}^{2} / \mathrm{ano}$ ou $\mathrm{m}^{3} / \mathrm{m}^{2} / \mathrm{ano}$. Outros indicadores recomendados são o desempenho do sistema de condicionamento ou a área condicionada, 
com unidades de medida de litro/ $\mathrm{m}^{2}$ de áreas com ar condicionado/ano e litros $/ \mathrm{m}^{2} /$ horas de funcionamento com ar condicionado das torres de refrigeração. O motivo da preferência pelo indicador supracitado é seu fator de correlação, pois o de área útil é muito superior $\left(\mathrm{r}^{2}=\right.$ 0,6899) ao de densidade de ocupação $\left(\mathrm{r}^{2}=0,0008\right)$ (Australian Government, 2006).

Um estudo de Bint et al. (2005) também recomenda que adotem a área útil como melhor indicador, todavia com fatores de correlação muito próximos $\left(\mathrm{r}^{2}=0,59\right.$ para densidade de ocupação e $\mathrm{r}^{2}=0,61$ para área útil). Esse estudo considera que os dados de ocupação são pouco confiáveis, posto que são repassados pelos gerentes prediais, enquanto que os dados de área útil são mais fáceis de comparar pelos registros dos edifícios existentes nas prefeituras.

Os dados dos edifícios públicos australianos indicam a média de desempenho de 3.400 litros $/ \mathrm{m}^{2} /$ ano e a meta para os praticantes de boa gestão de água é de 2.000 litros $/ \mathrm{m}^{2} / \mathrm{ano}$.

Como visto, a padronização de indicadores é recomendada para países e regiões com características climáticas semelhantes. No caso do Canadá, país de clima predominantemente frio, os usos finais são fortemente concentrados no condicionamento de ambientes (como o aquecimento), conforme discrimina a Tabela 4 (Real Property Association of Canada, 2011).

De acordo com os índices de uso de água em edifícios públicos nos EUA, um funcionário típico, em uma instalação típica, utiliza 55 litros de água por dia. Portanto, um prédio público de escritórios com aproximadamente 200 funcionários usa cerca de 11.000 litros/dia de água, dos quais 4.650 litros/dia (42\%) para uso sanitário e de limpeza, 3.000 litros/dia (26\%) para refrigeração e/ou aquecimento, 2.200 litros/dia (20\%) para irrigação e 1.350 litros/dia (12\%) para outras necessidades de água (U.S. Department of Energy, 2010).

Tabela 4 - Distribuição típica de uso de água em edifícios públicos e comerciais no Canadá em 2009

\begin{tabular}{|c|c|c|}
\hline Tipo de Uso & Distribuição típica (\%) & Intervalo (\%) \\
\hline Refrigeração e aquecimento & 40 & $25 / 65$ \\
\hline Uso sanitário & 32 & $20 / 45$ \\
\hline Irrigação & 20 & $10 / 30$ \\
\hline Copas, cozinhas e restaurantes & 7 & $1 / 12$ \\
\hline Outros & 1 & $0,5 / 2$ \\
\hline
\end{tabular}

Fonte: Real Property Association of Canada (2011)

Nesse contexto, uma lei importante a ser citada é a Ordem Executiva 13514 (2009), do governo norte-americano, editada em 5/10/2009, que exigiu que todos os prédios públicos federais reduzissem seu consumo de água a uma taxa de $2 \%$ ao ano, desde o ano de 2007 , tendo como meta final o ano de 2020, conforme se visualiza no Gráfico 1. 
Gráfico 1 - Consumo de água em edifícios públicos federais dos EUA (galões/dia)

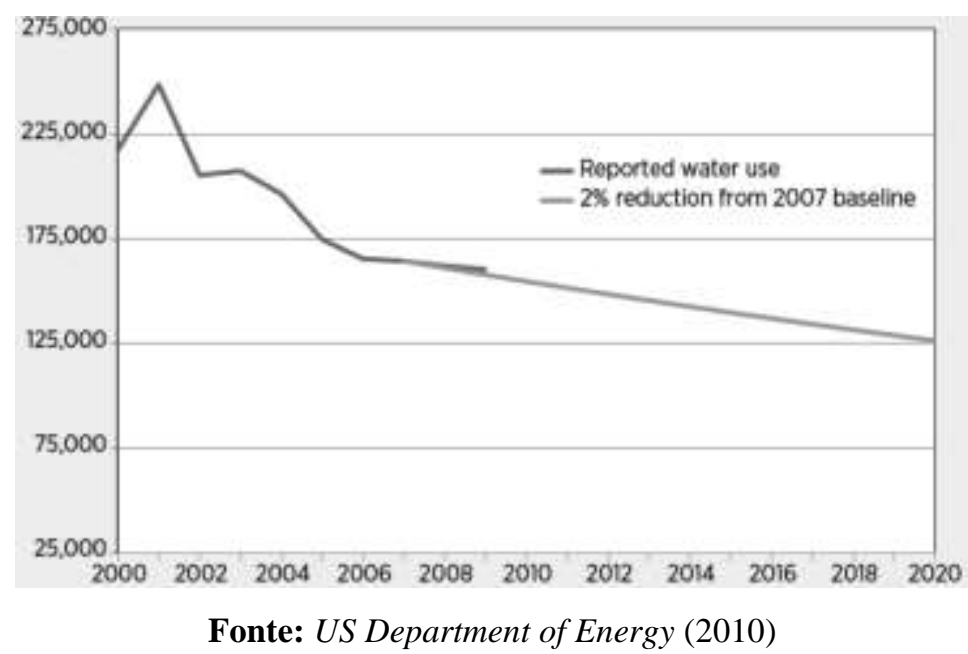

Em 2007, o consumo de água em edifícios públicos e comerciais no Canadá foi de 2.033 litros/m²/ano. Há perspectivas de que, em 2030, esse número caia para 712 litros $/ \mathrm{m}^{2} / a n o$, presumindo que a eficiência da conservação melhore ao longo do tempo. No entanto, se o consumo continuar no ritmo atual, estima-se que seu uso vai atingir 2.348 litros $/ \mathrm{m}^{2} /$ ano até 2030 (Sustainable Development Technology Canada, 2007).

A análise indicou também que, embora tenha havido uma tendência de usar índices baseados em ocupação (litros/pessoa), o indicador mais adequado para edifícios públicos ou comerciais de escritórios deveria se basear na área líquida de escritórios. Na mesma pesquisa, o intervalo de consumo ficou entre 129 litros/m²/ano e 538 litros/m²/ano (Real Property Association of Canada, 2011).

Tannuri \& Van Bellen (2014) explicam que indicadores do consumo de água são mais fáceis de serem compreendidos, por serem mais objetivos. Os autores informam também que, entre outros atributos, indicadores da área de sustentabilidade devem conter os de qualidade, como compreensibilidade, neutralidade, comparabilidade, materialidade e confiabilidade.

A maioria dos edifícios no chamado setor não residencial na Inglaterra, que inclui a administração pública e os edifícios comerciais, usa a água para ambientes sanitários, especialmente bacias e mictórios (70 a 95\% do uso). O uso da água nesses edifícios depende principalmente das suas áreas de escritórios. No caso inglês, conforme ilustra a Tabela 5, a Building Research Establishment (BRE) estabeleceu, em seu rótulo ambiental, níveis de desempenho e indicadores válidos também para os sistemas ou equipamentos sanitários dos edifícios. 
Tabela 5 - Níveis de desempenho eficiente de água para edifícios não residenciais no Reino Unido

\begin{tabular}{|c|c|c|c|c|c|c|c|}
\hline \multirow{2}{*}{ Tipo de Componente } & \multicolumn{6}{|c|}{ Indicadores de níveis de desempenho } & \multirow{2}{*}{ Parâmetro } \\
\hline & Base & 1 & 2 & 3 & 4 & 5 & \\
\hline Vasos sanitários & 6 & 5 & 4,50 & 4 & 3,75 & 3 & volume de descarga (litros) \\
\hline Torneira de lavatórios & 12 & 9 & 7,50 & 4,50 & 3,75 & 3 & litros/minuto \\
\hline Chuveiros & 14 & 10 & 8 & 6 & 4 & 3,50 & litros/minuto \\
\hline Mictórios & 7,50 & 6 & 3 & 1,50 & 0,75 & 0 & litros/unidade/hora \\
\hline $\begin{array}{c}\text { Sistemas de aproveitamento } \\
\text { de águas pluviais ou reúso } \\
\text { de águas cinzas }\end{array}$ & $0 \%$ & $0 \%$ & $0 \%$ & $25 \%$ & $50 \%$ & $75 \%$ & $\begin{array}{c}\text { \% da demanda usada em vasos } \\
\text { sanitários/mictórios com água } \\
\text { não potável reciclada }\end{array}$ \\
\hline Torneiras de copas & 12 & 10 & 7,50 & 5 & 5 & 5 & litros/minuto \\
\hline Torneiras de restaurante & 10,30 & 9 & 8,30 & 7,30 & 6,30 & 6 & litros/minuto \\
\hline Lava-louças doméstica & 17 & 13 & 13 & 12 & 11 & 10 & litros/ciclo \\
\hline Lava-louças industrial & 90 & 60 & 50 & 40 & 35 & 30 & litros/uso \\
\hline Lava-roupas industrial & 14 & 12 & 10 & 7,50 & 5 & 4,50 & litros $/ \mathrm{kg}$ \\
\hline
\end{tabular}

Fonte: BREEAM (2013)

No caso de restaurantes, os dados são mais escassos e em muitos casos referem-se a edifícios cuja função principal ou exclusiva é a de alimentação. Em edifícios públicos, as áreas para a alimentação podem não existir, serem destinadas apenas para lanches rápidos ou servirem pratos principais. Para se estabelecer uma relação de comparação com parâmetros internacionais é necessário que se considerem apenas os edifícios públicos que possuem uma estrutura edificada que serve pratos principais ao longo do horário laboral. Nesse caso também devem ser ponderados ou até desconsiderados casos em que se servem todas as refeições do dia, como restaurantes universitários.

Essa delimitação de função decorre do fato de os indicadores de consumo de água encontrados na literatura para restaurantes reportarem-se basicamente a três variáveis: número de refeições servidas, número de assentos disponíveis e a área total edificada. O número de refeições é mais preciso, pois não considera o período de funcionamento do edifício.

O número de assentos disponíveis pode ser considerado uma variável importante, mas pode sofrer distorções se comparado com locais com intervalos de funcionamento muito distintos, como um restaurante que serve desde café da manhã até o jantar comparado a outro que foca seus serviços apenas no horário de almoço.

Por fim, a área total edificada também pode ser considerada, mas não necessariamente poderia ser confiável, se comparados dados de locais com grande rotatividade de público e horários de atendimento diferenciados. Basta comparar restaurantes que servem pelo sistema à la carte e os que dispõem do sistema self-service. Há uma diferença muito grande de consumo entre esses dois sistemas. Os dados encontrados estão consolidados na Tabela 6. 
Tabela 6 - Indicadores nacionais e internacionais de consumo de água em restaurantes

\begin{tabular}{|c|c|c|}
\hline Local & Indicador & Parâmetro \\
\hline AWWA (Estados Unidos) & 6 a $9(22,7$ a 34$)$ & galões/refeição/dia (litros/refeição/dia) \\
\hline AWWA (Colorado) & $16,1(60,9)$ & galões/refeição/dia (litros/refeição/dia) \\
\hline SABESP & 20 a 30 & litros/refeição/dia \\
\hline AWWA (Estados Unidos) & 20 a 31 $(75,7$ a 117,3$)$ & galões/assento/dia (litros/assento/dia) \\
\hline AWWA (Colorado) & 10,58 a $14,31(40$ a 54,1) & galões/assento/dia (litros/assento/dia) \\
\hline AWWA (Estados Unidos) & 130 a 331 $(0,5$ a 1,25$)$ & galões $/ \mathrm{m}^{2} / \mathrm{ano}\left(\mathrm{m}^{3} / \mathrm{m}^{2} / \mathrm{ano}\right)$ \\
\hline Austrália (existente) & 8,4 & $\mathrm{~m}^{3} / \mathrm{m}^{2} / \mathrm{ano}$ \\
\hline Austrália (meta) & 6,36 & $\mathrm{~m}^{3} / \mathrm{m}^{2} / \mathrm{ano}$ \\
\hline
\end{tabular}

Fontes: Waggett \& Arotsky (2006); Dziegielewski (2000); Fyfe et al. (2012), SABESP (2010)

Em alguns países há metas de redução de consumo de água mais acentuadas, notadamente devido ao estresse hídrico existente, com o consumo crescendo mais rápido que a disponibilidade de recursos hídricos.

Tal situação ocorre em países europeus, Austrália e Estados Unidos. Países como o Brasil, que tem historicamente uma grande oferta desse insumo, quando definem programas com redução de indicadores de consumo de água, muitas vezes acabam optando por metas mais brandas, especialmente devido à resistência de todos os setores da sociedade envolvidos, desde a concessionária ao usuário final. Tal situação decorre da manutenção da cultura do desperdício e da falta de investimentos e de planejamento públicos em infraestrutura e em campanhas de sensibilização da população.

Em resumo, nota-se a predominância do uso do indicador de área $\left(\mathrm{m}^{2}\right)$ nos EUA e Europa e do indicador de número de consumidores no Brasil. Nesta pesquisa não foram encontrados dados de outros países semelhantes aos indicadores brasileiros, com exceção dos indicadores relativos a restaurantes, com relativa semelhança com os padrões americanos.

A Tabela 7 resume todos os indicadores internacionais levantados nesta pesquisa. Os valores distintos de cada país refletem a cultura do uso e a oferta disponível em cada nação. É importante frisar que as metas traçadas refletem a situação de oferta e de necessidade de redução de consumo de água de cada nação.

Um indicador médio das fontes encontradas gira em torno de 800 litros $/ \mathrm{m}^{2}$ áreas escritórios/ano ou 380 litros $/ \mathrm{m}^{2}$ área total/ano. Se considerarmos o parâmetro mais utilizado no Brasil e as referências consideradas nesta pesquisa, o indicador médio é de 10.000 litros/pessoa/ano ou cerca de 840 litros/pessoa/dia. 
Tabela 7 - Comparação de indicadores internacionais de consumo de água em edifícios comerciais e públicos

\begin{tabular}{|c|c|c|c|}
\hline Local & $\begin{array}{c}\text { Indicador } \\
\text { litros/m² área } \\
\text { escritórios/ano }\end{array}$ & $\begin{array}{c}\text { Indicador } \\
\text { litros } / \mathbf{m}^{2} \text { área } \\
\text { total/ano } \\
\end{array}$ & $\begin{array}{c}\text { Indicador } \\
\text { litros/pessoa } \\
\text { /ano } \\
\end{array}$ \\
\hline Best Practice Range (Canadá) & 129 a 538 & & \\
\hline NABERS (Austrália) - 1 estrela & 1.500 & & \\
\hline NABERS (Austrália) - 2 estrelas & 1.250 & & \\
\hline NABERS (Austrália) - 3 estrelas & 1.000 & & \\
\hline NABERS (Austrália) - 4 estrelas & 750 & & \\
\hline NABERS (Austrália) - 5 estrelas & 500 & & \\
\hline NABERS (Austrália) - Edifícios Públicos (Existente) & 3.340 & & \\
\hline NABERS (Austrália) - Edifícios Públicos (Meta) & 2.000 & & \\
\hline BOMA Best (Canadá) & 680 & & \\
\hline Edifícios comerciais (Canadá) & 2.033 & & \\
\hline Edifícios comerciais - meta (Canadá) & 712 & & \\
\hline Auckland (Nova Zelândia) & 760 & & \\
\hline Wellington (Nova Zelândia - existente) & 1.030 & & \\
\hline Wellington (Nova Zelândia - meta) & 720 & & \\
\hline Estados Unidos (Dziegielewski et. al., 2000) & 1.590 & & \\
\hline Brasil (SABESP, 2001) - edifícios comerciais e públicos & $900^{14}$ & & $11.250^{14}$ \\
\hline UK Watermark - Inglaterra (existente) & & 520 & 9.300 \\
\hline UK Watermark - Inglaterra (meta) & & 221 & 6.400 \\
\hline $\begin{array}{c}\text { Interoperability Solutions for European Public } \\
\text { Administration - ISA (meta Bélgica) }\end{array}$ & & 160 & \\
\hline ISA (meta Alemanha) & & 660 & \\
\hline ISA (meta Europa) & & 300 & \\
\hline AWWA (Estados Unidos) & & 200 & 6.400 \\
\hline CIRIA (Inglaterra) & & 600 & 4.000 \\
\hline Brasil (Sant'Ana, 2013) - edifício público & & & 10.800 \\
\hline Brasil (Kammers e Ghisi, 2006) - edifícios públicos & & & $\begin{array}{l}6.300 \mathrm{a} \\
9.000^{15}\end{array}$ \\
\hline Brasil (Proença e Ghisi, 2009) - edifícios comerciais & & & $\begin{array}{c}6.750 \mathrm{a} \\
14.625^{15} \\
\end{array}$ \\
\hline
\end{tabular}

Fontes: Bannister, Munzinger \& Bloomfield (2005); Bint et al. (2005); Bint et al. (2014); BOMA Canada (2013); Dziegielewski et. al. (2000); Kammers \& Ghisi (2006); Kitchen, Rooney \& Whitehouse (2003); Proença \& Ghisi (2009); SABESP (2001); Sant'Ana (2013); Sustainable Development Technology Canada (2007); Waggett \& Arotsky (2006)

\subsection{Síntese analítica do capítulo 3}

O objetivo do capítulo 3 foi o de detalhar as recomendações elencadas em ANA et al. (2005) e no MMA (2014), bem como comparar suas metodologias apresentadas com a prática internacional.

Inicialmente cabe levantar se a sequência de ações sugerida nas publicações acima é adequada à realidade da gestão de edifícios públicos. O primeiro questionamento que se faz, conforme as matrizes de ações do Quadro 19 (p. 103), diz respeito à medição do consumo de água e seu

\footnotetext{
${ }^{14}$ Este valor corresponde ao valor original ajustado, considerando todos os dias do ano e não somente os dias úteis, de forma a viabilizar a comparação com as outras fontes pesquisadas. Foram considerados dias úteis de segunda-feira a sexta-feira, no total de 260 dias/ano.

${ }^{15}$ Foi considerada, nos outros exemplos do Brasil, a média de 225 dias/ano (255 dias úteis - 30 dias de férias, atestados médicos, casamento, falecimento de cônjuges, alistamento militar, doação de sangue, nascimento de filhos, eleições).
} 
monitoramento. A medição setorizada é estimulada, mas também entendida como de difícil implantação em alguns casos.

No caso dos edifícios públicos, a justificativa do controle de consumo é o que deve ser considerado para um eventual ajuste do sistema hidrossanitário. A disposição da tubulação de distribuição também deverá ser verificada. Se a parte vertical do sistema é distribuída por meio de passagens acessíveis, como shafts e poços de ventilação, a viabilidade de hidrometração setorizada é facilitada. Tais fatores serão fundamentais para o convencimento dos gestores públicos na reserva de recursos públicos para tal fim.

Independentemente se há medição setorizada no edifício público, a auditoria do consumo de água deve ser estimulada para a adoção de estratégias de redução desse consumo. Cabe esclarecer que, no caso do estudo de caso desenvolvido nesta pesquisa e detalhado no próximo capítulo, as ações iniciais de auditoria recomendadas pela literatura foram seguidas. As observações acerca das especificidades dos órgãos públicos no que tange aos passos recomendados pela bibliografia consultada são as seguintes:

- Análise do consumo histórico - Por se tratar de dado de fácil verificação, essa análise deverá ser feita por técnico da área de manutenção ou da área de engenharia do órgão, com picos de consumo e respectivas causas de variação identificadas. A visualização desses dados pode ser feita em gráficos, para facilitar a leitura. O responsável por analisar os dados deve ser amplo conhecedor das rotinas de manutenção predial, visto que podem haver distorções que não refletem uma tendência de aumento relativo de consumo de água, mas sim um aumento de população, problemas de fornecimento da concessionária, vazamentos não aparentes ou instalação de equipamentos novos;

- Levantamento do edifício e usuários - Esse levantamento é pré-requisito para o passo do cálculo de indicadores. Nessa fase devem ser levantados dados sobre o número de usuários, áreas edificadas, usos finais de água de cada tipologia de peça sanitária (vasos sanitários, lavatórios, mictórios, chuveiros, duchas higiênicas, pias de cozinha, tanques, filtros), procedimentos de limpeza e irrigação de jardins, entre outros. Nesse instante, é recomendada a exclusão de peças com desregulagem evidente ou com quantitativos irrisórios;

- Cálculo do indicador de consumo - As recomendações de ANA et al. (2005) afirmam que a variável mais representativa para qualquer tipo de edificação são os agentes consumidores. Este capítulo demonstra que outras variáveis são amplamente utilizadas em 
âmbito internacional. Esta pesquisa recomenda, para este passo, o levantamento de outros indicadores para edifícios públicos administrativos. Indicadores com uso de variáveis de áreas totais e de escritórios possuem suficiente respaldo científico e podem ser comparados com os dados de outros países. Também se reveste de muita importância o levantamento de áreas ajardinadas, quando for o caso. Em caso de existência de restaurantes, as variáveis de número de refeições servidas e número de assentos disponíveis devem ser igualmente levantadas.

Depois de concluída essa fase, há que se montar um diagnóstico de consumo, de forma abrangente, no qual se destaquem os locais de maior demanda, os indicadores encontrados comparados aos disponíveis no mercado, preferencialmente para a mesma tipologia de edificação. Também devem ser descritos, se detectados, comportamentos diferenciados de usuários no consumo de água ou presença de vazamentos, bem como os resultados específicos para consumos de restaurantes, limpeza e irrigação.

No plano de intervenção, a publicação de ANA et al. (2005) é bastante precisa e objetiva. A sugestão inicial é a de se verificar a viabilidade técnica e econômica de possíveis ações, baseando-se nos dados do diagnóstico. Como o fator econômico é relevante nos edifícios públicos, é fundamental que ocorra uma pesquisa técnica de preços de mercado. Após isso, recomendam-se ações com foco na gestão de consumo da água para os pontos críticos do edifício. O planejamento temporal das ações também deve ser cuidadosamente definido, de forma que haja tempo do engajamento e sensibilização dos usuários.

Como forma de se verificar a aderência das recomendações técnicas da publicação de ANA et al. (2005) e MMA (2014) ao cenário internacional de conservação de água, também foi levantado neste capítulo o estado da arte acerca do uso de PCAs em outros países. Nesta análise, pode-se afirmar que a Austrália e os Estados Unidos foram os países que mais se destacaram quanto ao volume e detalhamento de dados. A Austrália possui um documento nacional (Australian Government, 2006), enquanto a orientação do governo norte-americano é mais descentralizada.

Canadá, Inglaterra e Espanha têm uma literatura bem organizada, mas com informações ainda relativamente genéricas. Já a Índia não tem a cultura da conservação de água arraigada na população, apesar de seu grave problema de estresse hídrico, talvez pela pouca penetração dos programas de governo em um território tão densamente povoado. A Colômbia, assim como o 
Brasil, ainda carece de instrumentos governamentais que estipulem regras mais rígidas, de caráter compulsório quanto à conservação de água em edifícios públicos e comerciais.

Os planos de conservação de água são semelhantes em sua essência, mas com detalhes diferenciadores, como um enfoque maior da literatura norte-americana no que tange ao custo das ações de eficiência hídrica. O Canadá aparenta maior preocupação com as ações educativas e o governo espanhol atua de forma mais impositiva. No caso de edifícios públicos, os Estados Unidos determinam, inclusive, sanções orçamentárias a gestores públicos em caso de descumprimento de metas. Os prazos para a montagem desses planos variam de dois a quatro anos e há previsão de revisões periódicas variando de um a dois anos.

Como recomendação desta pesquisa, assim como alguns estados brasileiros, como São Paulo e Minas Gerais, aplicam sanções por uso excessivo de água, entende-se que os legisladores deveriam impor uma redução mínima de consumo anual aos gestores públicos ou a implantação de sistemas que reduzam a pressão sobre o sistema público de abastecimento. Em contrapartida, os órgãos que atingissem determinada meta de redução poderiam receber bonificações como reduções de tarifas, por exemplo. Também devem ser determinados prazos máximos de montagem desses planos e a periodicidade de suas revisões.

No que tange aos vazamentos de água, há preocupação maior dos governos indiano e australiano, devido a grandes perdas em seus sistemas e edifícios. No aspecto da hidrometração setorizada ou individualizada, a maioria dos países aprova essa ação, com ênfase nos usos de condicionamento de ar, irrigação e sistemas sanitários dos edifícios, como forma de auxílio no gerenciamento da demanda.

No que concerne às auditorias de água, os passos metodológicos internacionais são similares, com destaque para a aferição do consumo de água com uso do rótulo ambiental NABERS na Austrália. Tais rótulos podem ser um referencial de uso de indicadores, com metas mínimas de desempenho, levando gestores a uma atuação proativa e participativa na economia de água. A exigência da etiqueta Procel Edificações na categoria "A" em todas as vertentes, conforme IN 2/2014 - SLTI/MOPG, já foi um avanço nesse sentido no Brasil em relação aos edifícios públicos. Uma lacuna importante identificada foi a inexistência de indicadores nacionais consolidados de consumo de água em edifícios públicos, com setorização de dados pelo critério bioclimático, semelhante ao modelo australiano, para que sirva de instrumento de incentivo a gestores públicos na adoção de estratégias de conservação desse insumo. 
Pelos dados coletados, observou-se que há uma grande amplitude de valores referenciais, mostrando que os indicadores devem ser regionalizados e devem considerar aspectos bioclimáticos, culturais, de ocupação e tipologia edilícia. A diferença no âmbito internacional é que o indicador mais utilizado é o litro/m²/ano, enquanto que no Brasil é o litro/pessoa/dia.

A vantagem do uso do litro/m²/ano como parâmetro de comparação está na gama de referências mundiais e na facilidade de levantamento de dados nas concessionárias. Alguns dos países pesquisados indicam explicitamente que o melhor indicador é a área de escritórios em vez da ocupação (Real Property Association of Canada, 2011; North Carolina Department of Environment and Natural Resources, 2009).

Por outro lado, deve se considerar que há imprecisão dos dados desta área útil, visto que a definição das áreas das edificações abre espaço para muitas interpretações dos profissionais que as calculam, gerando conclusões que não refletem a realidade. Como exemplo, basta imaginar o uso dos mesmos indicadores para edificações públicas com fins administrativos comparadas a outras que estocam mercadorias. Nesse caso, pode haver discrepâncias que provocam a divulgação de informações distorcidas. Em caso de programas de governo ou na adoção de rótulos ambientais, tais distorções podem desqualificar dados simplesmente para o atingimento de metas estabelecidas, comprometendo a eficiência hídrica buscada. As considerações de cálculo de área útil do estudo de caso desta pesquisa estão descritas nos capítulos seguintes.

O parâmetro litros/pessoa/dia traz uma variável igualmente objetiva, mas com a mesma possibilidade de imprecisão da alternativa anterior, posto que os aspectos de ausências eventuais de usuários e de presença de populações flutuantes podem interferir nos resultados. Para combater tais discrepâncias, é recomendado que, em caso de apresentação de dados para o registro de indicadores de consumo de água, cada órgão entregue, além dos dados de consumo mensal, relatório técnico que detalhe a metodologia de cálculo das áreas edificadas, bem como informe a população daquele órgão para a determinação do indicador.

Pelo que foi exposto, percebe-se que há espaço para avanço na aplicação das orientações brasileiras, dependendo de fatores como clima, disponibilidade de dados, tecnologia utilizada, participação dos usuários, comprometimento de agentes políticos, idade dos edifícios e viabilidade técnico-operacional para implantação de melhorias. 


\section{CAPÍTULO 4 - METODOLOGIA}

A metodologia foi estruturada considerando os objetivos traçados para a pesquisa proposta, com vistas a avançar em relação às técnicas de gestão em prédios públicos administrativos no Distrito Federal. Na Figura 11 apresenta-se a estrutura da metodologia utilizada no desenvolvimento da pesquisa.

Figura 11 - Estrutura da metodologia proposta

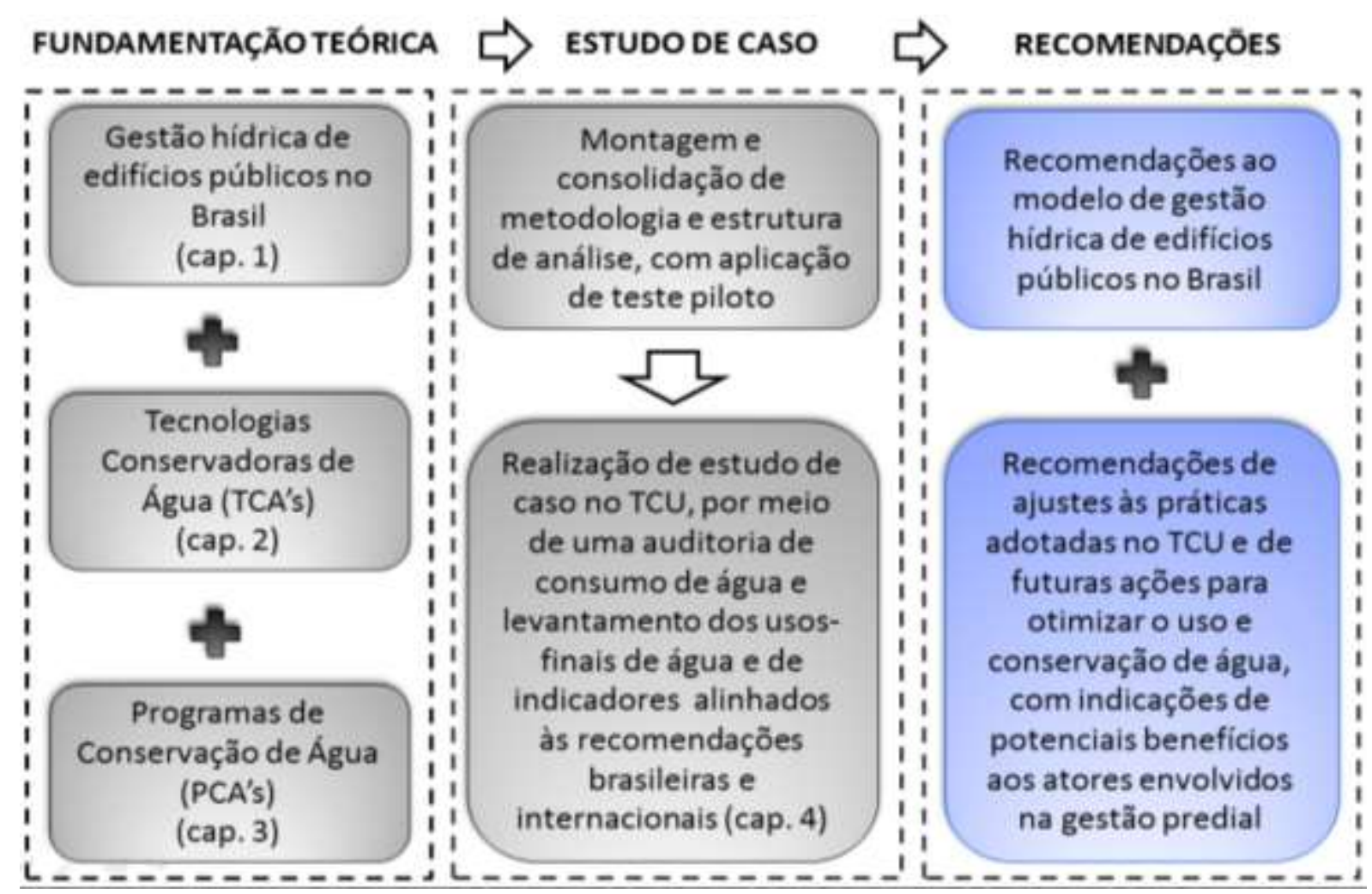

Desta forma, para se obter os resultados esperados, foram cumpridos os seguintes passos metodológicos:

- Levantamento de referencial teórico relativo à gestão predial hídrica de edifícios públicos, focando especialmente:

Na situação dos recursos hídricos no Brasil;

$\checkmark$ Na legislação aplicável à área de gestão e eficiência hídrica em escala urbana e as pertinentes aos edifícios públicos;

$\checkmark$ Nos planos e programas de conservação de água aplicáveis aos edifícios públicos, destacando casos relevantes no Brasil e no mundo;

$\checkmark$ Nas tecnologias e sistemas mais utilizados na atualidade na conservação de água em edifícios. 
- Montagem e consolidação de estrutura de análise, com aplicação de teste piloto, para validação das ferramentas das entrevistas estruturadas e aplicação no estudo de caso;

- Realização de estudo de caso no Tribunal de Contas da União (TCU), por meio de uma auditoria de consumo e de levantamento dos usos finais de água e de indicadores alinhados às recomendações brasileiras e internacionais, resultando em diagnóstico da gestão predial hídrica neste órgão e proposição de plano de intervenção;

- Proposição de recomendações ao modelo de gestão hídrica de edifícios públicos no Brasil;

- Proposição de recomendações de ajustes às práticas adotadas no TCU, destacando benfeitorias e sistemas que contribuem para a conservação da água, bem como futuras ações para incentivar o uso racional e o não potável de água, com indicações de potenciais benefícios aos atores envolvidos na gestão predial.

Uma vez concluída a revisão bibliográfica e consolidação da fundamentação teórica da pesquisa, fez-se necessária a revisão da metodologia e a definição dos próximos passos. $\mathrm{O}$ primeiro passo foi a montagem de todo o planejamento das entrevistas estruturadas, após a finalização da pesquisa de referencial teórico, desenvolvimento de questionários e levantamento de dados iniciais do TCU.

O Tribunal de Contas da União foi escolhido devido à facilidade de coleta de dados, à população significativa de usuários (3.750 pessoas) e pela utilização apenas parcial de TCAs, fato que ajudou na realização de um estudo mais completo. O complexo arquitetônico do TCU, cuja função é executada de forma primordialmente administrativa, representa um modelo de conjunto federal edificado na região central de Brasília/DF, que se caracteriza pela grande concentração de edifícios públicos em seu território.

Após a conclusão deste primeiro passo, foram aplicados os testes pilotos, com número reduzido de usuários, para verificar a coerência, a legibilidade e a clareza das perguntas, o tempo médio de execução e a reação natural dos respondentes. Os resultados obtidos neste primeiro passo levaram ao ajuste de alguns pontos dos questionários, como, por exemplo, um maior destaque ao foco institucional da pesquisa, pois, para alguns usuários não ficou claro se as perguntas se referiam ao órgão público ou às suas residências.

Com a realização dos testes pilotos, foi estruturada a auditoria do consumo de água, com ajuste das entrevistas estruturadas (demonstradas nos Anexos 1 a 6) e levantamento de todos os dados do TCU, tomando como base as ações sugeridas por ANA et al. (2005) e MMA (2014) e as práticas, ações, conceitos e recomendações internacionais, ampliando os 
benefícios que um PCA pode trazer ao edifício público, tanto em relação ao investimento de tecnologias quanto a mudanças de postura de gestão predial.

Foram obtidos dados de importância estratégica para a caracterização da utilização de água no TCU, suficientes para destacar aspectos relevantes da ocupação nos terrenos, áreas construídas, áreas de ambientes com uso de água (áreas molhadas) e consumo separados por tipologia (higiene, limpeza, irrigação, equipamentos, entre outros).

\subsection{Coleta de dados}

Entre os métodos precisos para se obter dados confiáveis de usos finais em um edifício, de uma maneira geral, cita-se a utilização de medidores de vazão. Os mais conhecidos são os hidrômetros, que oferecem leituras presenciais ou remotas, conforme já descrito no item 2.1. No caso de pesquisa para usos finais, que necessitam de leitura específica em cada aparelho que utiliza água, a tecnologia remota dos data loggers é a mais utilizada atualmente.

Esses sistemas permitem captar e armazenar os dados nos horários determinados pelo operador e transmitir os dados remotamente para um coletor instalado, por exemplo, em uma central de manutenção. A grande barreira para a aplicação deste método foi o custo dos equipamentos, que possuem tecnologia mais avançada, bem como a autorização formal do TCU para tal compra. Sua utilização mostrou-se inviável, portanto, para esta pesquisa.

Foto 3 - Exemplo de data logger de vazão e pressão
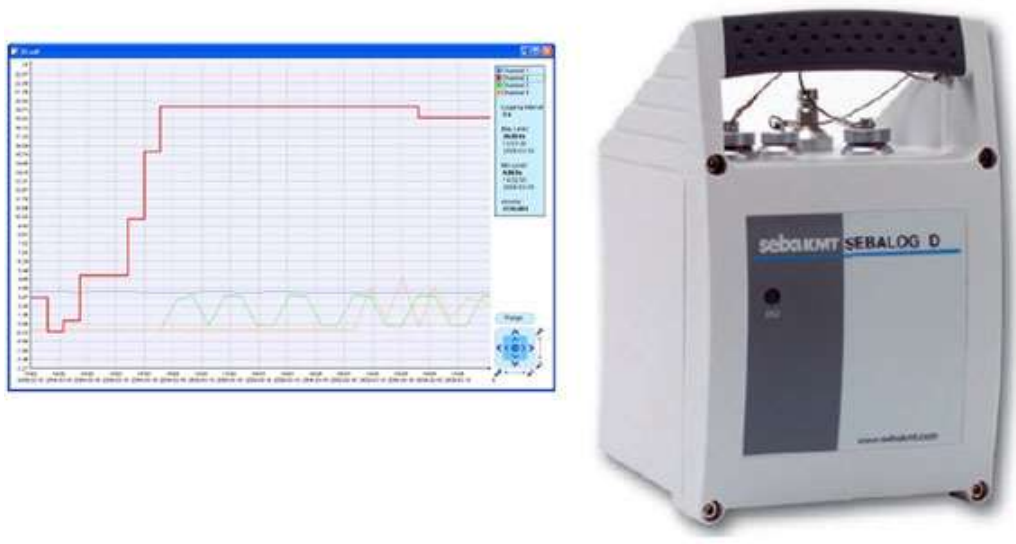

Fonte: sondeq.com.br

Por outro lado, para se chegar a dados representativos, apesar de menos precisos, a solução passa pelo levantamento in loco do histórico de contas de água cobrados pela concessionária local, bem como por meio de entrevista direta com os usuários, na qual os servidores do órgão pesquisado respondem a um questionário objetivo, com respostas de múltipla escolha. Essa metodologia busca investigar os hábitos dos usuários permanentes do prédio em relação ao 
uso da água, como para necessidades fisiológicas, higiene pessoal, limpeza de utensílios, irrigação de jardins e lavagem de veículos. É recomendável que se desenvolvam questionários gerais e alguns específicos, para os responsáveis por determinados setores, a depender do uso e conhecimento sobre o tema, conforme o Quadro 27. Na presente pesquisa os questionários utilizados estão exemplificados nos Anexos 1 a 6.

Quadro 27 - Perfis dos usuários de edifícios públicos e características das questões abordadas em auditorias de água

\begin{tabular}{|c|c|c|}
\hline Usuário & Características do usuário & $\begin{array}{c}\text { Características das questões abordadas } \\
\text { em auditorias de água }\end{array}$ \\
\hline Administrativo & $\begin{array}{l}\text { Usuários comuns dos prédios, que } \\
\text { basicamente utilizam a água para } \\
\text { necessidades pessoais e para a } \\
\text { dessedentação. }\end{array}$ & $\begin{array}{l}\text { Usos finais dos aparelhos, estimativa } \\
\text { (empírica) de vazão ou quantidade de } \\
\text { acionamentos no momento do uso, } \\
\text { conhecimento de tecnologias conservadoras } \\
\text { de água, tipos de tecnologias ou } \\
\text { equipamentos já implantados no seu local } \\
\text { de trabalho, tempo decorrido médio na } \\
\text { utilização de determinados equipamentos. }\end{array}$ \\
\hline $\begin{array}{l}\text { Limpeza e } \\
\text { copeiragem }\end{array}$ & $\begin{array}{l}\text { Funcionários terceirizados da área de } \\
\text { limpeza e/ou responsáveis por setor que } \\
\text { gerencia o(s) contrato(s) das áreas de } \\
\text { limpeza e copeiragem do edifício } \\
\text { estudado. }\end{array}$ & $\begin{array}{l}\text { Usos finais específicos de limpeza de pisos, } \\
\text { paredes, divisórias e forros; procedimentos } \\
\text { e equipamentos utilizados; uso de copas; } \\
\text { frequência de uso de pias de copas, } \\
\text { eletrodomésticos que eventualmente } \\
\text { utilizam água; uso e frequência de lavagem } \\
\text { de carros; estimativa (empírica) de } \\
\text { consumo. }\end{array}$ \\
\hline Manutenção & $\begin{array}{l}\text { Funcionários terceirizados da área de } \\
\text { manutenção predial, preferencialmente } \\
\text { bombeiros hidráulicos e/ou responsáveis } \\
\text { por setor que gerencia o(s) contrato(s) } \\
\text { da área de manutenção predial do } \\
\text { edifício estudado. }\end{array}$ & $\begin{array}{l}\text { Usos finais específicos de manutenção } \\
\text { predial, notadamente nas áreas } \\
\text { hidrossanitárias, de ar condicionado (se for } \\
\text { o caso) e de irrigação de jardins. Frequência } \\
\text { de ocorrência de chamados de manutenção, } \\
\text { detecção de vazamentos, manutenção } \\
\text { preventiva. }\end{array}$ \\
\hline
\end{tabular}

Como forma de minimizar algum tipo de constrangimento e para que o usuário não se sinta invadido em sua privacidade, o questionário deve adotar critérios objetivos, mas que mesclem com certo empirismo, visto que uma pessoa leiga não conhece, por exemplo, vazões de água de determinadas louças sanitárias.

Cabe também levantar se o usuário externo do edifício típico administrativo tem um uso representativo no seu consumo de água. A depender da função do edifício e do tempo de permanência desses indivíduos, a resposta é positiva. Proença e Ghisi (2009) levantaram em edifícios comerciais um consumo estimado de 4,5\% do volume de água relativo à população flutuante. Entretanto, se o atendimento ao público é rápido ${ }^{16}$ ou essa parcela de usuários é pouco representativa em função do público interno, assume-se que a parcela deve ser

\footnotetext{
${ }^{16}$ No Distrito Federal as empresas são obrigadas a prestar o atendimento no prazo máximo de trinta minutos, conforme o art. $4^{\circ}$ da Lei Distrital no 2.529 , de 21/02/2000.
} 
desconsiderada. No caso do TCU, como detalhado mais adiante, a população flutuante foi considerada relevante.

Na mesma linha, é possível manter pesquisadores de plantão nos pontos de consumo de água, durante alguns dias, para monitoramento em tempo real dos usos finais de água. Essa possibilidade foi descartada nesta pesquisa por ter sido considerada muito invasiva e constrangedora aos usuários.

Com os dados das entrevistas, é possível, a depender de sua representatividade, estabelecer indicadores de uso de cada tipo de peça sanitária, bem como determinar suas vazões ponderadas, considerando os modelos existentes e as informações prestadas pelos fabricantes. É possível também compará-los aos dados de outros edifícios públicos, utilizando variáveis como área de construção, área irrigada, área de superfícies molhadas e o consumo médio anual de água, bem como a população em si.

O foco principal deste trabalho de definição de usos finais foi a utilização dos equipamentos e sistemas que utilizam água no conjunto edificado do TCU. O uso no restaurante, na limpeza e na irrigação também foi considerado.

Foram englobados na categoria de limpeza, para efeito dessa metodologia, os tanques de limpeza, as torneiras de limpeza não usadas na irrigação e os aparelhos eletrodomésticos que eventualmente necessitem de água, como filtros, cafeteiras, refrigeradores e máquinas de lavar roupas ou louças. Também se sugere o tratamento em separado de dados relativos às centrais de água gelada do sistema de ar condicionado, visto que sua média de consumo de água é de fácil obtenção, baseada em informações da equipe de manutenção ou dados dos fabricantes.

O método, portanto, para se obter essa informação nesta pesquisa foi o uso de entrevistas diretas e de malas diretas (mensagens em meio eletrônico institucional), com identificação dos usuários apenas em caso de entrevistas específicas de gestores. Para que se pudessem obter dados precisos, as perguntas trataram do uso das peças sanitárias, às quais, em alguns casos, pressupõe-se o uso íntimo e individual, como é o caso do vaso sanitário e da ducha higiênica. Nesse caso, foi necessário que o assunto tratado, de certa forma, invadisse a intimidade e a privacidade das pessoas, fazendo com que houvesse uma resistência natural à participação ou a marcação de respostas que não condizem com a realidade. 
A mala direta tem um alcance bem representativo, mas deve, necessariamente, ter mecanismos que preservem a identidade dos usuários. A programação de informática desenvolvida e o cuidado com os textos inseridos garantem esse anonimato e podem ajudar a aumentar o número de participantes. Como não há mecanismos para torná-la obrigatória, a pesquisa tende a ter pouca participação, dado que o assunto não tem implicação direta no dia a dia dos usuários.

As dificuldades encontradas nesse tipo de abordagem são as barreiras impostas pelos próprios órgãos para acesso a e-mails institucionais e a necessidade de um apoio de pessoal interno na consolidação dos dados.

As entrevistas diretas são mais eficientes quando realizadas com pessoal especializado, que presta as informações em caráter técnico, como no caso dos profissionais ligados à manutenção predial e limpeza, no qual uma entrevista com o responsável pelo setor foi suficiente. Outra possibilidade é o preenchimento dos campos do questionário pelo próprio pesquisador, com dados levantados por observação de hábitos, como no caso da cozinha de um restaurante.

No presente estudo de caso, foi divulgada a pesquisa de usos finais com envio de avisos objetivos aos e-mails institucionais de todos os usuários do TCU, preferencialmente sendo remetidos por coordenadores de setores responsáveis por toda a parte administrativa do edifício.

No Anexo 1 desta pesquisa é apresentado o modelo que foi utilizado para a aplicação direta aos usuários do TCU, com respostas objetivas e que puderam ser tabuladas e quantificadas com facilidade. De acordo com o teste piloto realizado no TCU, o tempo médio de resposta deste modelo foi de três a cinco minutos.

Apenas como exemplo, são apresentados, nos Anexos 2 a 6 desta pesquisa, modelos de questionários que podem ser aplicados em qualquer órgão público, como ocorreu no estudo de caso desta pesquisa, com perguntas simples, objetivas e que produzem um resultado preciso quanto à caracterização dos usos finais de água nos edifícios. No Anexo 2 há um questionário específico para os responsáveis do restaurante ou lanchonete do órgão público.

No Anexo 3 apresenta-se um modelo de documento que pode ser aplicado diretamente aos responsáveis pelo setor de manutenção predial, preferencialmente com a pessoa que detém maior conhecimento sobre a rotina de manutenção das instalações hidrossanitárias e de ar 
condicionado. No caso de impossibilidade de entrevista direta, também pode ser enviado para resposta remota. Os Anexos 4 e 5 são destinados aos responsáveis pelas áreas de limpeza e jardinagem, respectivamente, cujos consumos são de vital importância para o diagnóstico final do edifício. O Anexo 6 destina-se aos especificadores técnicos e projetistas do órgão.

No que tange ao método de cálculo de vazões como de ponderações acerca dos usos finais, foram definidas equações que estão descritas mais adiante, nos detalhamentos destes procedimentos.

Espera-se que, com a implantação da metodologia proposta no TCU, possa ser estabelecido futuramente um modelo para a aplicação de Programas de Conservação de Água (PCAs) em outros edifícios públicos. Como são métodos práticos, há a necessidade de coleta desses dados de forma mais objetiva e diretamente com o usuário ou com pessoas-chave na instituição.

\subsection{Procedimentos}

A seguir serão detalhados os procedimentos realizados nos ambientes para a aferição dos dados da pesquisa.

\subsubsection{Sanitários e copas}

Para se calcular as vazões das torneiras, foi utilizado recipiente padrão de volume conhecido, com gradação a cada 250 mililitros, e cronômetro digital. A Foto 4 ilustra os passos da aferição da vazão das torneiras dos banheiros.

O procedimento, como ilustra a Foto 4, consistia basicamente em:

- No caso de torneiras de acionamento hidromecânico (sanitários), pressionava-se até o limite possível e imediatamente soltava-se o êmbolo. Foi cronometrado o tempo de liberação de água (em segundos) e o volume de água liberado (em litros), resultando assim em vazões dos pontos mapeados, utilizando-se a Equação 1;

$\mathbf{q}=\mathbf{V} / \mathbf{t}$

(Equação 1)

em que: $\quad$ q = Vazão do aparelho hidráulico (litros/segundo);

$\mathrm{V}=$ Volume de água liberado (litros); e

$\mathrm{t}=$ Tempo cronometrado de liberação de água pelo aparelho (segundos).

- No caso de torneiras com manípulo roscável (copas), girava-se o manípulo em um quarto 
de volta até que o volume de água atingisse um litro na gradação do recipiente coletor, quando a torneira era fechada. Foi cronometrado o tempo de liberação de água (em segundos). Como já havia um volume pré-definido, foram definidas em seguida as vazões dos pontos mapeados, também utilizando-se a Equação 1, considerando-se o volume como um litro.

Foto 4 - Recipiente padrão e procedimento para cálculo de vazão de água em torneiras
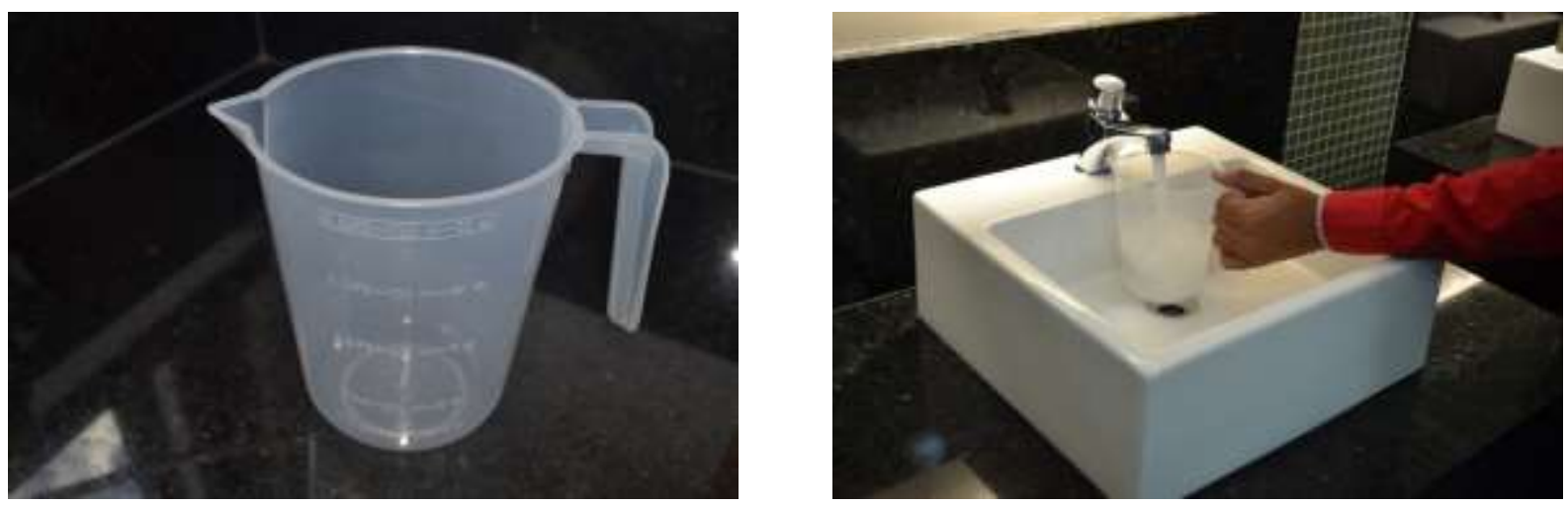

Fonte: TCU

Cabe salientar que o procedimento utilizado para cálculo da vazão das torneiras da copa foi utilizado para chuveiros e duchas higiênicas. Essas peças sanitárias, presentes em poucos locais do conjunto arquitetônico do TCU, tinham, assim como as torneiras, variações de pressão ao longo dos andares. Para cálculo do consumo auditado, foi utilizada a média aritmética dos levantamentos.

No caso dos mictórios, foi utilizado apenas o cronômetro digital para verificar regulagens anormais e definir o consumo médio. Como em todo o conjunto do TCU os mictórios possuem sensor de presença e são do mesmo fabricante, as vazões são pré-definidas.

Cabe esclarecer que, em relação às torneiras de limpeza existentes sob todas as bancadas dos lavatórios de todos os sanitários do TCU, não foram realizadas medições para cálculo de vazões, dado que, no caso do consumo efetuado pela equipe de limpeza desses ambientes, a unidade de medida foi a quantidade de baldes utilizados.

\subsubsection{Irrigação}

Os gastos de água foram calculados tomando por base o número de horas diárias em que os aspersores funcionam e a vazão das torneiras de abastecimento do sistema.

Também foi verificada a representatividade no consumo mensal da irrigação em cada edifício do conjunto arquitetônico do TCU. O cálculo tomou por base o consumo médio mensal de 
cada edifício ao longo do período em que foram disponibilizados os dados, bem como a estimativa do consumo da irrigação ao longo dos meses do ano, conforme mostrado na Tabela 16.

Tal estimativa foi definida por uma proporcionalidade inversa do índice pluviométrico médio ao longo do período medido, que afeta diretamente o consumo de água pela irrigação. Quanto mais chuva, menos irrigação.

O cálculo de consumo de ar condicionado considerou as mesmas variáveis climáticas, bem como os dados de consumo dos equipamentos instalados.

\subsection{Tabulação dos dados}

O primeiro passo metodológico para a aplicação da pesquisa estruturada foi a realização de um teste piloto em uma das edificações do conjunto edificado do TCU. Esse teste serviu para se levantar eventuais problemas, como necessidade de ampliação ou redução de perguntas, clareza dos questionamentos e das opções de respostas disponibilizadas, facilidade de compilação de dados e efetivo atingimento do resultado esperado.

No caso da presente pesquisa, houve dificuldades de compreensão da abrangência institucional da pesquisa e ausência de alguns equipamentos sanitários no edifício escolhido. Superados os problemas encontrados no teste piloto, a pesquisa definitiva foi realizada por meio de mensagens institucionais com atalhos (links) para acesso a uma pesquisa remota, em que eram compilados automaticamente os dados. O programa utilizado foi o Survey Monkey.

Cabe ressaltar que parte das respostas obtidas nesta pesquisa foi preenchida em questionários de papel, visto que grande parte da equipe terceirizada do TCU não tem acesso à rede interna de computadores, impossibilitando a participação remota. Nesse caso, a inserção dos dados no sistema foi manual e não automática. Foi estipulado, tanto para respostas eletrônicas quanto respostas em papel, um prazo máximo para que os usuários instados a participar da pesquisa respondessem os questionários. Todos os dados de uso dos respondentes foram tabelados e, caso a caso, calculados seus respectivos consumos. Tanto nas perguntas acerca do número de usos quanto nas que prestavam informações a respeito do tempo de uso em cada aparelho sanitário, foi estabelecida uma média ponderada dos usos, seguindo a Equação 2.

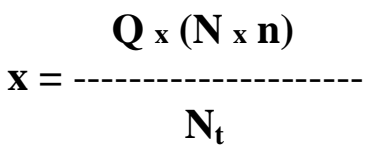

(Equação 2) 
em que: $\quad \mathrm{x}=$ média ponderada do número de usos de cada equipamento sanitário dos respondentes da pesquisa;

$\mathrm{Q}=$ quantidade de opções de respostas de cada pergunta;

$\mathrm{N}$ = número de respondentes de cada opção, dentre o número total de respondentes;

$\mathrm{n}$ = valor unitário de cada resposta, na unidade de medida definida no enunciado da pergunta; e

$\mathrm{N}_{\mathrm{t}}=$ número total de respondentes da pergunta.

A partir dos resultados das médias ponderadas, foram incorporadas as informações do consumo médio de água em cada utilização de cada peça sanitária. Tais valores são definidos pelos fabricantes, no caso dos vasos sanitários, ou levantados in loco, no caso de mictórios e torneiras de lavatórios, por meio das vazões das peças, em litros/segundo ou litros/minuto. Como estas últimas são peças em que o tempo de uso depende pouco do usuário e mais da regulagem do aparelho, foram considerados os tempos médios de regulagem das peças, mostrados nas Tabelas 15 e 16.

Quando se trata de chuveiros, torneiras de copas e duchas higiênicas, os dados levantados também necessitam das vazões das peças, também em litros/segundo, mas com a informação dos respondentes acerca do tempo de uso. Utilizando-se a Equação 1 (p. 135), em todos os casos, é possível identificar o consumo médio de água. Para se calcular o consumo médio diário estimado, basta seguir a Equação 3. É importante frisar que, neste momento, não foram ponderados os horários de trabalho dos participantes da pesquisa, mas na etapa seguinte.

$\mathrm{CD}_{\text {est }}=\mathbf{C}_{\text {uso }} \times \mathbf{N}_{\text {usos }}$

em que: $\quad \mathrm{CD}_{\mathrm{est}}=$ consumo médio diário estimado no TCU por tipo de peça sanitária, em litros/pessoa/dia;

$\mathrm{C}_{\mathrm{uso}}=$ consumo médio por uso, em litros; $\mathrm{e}$

$\mathrm{N}_{\text {usos }}=$ média ponderada do número de usos de cada peça sanitária.

De posse do consumo estimado diário, foi definido o consumo mensal estimado total de cada peça em todo o TCU, seguindo a Equação 4. Nesse caso, o número de dias de consumo ao longo do mês foi ponderado, a depender do tipo de usuário: autoridade/servidor, terceirizado, 
estagiário e visitante. As ponderações consideraram as devidas deduções de fins de semana, feriados e recesso de fim de ano. Ademais, foi considerado que:

- Parte dos terceirizados trabalham aos sábados (funcionários da limpeza e plantonistas da manutenção predial), e outra parte todos os dias (segurança);

- Parte dos servidores (comissionados) tem horários diferenciados;

- Os estagiários têm direito a recesso de 15 dias e trabalham em horário reduzido (4 horas);

- Existem, em média, ao menos 10 dias de feriados por ano que caem em dias de semana;

- Os visitantes utilizam, em média, 20\% do tempo de outros usuários.

$\mathrm{CM}_{\text {est }}=\frac{\left(\mathrm{Q}_{\mathrm{n}} \times \mathrm{D}_{\mathrm{n}}\right)}{-\mathrm{CD}_{\text {est }}}$

(Equação 4)

em que: $\quad \mathrm{CM}_{\mathrm{est}}=$ consumo médio diário estimado no TCU por tipo de peça sanitária, em litros/pessoa/dia;

$\mathrm{Q}_{\mathrm{n}}=$ quantidade de usuários para as " $\mathrm{n}$ " tipologias existentes: autoridades/servidores, terceirizados, estagiários e visitantes;

$\mathrm{D}_{\mathrm{n}}=$ número ponderado de dias no mês para as " $\mathrm{n}$ " tipologias existentes: autoridades/servidores, terceirizados, estagiários e visitantes; e

$\mathrm{CD}_{\text {est }}=$ consumo médio diário estimado no TCU por tipo de peça sanitária, em litros/pessoa/dia.

\subsection{Análises finais}

Para se obter as projeções definidas no item relativo às sugestões de ações para um futuro plano de intervenção no TCU, foram cruzados dados primários e considerado um cenário com a média dos consumos de água ao longo dos anos pesquisados.

A partir dos dados obtidos, foram definidos os usos finais de equipamentos e sistemas que utilizam água no TCU, comparando-se os dados com as pesquisas nacionais sobre o tema e a experiência internacional, subsidiando assim as análises apresentadas no Capítulo 5. 


\section{CAPÍTULO 5 - ESTUDO DE CASO}

As tecnologias conservadoras de água, para serem corretamente dimensionadas, precisam de dados precisos no que concerne à utilização dos pontos de água. Como citado anteriormente, os dados bibliográficos existentes acerca de usos finais em edifícios públicos são mínimos e ainda pouco representativos. É necessário, portanto, o avanço dos estudos de conservação de água que resultem em um retrato mais confiável: a) do desempenho dos sistemas de conservação de água existentes, e b) de dados de consumo de água pela população dos edifícios públicos.

O que se depreende das pesquisas já desenvolvidas sobre o tema é que há uma particularidade no consumo hidráulico dos edifícios públicos, dado que a própria morfologia, distribuição e quantificação dos ambientes que dispõem de instalações hidrossanitárias são suficientemente diferentes para abandonar a possibilidade de se adotarem dados de outras tipologias de edifício, como os residenciais ou industriais.

A única tipologia em que pode haver similaridade de funções com os edifícios públicos administrativos é a comercial de escritórios. Mesmo assim, há que se ponderar a tendência atual de incorporação de edifícios com sanitários em cada unidade comercial, fato que não se parece com o padrão de edifícios públicos.

Para que haja a gestão da demanda, é fundamental que se tenham todas as informações que envolvam o uso da água na edificação para o pleno conhecimento sobre a condição de utilização. O mapeamento dos usos da água na edificação deve ser feito por meio da análise do sistema hidráulico, dos processos de manutenção, do perfil de utilização da água pelos usuários e dos índices históricos de consumo.

\subsection{Auditoria do consumo}

Neste item, os passos recomendados por ANA et al. (2005) e MMA (2014), consolidados no Quadro 19 (p. 103), servem como orientação à análise dos resultados. Inicialmente são informados os dados do levantamento do consumo edificado. Após isso, é analisado o consumo histórico de água do conjunto edificado no TCU, bem como são descritas as informações que subsidiam o diagnóstico de consumo dos sistemas hidráulicos e serviços que utilizam água no TCU e que não dependem do usuário. Por fim, são resumidas as informações acerca do levantamento dos usos finais de água dos usuários e consequente cálculo dos índices de consumo, com destaque para cada edifício do conjunto arquitetônico do TCU. 


\subsubsection{Levantamento do conjunto edificado}

Conforme sugere a ANA et al. (2005), são descritas a seguir as características físicas e funcionais dos edifícios que compõem o conjunto arquitetônico do TCU.

O conjunto edificado do TCU em Brasília/DF fica localizado no Setor de Administração Federal Sul, região onde se concentram várias sedes de órgãos federais. A área do terreno estudado é de $73.800 \mathrm{~m}^{2}$ e abriga os seguintes edifícios:

- Edifício-Sede, também conhecido como Palácio Ruy Barbosa, com aproximadamente $21.900 \mathrm{~m}^{2}$ de área construída, onde são abrigados o Plenário do TCU, a Presidência da casa e algumas assessorias diretas, além de todos os gabinetes das autoridades do órgão. Possui um subsolo com mezaninos, pavimento térreo e três pavimentos-tipo;

- Anexos I, II e III, com aproximadamente $10.960 \mathrm{~m}^{2}, 13.330 \mathrm{~m}^{2}$ e $18.130 \mathrm{~m}^{2}$ de área construída, respectivamente, onde são abrigados os setores do TCU que desempenham atividades de auditoria e administrativas diversas. Os três anexos possuem um pavimento térreo e quatro pavimentos-tipo. Os Anexos I e II possuem um subsolo e o Anexo III possui três subsolos;

- Restaurante do TCU, com aproximadamente $2.080 \mathrm{~m}^{2}$ de área construída, destinado à alimentação dos servidores, terceirizados e estagiários, além do público externo. Essa edificação possui um pavimento principal, um mezanino em pavimento superior, uma cozinha industrial no $1^{\circ}$ subsolo e uma área de vestiários no $2^{\circ}$ subsolo.

Cabe esclarecer que, ao longo da projeção dos edifícios, há uma garagem subterrânea que se interliga e abriga cerca de 1.700 veículos. Essa garagem ocupa uma área aproximada de $46.930 \mathrm{~m}^{2}$.

O conjunto edificado está representado na planta de locação mostrada na Figura 12. A construção do Edifício-Sede foi finalizada em 1974. O projeto deste edifício é do arquiteto Renato Alvarenga. Esse edifício recebeu recentemente uma ampla reforma, finalizada em dezembro de 2014.

Os Anexos I e II, juntamente com o Restaurante, foram projetados com uma passarela de ligação e inaugurados em 1998. O Anexo III teve sua construção finalizada em 2011. O projeto desses edifícios foi do escritório de arquitetura Oscar Niemeyer. A Foto 5 mostra uma tomada aérea do conjunto edificado do TCU em Brasília/DF antes da construção do Anexo III (à esquerda), com destaque para o grande espelho d'água ao redor do Edifício Sede. A foto ao 
centro destaca os jardins e a passarela de interligação em primeiro plano. A foto da direita mostra o restaurante do TCU ao fundo.

Figura 12 - Planta de implantação dos edifícios no terreno do TCU em Brasília/DF

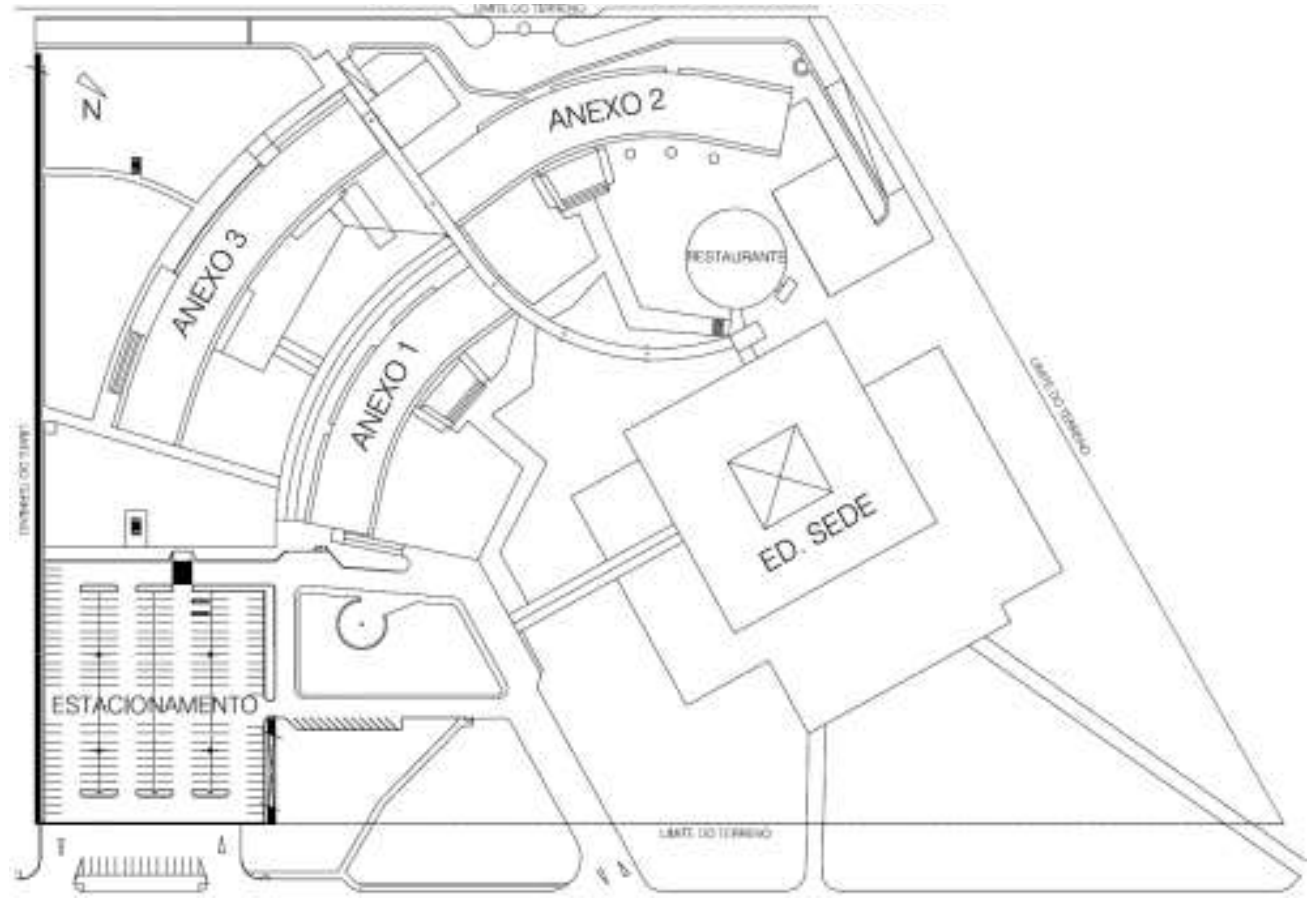

Fonte: TCU

Foto 5 - Vista aérea e parcial do conjunto edificado do TCU em Brasília/DF
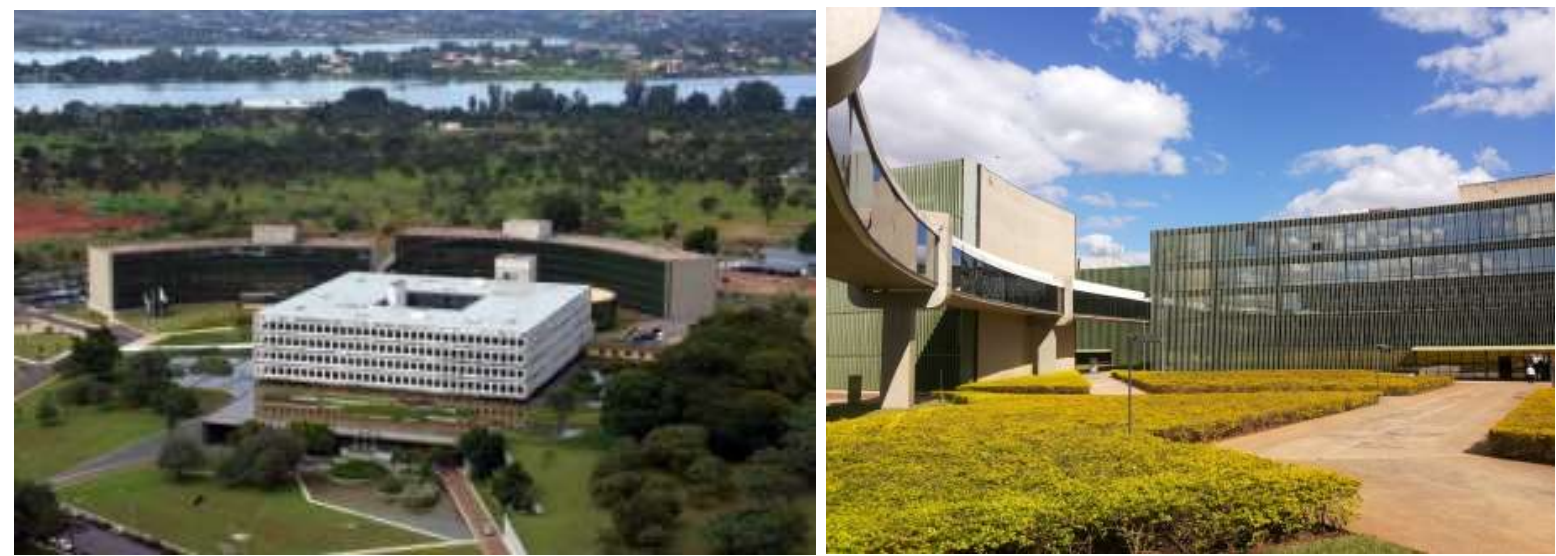

Fonte: TCU

O público que utiliza água no conjunto arquitetônico implantado resume-se às autoridades, servidores, terceirizados, estagiários e visitantes. As autoridades, para fins de quantitativos, serão incluídas na categoria de servidores. Os visitantes, por ser uma população flutuante, tem um impacto menor no uso de água potável no TCU. Segundo informações da área de segurança do TCU, a média de visitantes que entram nesse conjunto edificado é de 220 pessoas/dia. Somam-se a este total os usuários do restaurante provenientes dos órgãos 
públicos próximos ao TCU, que, segundo os administradores do restaurante do TCU, são, em média, cerca de 80 pessoas/dia.

A Tabela 8 resume a proporção de usuários dos edifícios, seguindo as categorias acima. Os visitantes passam, em média, $20 \%$ do tempo que os demais usuários utilizam, segundo informações estimativas dos setores que os recebem em número expressivo, como o protocolo e a sala de advogados. Como essa categoria, proporcionalmente, representa $8 \%$ do total de usuários, seu impacto no consumo de água potável foi considerado relevante nesta pesquisa.

Tabela 8 - Quantidade e proporção de usuários dos edifícios do TCU em Brasília/DF

\begin{tabular}{|c|c|c|c|c|c|c|c|}
\hline \multirow{2}{*}{ Usuário } & \multicolumn{5}{|c|}{ Local de trabalho } & \multirow{2}{*}{$\begin{array}{l}\text { Total por tipo } \\
\text { de usuário }\end{array}$} & \multirow{2}{*}{ Proporção } \\
\hline & Sede & Anexo I & Anexo II & Anexo III & Restaurante & & \\
\hline $\begin{array}{l}\text { Autoridade ou } \\
\text { Servidor }\end{array}$ & 537 & 532 & 458 & 494 & 1 & 2.022 & $53,92 \%$ \\
\hline Terceirizado & 138 & 223 & 290 & 144 & 33 & 828 & $22,08 \%$ \\
\hline Estagiário & 158 & 157 & 135 & 145 & 5 & 600 & $16,00 \%$ \\
\hline Visitante & 58 & 58 & 50 & 54 & 80 & 300 & $8,00 \%$ \\
\hline $\begin{array}{c}\text { Total por local } \\
\text { de trabalho }\end{array}$ & 892 & 970 & 933 & 837 & 119 & 3.750 & \\
\hline Proporção & $23,77 \%$ & $25,85 \%$ & $24,87 \%$ & $22,32 \%$ & $3,18 \%$ & & \\
\hline
\end{tabular}

Fonte: TCU

Algumas informações relativas à ocupação do edifício foram obtidas por meio de ponderação de dados, visto que não existiam registros de população separada por edifício, mas tão somente a população total. As informações acerca da população separada por tipo de usuário foram obtidas no Relatório de Atividades do TCU relativo ao $1^{\circ}$ trimestre deste ano (2015) e em informações disponibilizadas pela área de gestão de pessoas do TCU.

De posse das informações detalhadas de área de cada um dos edifícios do complexo arquitetônico do TCU, foi feita uma análise para verificar se havia alguma discrepância entre as proporções de cada dado de cada edifício em relação ao conjunto edificado. Os dados constantes da Tabela 9 foram obtidos por meio de levantamentos em desenhos arquitetônicos dos edifícios e de informações fornecidas pela Secretaria de Engenharia do TCU.

Tabela 9 - Representatividade de variáveis de consumo de água no conjunto edificado do TCU em Brasília/DF

\begin{tabular}{|c||c|c||c|c||c|c||c|c||c|c|}
\hline Edifício & $\begin{array}{c}\text { Área } \\
\text { cobertura } \\
\left(\mathbf{m}^{2}\right)\end{array}$ & Proporção & $\begin{array}{c}\text { Área sem } \\
\text { garagens } \\
\left(\mathbf{m}^{2}\right)\end{array}$ & Proporção & $\begin{array}{c}\text { Área } \\
\text { escritórios } \\
\left(\mathbf{m}^{\mathbf{2}}\right)\end{array}$ & Proporção & $\begin{array}{c}\text { Áreas } \\
\text { molhadas } \\
\left(\mathbf{m}^{\mathbf{2}}\right)\end{array}$ & Proporção & População & Proporção \\
\hline Sede & $4.311,00$ & $38,10 \%$ & $21.903,00$ & $32,98 \%$ & $11.701,14$ & $35,13 \%$ & $1.056,95$ & $28,07 \%$ & 1.413 & $37,67 \%$ \\
\hline Anexo I & $1.821,17$ & $16,10 \%$ & $10.963,00$ & $16,51 \%$ & $5.501,85$ & $16,52 \%$ & 732,73 & $19,46 \%$ & 580 & $15,48 \%$ \\
\hline Anexo II & $2.221,41$ & $19,63 \%$ & $13.328,45$ & $20,07 \%$ & $7.181,90$ & $21,56 \%$ & 680,66 & $18,08 \%$ & 822 & $21,92 \%$ \\
\hline Anexo III & $2.266,25$ & $20,03 \%$ & $18.130,01$ & $27,30 \%$ & $8.563,45$ & $25,71 \%$ & $1.152,16$ & $30,60 \%$ & 816 & $21,76 \%$ \\
\hline Restaurante & 694,71 & $6,14 \%$ & $2.084,14$ & $3,14 \%$ & 356,79 & $1,07 \%$ & 142,25 & $3,78 \%$ & 119 & $3,18 \%$ \\
\hline Total & $11.314,54$ & $100 \%$ & $66.408,60$ & $100 \%$ & $36.547,68$ & $100 \%$ & $3.764,75$ & $100 \%$ & 3.750 & $100,00 \%$ \\
\hline
\end{tabular}


Foram considerados os seguintes dados como significativos para esta pesquisa, em cada edifício: a população, a área construída total (sem garagens), a área de escritórios, a área de ambientes laváveis (áreas molhadas) e a área de cobertura. Numa análise dos dados, percebeuse uma discrepância de representatividade apenas no Restaurante, tendo em vista que sua utilização é especial. Como uma tentativa de reduzir tais diferenças, foi adotada a média aritmética das representatividades encontradas nas diversas variáveis levantadas, resultando nos números constantes do Gráfico 2, adotados em cálculos diversos de indicadores.

Gráfico 2 - Representatividade dos edifícios do TCU adotada na pesquisa

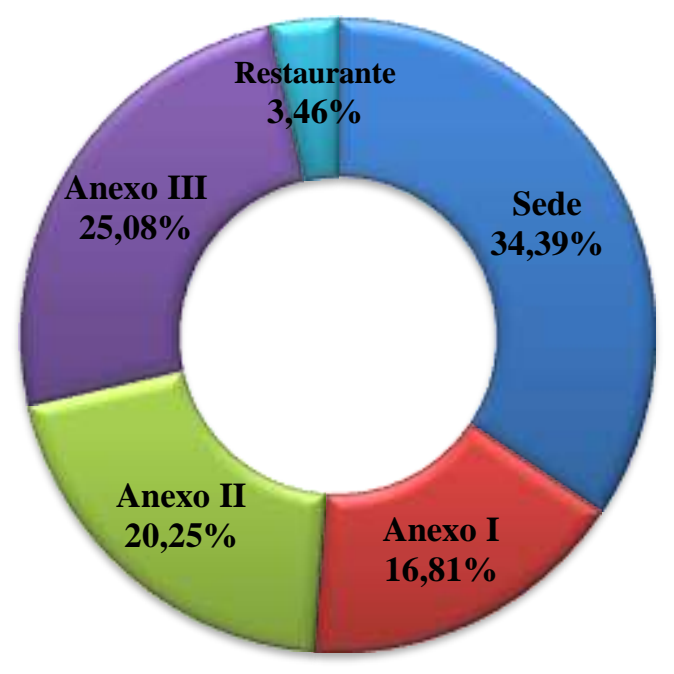

Conforme os dados do Gráfico 2 e da Tabela 9, pode se observar que, quando consideradas as variáveis de áreas e população, há uma grande representatividade do Edifício-Sede, uma distribuição próxima entre os três anexos e uma diminuta importância do Restaurante. Tais variáveis contribuirão para a definição de parâmetros no conjunto edificado do TCU. Entretanto, ao analisar os edifícios separadamente, os dados passam a não ser tão relevantes, especialmente pela função distinta do Restaurante.

O Edifício-Sede possui uma planta quadrada com varandas externas ao longo de todo o perímetro, além de jardins internos e externos com paisagismo assinado pelo paisagista Burle Marx. Há corredores internos que dividem os ambientes administrativos, que têm suas faces voltadas para essas varandas ou para o jardim interno. Na Foto 6 é mostrado esse jardim interno e parte dos espelhos d'água que circundam o Edifício-Sede, que, como na foto, tem períodos de manutenção, especialmente para reparos na impermeabilização.

Conforme a Figura 13 e a Foto 7, observa-se que o Edifício-Sede, em seus pavimentos-tipo, abriga dois grupos de sanitários e copas, localizados em pontos opostos, bem como sanitários 
privativos, sempre contíguos a shafts com disposição fixa nos pavimentos, que atendem às autoridades e aos respectivos servidores lotados nos gabinetes. Os pavimentos do mezanino e subsolo possuem áreas de sanitários dispersas. O auditório de 250 lugares, localizado no pavimento térreo, possui também sanitários próprios.

Foto 6 - Espelhos d'água superior (em manutenção) e jardins externos e internos do TCU em Brasília/DF
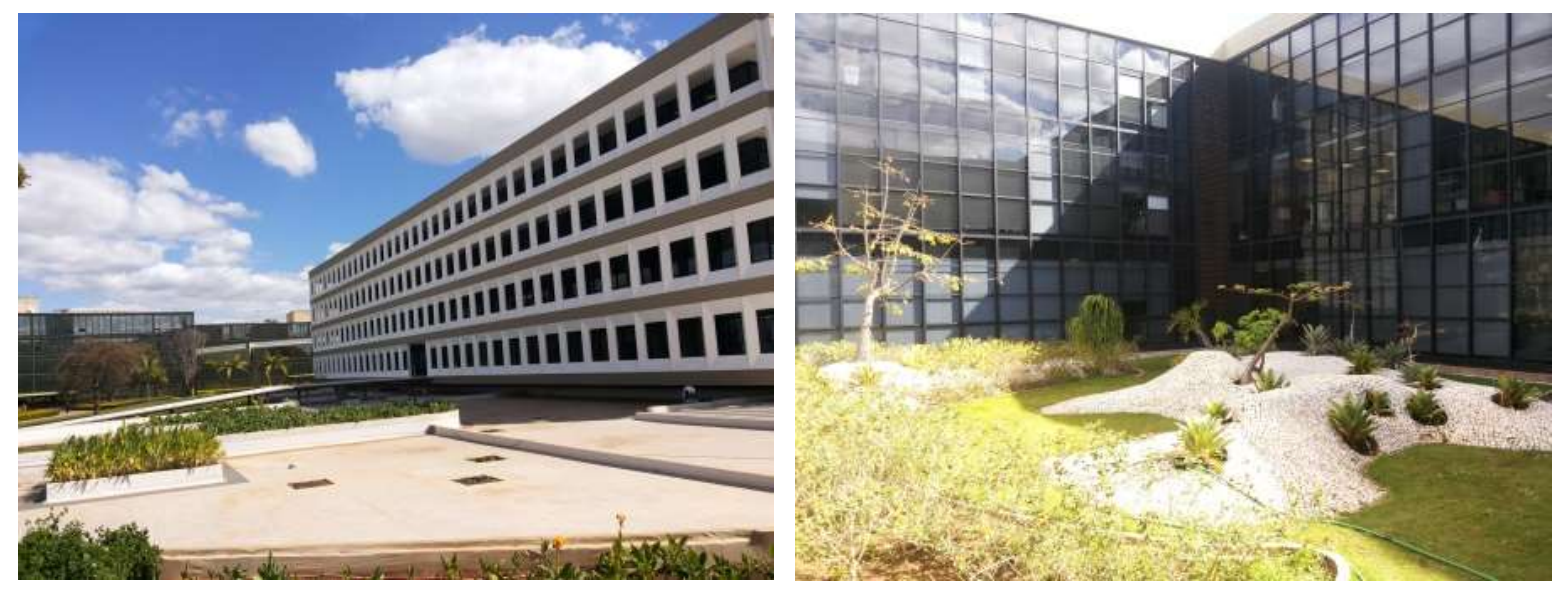

Fonte: TCU

Figura 13 - Planta baixa de pavimento tipo do Edifício-Sede do TCU em Brasília/DF
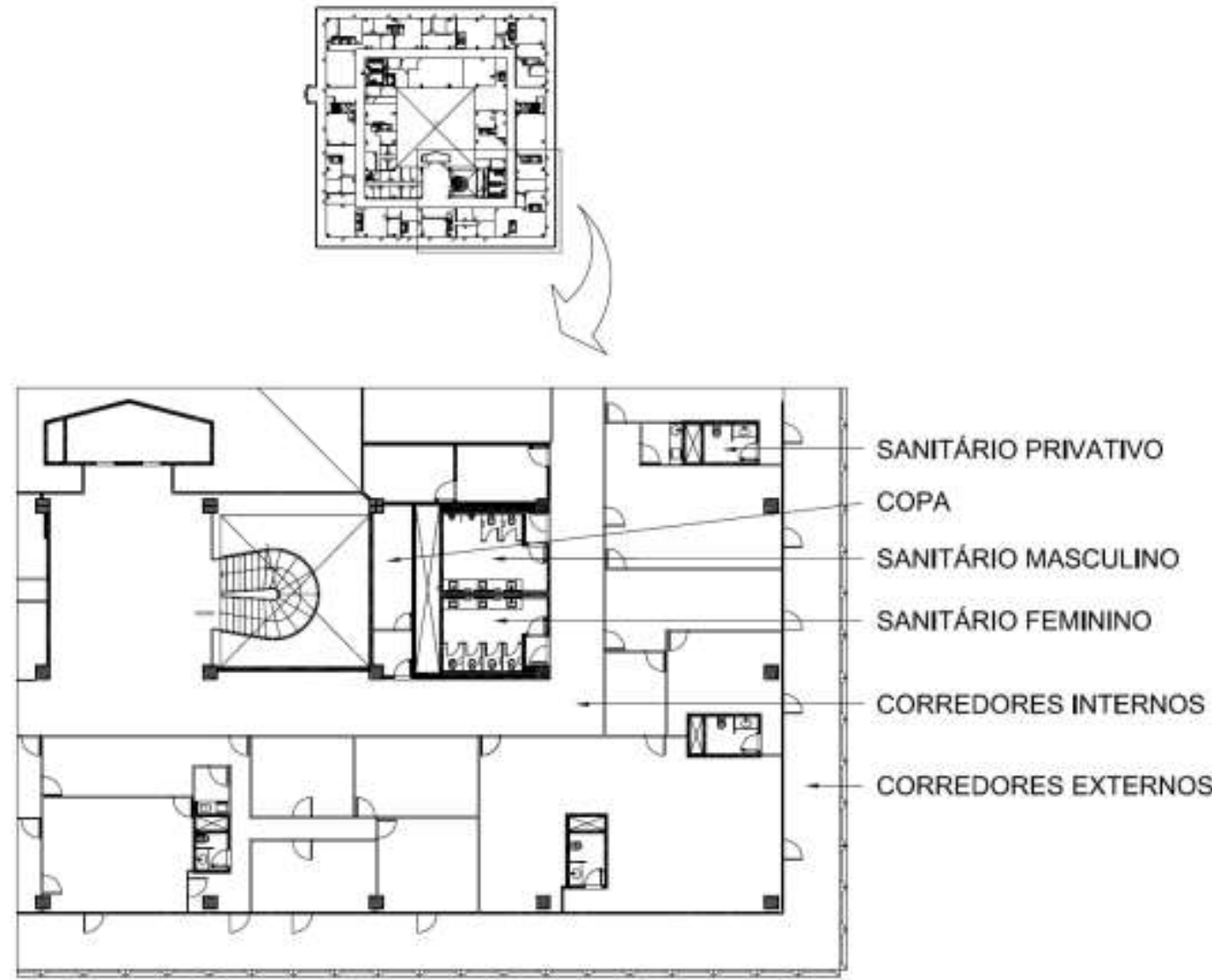

Fonte: TCU 
Foto 7 - Peças sanitárias do Edifício-Sede do TCU em Brasília/DF
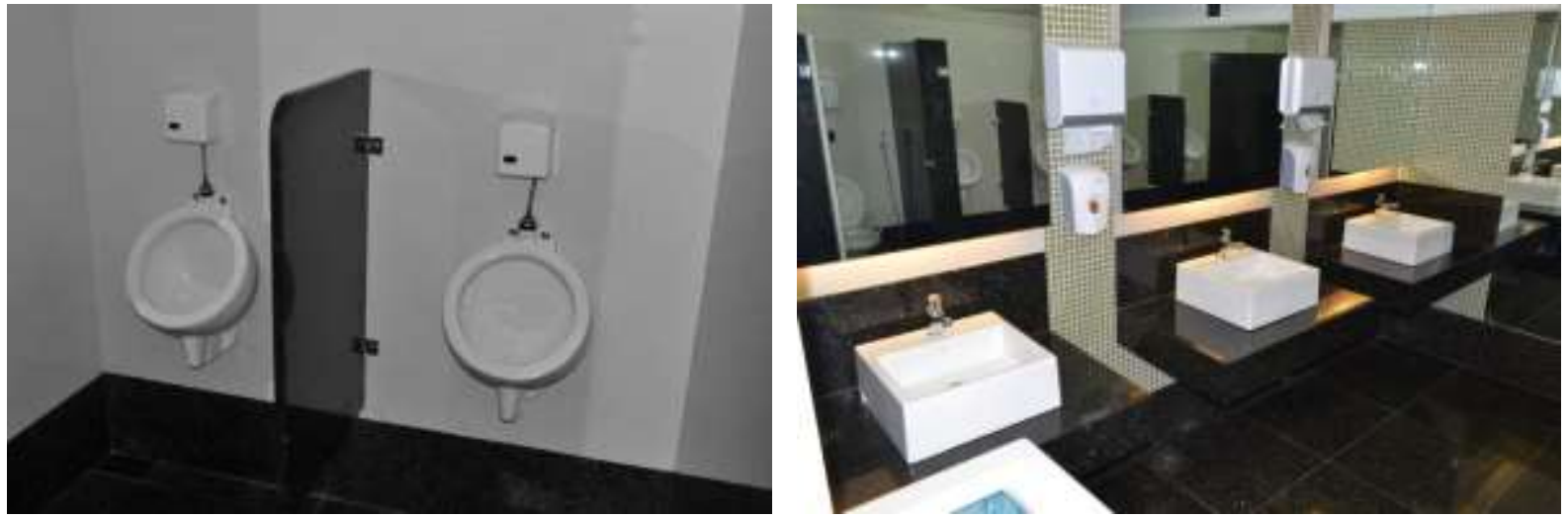

Fonte: TCU

Os Anexos I, II e III possuem formato radial e também dispõem de dois grupos de sanitários e copas por andar de pavimento-tipo, conforme Figura 14 e Fotos 8 e 9. Esses edifícios têm previsão para instalação de sanitários privativos em shafts localizados próximos aos corredores, bem como sanitários para portadores de necessidades especiais (PNEs) em todos os andares. $\mathrm{O}$ acesso à passarela de interligação acontece no $2^{\circ}$ andar. A geometria dos três anexos é muito semelhante na sua essência e se difere basicamente em seu comprimento. Foi exemplificado na Figura 14 apenas um desses edifícios.

Figura 14 - Planta baixa de pavimento-tipo dos Anexos I, II e III do TCU em Brasília/DF

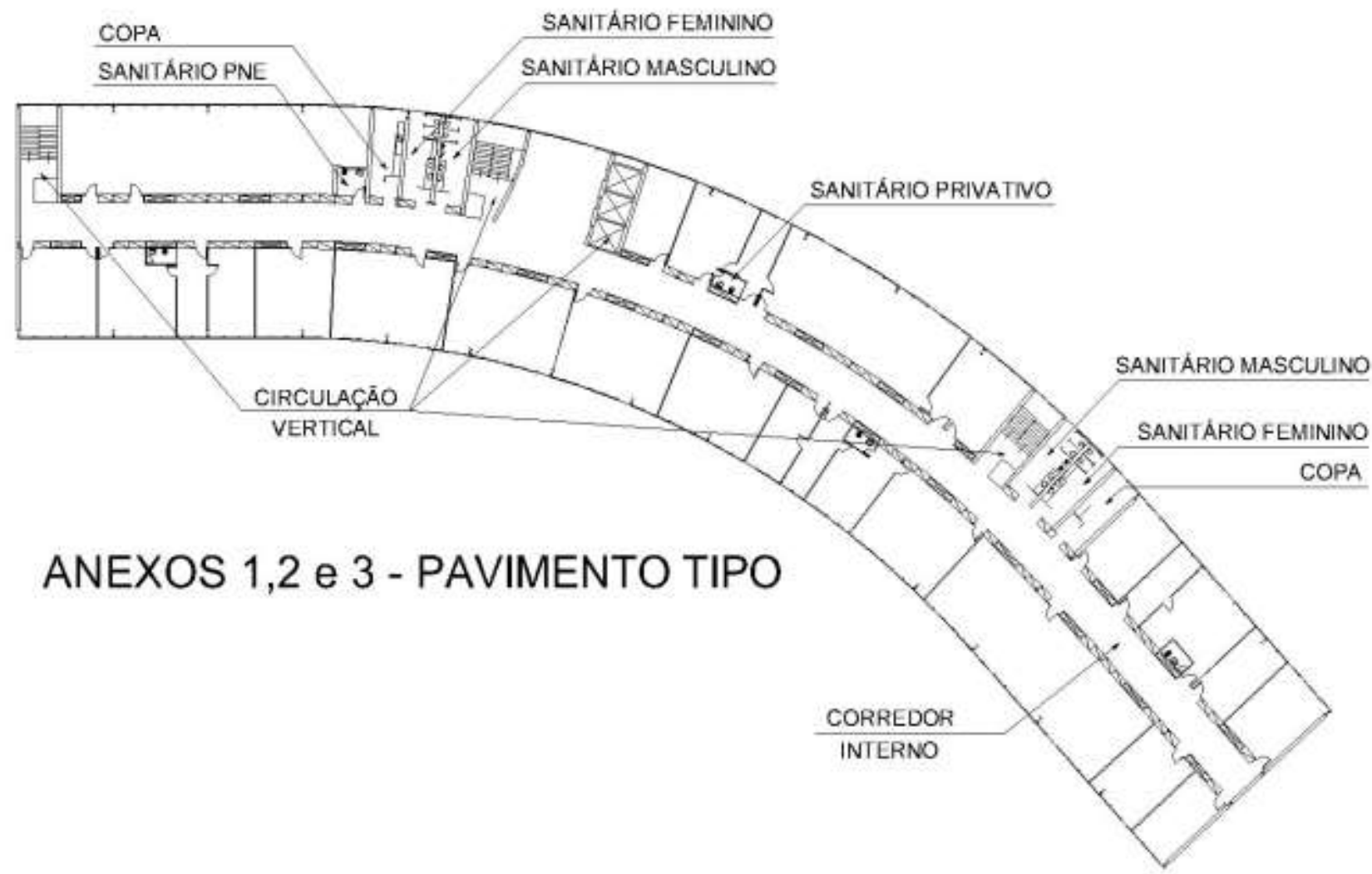

Fonte: TCU 
Foto 8 - Vistas externas dos Anexos do TCU em Brasília/DF
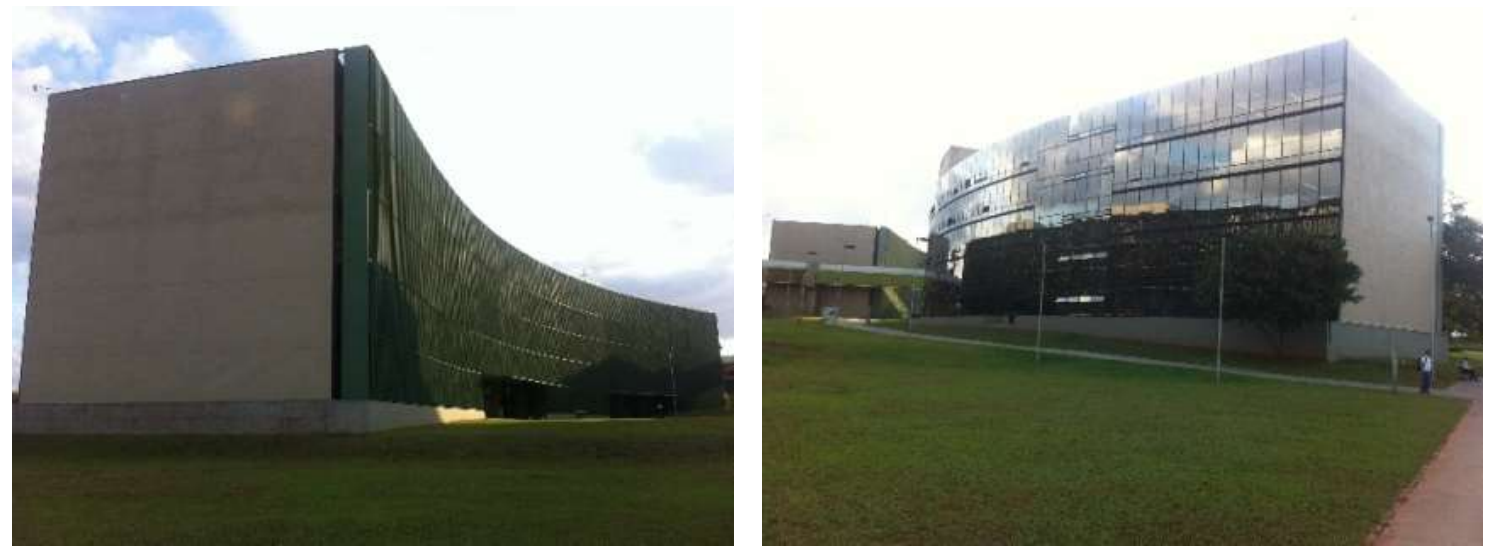

Fonte: TCU

Foto 9 - Peças sanitárias e das copas dos Anexos I, II, III e Restaurante do TCU em Brasília/DF
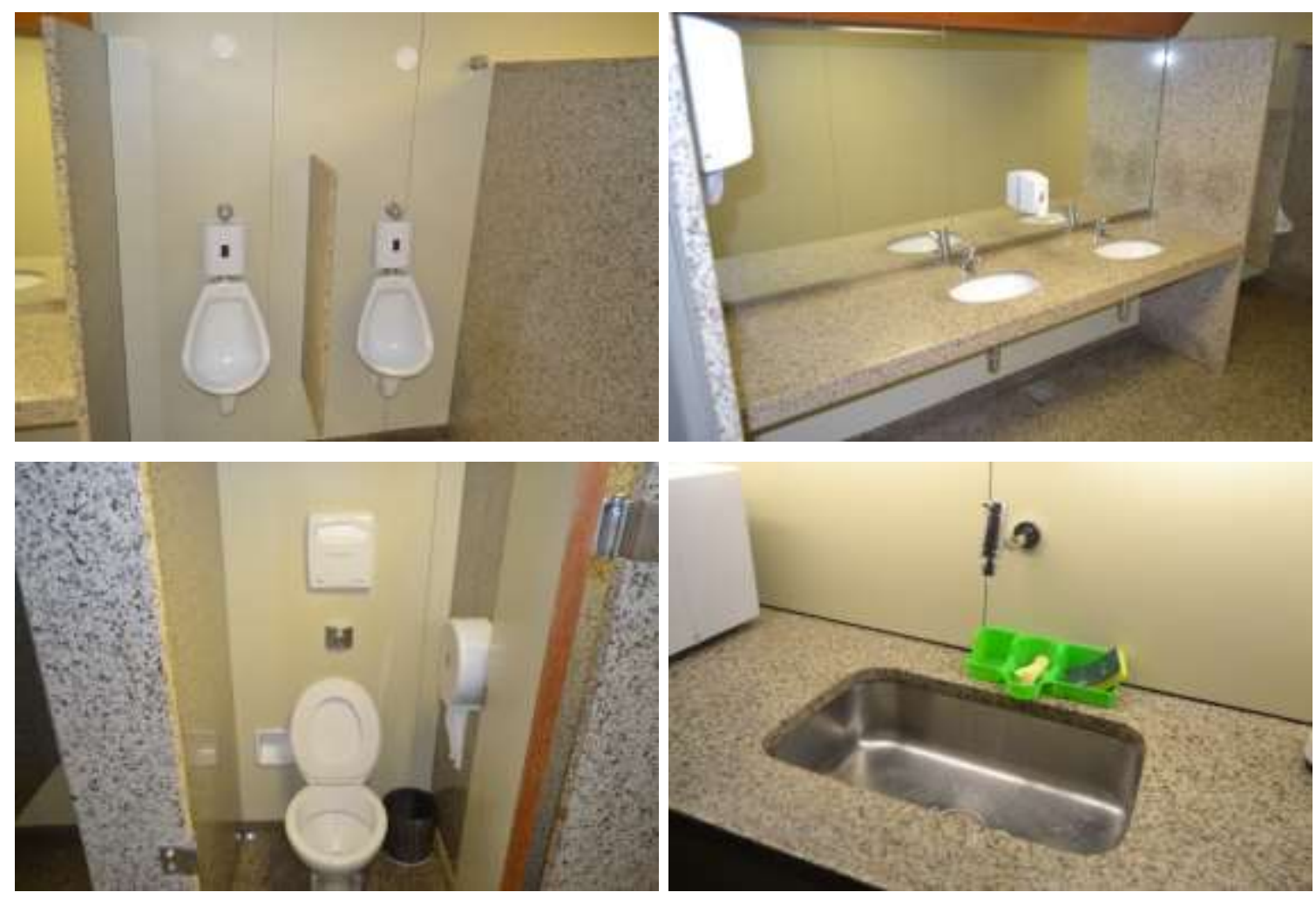

Fonte: TCU

O Restaurante do TCU tem formato circular e possui dois pavimentos para alimentação pelo sistema de autosserviço, como mostra a Figura 15. No segundo subsolo localizam-se os vestiários dos funcionários e no primeiro subsolo a cozinha industrial, com vários pontos de uso de água: a área de cocção propriamente dita, preparação de guarnições, saladas, confeitaria e lavagem de panelas, entre outros locais, conforme ilustrados nas Fotos 10 e 11. 
Todos os pavimentos são interligados por escada interna e por elevadores monta-cargas para o transporte dos alimentos. O pavimento inferior dispõe de serviços especiais de buffet de saladas e de churrasco, em bancadas especiais, bem como serviços de lanchonete, no período da tarde.

Figura 15 - Plantas baixas do Restaurante do TCU em Brasília/DF
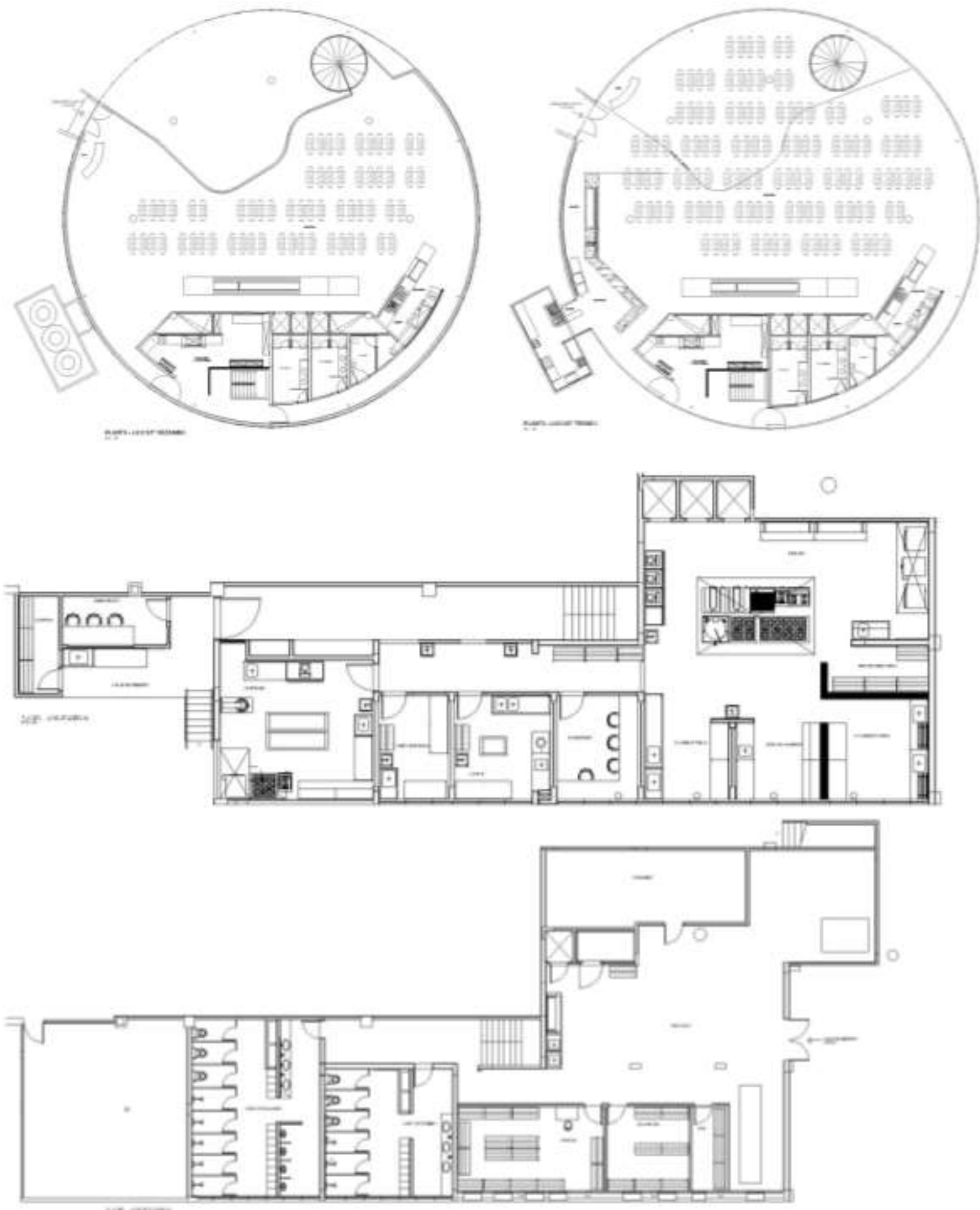

Fonte: TCU 
Foto 10 - Áreas de trabalho na cozinha industrial do Restaurante do TCU em Brasília/DF
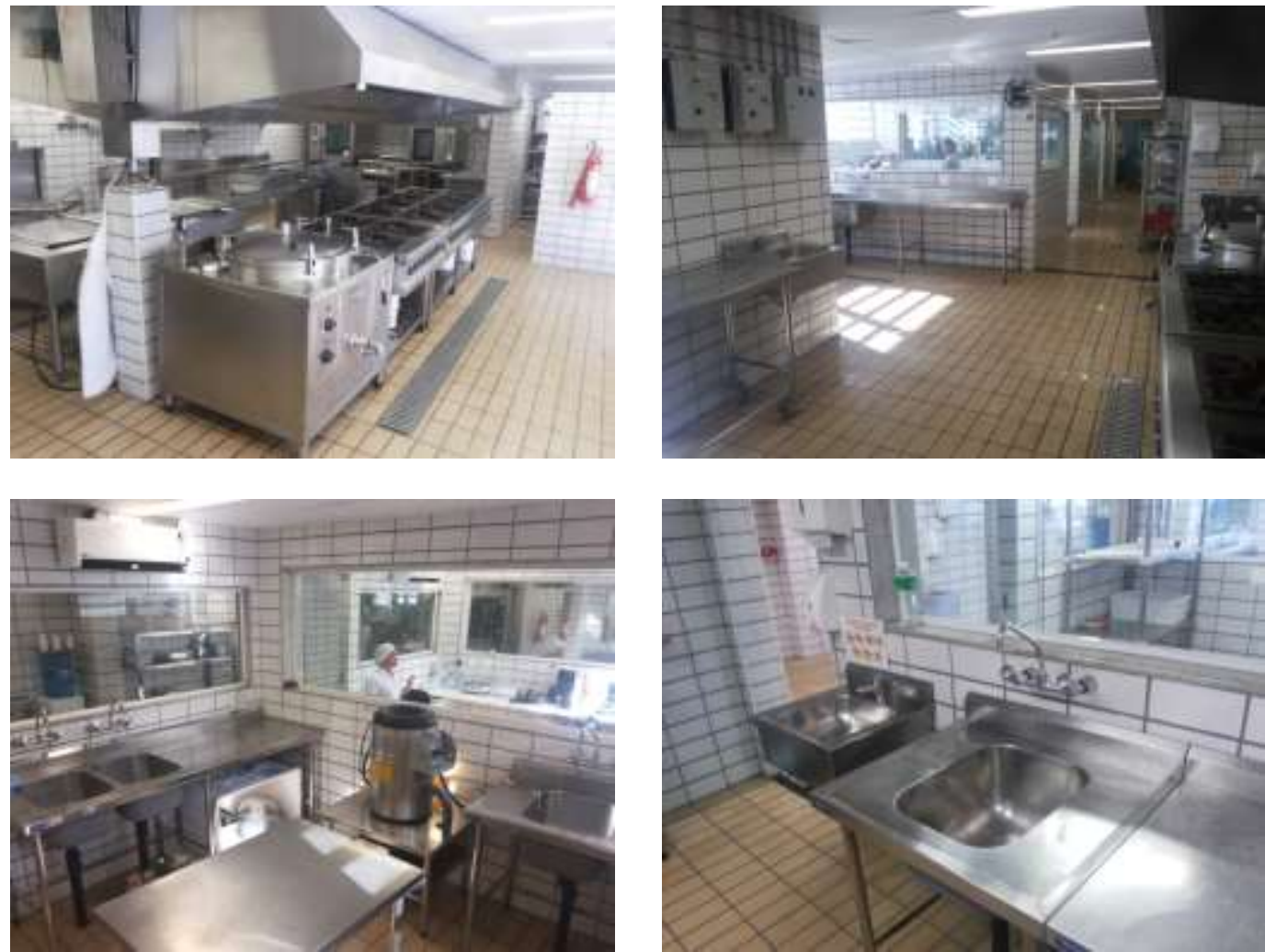

Fonte: TCU

Foto 11 - Ambiente externo e interno do Restaurante do TCU em Brasília/DF

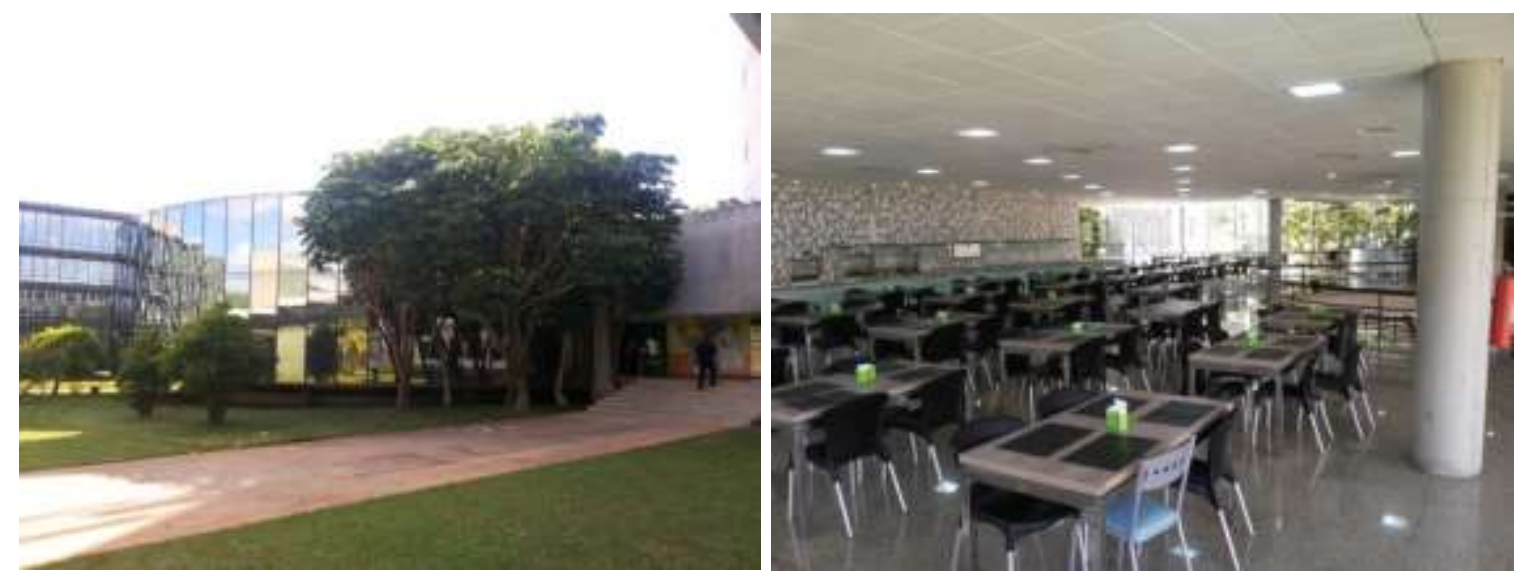

Fonte: TCU

\subsubsection{Análise do consumo histórico}

Seguindo as recomendações de ANA et al. (2005), obtiveram-se os dados de consumo histórico do conjunto edificado do TCU, recorrendo-se às contas de água ao longo dos últimos anos. Como forma de delimitação do objeto estudado, foram considerados como período inicial as contas do mês de janeiro de 2009 (Edifício-Sede, Anexos I, II e Restaurante) ou janeiro de 2012 (Anexo III) e o período final as contas relativas ao consumo de junho de 2015. A síntese dos dados de consumo deste período está mostrada na Tabela 10. 
Tabela 10 - Síntese do consumo médio de água do conjunto edificado do TCU em Brasília/DF

\begin{tabular}{|c|c|c|c|c|c|c|c|c|c|}
\hline \multirow[b]{2}{*}{ Período } & \multicolumn{3}{|c|}{ Edificio Sede } & \multicolumn{3}{|c|}{ Anexos I, II e Restaurante } & \multicolumn{3}{|c|}{ Anexo III } \\
\hline & $\begin{array}{c}\text { Consumo } \\
\text { médio } \\
\left(\mathbf{m}^{3}\right) \\
\end{array}$ & $\begin{array}{c}\text { Valor } \\
\text { médio } \\
(\mathrm{R} \$)\end{array}$ & $\begin{array}{c}\text { Valor } \\
\mathbf{m}^{3} \\
(\mathbf{R} \$) \\
\end{array}$ & $\begin{array}{c}\text { Consumo } \\
\text { médio } \\
\left(\mathbf{m}^{3}\right)\end{array}$ & $\begin{array}{c}\text { Valor } \\
\text { médio } \\
(\mathbf{R} \$)\end{array}$ & $\begin{array}{c}\text { Valor } \\
\mathbf{m}^{3} \\
(\mathbf{R} \$) \\
\end{array}$ & $\begin{array}{c}\text { Consumo } \\
\text { médio } \\
\left(\mathbf{m}^{3}\right)\end{array}$ & $\begin{array}{c}\text { Valor } \\
\text { médio } \\
(\mathbf{R} \$)\end{array}$ & $\begin{array}{c}\text { Valor } \\
\mathbf{m}^{3} \\
(\mathbf{R} \$) \\
\end{array}$ \\
\hline 2009 & 1286,33 & $16.082,78$ & 12,51 & $2.279,67$ & $28.678,45$ & 12,53 & & & \\
\hline 2010 & 1387,83 & $18.282,73$ & 13,12 & $2.568,17$ & $33.767,17$ & 13,13 & & & \\
\hline 2011 & 1435,33 & $20.228,20$ & 13,96 & $3.093,75$ & $43.467,16$ & 13,99 & & & \\
\hline 2012 & 1149,75 & $17.783,38$ & 15,35 & $2.430,92$ & $37.748,99$ & 15,42 & 825,17 & $11.936,44$ & 14,15 \\
\hline 2013 & 1039,83 & $17.654,59$ & 16,88 & $2.986,17$ & $50.893,83$ & 16,95 & 878,75 & $14.937,38$ & 16,89 \\
\hline 2014 & 882,67 & $16.224,47$ & 18,10 & $2.665,08$ & $48.770,71$ & 18,28 & 805,42 & $14.742,39$ & 18,21 \\
\hline Até $6 / 2015$ & 570,83 & $11.463,06$ & 20,48 & $2.446,83$ & $50.796,14$ & 20,63 & 987,00 & $19.700,38$ & 20,56 \\
\hline Média & 1107,51 & $16.817,03$ & 15,77 & $2.638,65$ & $42.017,49$ & 15,85 & 874,08 & $15.329,15$ & 17,45 \\
\hline
\end{tabular}

Fonte: TCU

Observa-se que há uma tendência de queda no consumo dos edifícios, exceto no caso do Anexo III, onde se registrou um aumento em 2015, mesmo sendo considerada apenas metade do tempo de consumo. O Gráfico 3 mostra também que houve aumento fora do comum da tarifa aplicada pela concessionária no ano de 2015, reflexo da crise hídrica que atinge o país.

Tais tendências são identificadas ao se analisar os Gráficos 4 a 6, que contêm dados climatológicos de precipitação e de umidade relativa do ar, referentes ao período em que foram disponibilizados os dados mensais de consumo de água dos edifícios componentes do conjunto edificado do TCU, levantados junto à base de dados do Instituto Nacional de Meteorologia (INMET), referentes à estação meteorológica de Brasília.

Os cruzamentos desses dados foram inseridos nesta pesquisa para identificar correlações entre eles e as tendências de consumo para os períodos de maiores ou menores umidades relativas e precipitações.

Gráfico 3 - Variação do reajuste de tarifas de água no conjunto edificado do TCU em Brasília/DF

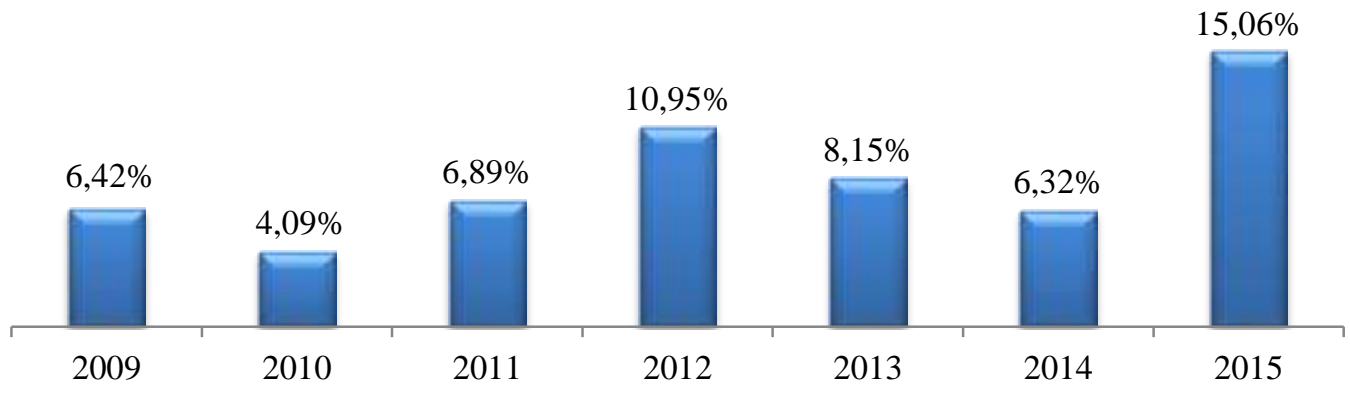

Fonte: TCU 
Gráfico 4 - Dados climatológicos comparados com o consumo mensal do Edifício-Sede do TCU em Brasília/DF (período de 2009 a 2014)

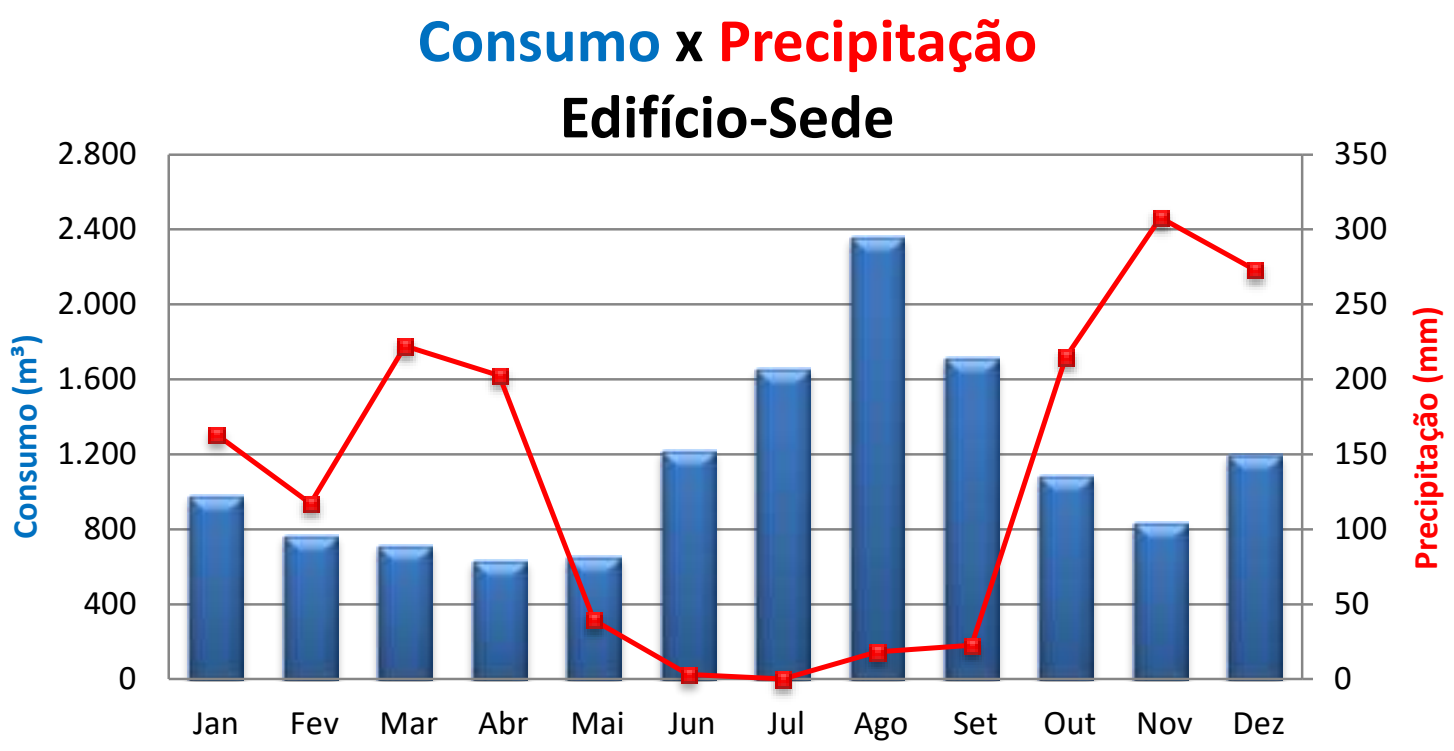

\section{Consumo x Umidade Relativa}

Edifício-Sede

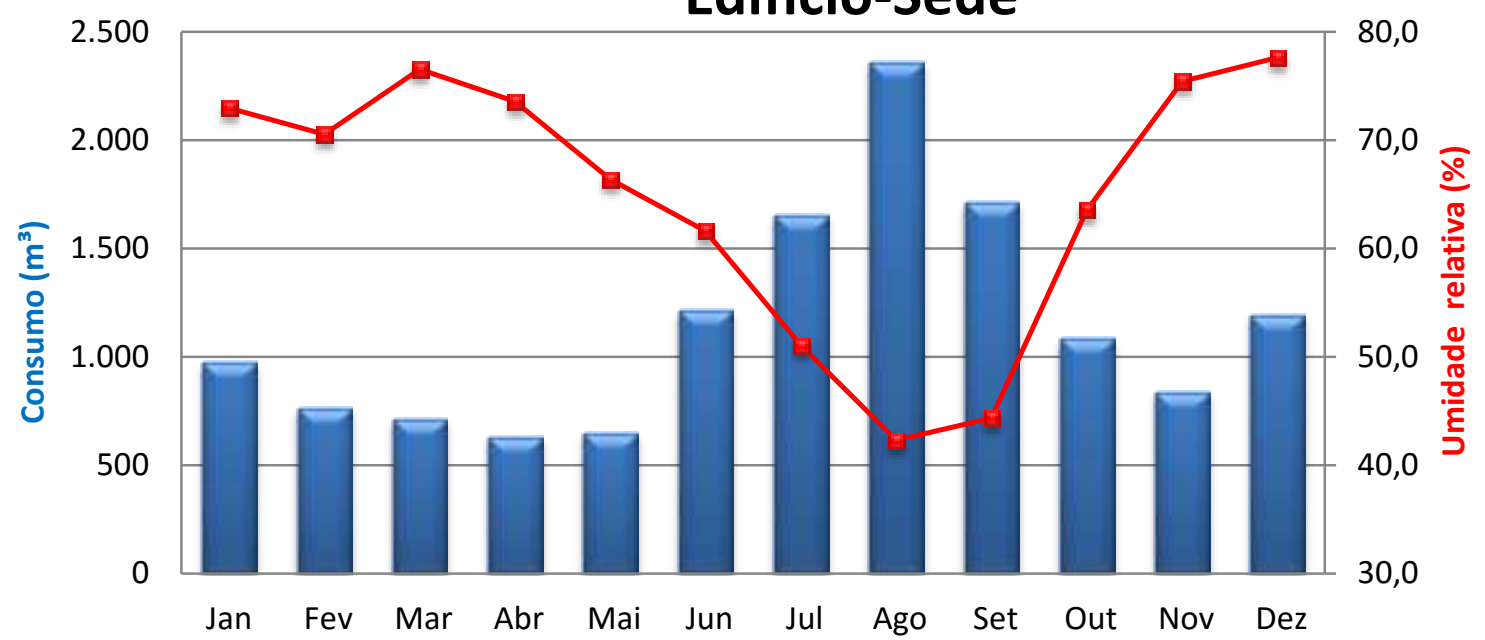

Fontes: INMET e TCU

Há que se destacar que o Edifício-Sede teve uma melhora significativa no consumo após a reforma que foi concluída em 2014, pois houve troca de louças, metais e do sistema de ar condicionado, bem como troca de tubulações antigas, ainda em ferro fundido. Dessa forma, é possível inferir que haverá uma futura redução média de consumo neste local.

O Edifício-Sede teve picos de consumo mais abruptos nos meses de seca, conforme se pode notar no Gráfico 4. Tal tendência é, em parte, explicada pelo fato de o conjunto arquitetônico em Brasília ter dois espelhos d'água com volume total de cerca de $3.280 \mathrm{~m}^{3}$, com necessidade de esgotamentos eventuais para limpeza e recalques mais frequentes para reposição de água perdida por evaporação. Esse consumo é todo creditado à conta deste edifício. 
Gráfico 5 - Dados climatológicos comparados com o consumo mensal dos Anexos I, II e Restaurante do TCU em Brasília/DF (período de 2009 a 2014)

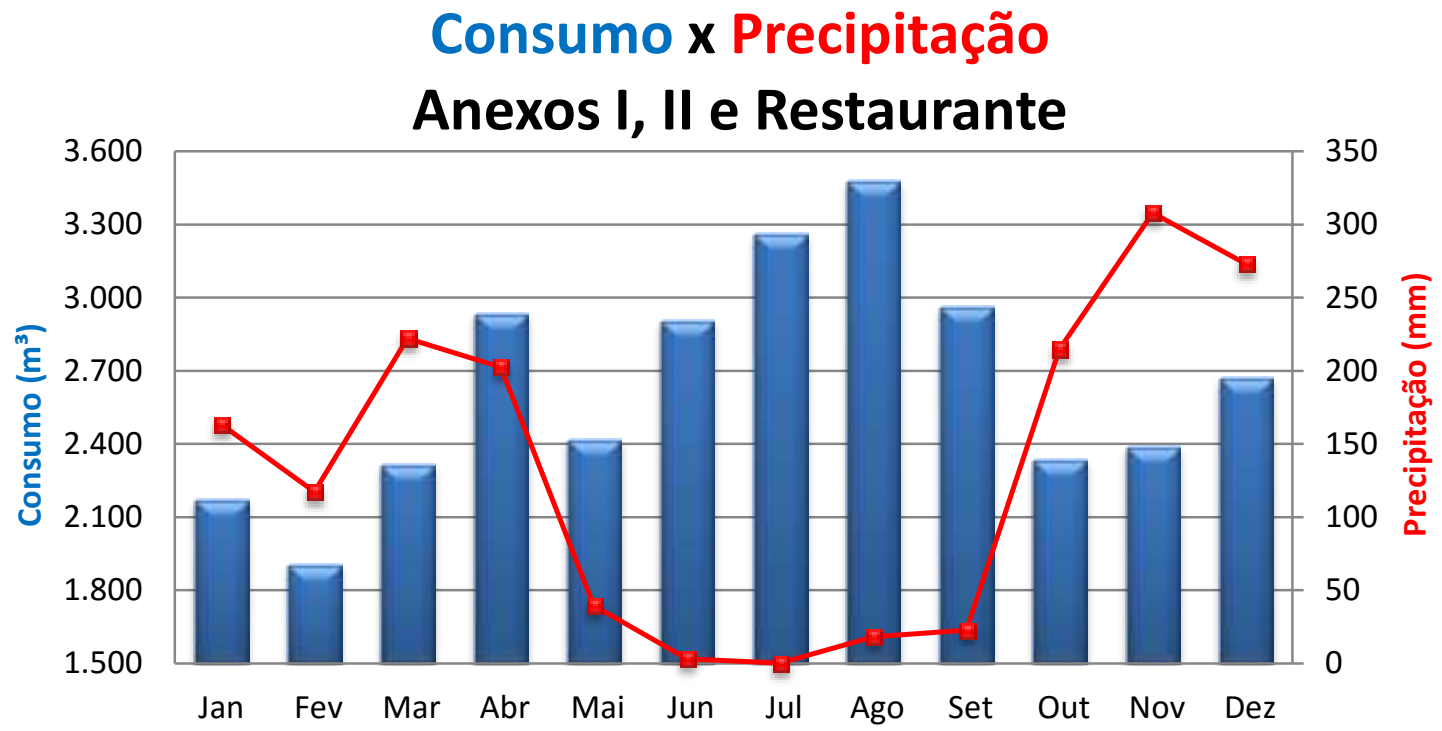

Consumo x Umidade Relativa

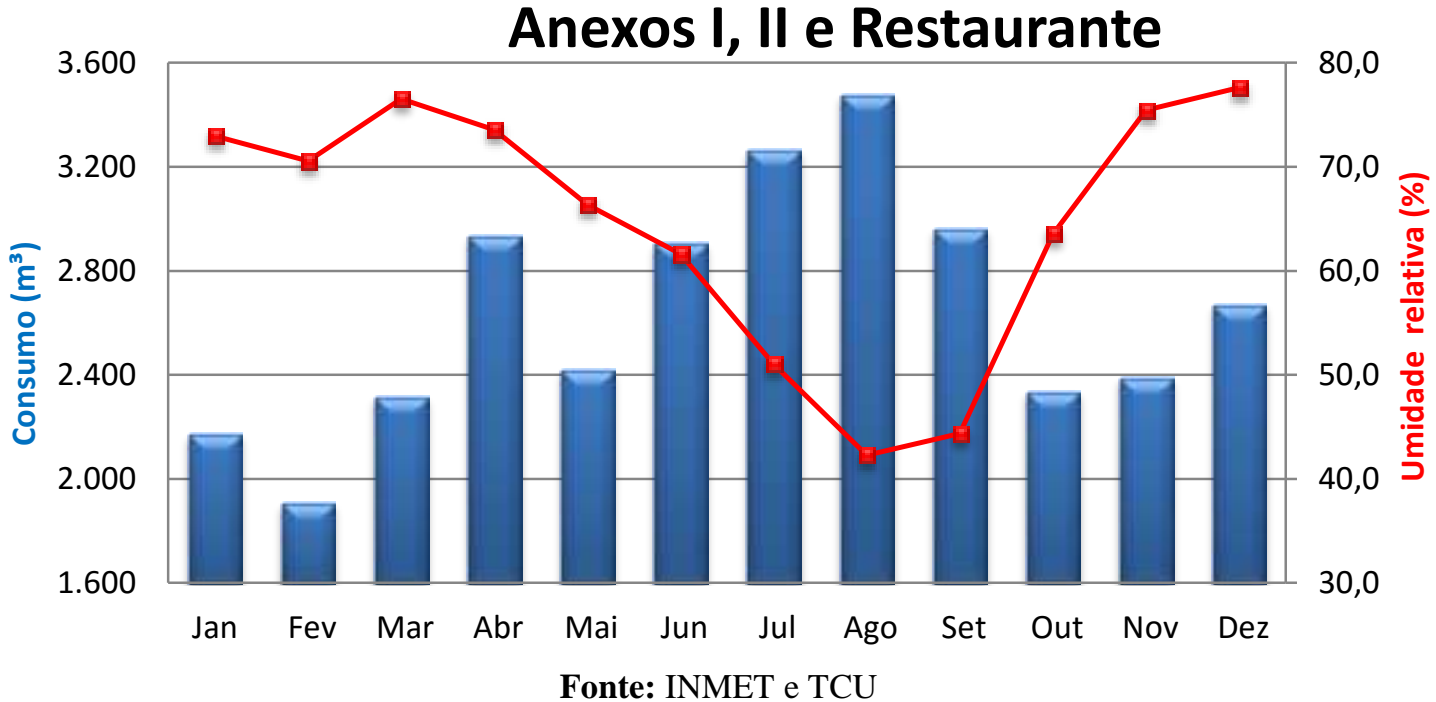

Isso explica também que, no Edifício-Sede, ocorra a maior amplitude anual de consumo, com redução de 73,2\% no consumo de abril, comparado ao de agosto. Outro fator importante é o consumo de água com irrigação, que, em meses de pouca precipitação, deve ser realizada diariamente, consumindo mais de $200 \mathrm{~m}^{3}$ de água por mês.

No caso do consumo dos Anexos I, II e Restaurante, também foi notada uma crescente de consumo nos meses de seca e um volume expressivo quanto ao consumo absoluto de água, que é justificado por dois motivos: a concentração de três edifícios em um mesmo hidrômetro e o maior consumo de irrigação, visto que o sistema fixo de aspersores é vinculado a esses edifícios. 
Gráfico 6 - Dados climatológicos comparados com o consumo mensal do Anexo III do TCU em Brasília/DF (período de 2012 a 2014)

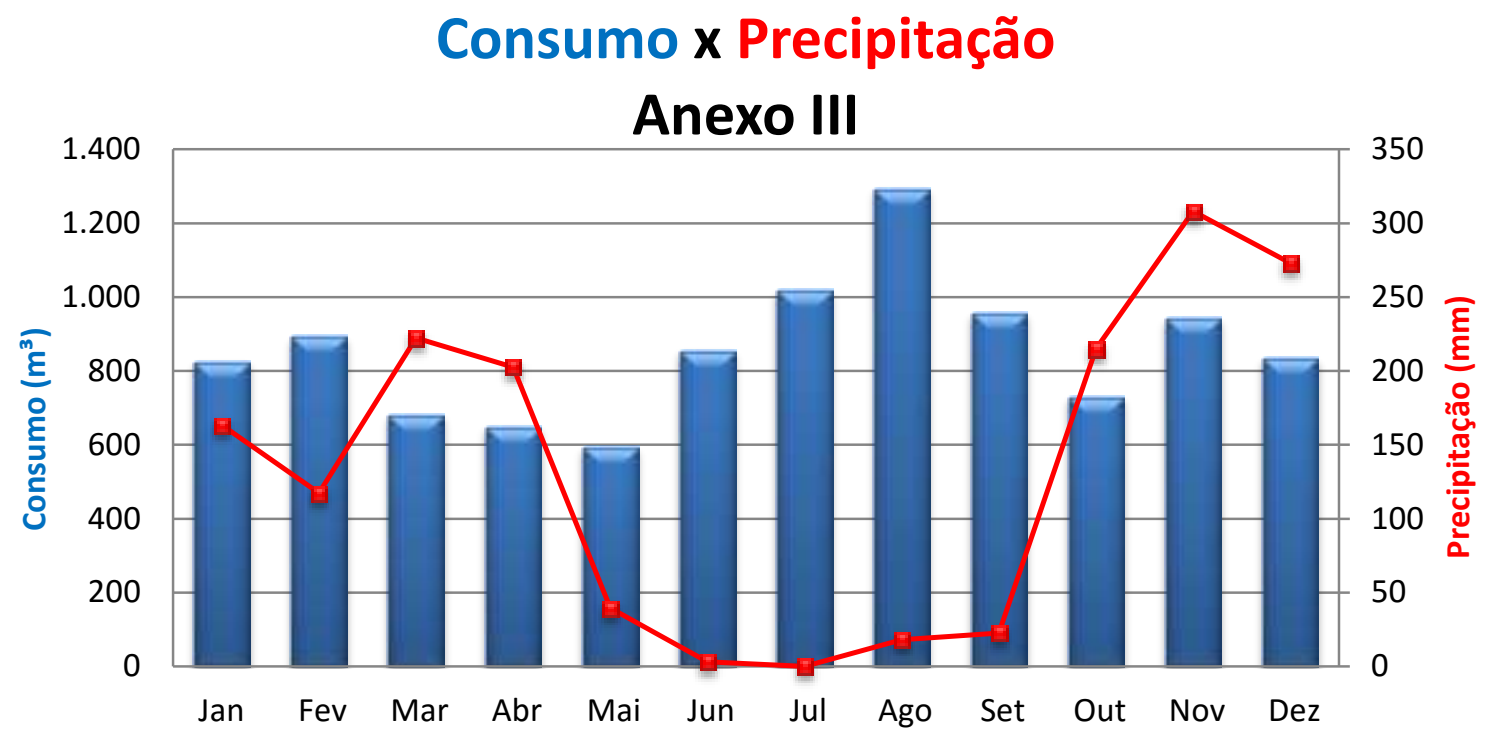

Consumo x Umidade Relativa

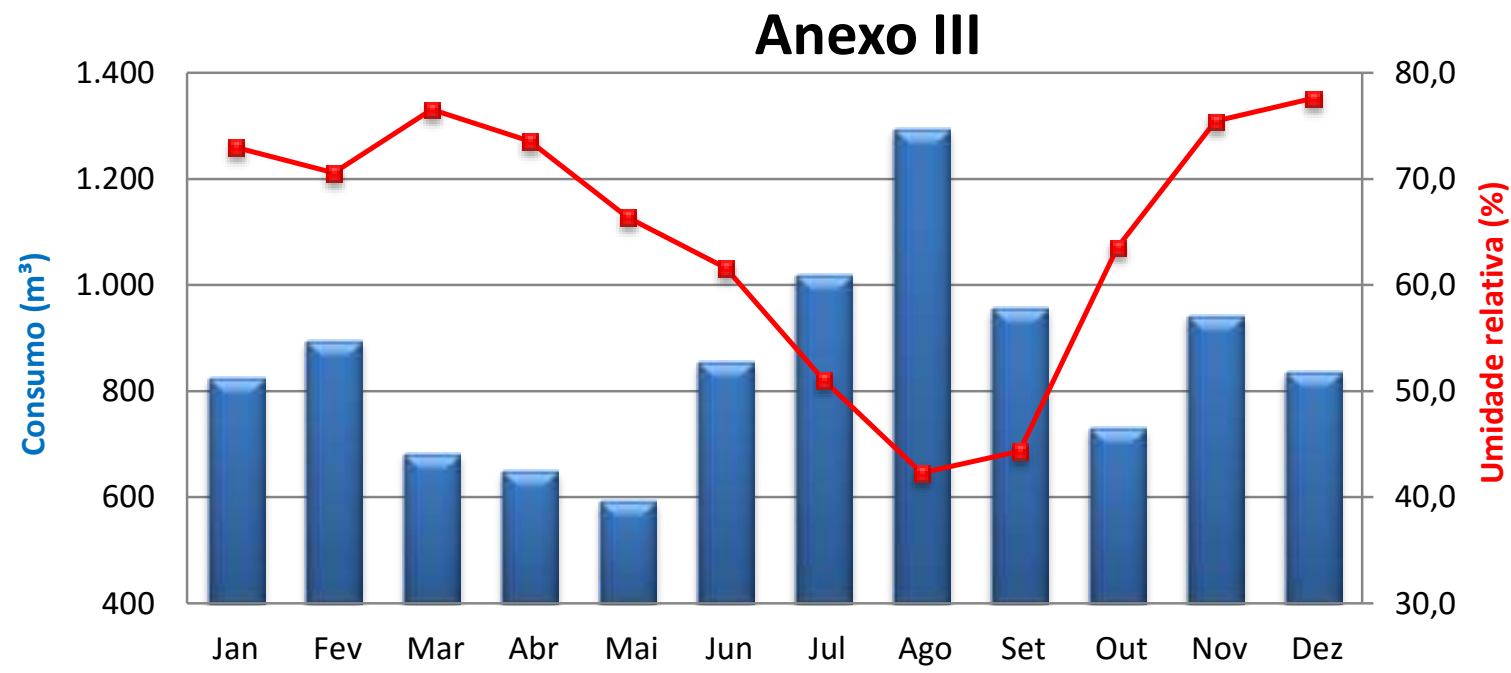

Fonte: INMET e TCU

No caso desses edifícios, a amplitude anual de consumo foi de 45,2\%, ocorrida no mês de fevereiro, novamente em comparação ao mês de agosto. Essa foi a medição na qual houve maior regularidade no seu consumo, ou seja, com menor amplitude. Isso vai de encontro, por um lado, à tendência de se verificar amplitudes maiores, dado que, em meses chuvosos, não há utilização do sistema de irrigação, responsável por parte significativa do consumo, visto mais adiante. Apesar dessa queda de consumo na irrigação, as temperaturas dos meses de verão são elevadas, podendo elevar o consumo com o uso de equipamentos.

Por fim, numa análise do Anexo III, foi percebida a diferença de 54,1\% entre os meses de maio e agosto. Nesse caso, há que se ponderar que esse edifício foi o último a ser inaugurado 
no conjunto edificado do TCU em Brasília/DF. Os dados climáticos a partir de 2012, quando se iniciou a medição de consumo de água, apontam menor ocorrência de fatos climáticos extraordinários e estações secas mais amenas, impactando diretamente no comportamento do usuário, que normalmente consome mais nos meses de maio.

Como os dados levantados de consumo de irrigação foram expressivos, foi feito o cruzamento dos mesmos dados acima com o consumo de água sem a irrigação, demonstrados no Gráfico 7, referente ao Edifício-Sede e, no Gráfico 8, referente aos Anexos I, II e Restaurante. No caso do Anexo III, não havia dados separados de consumo de irrigação.

Gráfico 7 - Dados climatológicos comparados com o consumo mensal sem irrigação do Edifício-Sede do TCU em Brasília/DF (período de 2009 a 2014)

\section{Consumo x Precipitação \\ Edifício-Sede}

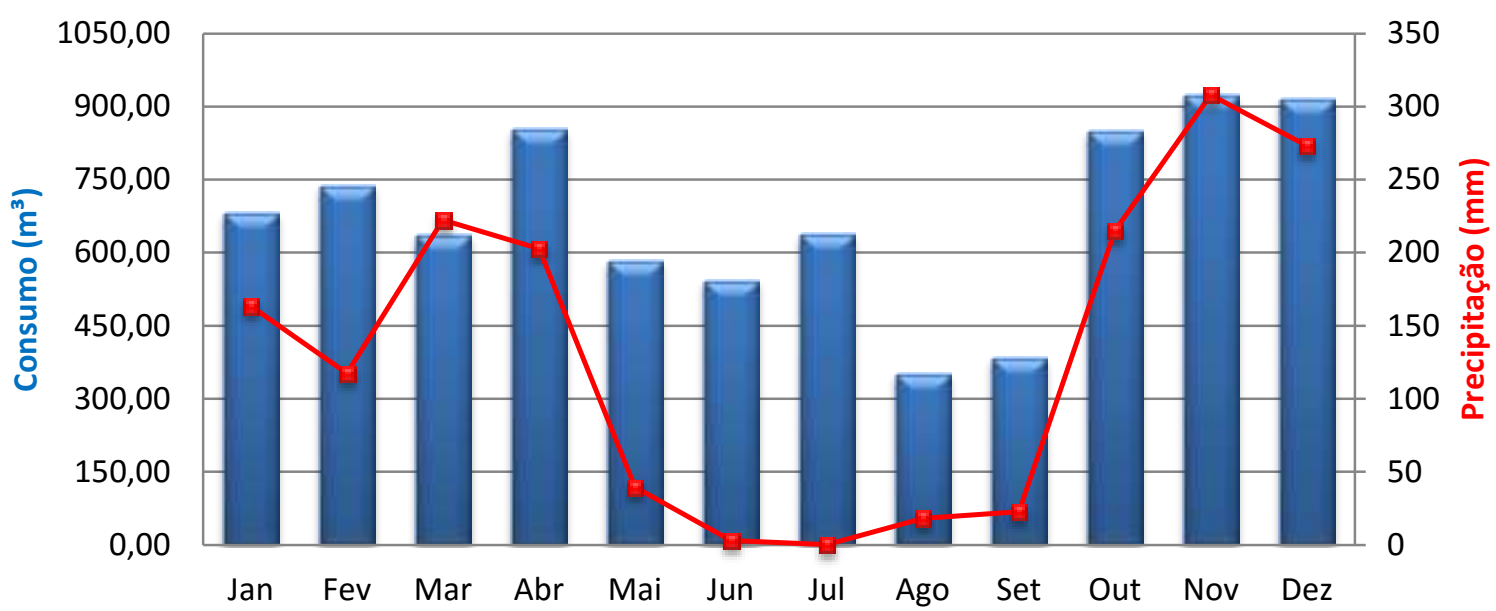

\section{Consumo x Umidade Relativa Edifício-Sede}

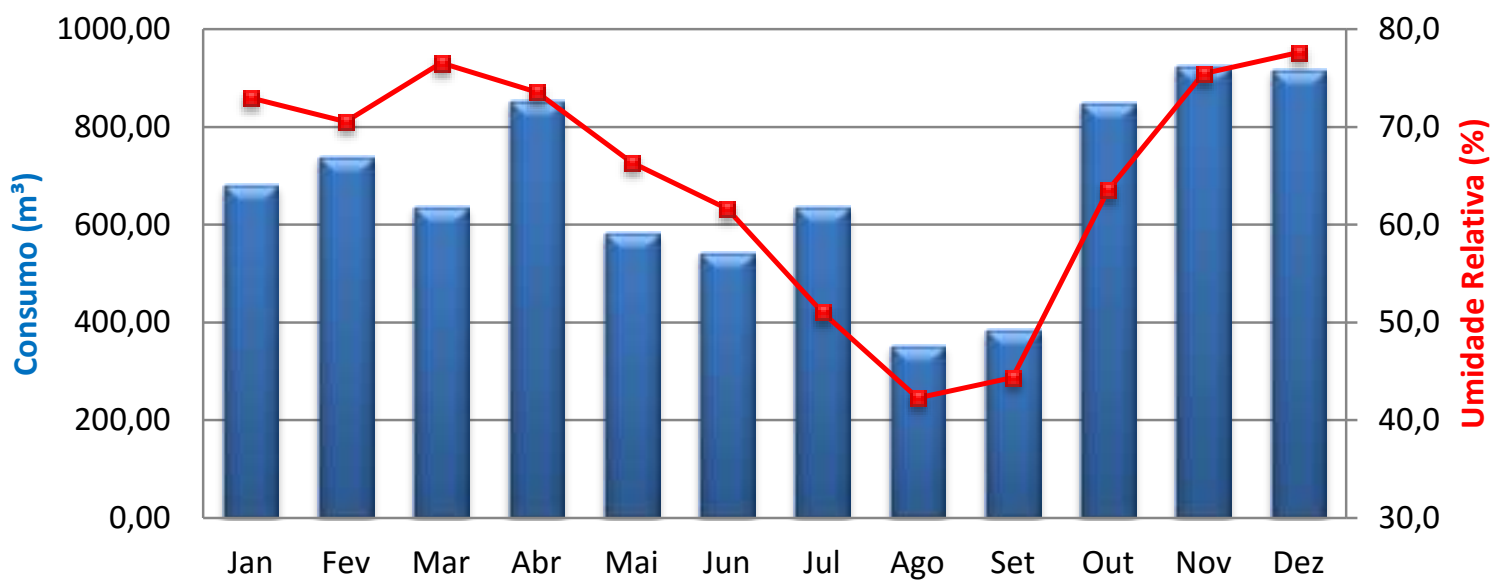


Gráfico 8 - Dados climatológicos comparados com o consumo mensal sem irrigação dos Anexos I, II e Restaurante do TCU em Brasília/DF (período de 2009 a 2014)

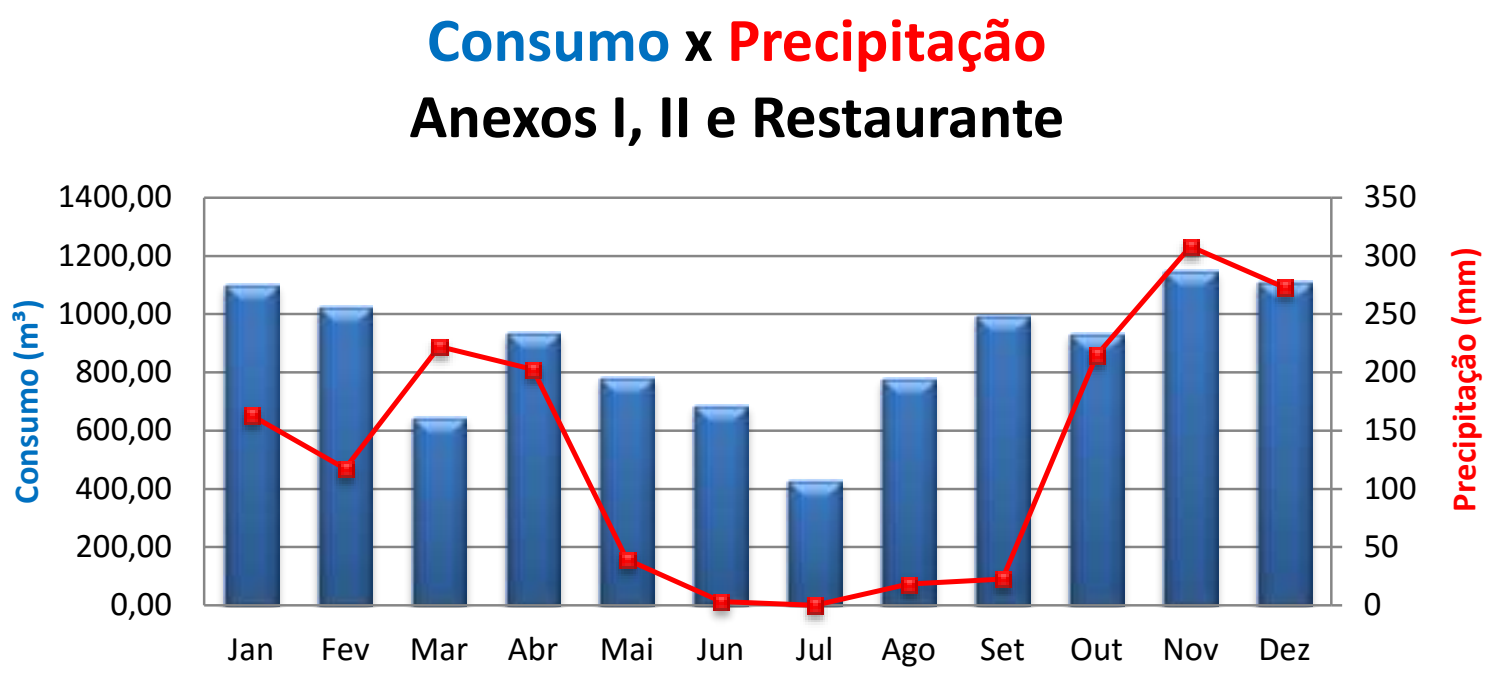

\section{Consumo x Umidade Relativa Anexos I, II e Restaurante}

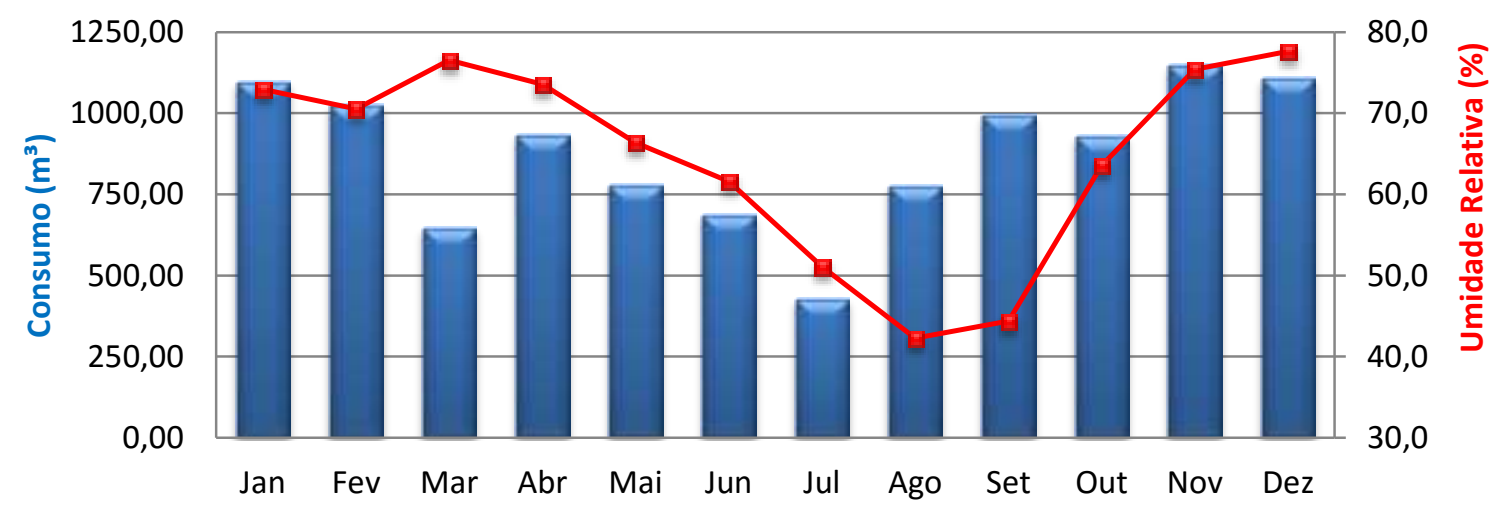

O que se pode observar nos Gráficos 7 e 8 é uma maior linearidade de consumo, com uma certa incoerência de correlação, comparados aos Gráficos 4 e 5, dado que há consumos baixos para umidades relativas e precipitações também baixas. Como forma de buscar uma resposta para essa diferença de análises, foi incorporada, apenas neste caso de consumo sem irrigação, uma análise da variável temperatura, como demonstrada no Gráfico 9, no qual foi exemplificado o comportamento dos Anexos I, II e Restaurante.

O Gráfico 9 mostrou uma maior coerência de comportamento do usuário, quando não considerado o consumo com irrigação. Há uma correlação evidente na maioria dos meses, com um consumo maior nos meses em que há temperaturas ambientes maiores. Cabe destacar 
que há fatores como imprecisão de informações, eventos climáticos atípicos ou vazamentos de difícil identificação que podem alterar dados e dificultar análises de cenários.

Gráfico 9 - Dados de temperatura ambiente comparados com o consumo mensal dos Anexos I, II e Restaurante do TCU em Brasília/DF (período de 2009 a 2014)

\section{Consumo x Temperatura Ambiente Anexos I, II e Restaurante}

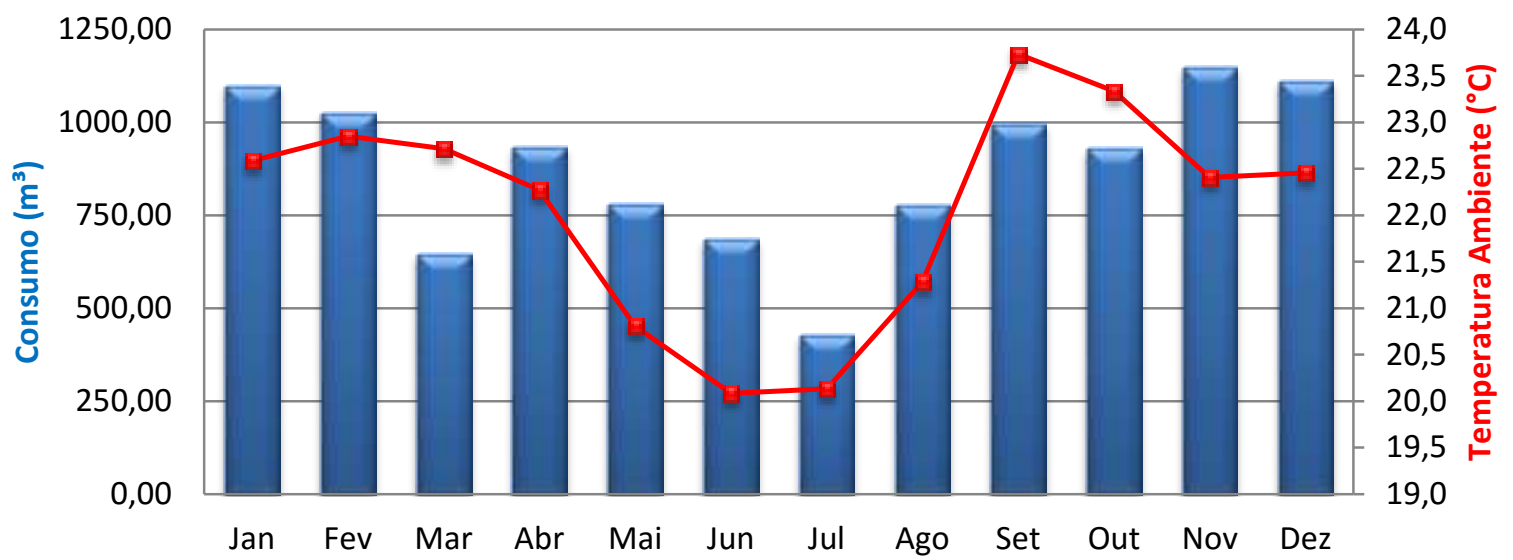

Conforme ANA et al. (2005), valores atípicos do consumo mensal no período histórico, que não se mantenham por mais de um mês, por exemplo, devem ser desconsiderados para o cálculo do indicador de consumo histórico. Como os procedimentos supracitados são constantes e afetam diretamente a média de consumo anual, foi feito um levantamento específico para a definição do impacto do consumo de fatos que distorçam os indicadores.

De acordo com informações da área de gestão da manutenção predial do TCU, eventualmente ocorrem fatos extraordinários no decorrer do ano que sobrecarregam o consumo, como, por exemplo, a necessidade de, ao menos uma vez ao ano, proceder a limpeza do espelho d'água existente no Edifício Sede. O espelho d'água é esgotado integralmente para a remoção de lodo e detritos acumulados ao longo do ano. Outro exemplo é a manutenção da impermeabilização, que esporadicamente demanda o mesmo procedimento.

Ademais, durante o período da última reforma, de 2012 a 2014, partes da área dos espelhos d'água ficaram secos e protegidos, visto que havia risco de queda de detritos provenientes da reforma do Edifício-Sede. Após levantamento dos registros diários das ocorrências atípicas nas leituras dos hidrômetros, foram consolidados na Tabela 11 os respectivos consumos médios de água do espelho d'água esgotados ao longo dos anos, bem como seu impacto no consumo total do conjunto edificado do TCU no mesmo período. O ano de 2014 não foi 
incluído na média, visto que, durante quase o ano inteiro, o espelho d'água estava sem funcionamento, haja vista a obra de reforma do Edifício-Sede. Há que se destacar que não foi calculado o impacto da evaporação de água no espelho, apesar de sua grande área, tendo em vista que tal consumo também está incluído nos números da Tabela 11.

Tabela 11 - Impacto do consumo de água do espelho d'água do Edifício Sede no consumo total do conjunto edificado do TCU em Brasília/DF

\begin{tabular}{|c|c|c|}
\hline Período & Volume $\left(\mathbf{m}^{\mathbf{3}}\right)$ & Impacto no consumo anual (\%) \\
\hline 2011 & 1690 & $9,81 \%$ \\
\hline 2012 & 1281 & $9,28 \%$ \\
\hline 2013 & 647 & $5,19 \%$ \\
\hline Impacto Edifício-Sede & \multirow{2}{*}{3462} & $8,32 \%$ \\
\cline { 1 - 1 } \cline { 3 - 3 } Impacto TCU & & $2,18 \%$ \\
\hline
\end{tabular}

\subsubsection{Sistema hidráulico e manutenção predial}

O TCU não dispõe de edifícios com sistemas de reaproveitamento ou de uso de águas tratadas, mas investe, em seu patrimônio edificado, em sistemas economizadores de água, conforme detalhados mais adiante.

O sistema hidráulico do Edifício Sede segue um padrão normal de edifício em altura, com reservatórios inferiores que atendem o sistema superior por bombeamento. Estas caixas d'água superiores atendem conjuntos sanitários dos pavimentos por gravidade. O sistema de água potável e o de esgotamento sanitário, em todos os edifícios, utilizam prismas verticais como meio para a passagem de colunas de água fria, tubos de queda e tubos de ventilação de esgoto. As derivações ocorrem nas alvenarias e pelos forros.

No que tange às instalações de água potável, os sanitários possuem distribuições diversas das tubulações, com registros comuns a todas as peças do ambiente (Anexos I, II e Restaurante) e também registros separados para vasos sanitários e mictórios (Anexo III e Edifício Sede). Essa separação permite a instalação futura de sistemas de uso de águas cinzas tratadas. A depender da distribuição vertical das colunas de água fria, tal separação pode onerar significativamente custos para a implantação do sistema supracitado.

O atual contrato de manutenção predial do TCU prevê postos de trabalho de técnico e auxiliar em instalações hidrossanitárias prediais, bem como de técnico de instalações de proteção contra incêndio. Todos devem ter conhecimentos técnicos de instalação e manutenção de sistemas, subsistemas e equipamentos hidrossanitários prediais de água fria e quente, esgotamento sanitário, águas pluviais e incêndio. 
Dentre os serviços descritos na manutenção preventiva do conjunto arquitetônico do TCU, há rotinas que abrangem as instalações hidrossanitárias da cozinha, restaurante, sanitários e copas; de detecção, alarme, combate e controle a incêndio; de chuveiros automáticos (sprinklers). São vistoriados equipamentos sanitários, ramais prediais, caixas e bombas de sucção e recalque.

De forma sintética, foram listados, no Quadro 28, os serviços mais afetos a esta pesquisa, demonstrando as ações periódicas da equipe de manutenção predial do TCU. Na visita em que foi analisada a rotina da equipe de manutenção do TCU, foi identificada uma preocupação constante com a economia de água e o permanente diálogo com a equipe gerencial do TCU.

Quadro 28 - Atividades de manutenção hidráulica preventiva no TCU em Brasília/DF

\begin{tabular}{|c|c|}
\hline Frequência & Atividade de manutenção preventiva \\
\hline Diária & $\begin{array}{l}\text { - Verificar a existência de vazamentos, desperdícios ou usos inadequados nas tubulações, } \\
\text { conexões e nos pontos de consumo externos, tais como torneiras, aspersores, válvulas, registros } \\
\text { e alimentação de espelho d'água, efetuando as correções necessárias. } \\
\text { - Verificar a existência de vazamentos em tubulações, registros e torneiras, de entupimentos em } \\
\text { vasos e ralos e a regulagem das válvulas de mictórios e vasos, em todos os sanitários e saná-los. } \\
\text { - Efetuar a leitura dos hidrômetros e verificação de seu estado de conservação e do ramal predial } \\
\text { e verificar o aspecto da água fornecida pela concessionária pública. } \\
\text { - Verificar o nível dos reservatórios. } \\
\text { - Inspecionar as instalações primárias e secundárias dos esgotos. } \\
\text { - Verificar e corrigir, quando necessário, vazamento nas caixas de preventivos fixos contra } \\
\text { incêndio, registros e barriletes. } \\
\text { - Testar o funcionamento das bombas de recalque e inspecionar suas conexões hidráulicas, } \\
\text { válvulas de retenção e funcionamento das boias superiores e inferiores. }\end{array}$ \\
\hline Semanal & $\begin{array}{l}\text { - Verificar a limpeza e estanqueidade dos reservatórios. } \\
\text { - Inspecionar o estado geral do espelho d'água e do seu extravasor. } \\
\text { - Verificar e corrigir, quando necessário, vazamento das válvulas de governo e alarme. } \\
\text { - Verificar se o abastecimento d'água do sistema está normal e a possível existência de válvulas } \\
\text { fechadas ou outras obstruções na tubulação de sprinklers. } \\
\text { - Inspecionar e limpar, se necessário, a caixa d'água elevada do sistema contra incêndio. } \\
\text { - Inspecionar e reparar os medidores de nível, torneira de boia, extravasores, sistema automático } \\
\text { de funcionamento das bombas, registros e válvulas de pé e de retenção. }\end{array}$ \\
\hline Mensal & $\begin{array}{l}\text { - Percorrer todos os pontos de visitas, as caixas de inspeção e de areia, as caixas de gordura, os } \\
\text { bueiros de águas pluviais e os pontos de captação de águas pluviais e limpá-los. } \\
\text { - Verificar e reapertar as juntas de dilatação e conexões de água fria. } \\
\text { - Verificar a rede de água quente, incluindo o funcionamento do(s) aquecedor(es). } \\
\text { - Inspecionar as saídas das tubulações de ventilação e as tubulações imersas, bem como } \\
\text { esguichos, registros, chave de engate rápido e conexões de incêndio. } \\
\text { - Verificar a existência de corrosão em tubulações. }\end{array}$ \\
\hline Trimestral & $\begin{array}{l}\text { - Verificar o funcionamento dos filtros centrais de água e, se necessário, providenciar a } \\
\text { substituição dos elementos filtrantes. } \\
\text { - Providenciar ou acompanhar o esgotamento das caixas de gordura do restaurante. } \\
\text { - Realizar lavagem e secagem adequada das mangueiras de incêndio. }\end{array}$ \\
\hline Semestral & $\begin{array}{l}\text { - Realizar limpeza geral e desinfecção dos reservatórios de água, inferiores e superiores, } \\
\text { respectivamente, com redução gradual do enchimento, para que as perdas sejam minimizadas. } \\
\text { - Submeter as mangueiras a testes hidrostáticos, cuidando para que o procedimento de secagem } \\
\text { seja feito conforme a NBR } 12.779 \text {, normas do CBMDF e orientações do fabricante. }\end{array}$ \\
\hline
\end{tabular}

Fonte: TCU 


\subsubsection{Pontos de consumo}

Os pontos de consumo analisados de forma distinta foram as peças sanitárias, irrigação, limpeza, ar condicionado e cozinha do restaurante, e encontram-se detalhados a seguir.

\subsubsection{Peças sanitárias}

As louças e metais no TCU possuem tipologias por vezes distintas, pois foram fornecidos em momentos diferentes. As características e quantitativos de peças sanitárias do conjunto arquitetônico do TCU em Brasília estão listados na Tabela 12.

As pressões exercidas nos pontos variavam pelo seu posicionamento nos pavimentos e pela altura manométrica. Foram feitas inspeções visuais nos pontos de abastecimento de água potável em todo o conjunto edificado, nos dias úteis, no momento da utilização pelos usuários, bem como nos fins de semana, no momento da manutenção preventiva.

Tabela 12 - Quantitativo de peças sanitárias no conjunto edificado do TCU em Brasília/DF

\begin{tabular}{|c|c|c|c|c|c|c|c|}
\hline Edifício & Vaso & Mictório & Lavatório & Pia & Filtro & Chuveiro & $\begin{array}{c}\text { Ducha } \\
\text { Higiênica }\end{array}$ \\
\hline Ed. Sede & 172 & 25 & 179 & 27 & 18 & 7 & 48 \\
\hline Anexo 1 & 57 & 25 & 60 & 14 & 13 & 5 & 0 \\
\hline Anexo 2 & 66 & 23 & 69 & 12 & 12 & 2 & 0 \\
\hline Anexo 3 & 130 & 45 & 131 & 14 & 12 & 20 & 16 \\
\hline Restaurante & 16 & 5 & 16 & 28 & 0 & 7 & 0 \\
\hline Total & 441 & 123 & 455 & 95 & 55 & 41 & 64 \\
\hline
\end{tabular}

Fonte: TCU

A partir do acompanhamento das vistorias preventivas da equipe de manutenção, foram verificadas as seguintes características:

- Há ocorrências esporádicas de vazamentos visíveis, que são prontamente reparados pela equipe de manutenção, quando das vistorias diárias. Nos casos em que não há material de reposição no estoque da empresa prestadora dos serviços, a alimentação de água é isolada e o equipamento interditado, até que se efetue o reparo;

- Como há verificação diária dos hidrômetros, qualquer oscilação representativa de consumo provoca uma vistoria mais detalhada do sistema. Quando o foco do consumo anormal não é detectável em período diurno e em dias úteis, são realizados testes mais apurados à noite e em fins de semana;

- O estado de conservação das peças sanitárias no TCU em Brasília é excelente, não havendo sinais de vandalismo, com exceção dos mictórios, cujos sensores de presença tinham mau funcionamento em $26 \%$ das peças; 
- Há constante alteração de regulagem de pressão nos registros de gaveta dos banheiros e copas, promovidos por funcionários da equipe de limpeza, quando da lavagem destes ambientes e uso das torneiras de limpeza abaixo das bancadas. Tal ação provoca oscilação na pressão nas torneiras, dificultando sua utilização. Os modelos das torneiras já vêm de fábrica com restritores de vazão que não funcionam adequadamente nesses casos;

- São comuns os casos, em torneiras de copas, de retirada ou quebra deliberada de pulverizadores dos bicos móveis das peças, posto que os usuários, em muitos casos, por costume pessoal, necessitam de maior pressão e volume de água para lavagem de peças. Nesse caso, não houve reposição de peças, tendo em vista a necessidade de uma campanha prévia de conscientização no consumo de água e uso desses equipamentos;

- Os usuários não manifestaram dificuldades com o uso de descargas parciais dos vasos sanitários e dos sensores dos mictórios. O sistema hidromecânico das torneiras provoca algum desconforto em casos de usos específicos, quando se lava o rosto ou se escovam os dentes. Há que se destacar que o uso de sistema de sensores em torneiras, segundo a área de manutenção do TCU, não foi instalado, especialmente devido a seu custo e ao histórico de danos dos sensores.

Concomitante às inspeções visuais, foram realizados levantamentos de vazões na maioria dos pontos d'água do TCU. Como recomendado por ANA et al. (2005), casos pontuais com vazões atípicas, por falha na regulagem dos equipamentos ou por inoperabilidade foram desconsiderados para efeito de cálculo da média das vazões. Nos casos em que não foi possível a aferição dessa vazão, foram considerados os valores fornecidos pelos fabricantes, como nos vasos sanitários.

Como se pode observar na leitura dos dados dos levantamentos das vazões médias das peças sanitárias das áreas molhadas do TCU, consolidados na Tabela 13, as vazões das torneiras das copas foram substancialmente maiores que as de outras peças. Isso se deve em parte ao fato de os pulverizadores de água do próprio modelo da torneira terem sido danificados e retirados. Essa prática, também presenciada na cozinha do restaurante, reduz o tempo de enxágue dos utensílios lavados. A utilização de pressões menores é questão apenas de hábito dos usuários. Mantidas as pressões, pode-se inferir que o tempo de enxágue é o mesmo e o desperdício de água é menor.

Outro dado que foi relativamente diferente dos demais foi a vazão dos chuveiros do Anexo III. Nesse caso, a localização da maioria das peças ( $2^{\circ}$ e $3^{\circ}$ subsolos $)$ levou a pressões altas, 
alterando significativamente as vazões. O restante dos resultados está dentro do esperado e subsidiou os valores de consumo de cada edifício do TCU.

Tabela 13 - Vazões médias das peças sanitárias das áreas molhadas do TCU em Brasília/DF

\begin{tabular}{|c|c|c|c|c|c|c|c|c|c|}
\hline \multirow[b]{2}{*}{ Edifício } & \multicolumn{3}{|c|}{ Torneira do lavatório } & \multicolumn{2}{|c|}{ Torneira da copa } & \multicolumn{2}{|c|}{ Chuveiro } & \multicolumn{2}{|c|}{ Ducha } \\
\hline & $\begin{array}{c}\text { Tempo } \\
\text { médio de } \\
\text { abertura (s) }\end{array}$ & $\begin{array}{l}\text { Volume } \\
\text { (l) }\end{array}$ & $\begin{array}{c}\text { Vazão } \\
(1 / s)\end{array}$ & $\begin{array}{c}\text { Tempo } \\
\text { médio de } \\
\text { abertura (s) }\end{array}$ & $\begin{array}{c}\text { Vazão } \\
(1 / s)\end{array}$ & $\begin{array}{c}\text { Tempo } \\
\text { médio de } \\
\text { abertura (s) }\end{array}$ & $\begin{array}{c}\text { Vazão } \\
(1 / s)\end{array}$ & $\begin{array}{c}\text { Tempo } \\
\text { médio de } \\
\text { abertura (s) }\end{array}$ & $\begin{array}{c}\text { Vazão } \\
(1 / s)\end{array}$ \\
\hline Ed.Sede & 7,63 & 0,93 & 0,123 & 4,31 & 0,248 & 8,27 & 0,126 & 6,30 & 0,153 \\
\hline Anexo I & 4,45 & 0,40 & 0,087 & 4,18 & 0,272 & 8,41 & 0,121 & & \\
\hline Anexo II & 4,25 & 0,32 & 0,077 & 3,92 & 0,260 & 10,05 & 0,110 & & \\
\hline Anexo III & 7,15 & 0,76 & 0,111 & 5,89 & 0,232 & 5,50 & 0,191 & 7,48 & 0,124 \\
\hline Restaurante & 7,41 & 0,83 & 0,112 & 3,83 & 0,380 & 10,24 & 0,110 & & \\
\hline Média TCU & 6,180 & 0,649 & 0,102 & 4,427 & 0,278 & 8,494 & 0,132 & 6,888 & 0,138 \\
\hline
\end{tabular}

Um dado importante foi a regulagem do funcionamento dos sensores de presença dos mictórios nos sanitários. Nas vistorias realizadas nos sanitários foi percebida a falta de calibração dos sensores, pois eram acionados por períodos longos ou com vazões visivelmente menores que as informadas pelo fabricante, que são de 8 litros/minuto. Nesses casos, as vazões aferidas foram desconsideradas.

Pela vistoria feita, é possível concluir que essas variações são provocadas pela manipulação errada dos profissionais da manutenção, dado o pouco espaço para trabalhar e pelo descarregamento de pilhas, conforme mostrado na Foto 12. Essa foto mostra a tubulação de água amassada e a regulagem interna do sistema por sensor. A média de consumo dos edifícios componentes do conjunto edificado do TCU está listada na Tabela 14.

Foto 12 - Mecânica interna dos sensores de presença dos mictórios usados no TCU
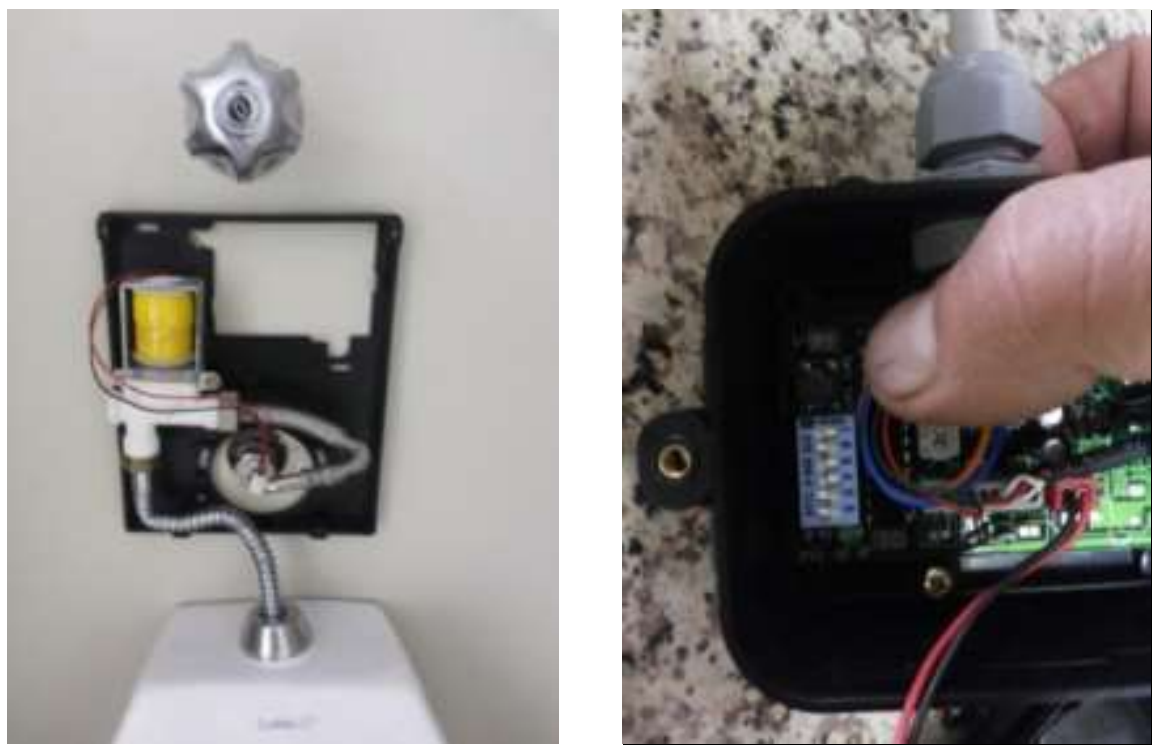

Fonte: TCU 
Tabela 14 - Informações acerca dos mictórios instalados no TCU em Brasília/DF

\begin{tabular}{|c|c|c|c|}
\hline Edifício & $\begin{array}{c}\text { Tempo médio de } \\
\text { fluxo de água (seg) }\end{array}$ & $\begin{array}{c}\text { Percentual com defeito } \\
\text { ou mau funcionamento }\end{array}$ & $\begin{array}{c}\text { Consumo médio por } \\
\text { mictório (litros) }\end{array}$ \\
\hline Ed. Sede & 6,33 & $40,0 \%$ & 0,844 \\
\hline Anexo I & 6,08 & $28,0 \%$ & 0,811 \\
\hline Anexo II & 6,05 & $13,0 \%$ & 0,807 \\
\hline Anexo III & 5,18 & $26,7 \%$ & 0,691 \\
\hline Restaurante & 5,97 & $0,0 \%$ & 0,796 \\
\hline Média & 5,77 & $26,0 \%$ & 0,770 \\
\hline
\end{tabular}

No que tange aos vasos sanitários, não há qualquer diferença entre as peças no conjunto arquitetônico do TCU em Brasília/DF. A válvula de parede é de duplo comando, com consumo de 3 litros de água por acionamento em caso de esgotamento de resíduos líquidos, que foi chamada nesta pesquisa de descarga parcial; e de 6 litros de água em caso de resíduos sólidos, que foi chamada de descarga total, ambos informados pelo fabricante.

\subsubsection{Irrigação}

A área ajardinada do conjunto edificado pesquisado é extensa, e a água utilizada na irrigação dessa área provém da concessionária local. O monitoramento de consumo com irrigação é diário e ocorre com a leitura do hidrômetro geral da concessionária, que, quando deduzidos os gastos com a utilização interna do edifício, resultam no consumo da irrigação. Nos dias em que há reposição da água do espelho d'água, a equipe de manutenção informa essa ação no relatório diário, posto que o consumo aumenta exponencialmente, conforme já tinha sido verificado na análise dos Gráficos 7 e 8 (pp. 154 e 155).

A redução do gasto atual do sistema de irrigação ocorreu em 2008 devido ao alto consumo de água, que passava de $260 \mathrm{~m}^{3}$ por dia. Nessa época foi definido que o sistema de aspersores, composto por pontos fixos que abrangem apenas uma pequena parte da área ajardinada entre o restaurante e o Anexo II e por peças móveis, em que o ajuste é totalmente manual, deveria sofrer uma redução de consumo.

A solução encontrada foi o uso dos dispositivos em um período menor que o anteriormente usado. A redução ocorreu e o consumo diário caiu para $136 \mathrm{~m}^{3}$ por dia. Os dados foram levantados com o apoio da equipe de jardinagem do TCU e estão descritos na Tabela 15. As vazões aferidas nos pontos do sistema fixo e nos locais de fixação do sistema móvel, consideradas nos cálculos de consumo após 2008, constam da Tabela 18.

\footnotetext{
${ }^{17}$ Foram considerados desregulados os mictórios que não lançavam o jato de água para limpeza ou os que o lançavam por mais de dez segundos.

${ }^{18}$ Considerada a vazão de 8 litros/minuto, informada pelo fabricante.
} 
Tabela 15 - Consumo de água do sistema de irrigação do TCU em Brasília/DF

\begin{tabular}{|c|c|c|c|c|c|c|}
\hline Período & $\begin{array}{c}\text { Tipo de } \\
\text { aspersor }\end{array}$ & Quantidade & $\begin{array}{c}\text { Tempo de } \\
\text { utilização } \\
\text { (min) }\end{array}$ & $\begin{array}{c}\text { Consumo } \\
\text { diário por } \\
\text { aspersor }\left(\mathbf{m}^{3}\right)\end{array}$ & $\begin{array}{c}\text { Consumo diário } \\
\text { total }\left(\mathbf{m}^{3}\right)\end{array}$ & $\begin{array}{c}\text { Consumo } \\
\text { mensal total } \\
\left(\mathbf{m}^{\mathbf{3}}\right) \\
\end{array}$ \\
\hline \multirow{3}{*}{$\begin{array}{l}\text { Até } \\
2008\end{array}$} & Móvel & 16 & 420 & 6,00 & 95,96 & $2.015,19$ \\
\hline & Fixo & 202 & 40 & 0,84 & 170,50 & $3.580,59$ \\
\hline & \multicolumn{4}{|c|}{ Total } & 266,47 & $5.595,78$ \\
\hline \multirow{3}{*}{$\begin{array}{l}\text { Após } \\
2008\end{array}$} & Móvel & 12 & 180 & 5,18 & 62,16 & $1.305,40$ \\
\hline & Fixo & 202 & 30 & 0,63 & 69,64 & $1.462,37$ \\
\hline & \multicolumn{4}{|c|}{ Total } & 131,80 & $2.767,76$ \\
\hline & & & & & Redução após 2008 & $50,54 \%$ \\
\hline
\end{tabular}

Também foi verificada a representatividade no consumo mensal da irrigação em cada edifício do conjunto arquitetônico do TCU, conforme mostrado na Tabela 16. A representatividade da estimativa foi baseada na correlação do volume de chuvas ao longo dos meses, como se verifica na Tabela 17.

Tabela 16 - Proporcionalidade do consumo de água ao longo do ano e cálculo de indicador de consumo de água com irrigação no TCU em Brasília/DF

\begin{tabular}{|c|c|c|c|c|c|}
\hline & \multicolumn{2}{|c|}{$\mathbf{T C U}$} & \multicolumn{3}{|c|}{ Distribuição de consumo entre os edifícios } \\
\hline & $\begin{array}{c}\text { Consumo } \\
\text { diário total } \\
\left(\mathbf{m}^{3}\right)\end{array}$ & $\begin{array}{c}\text { Consumo } \\
\text { mensal } \\
\text { total }\left(\mathbf{m}^{3}\right) \\
\end{array}$ & Edifício-Sede & $\begin{array}{c}\text { Anexos I, II e } \\
\text { Restaurante }\end{array}$ & Anexo III \\
\hline $\begin{array}{l}\text { Novembro/dezembro ( }+ \text { chuvoso) } \\
\text { acima de } 250 \mathrm{~mm} \text { médios mensais }\end{array}$ & \multicolumn{2}{|c|}{ Sem consumo } & \multicolumn{3}{|c|}{ Sem consumo } \\
\hline $\begin{array}{l}\text { Março/abril/outubro (chuvoso) } \\
\text { entre } 200 \text { mm a } 250 \text { mm médios mensais }\end{array}$ & 32,95 & 691,94 & 163,17 & 398,23 & 130,54 \\
\hline $\begin{array}{l}\text { Janeiro/fevereiro (- chuvoso) } \\
\text { entre } 50 \mathrm{~mm} \text { a } 199 \mathrm{~mm} \text { médios mensais }\end{array}$ & 98,85 & $2.075,82$ & 489,52 & $1.194,68$ & 391,62 \\
\hline $\begin{array}{l}\text { Maio a setembro (seco) } \\
\text { até } 49 \mathrm{~mm} \text { médios mensais }\end{array}$ & 131,80 & $2.767,76$ & 652,70 & $1.592,91$ & 522,16 \\
\hline $\begin{array}{l}\text { Indicador de consumo } \\
\left.\text { (litros } / \mathrm{m}^{2} / \mathrm{dia}\right)\end{array}$ & \multicolumn{2}{|c|}{1,28} & 0,95 & 1,70 & 0,96 \\
\hline
\end{tabular}

Tabela 17 - Representatividade do consumo da irrigação no consumo total de água no TCU em Brasília/DF

\begin{tabular}{|c|c|c|c|}
\hline Edifício & $\begin{array}{c}\text { Consumo mensal } \\
\text { médio total }\left(\mathbf{m}^{\mathbf{3}}\right)\end{array}$ & $\begin{array}{c}\text { Consumo mensal } \\
\text { médio da irrigação } \\
\left(\mathbf{m}^{3}\right)\end{array}$ & Representatividade \\
\hline Edifício-Sede & $1.107,51$ & 394,34 & $35,61 \%$ \\
\hline Anexos I, II e Restaurante & $2.638,65$ & 962,38 & $36,47 \%$ \\
\hline Anexo III & 874,08 & 315,47 & $36,09 \%$ \\
\hline
\end{tabular}

Ressalte-se que está em fase de implantação uma nova solução para esses jardins, de forma automatizada, que garantirá uma eficiência na manutenção, redução de equipe de manutenção e menor gasto com água. A previsão de implantação desse novo sistema é para o ano de 2016. 
Apenas como indicador de referência, a rega de jardim deve representar um consumo diário máximo igual a 1,5 litros $/ \mathrm{m}^{2}$ (GHISI, 2004). Como a área total de gramados e jardins do TCU é de 54,5 mil $\mathrm{m}^{2}$, o consumo do TCU ficou abaixo dessa referência, com o consumo de 1,28 litros $/ \mathrm{m}^{2} / \mathrm{dia}$.

Tabela 18 - Representatividade do consumo da irrigação de cada edifício no consumo total de água no TCU em Brasília/DF

\begin{tabular}{|c|c|c|c|c|}
\cline { 2 - 4 } \multicolumn{1}{c|}{} & \multicolumn{3}{c|}{ Sistema móvel } & \multirow{2}{*}{$\begin{array}{c}\text { Sistema } \\
\text { fixo }\end{array}$} \\
\cline { 2 - 4 } \multicolumn{1}{c|}{ Sede } & $\begin{array}{c}\text { Anexos I, II e } \\
\text { Restaurante }\end{array}$ & Anexo III & 2,84 \\
\hline Tempo médio (s/l) & 2,17 & 2,27 & 1,95 & 0,512 \\
\hline Vazão média (1/s) & 0,461 & 0,442 & 0,352 \\
\hline Vazão TCU (1/s) & \multicolumn{3}{c}{0,480} & \\
\hline
\end{tabular}

Apesar de o indicador levantado sugerir eficiência do sistema, é evidente na vistoria realizada que o consumo não parece eficiente, porque o sistema não é automatizado, requerendo uma quantidade de mão de obra desnecessária para seu funcionamento. Ademais, os funcionários da equipe de jardinagem, apesar de inúmeros avisos dos funcionários da manutenção e dos gestores do contrato do TCU, continuam com pouca consciência do desperdício no seu uso, como se depreende da Foto 13, de agosto de 2015.

Atualmente, o TCU terceiriza a equipe de jardinagem, que tem 15 postos de trabalho. A rotina dos funcionários se resume à rega de jardins externos, dos espelhos d'água e de vasos de plantas das salas administrativas. A equipe também realiza poda de plantas e cuida do viveiro de mudas para reposição. Também há queixas de falta de cuidado desses profissionais nas regas dentro dos espelhos d'água, gerando rompimento de camadas de impermeabilização e, por conseguinte, provocando vazamentos de difícil identificação pela manutenção.

Foto 13 - Exemplo de desperdício de água no TCU em Brasília/DF

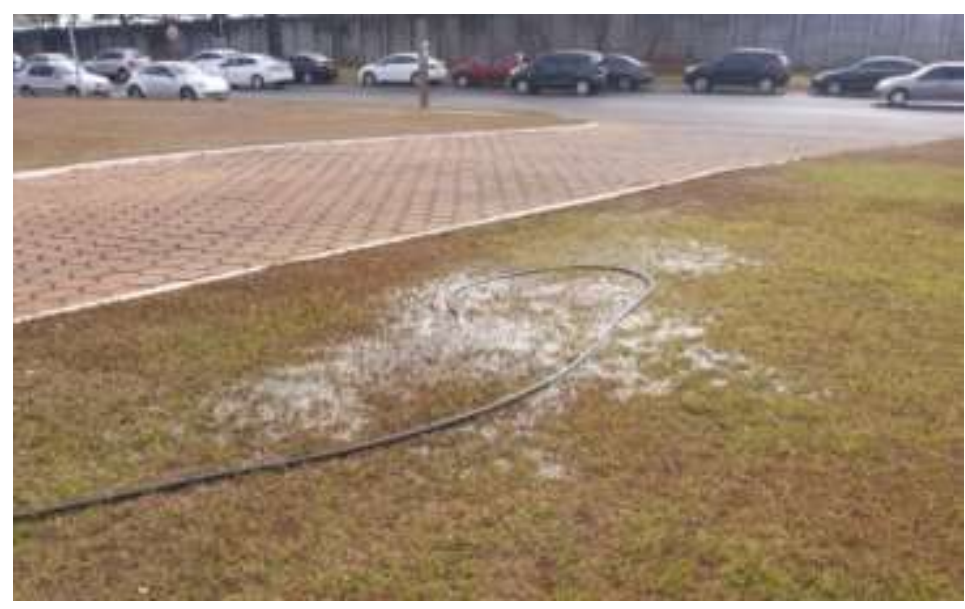

Fonte: TCU 


\subsubsection{Limpeza}

A limpeza dos edifícios do TCU é, em parte, realizada com auxílio de água. Conforme informações do responsável pelo setor, a limpeza diária de pisos e de móveis é feita com uso de baldes de doze litros, diariamente, em todas as salas administrativas dos edifícios, na proporção de um balde para cada $20 \mathrm{~m}^{2}$ de área de escritórios. No caso de limpeza de sanitários, sejam eles coletivos ou privativos, o trabalho é feito em dias intercalados, com uso de um a dois baldes para cada ambiente.

As áreas comuns utilizam de um a dois baldes por andar por dia para a limpeza, posto que o acabamento é em piso vinílico. A única exceção ocorre no Edifício-Sede, onde as circulações dos pavimentos das autoridades são revestidas com carpete. Com posse das áreas administrativas e de circulação de cada andar de cada edifício do TCU, assim como o número de sanitários coletivos e privativos, foi possível o cálculo final de consumo de água.

Há vários casos de consumo esporádico no conjunto edificado do TCU. As áreas externas próximas às entradas dos edifícios, com acabamento em mármore ou granito, semanalmente recebem uma limpeza, na qual são consumidos cerca de 1.000 litros de água. As esquadrias, por sua vez, são limpas ao menos quatro vezes por ano, com utilização de cadeira suspensa. Nesse caso, de acordo com o setor de limpeza do TCU, o gasto de água é próximo a 15 litros $/ \mathrm{m}^{2}$. Com os dados da área de esquadrias, foi possível o cálculo desse consumo. A Tabela 19 detalha o consumo de água com limpeza no TCU em todos seus edifícios em Brasília.

Por outro lado, consumos considerados excessivos foram ajustados ou extintos. No caso da lavagem de veículos oficiais, foi cedida uma área para a exploração de uma empresa contratada, que também atendia veículos particulares. A empresa, após dois anos de contrato, desistiu de renovar o contrato em 2014, pois consumia cerca de 2.500 litros de água por dia e o gasto não cobria os custos de pessoal e mão de obra. Está em curso neste ano a contratação de limpeza ecológica de veículos, que, pelo edital publicado, não poderá gastar mais que dois litros de água por lavagem.

Cabe salientar que um consumo significativo de água nas contas mensais ocorre quando é necessária a limpeza do espelho d'água que circunda o Edifício-Sede do TCU. Com $6.500 \mathrm{~m}^{2}$ de área e $3.280 \mathrm{~m}^{3}$ de volume, esse reservatório de água, quando esgotado, impacta significativamente no consumo mensal. A frequência é de uma limpeza ao ano, sempre no 
período seco do ano, quando não ocorrem eventos excepcionais. Apenas como exemplo, no ano de 2015, foram necessários mais dois esgotamentos para reparos na impermeabilização daquele local. O impacto desse consumo já está contemplado na Tabela 11, não sendo, portanto, incluídos os dados na Tabela 19.

Tabela 19 - Consumo consolidado de limpeza no conjunto edificado do TCU em Brasília/DF

\begin{tabular}{|c|c|c|c|c|c|c|}
\hline \multirow[b]{2}{*}{ Setor } & Edifício-Sede & Anexo I & Anexo II & Anexo III & Restaurante & \multirow{2}{*}{\begin{tabular}{|c} 
Consumo \\
total por \\
setor \\
$(1 / \mathrm{mês})$ \\
\end{tabular}} \\
\hline & \multicolumn{5}{|c|}{$\begin{array}{l}\text { Consumo total (l/mês) } \\
\text { Parâmetro de consumo }\end{array}$} & \\
\hline $\begin{array}{l}\text { Corredores } \\
\text { internos }\end{array}$ & $\begin{array}{c}\mathbf{6 1 2} \\
12 \text { litros/dia/pav } \\
(1 \times \text { dia }) \\
\end{array}$ & $\begin{array}{c}\mathbf{2 . 7 5 4} \\
18 \text { litros/dia/pav } \\
(1 \times \text { dia }) \\
\end{array}$ & $\begin{array}{c}\mathbf{3 . 6 7 2} \\
18 \text { litros/dia/pav } \\
(1 \times \mathrm{dia}) \\
\end{array}$ & $\begin{array}{c}\mathbf{3 . 6 7 2} \\
18 \text { litros/dia/pav } \\
(1 \times \text { dia }) \\
\end{array}$ & $\begin{array}{c}1.224 \\
24 \text { litros/dia/pav } \\
(1 \times \text { dia }) \\
\end{array}$ & 11.934 \\
\hline $\begin{array}{l}\text { Corredores } \\
\text { externos } \\
\text { (varandas } \\
\text { perimetrais) }\end{array}$ & $\begin{array}{c}\mathbf{6 0 . 7 5 0} \\
1.500 \text { litros/pav } \\
(2 \times \text { semana })\end{array}$ & & & & & 60.750 \\
\hline $\begin{array}{c}\text { Áreas } \\
\text { Administrativas }\end{array}$ & $\begin{array}{c}\mathbf{1 7 9 . 0 2 7} \\
12 \text { litros/dia } \\
\left(\text { cada } 20 \mathrm{~m}^{2}\right) \\
\end{array}$ & \begin{tabular}{|c|}
$\mathbf{8 4 . 1 7 8}$ \\
12 litros/dia \\
$\left(\right.$ (cada $\left.20 \mathrm{~m}^{2}\right)$ \\
\end{tabular} & $\begin{array}{c}\mathbf{1 0 9 . 8 8 3} \\
12 \text { litros/dia } \\
\left(\text { cada } 20 \mathrm{~m}^{2}\right) \\
\end{array}$ & $\begin{array}{c}\mathbf{1 3 1 . 0 2 1} \\
12 \text { litros/dia } \\
\left(\text { cada } 20 \mathrm{~m}^{2}\right) \\
\end{array}$ & $\begin{array}{c}27.294 \\
60 \text { litros/dia } \\
\left(\text { cada } 20 \mathrm{~m}^{2}\right) \\
\end{array}$ & 531.404 \\
\hline $\begin{array}{c}\text { Sanitários, } \\
\text { copas e } \\
\text { vestiários }\end{array}$ & $\begin{array}{c}\mathbf{1 9 . 8 9 0} \\
30 \text { litros/dia/amb }\end{array}$ & $\begin{array}{c}\mathbf{1 8 . 3 6 0} \\
30 \text { litros/dia/amb }\end{array}$ & $\begin{array}{c}\mathbf{1 8 . 3 6 0} \\
30 \text { litros/dia/amb }\end{array}$ & $\begin{array}{c}\mathbf{2 1 . 4 2 0} \\
30 \text { litros/dia/amb }\end{array}$ & $\begin{array}{c}\mathbf{4 . 5 9 0} \\
30 \text { litros/dia/amb }\end{array}$ & 82.620 \\
\hline $\begin{array}{l}\text { Sanitários } \\
\text { privativos }\end{array}$ & $\begin{array}{c}\mathbf{5 1 . 6 3 8} \\
15 \text { litros/dia/amb }\end{array}$ & $\begin{array}{c}2.295 \\
15 \text { litros/dia/amb }\end{array}$ & $\begin{array}{c}\mathbf{7 . 6 5 0} \\
15 \text { litros/dia/amb }\end{array}$ & $\begin{array}{c}\mathbf{6 . 5 0 3} \\
15 \text { litros/dia/amb }\end{array}$ & & 34.920 \\
\hline Áreas externas & $\begin{array}{c}\mathbf{4 . 5 0 0} \\
1.000 \text { litros/semana }\end{array}$ & \begin{tabular}{|c|}
$\mathbf{4 . 5 0 0}$ \\
1.000 litros/semana
\end{tabular} & $\begin{array}{c}\mathbf{4 . 5 0 0} \\
1.000 \text { litros/semana }\end{array}$ & $\begin{array}{c}\mathbf{4 . 5 0 0} \\
1.000 \text { litros/semana }\end{array}$ & & 22.500 \\
\hline Fachadas & $\begin{array}{c}1.866 \\
1,5 \text { litros } / \mathrm{m}^{2} \\
(4 \mathrm{x} \text { ano })\end{array}$ & $\begin{array}{c}2.012 \\
2 \text { litros } / \mathrm{m}^{2} \\
(4 \mathrm{x} \text { ano })\end{array}$ & $\begin{array}{c}2.565 \\
2 \text { litros/m² } \\
(4 \mathrm{x} \text { ano })\end{array}$ & $\begin{array}{c}2.915 \\
2 \text { litros/m² } \\
(4 \mathrm{x} \text { ano })\end{array}$ & $\begin{array}{c}1.343 \\
2 \text { litros } / \mathrm{m}^{2} \\
(4 \mathrm{x} \text { ano })\end{array}$ & 10.700 \\
\hline $\begin{array}{l}\text { Lavagem } \\
\text { subsolos }\end{array}$ & $\begin{array}{c}\mathbf{4 . 5 0 0} \\
1.000 \mathrm{lt} / \mathrm{pav} / \mathrm{mês}\end{array}$ & $\begin{array}{c}\mathbf{4 . 5 0 0} \\
1.000 \mathrm{lt} / \mathrm{pav} / \mathrm{semana} \\
\end{array}$ & $\begin{array}{c}\mathbf{4 . 5 0 0} \\
1.000 \mathrm{lt} / \mathrm{pav} / \mathrm{semana}\end{array}$ & $\begin{array}{c}\mathbf{9 . 0 0 0} \\
1.000 \mathrm{lt} / \mathrm{pav} / \mathrm{semana}\end{array}$ & & 22.500 \\
\hline $\begin{array}{l}\text { Lavagem } \\
\text { veículos }\end{array}$ & & & & $\begin{array}{c}\mathbf{7 3 . 8 4 2} \\
\text { 2.461 litros/dia } \\
\text { (até dez/2013) }\end{array}$ & & 73.842 \\
\hline $\begin{array}{l}\text { Consumo total } \\
\text { por edifício } \\
(1 / \mathrm{mês})\end{array}$ & 322.783 & 118.600 & 151.130 & 252.872 & 34.451 & 879.835 \\
\hline
\end{tabular}

\subsubsection{Cozinha do restaurante}

O restaurante do TCU, pelo seu uso completamente distinto dos outros edifícios, foi analisado separadamente. Como na literatura nacional e internacional não foi encontrada qualquer menção à exclusão de área de sanitários e vestiários nos restaurantes para efeito de cálculo de indicadores, esses usos foram incluídos no cálculo desta pesquisa. O gasto de água, portanto, concentra-se no preparo dos alimentos, na cocção, na lavagem de talheres, louças e utensílios de cozinha, na limpeza de pisos e na higiene pessoal dos empregados e usuários dos restaurantes. 
Na visita à cozinha industrial, verificou-se que os gastos com água ocorrem de forma aleatória em alguns pontos, a depender do cardápio proposto. Como exemplo, se gasta mais água na lavagem de panelas e no preparo de alimentos que têm volumes maiores. Outro exemplo é a lavagem de folhagens, que exigem mais tempo que outros itens de saladas, gerando um gasto maior de água. Outra característica que chamou a atenção foi a retirada deliberada de pulverizadores dos bicos de algumas torneiras. Tal artifício foi necessário, segundo depoimento de funcionários, para aumentar a vazão e reduzir o tempo para encher vasilhas e panelas.

Há também características de saúde que são diferenciadas, pois a higiene é fator fundamental para a segurança alimentar. Dessa forma, a rotina de lavagem dos ambientes é diária, com atenção especial para a área de cocção, bancadas de aço inox, pisos e equipamentos. As paredes recebem uma lavagem mais aprofundada uma vez por semana.

É necessário registrar que o atual sistema de contrato do TCU com a empresa prestadora de serviços do restaurante não prevê o pagamento de água e energia do contratado. Em contratos anteriores, havia a cobrança em separado, sendo necessária à época a instalação de hidrômetro separado para essa leitura. Não obstante a falta de leituras de consumo no contrato atual, o hidrômetro continua funcionando perfeitamente.

Para se obter o consumo de água do restaurante, foi feita uma medição diária nesse hidrômetro por uma semana, no mês de julho de 2015, quando ocorreram férias de muitos usuários do local, e agosto de 2015, período de frequência normal do restaurante. Os dados estão consolidados na Tabela 20. Percebe-se que a diferença de consumo entre os meses medidos foi de $3,35 \%$ e considerada pouco expressiva, fato que indica pouco impacto das férias escolares de julho na rotatividade de consumidores no restaurante do TCU.

Segundo informações do prestador de serviços do TCU, diariamente, entre segunda-feira e quarta-feira, 700 refeições são servidas. Nas quintas-feiras e sextas-feiras esse número sobe para 800 refeições. Nos meses de julho, dezembro e janeiro, há redução de $20 \%$ no número de refeições. Foi definido, portanto, nesta pesquisa, o valor de 700 refeições/dia. Cabe esclarecer que a área de alimentação do restaurante comporta 400 pessoas sentadas. Dessa forma, outro indicador do TCU que pode ser utilizado em pesquisas, além dos citados na Tabela 20, é o de 1,75 refeição/assento/dia. 
É de se destacar a consideração de variáveis na Tabela 20 que não foram encontradas na literatura brasileira pesquisada, como o número de assentos e o número de funcionários do restaurante. Tais variáveis estão presentes nas pesquisas de Waggett \& Arotsky (2006), Dziegielewski (2000) e Fyfe et al. (2012). Dessa forma, espera-se que esses números sejam referências para outros trabalhos de consumo de restaurantes em edifícios comerciais e públicos.

Tabela 20 - Consumo de água no restaurante do TCU em Brasília/DF

\begin{tabular}{|c|c|c|c|c|c|c|}
\hline \multirow[b]{2}{*}{ Data } & \multirow[b]{2}{*}{$\begin{array}{l}\text { Dia da } \\
\text { leitura }\end{array}$} & \multirow[b]{2}{*}{$\begin{array}{c}\text { Dia do } \\
\text { consumo }\end{array}$} & \multirow[b]{2}{*}{$\begin{array}{c}\text { Consumo } \\
\left(\mathbf{m}^{3}\right)\end{array}$} & \multicolumn{3}{|c|}{ Indicadores } \\
\hline & & & & $\begin{array}{c}\text { Consumo por } \\
\text { produção } \\
\text { (l/refeição/dia) }\end{array}$ & $\begin{array}{l}\text { Consumo por } \\
\text { capacidade } \\
\text { (l/assento/dia) }\end{array}$ & \begin{tabular}{|c|} 
Consumo por \\
mão de obra \\
(l/empregado/dia)
\end{tabular} \\
\hline $30 / 06 / 2015$ & $3^{a}$ & $2^{a}$ & 33 & 47,14 & 88,00 & $1.000,00$ \\
\hline $01 / 07 / 2015$ & $4^{a}$ & $3^{\mathrm{a}}$ & 36 & 51,43 & 96,00 & $1.090,91$ \\
\hline $02 / 07 / 2015$ & $5^{a}$ & $4^{a}$ & 39 & 55,71 & 104,00 & $1.181,82$ \\
\hline 03/07/2015 & $6^{\mathrm{a}}$ & $5^{a}$ & 31 & 38,75 & 82,67 & 939,39 \\
\hline $06 / 07 / 2015$ & $2^{\mathrm{a}}$ & $6^{\mathrm{a}}$ & 36 & 45,00 & 96,00 & $1.090,91$ \\
\hline $07 / 07 / 2015$ & $3^{\mathrm{a}}$ & $2^{a}$ & 29 & 41,43 & 77,33 & 878,79 \\
\hline $08 / 07 / 2015$ & $4^{a}$ & $3^{a}$ & 32 & 45,71 & 85,33 & 969,70 \\
\hline \multicolumn{3}{|c|}{ Média de consumo em julho } & 33,71 & 46,45 & 89,90 & $1.021,65$ \\
\hline $12 / 08 / 2015$ & $4^{\mathrm{a}}$ & $3^{a}$ & 32 & 45,71 & 85,33 & 969,70 \\
\hline $13 / 08 / 2015$ & $5^{a}$ & $4^{a}$ & 33 & 47,14 & 88,00 & $1.000,00$ \\
\hline $14 / 08 / 2015$ & $6^{\mathrm{a}}$ & $5^{a}$ & 31 & 44,29 & 82,67 & 939,39 \\
\hline $17 / 08 / 2015$ & $2^{\mathrm{a}}$ & $6^{\mathrm{a}}$ & 53 & 66,25 & 141,33 & $1.606,06$ \\
\hline $18 / 08 / 2015$ & $3^{\mathrm{a}}$ & $2^{a}$ & 33 & 41,25 & 88,00 & $1.000,00$ \\
\hline $20 / 08 / 2015$ & $5^{\mathrm{a}}$ & $4^{\mathrm{a}}$ & 34 & 48,57 & 90,67 & $1.030,30$ \\
\hline \multicolumn{3}{|c|}{ Média de consumo em agosto } & 35,14 & 48,01 & 93,71 & $1.064,94$ \\
\hline \multicolumn{3}{|c|}{ Diferença julho/agosto } & $3,35 \%$ & & & \\
\hline \multicolumn{3}{|c|}{ Consumo/indicadores auditados } & 34,79 & 47,62 & 92,76 & $1.054,11$ \\
\hline
\end{tabular}

Considerando os valores levantados nos hidrômetros do restaurante, conforme a Tabela 20, o indicador encontrado no TCU foi de 47,62 litros/refeição/dia, que é superior ao recomendado pela SABESP (2010), de 20 a 30 litros/refeição/dia, indicando a necessidade de ajustes no consumo dentro da cozinha do restaurante do TCU. Por outro lado, quando comparados com padrões internacionais, conforme exemplificado na Tabela 7, conclui-se que o gasto de água no restaurante do TCU em Brasília está dentro de padrões adequados de consumo.

Não obstante a simulação de outras variáveis, parece razoável concluir que a melhor delas ainda é o número de refeições servidas em um restaurante, pela falta de outros dados nacionais, especialmente quando analisadas em conjunto com outros edifícios de funções distintas. 


\subsubsection{Ar condicionado}

Outro sistema que utiliza água para seu funcionamento é o de condicionamento de ar do Edifício-Sede e do restaurante do TCU. É importante alertar que o restante do conjunto edificado do TCU possui sistemas do tipo Variable Refrigerant Flow (VRF), em que não há utilização de água.

O sistema do restaurante é baseado em unidade resfriadora de líquido de condensação a ar e se perde quantidade mínima de água por razão de vazamentos e eventuais purgas. O sistema que atende ao Edifício-Sede é baseado em unidade resfriadora de líquido de condensação a água. Nesse caso há também, além das supracitadas, perdas por evaporação da água nas duas torres de condensação e por arraste do ventilador. Segundo o fabricante dos equipamentos, a perda é de 1,6 m³/h em cada uma das torres, em regime máximo de operação.

Vale ressaltar que há variadores de frequência que controlam a operação dessas torres, ajustando sua velocidade (ou mesmo seu funcionamento) a depender da umidade e da temperatura externa. Em dias mais secos e quentes, as duas torres tendem a operar em seu limite, consumindo o valor acima apontado. Em dias de chuva e frio, o consumo é irrisório, uma vez que a água da chuva ajuda a completar o nível das torres e reduz o uso dos ventiladores.

Em dias ordinários, conforme informações da área de manutenção do TCU, o sistema opera com apenas uma torre, em aproximadamente $50 \%$ de sua potência máxima. Dessa forma, adotando-se o parâmetro acima, estima-se que, em média, se consuma $0,8 \mathrm{~m} / \mathrm{h}$. Considerando que a máquina desse sistema de climatização opera 12 horas por dia, 21 dias por mês, o consumo médio total das torres é de aproximadamente $113,4 \mathrm{~m}^{3} / \mathrm{mês}$. Para efeito de consumo de água, foram feitas as mesmas ponderações do sistema de irrigação, com pesos para os consumos dos meses de chuva, conforme a Tabela 21.

No caso do restaurante, as perdas no sistema apenas ocorrem em situações excepcionais, como vazamentos ou purgas planejadas pela equipe de manutenção. Ocorre que tais fatos são tão raros que há dificuldade em se precisar um valor. De acordo com a manutenção do TCU, é certo que, no caso de não haver nenhuma falha séria do sistema, o consumo de água não superaria 1.000 litros/ano. Por essa razão, tal volume foi desprezado para fins de estimativa. 
Como contribuição a outras pesquisas que envolvam consumo de água e indicadores relativos aos sistemas de refrigeração, foi calculado o respectivo indicador de consumo na Tabela 23, cuja unidade de medida é em litros/área condicionada/dia.

Tabela 21 - Consumo de água no sistema de ar condicionado do TCU em Brasília/DF

\begin{tabular}{|c|c|c|}
\cline { 2 - 3 } \multicolumn{1}{c|}{} & $\begin{array}{c}\text { Consumo diário } \\
\text { total }\left(\mathbf{m}^{3}\right)\end{array}$ & $\begin{array}{c}\text { Consumo mensal } \\
\text { total }\left(\mathbf{m}^{3}\right)\end{array}$ \\
\hline $\begin{array}{c}\text { Novembro e dezembro (muito chuvoso) } \\
\text { acima de 250 mm médios mensais }\end{array}$ & \multicolumn{2}{|c|}{ Sem consumo } \\
\hline $\begin{array}{c}\text { Março/abril/outubro (chuvoso) } \\
\text { entre 200 mm a 250 mm médios mensais }\end{array}$ & 2,40 & \multirow{2}{*}{50,40} \\
\hline $\begin{array}{c}\text { Janeiro e fevereiro (pouco chuvoso) } \\
\text { entre 50 mm a 199 mm médios mensais }\end{array}$ & 4,80 & \multirow{2}{*}{100,80} \\
\hline $\begin{array}{c}\text { Maio/setembro (seco) } \\
\text { até 49 mm médios mensais }\end{array}$ & 9,60 & \multirow{2}{*}{201,60} \\
\hline Consumo mensal médio (litros) & $113.400,00$ & \multirow{2}{*}{} \\
\hline Indicador de consumo (litros/área condicionada/dia) & 0,461 & \multicolumn{1}{|c}{} \\
\cline { 1 - 2 } &
\end{tabular}

\subsubsection{Qualidade da água para consumo}

Historicamente, o TCU tem resistência em implantar um sistema mais sustentável em relação à água potável para consumo direto dos usuários. Ainda há uso de garrafas plásticas de $500 \mathrm{ml}$ de água mineral para esse fim. Nesse caso, além do uso do plástico na fabricação das garrafas, material sabidamente de difícil decomposição, há evidente desperdício de água, visto que muitos usuários bebem apenas parte do líquido e jogam o restante fora. Cabe esclarecer que, concomitantemente a esse uso, são realizados testes laboratoriais de qualidade da água, que sempre comprovaram sua adequação aos requisitos mínimos de potabilidade do Ministério da Saúde.

Como forma de incentivar o uso mais sustentável desse insumo, foram distribuídos copos de vidro e squeezes para os servidores, bem como instalados filtros de parede e assinado contrato de manutenção desses filtros, para que a troca das peças ocorra dentro do prazo prescrito pelos fabricantes. Mesmo assim, não houve mudança de postura dos gerentes, pois ainda persiste o fornecimento de garrafas plásticas.

Mesmo enfrentando resistências, no mesmo questionário aplicado para fins de aferição dos usos finais da água, chegou a ser cogitado que os respondentes se posicionassem sobre uma futura descontinuidade do contrato de fornecimento de água mineral em garrafas plásticas. Em vez disso, a administração do TCU fez pesquisa rápida com outros órgãos e levantou que a migração para filtros de parede ou galões já ocorreu na totalidade dos órgãos pesquisados. 
Na pesquisa enviada também houve muitas manifestações apoiando a extinção das garrafas. Dessa forma, parece evidente que a mudança de paradigma no TCU ocorrerá brevemente.

\subsection{Cálculo de indicadores de consumo}

Cabe inicialmente informar que as análises de indicadores de uso de água em restaurantes e em sistemas de irrigação e ar condicionado não estão presentes neste item, pois já foram tratadas nos itens 5.1.4.2, 5.1.4.4 e 5.1.4.5, respectivamente. A nomenclatura utilizada corretamente em pesquisas que envolvem o cálculo de indicadores de consumo é fundamental. Para tanto, serão apontadas as definições de termos que se vinculam ao tema e são empregados erroneamente no meio acadêmico: variável, parâmetro e indicador.

Conforme define Sant'Ana (2015), variável é 'um elemento, característica ou fator suscetível a variações ou alterações”. No caso do consumo de água, são elementos que afetam a maneira pela qual a água é usada em edificações. No caso da presente pesquisa, além da tipologia da edificação, as variáveis que foram consideradas, entre outras, foram o volume de água consumido, a população, áreas construídas diversas e o número de refeições do restaurante.

Quanto aos parâmetros, o mesmo autor define que são "fatores mensuráveis, numéricos ou de outro formato, pelos quais diferentes variáveis podem ser comparadas”. Em consumo de água, eles são utilizados para comparar o desempenho hidráulico de edificações. Nesta pesquisa respeitou-se a recomendação de ANA et al. (2005) em relação ao uso do parâmetro de litros/pessoa/dia para o consumo de água em edificações.

Além do parâmetro acima citado, buscaram-se referências brasileiras e internacionais acerca deste assunto para confirmar se realmente era o mais indicado. Além da recomendação de ANA et al. (2005), que o define como a relação entre o volume de água consumido em um determinado período, denominado período histórico, e o número de agentes consumidores nesse mesmo período, foram considerados outros parâmetros, adotados em âmbito internacional e que, em pesquisas subsequentes, podem ser verificados quanto às suas representatividades.

Ocorre que, ainda segundo ANA et al. (2005), aspectos físicos como o lay-out da edificação, arranjo estrutural e sistemas prediais, incluindo disponibilidade de medidores e condições de operação e manutenção, tornam-se fundamentais para a obtenção de indicadores confiáveis. Parece assim evidente que o indicador recomendado de litros/pessoa/dia pode ser complementado por outros que demonstrem ser eficazes, de forma que se possa, em um dado 
momento, ratificar o indicador recomendado ou contrapor outros mais confiáveis para serem utilizados em edifícios públicos administrativos.

Por outro lado, existem variações no indicador de consumo para uma mesma tipologia de edifício, em função das diferenças de hábitos dos usuários, decorrentes de fatores culturais e climáticos, entre outros. Assim, essas diferenças devem ser consideradas quando do uso de um indicador de consumo levantado para uma dada edificação num determinado local. Assim, divisões geográficas que considerem variáveis climatológicas, como a temperatura, a pluviosidade e a umidade do ar, devem ser consideradas em estudos futuros.

Segundo Sant'Ana (2015), “os indicadores de consumo de água utilizam-se de unidades paramétricas temporais para a comparação de valores-base que ‘indicam’ o consumo de água de determinada edificação e podem ser utilizadas na previsão de demandas de água, avaliação de programas de conservação de água e no dimensionamento de sistemas prediais". Gonçalves (2009) acrescenta ainda que os indicadores auxiliam na avaliação de diversos fatores, tais como a eficiência, custos, perdas, investimentos e qualidade, entre outros.

Como o objetivo desta pesquisa não é a verificação do grau de representatividade dos indicadores propostos, também serão disponibilizados outros encontrados na literatura internacional, como já listado no capítulo anterior, a título exemplificativo. Nesse caso, os indicadores referentes ao conjunto arquitetônico do TCU são os listados na Tabela 22, na qual há alguns aspectos que devem ser considerados: a) no caso dos Anexos I e II, foi seguida uma proporcionalidade em relação à variável de cada coluna, em relação ao consumo, que, como já visto antes, é medido de forma conjunta, devido ao hidrômetro instalado, que atende a esses dois edifícios e ao Restaurante; e b) foi considerada área de escritórios qualquer ambiente de permanência prolongada, sendo, portanto, excluídos ambientes como circulações horizontais e verticais, depósitos, salas técnicas e shafts, entre outros.

Tabela 22 - Lista consolidada dos indicadores dos edifícios do TCU em Brasília/DF

\begin{tabular}{|c|c|c|c|c|c|}
\hline Edifício & $\begin{array}{c}\text { Consumo } \\
\text { per capita } \\
\text { (l/p/dia) }\end{array}$ & $\begin{array}{c}\text { Consumo } \\
\text { per capita } \\
(\mathbf{l} / \mathbf{p} / \mathbf{a n o})\end{array}$ & $\begin{array}{c}\text { Consumo por área } \\
\text { construída } \\
\left(\mathbf{l} / \mathbf{m}^{2} / \mathbf{a n o}\right)\end{array}$ & $\begin{array}{c}\text { Consumo por área } \\
\text { de cobertura } \\
\left(\mathbf{l} / \mathbf{m}^{2} / \mathbf{a n o}\right)\end{array}$ & $\begin{array}{c}\text { Consumo por área } \\
\text { escritórios } \\
\left(\mathbf{l} / \mathbf{m}^{2} / \mathbf{a n o}\right)\end{array}$ \\
\hline Ed. Sede & 41,41 & $14.907,21$ & 606,77 & $3.082,84$ & $1.135,80$ \\
\hline Anexo I & 20,87 & $7.513,79$ & 498,99 & $2.569,53$ & $1.024,43$ \\
\hline Anexo II & 20,08 & $7.228,29$ & 606,65 & $3.134,24$ & $1.337,25$ \\
\hline Anexo III & 34,80 & $12.528,87$ & 578,54 & $4.628,35$ & $1.224,86$ \\
\hline $\begin{array}{c}\text { Complexo } \\
\text { TCU }\end{array}$ & 42,42 & $15.269,80$ & 834,88 & $4.900,16$ & $1.664,70$ \\
\hline
\end{tabular}




\subsection{Caracterização de usos finais de água}

Neste item serão discriminados a metodologia e os resultados obtidos em relação aos usos finais de água no conjunto edificado do TCU, após a aplicação de questionários de informação de hábitos de consumo aos usuários.

Diante da falta de mecanismos precisos de controle e da impossibilidade de instalação de medidores em cada ponto de consumo ou conjunto de pontos, tendo em vista a extensa área estudada, entre outros motivos, optou-se pela aplicação de pesquisa estruturada para a coleta das informações. Para a verificação da fidelidade e representatividade das informações extraídas deste trabalho de campo, também se definiu pelo confronto com os valores de consumo informados pela concessionária local.

No teste piloto, foram aplicados 70 questionários em alguns ambientes de trabalho do Anexo III do TCU, onde há servidores, terceirizados e estagiários trabalhando, equivalente a cerca de $2 \%$ da população total.

Nesta fase foram identificadas algumas necessidades de reforço nos esclarecimentos acerca da pesquisa, especialmente a que local de utilização se referiam as perguntas. Também foram ajustados os intervalos de respostas e a clareza dos textos das perguntas.

Os dados coletados foram compilados e resultaram em informações muito próximas das medições mensais da concessionária local, como se pode concluir pela Tabela 23, com distribuição dos usos finais desenhados no Gráfico 10. Do mesmo modo, foi possível testar quais ponderações deveriam ser consideradas no tratamento dos dados, quando aplicados à população inteira do estudo de caso, como, por exemplo:

- Deveriam ser desconsideradas para efeito de pesquisa as respostas fora de intervalos máximos ou que fossem claramente equivocados, por falha na leitura de enunciados ou erro de estimativa;

- No cálculo do número de dias anuais de uso do edifício, deveriam ser desconsiderados os finais de semana e os dias de férias e recessos de cada tipo de usuário;

- Como há muitos feriados ao longo do ano, tais datas deveriam ser desconsideradas para efeito de cálculo de consumo anual;

- No cálculo de consumo de água do mictório, em que o uso é segmentado por gênero, a ponderação deveria ser parcial. 
Tabela 23 - Síntese dos resultados de teste piloto no Anexo III do TCU em Brasília/DF

\begin{tabular}{|c|c|c|}
\hline Uso final & Consumo (litros) & Representatividade \\
\hline Limpeza & 252.872 & $29,8 \%$ \\
\hline Irrigação & 348.659 & $41,1 \%$ \\
\hline Equipamentos & 245.759 & $29,0 \%$ \\
\hline
\end{tabular}

\begin{tabular}{|c|c|}
\hline Consumo estimado pelo teste piloto & 847.290 \\
\hline Consumo médio medido & 874.083 \\
\hline Diferença & $3,16 \%$ \\
\hline
\end{tabular}

Gráfico 10 - Representatividade dos usos finais do teste piloto do Anexo III do TCU em Brasília/DF

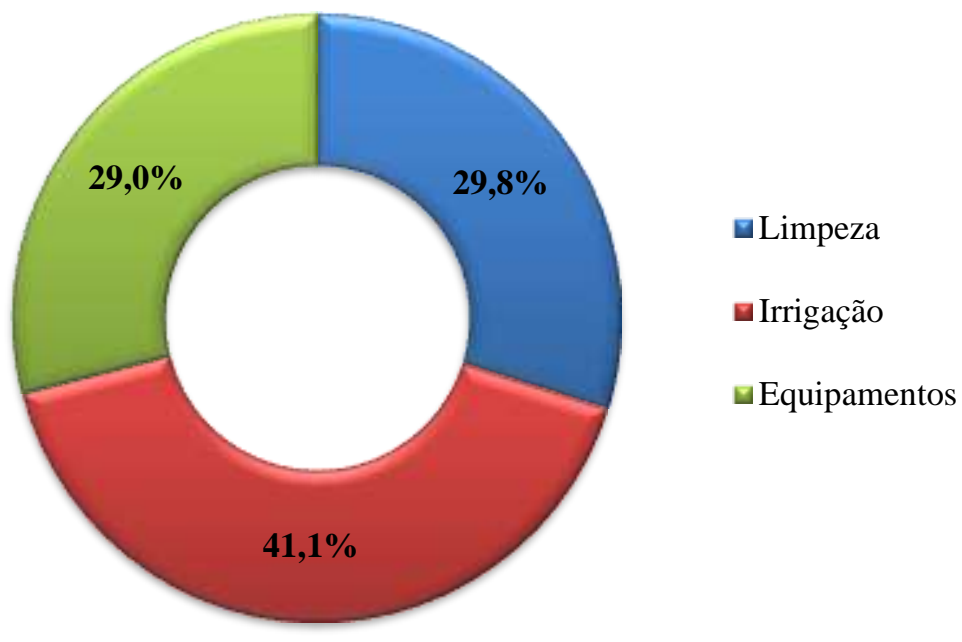

Quando desagregado o item referente a equipamentos, o teste piloto mostrou a representatividade dos usos finais de cada peça sanitária, conforme detalha o Gráfico 11. Vale ressaltar que no teste piloto não foram considerados os usos dos filtros e das duchas higiênicas. Tal omissão foi corrigida no levantamento definitivo.

Gráfico 11 - Representatividade dos usos finais do teste piloto dos equipamentos do Anexo III do TCU em Brasília/DF

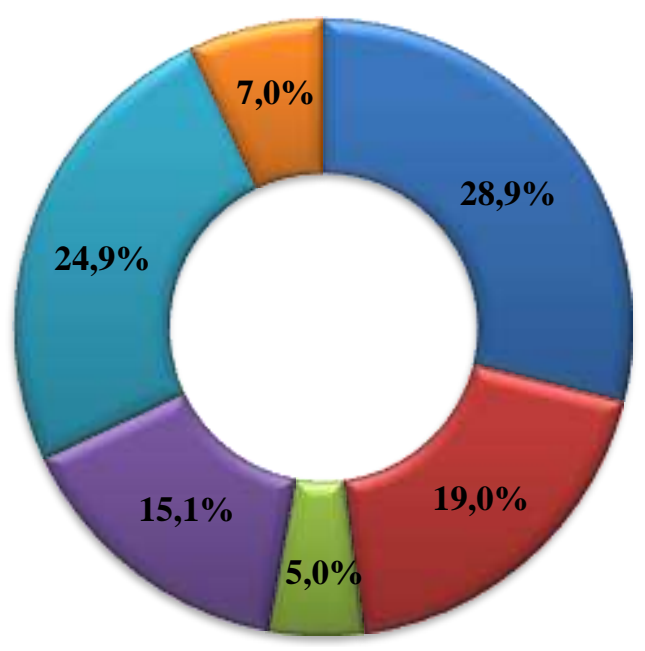

-Descarga parcial 3 litros

๑Descarga total 6 litros

四 Mictório

- Torneira do lavatório

Torneira da copa

田Chuveiro 


\subsubsection{Política de Sustentabilidade do TCU}

Na mesma época em que foram obtidos os resultados do teste piloto, descobriu-se que o TCU estava prestes a aprovar uma resolução interna que poderia respaldar uma pesquisa institucional mais ampla, tendo em vista um possível preconceito e desinteresse dos respondentes com uma pesquisa de caráter apenas acadêmico.

Após um período de espera, em 4 de março de 2015 foi aprovada no TCU, por meio do Acórdão no 329/2015 - Plenário, a Resolução no 268/2015, que instituía a Política Institucional de Sustentabilidade do TCU (PSUS/TCU), provocando também alterações na política de gestão de pessoas e no planejamento estratégico daquele órgão. Tal instrumento considerou a necessidade de promoção da economia de recursos naturais com concomitante redução de gastos institucionais, bem como de revisão dos padrões de produção e consumo com adoção de novos referenciais no âmbito da administração pública.

Nesta resolução foi criado o Comitê Gestor de Logística Sustentável do TCU (CLS/TCU) e legitimado o Programa de Logística Sustentável (PLS/TCU) daquele órgão, obrigatório para os órgãos públicos desde a edição do Decreto Federal n $n^{\circ} 7.746 / 2012$. Diante desse fato, foram realizadas reuniões com os representantes legais para verificar a possibilidade de aplicação do questionário do teste piloto em todo o TCU com o devido respaldo institucional.

Como o PSUS/TCU não tratava apenas de estratégias conservadoras de água, foi solicitado que fosse desenvolvida pesquisa um pouco mais ampla, no sentido que subsidiasse a elaboração do PLS/TCU, com a elaboração de um diagnóstico de situação socioambiental prévio, de acordo com os $\S \S 2^{\circ}$ e $3^{\circ}$ do art. 12 da mesma resolução.

Após a regulamentação do CLS/TCU, por meio da Portaria no 193/2015, de 2 de junho de 2015, da Presidência do TCU, foram realizadas reuniões do CLS/TCU, nas quais foi autorizada a aplicação do questionário no âmbito interno, especificamente em Brasília/DF, com previsão de posterior ampliação para os demais estados da Federação. Pelo fato de o questionário ter ficado extenso numa primeira versão, optou-se por submetê-lo separado por temas: uso da água e uso da energia, num primeiro momento e os outros temas posteriormente. Também foi definido que a abrangência seria restrita, de forma que houvesse oportunidade de incorporação de eventuais sugestões dos respondentes. A versão final do questionário encontra-se no Anexo 1. O questionário foi enviado/distribuído a 1.683 pessoas. 


\subsubsection{Aplicação de pesquisa estruturada}

O questionário foi divulgado no período de 12/08/2015 a 16/08/2015, com o envio de mensagens aos dirigentes dos setores participantes, explicando pormenorizadamente os objetivos da pesquisa e solicitando suas colaborações no sentido de estimular os integrantes de suas equipes a responderem ao questionário da melhor maneira possível. A pesquisa foi disponibilizada para preenchimento de 17/08/2015 a 31/08/2015, com a efetiva participação de 527 usuários. Os dados básicos compilados, com distribuição por tipo de usuário, sexo e local de trabalho estão informados na Tabela 24.

Tabela 24 - Dados de distribuição das respostas da pesquisa de usos finais de água no TCU em Brasília/DF

\begin{tabular}{|c|c|c|c|}
\hline \multirow{2}{*}{ Dado } & Tipologia & $\begin{array}{c}\text { Quantidade de } \\
\text { respostas }\end{array}$ & Representatividade \\
\hline \multirow{3}{*}{ Tipo de usuário } & Servidores & 168 & $32,00 \%$ \\
\cline { 2 - 4 } & Terceirizados & 169 & $30,29 \%$ \\
\cline { 2 - 4 } & Estagiários & 190 & $31,67 \%$ \\
\hline \hline \multirow{3}{*}{ Sexo } & Masculino & 252 & $47,8 \%$ \\
\cline { 2 - 4 } & Feminino & 275 & $52,2 \%$ \\
\hline \hline \multirow{3}{*}{ Local de trabalho } & Edifício Sede & 100 & $18,98 \%$ \\
\cline { 2 - 4 } & Anexo I & 208 & $39,47 \%$ \\
\cline { 2 - 4 } & Anexo II & 116 & $22,01 \%$ \\
\cline { 2 - 4 } & Anexo III & 103 & $19,54 \%$ \\
\hline
\end{tabular}

A maior preocupação da restrição de envio a uma parte dos usuários do TCU foi que a representatividade fosse muito pequena. Como o quantitativo de respostas representou mais de $30 \%$ em todos os segmentos envolvidos, considerando a população que efetivamente teve acesso ao questionário, a amostra foi considerada representativa, com números próximos aos estudos de Marinoski e Ghisi (2008) e Kammers e Ghisi (2006). Há que se destacar a grande representatividade do Anexo I nesta pesquisa, especialmente devido à concentração das atividades-meio do TCU nesse edifício. Como o extrato da pesquisa abrangeu usuários das áreas administrativas, houve essa participação expressiva. Também merece registro o equilíbrio de respostas de ambos os sexos, demonstrando unidade nas respostas.

Um aspecto que merece um comentário em separado é a parte da pesquisa que foi feita com o auxílio de questionários em papel. Terceirizados das áreas de limpeza, vigilância, brigada de incêndio, copeiragem, manutenção predial e portaria foram instados a responder o questionário, ressalvadas as perguntas de consumo de energia, que não se aplicavam a eles, pois são profissionais que não tem acesso à rede interna de computadores do TCU. 
A participação foi expressiva e totalmente fora do esperado, com a entrega de 265 questionários. Como já havia 87 respostas registradas na pesquisa on-line, a totalização de respostas de terceirizados ficaria cerca de duas vezes maior que a dos outros tipos de usuários. Diante desse fato, foi definido que o peso dessas respostas em papel seria totalizado até que a representatividade desse item ficasse em 30\%, próxima às outras. Tal ação se mostrou necessária porque os usos finais desse grupo de profissionais são distintos dos outros, não sendo comparável um consumo de água de profissionais que atuam nas copas ou na limpeza, por exemplo, com o consumo dos que exercem atividades administrativas.

\subsubsection{Resultados da pesquisa estruturada}

O principal resultado da pesquisa de campo no que concerne ao uso de equipamentos pelos usuários, dentro do conjunto edificado do TCU em Brasília, está consolidado na Tabela 25. As respostas enquadradas na opção "Outros", disponibilizadas na pesquisa, devido ao seu número exíguo de aparições, foram transformadas em múltiplos das respectivas opções, tomando-se o devido cuidado para não modificar o número total de respondentes.

Tabela 25 - Resultados finais consolidados da pesquisa de usos finais de água nas dependências do TCU em Brasília/DF

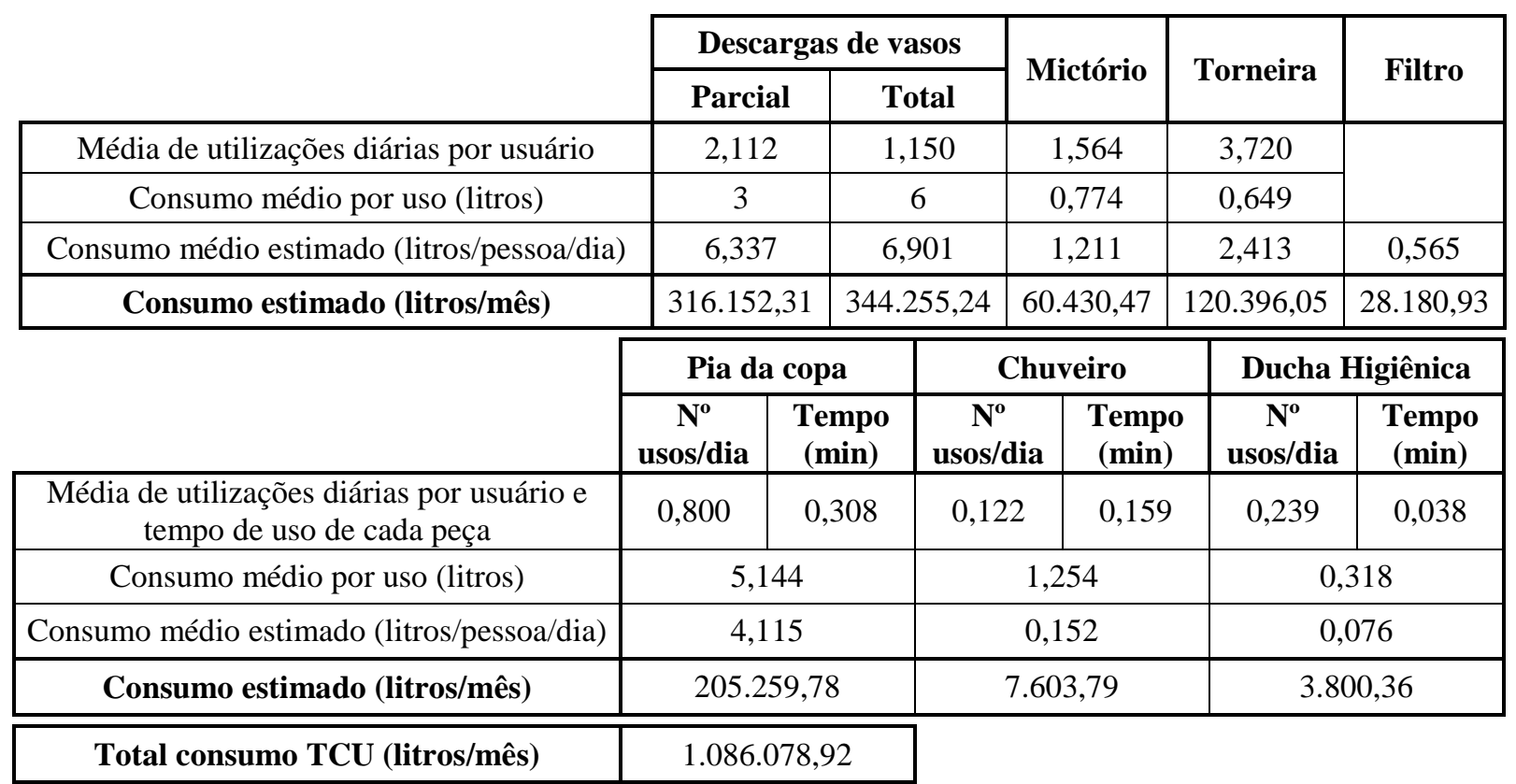

Após esse cálculo, chegou-se ao consumo total estimado de equipamentos no TCU, somandose todos os consumos itemizados na Tabela 25, cuja representatividade está consolidada no Gráfico 12. 
De posse desse dado, juntamente com os dados de consumo estimados de irrigação e limpeza, bem como dados específicos de consumo nos espelhos d'água e lavagem de veículos nas áreas internas e externas, chega-se aos usos finais de água do conjunto edificado do TCU em Brasília, por tipo de uso e por unidade edilícia, conforme apontam os Gráficos 13 e 14.

Gráfico 12 - Representatividade dos usos finais de água dos equipamentos instalados nos edifícios do TCU em Brasília/DF

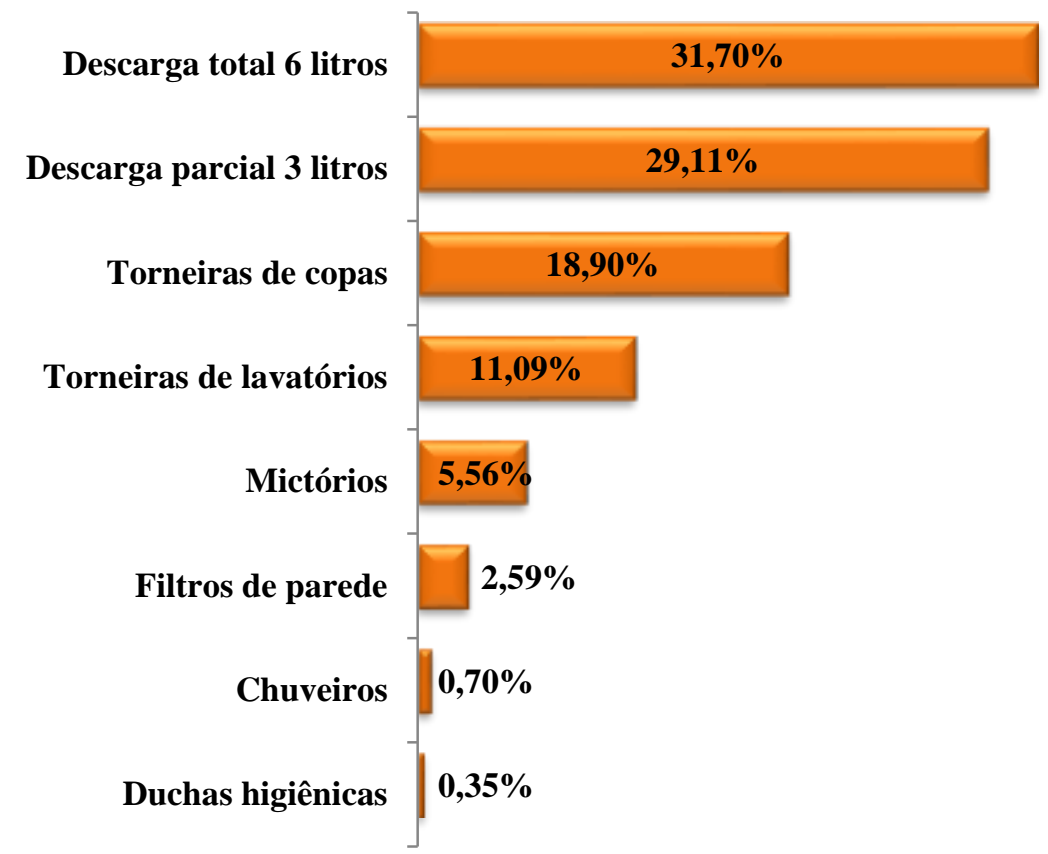

Note-se que no Gráfico 13 há um tipo de uso intitulado "Outros usos", em que se enquadram usos diversos dos anteriormente listados, como vazamentos, limpeza de reservatórios, manutenção da rede sanitária, uso inapropriado de peças sanitárias, entre outros.

Gráfico 13 - Usos finais de água nos edifícios do TCU em Brasília/DF

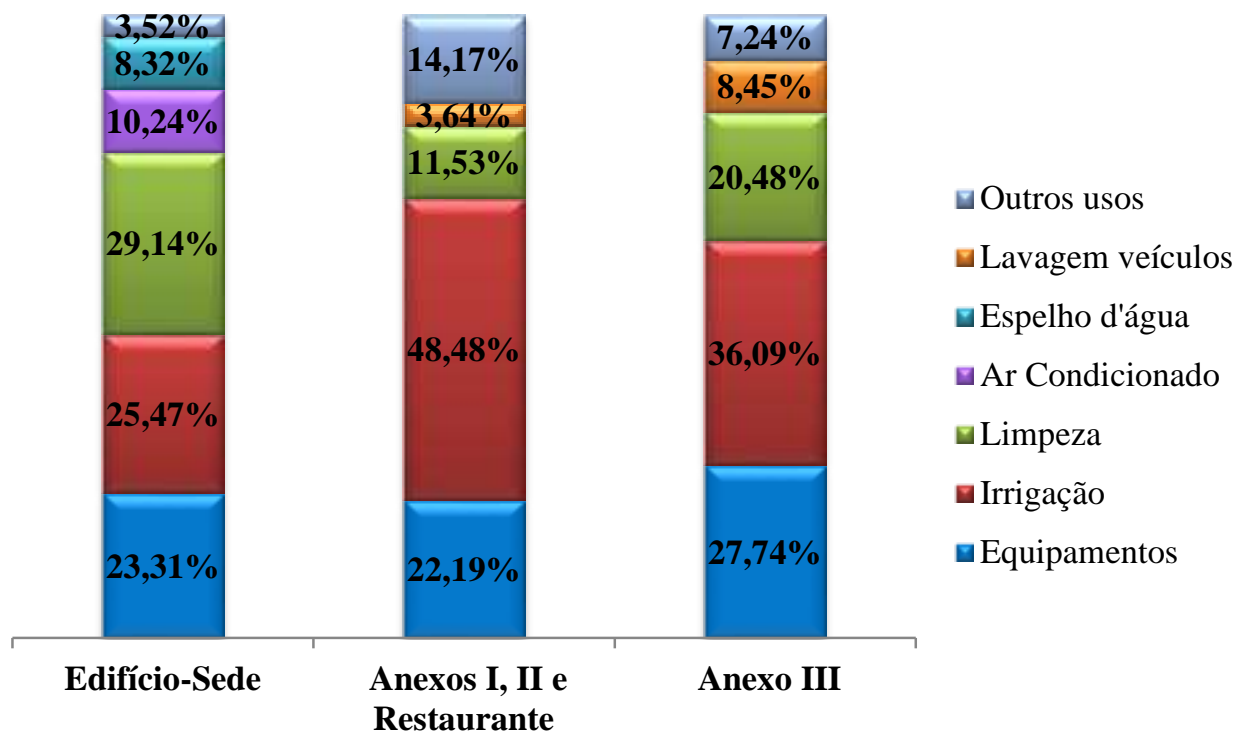


Os impactos dos usos de cada edifício, a depender do volume de água consumido, foram incorporados ao Gráfico 14, que demonstra os usos finais de água em todo o conjunto edificado de Brasília/DF.

Gráfico 14 - Usos finais de água de todo o conjunto edificado do TCU em Brasília/DF

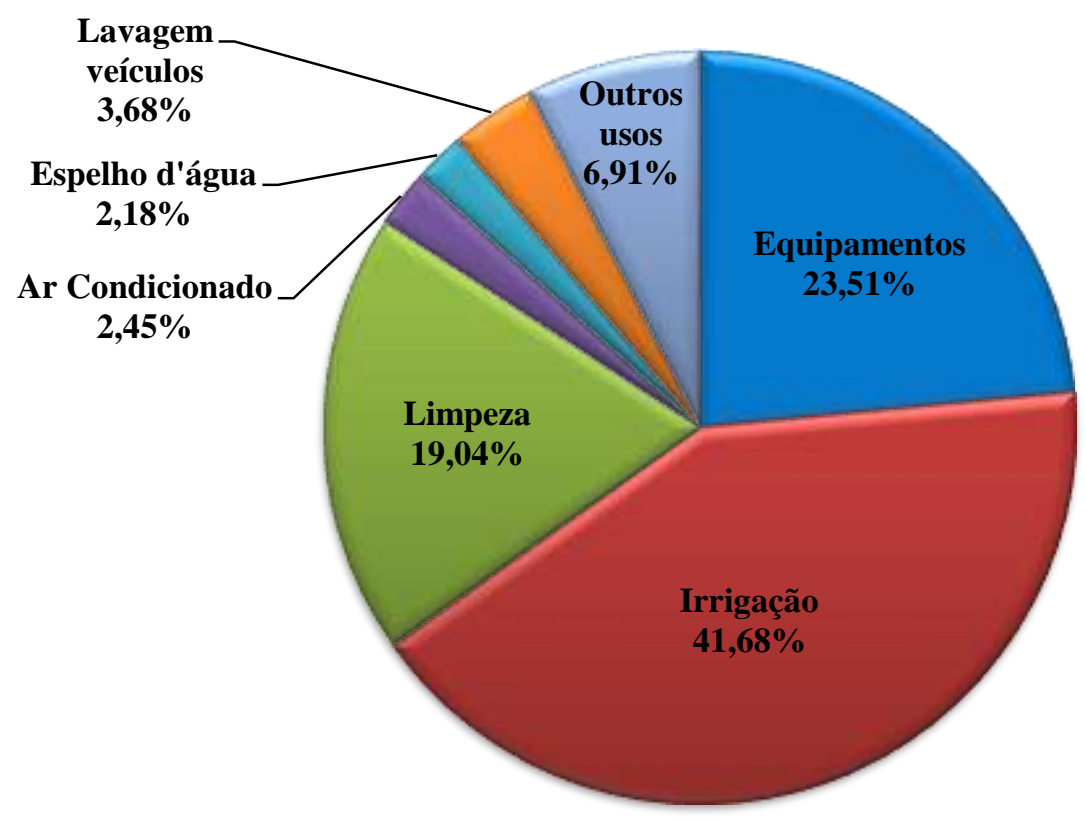

Há que se destacar, na leitura do Gráfico 13, a grande participação da irrigação nos usos finais dos Anexos I, II e Restaurante, dado que os sistemas fixos de aspersão são creditados ao consumo final deste edifício. Dentro do mesmo assunto, também é de se notar a diferença de representatividade de consumo nos Edifício-Sede e Anexos I, II e Restaurante em relação aos estimados na Tabela 17 (p. 163). Isso se justifica pela relativa imprecisão nos levantamentos de vazões dos sistemas de irrigação do TCU. Os dados descritos no Gráfico 13 foram levantados pela diferença de leituras dos hidrômetros interno e externo que o TCU possui em seus jardins, com exceção do Anexo III. Neste último caso, a representatividade foi estimada na mesma Tabela 17.

É ainda importante frisar que os consumos de lavagem de veículos e o de irrigação tendem a sofrer reduções, visto que em breve o sistema de lavagem de veículos será ecológico (com consumo máximo de 2 litros por lavagem) e o sistema de irrigação será todo automático, com utilização em período noturno e caracterizado pela grande eficiência.

\subsection{Diagnóstico do consumo}

Após a conclusão dos levantamentos de todas as características dos sistemas que utilizam água e da aplicação das entrevistas estruturadas, foi possível definir os perfis existentes de 
consumo em cada edifício e no conjunto total edificado do TCU, que servirão como subsídio para um futuro plano de intervenção.

Neste item foram identificados com clareza os consumos de equipamentos, irrigação e limpeza de cada um dos edifícios componentes do conjunto edificado do TCU. Cada vertente tem sua importância no consumo e nos elementos específicos que a compõem. Nos Gráficos 13 e 14, foram resumidas as informações coletadas na auditoria de consumo de água de cada edifício pesquisado e de todo o conjunto edificado do TCU em Brasília.

Apesar de as recomendações de ANA et al. (2005) sugerirem prover o diagnóstico de consumo de informações acerca de perdas de água provenientes de vazamentos, inclusive dos sistemas hidráulicos especiais, bem como desperdício diário estimado, não foi possível, nesta pesquisa, identificar tais consumos.

\subsubsection{Equipamentos}

A análise dos equipamentos sanitários no TCU mostrou uma preocupação dos especificadores técnicos em dispor de tecnologia que economize água sem interferir no cotidiano dos usuários. Os valores absolutos de consumo mostram uma tendência de queda ano a ano. A troca de tubulações em recente reforma do Edifício-Sede mostrou que, pelos 40 anos passados de sua inauguração, era provável que existissem muitos pontos de vazamentos antes dessa intervenção. Após alguns meses de finalizada a reforma, é clara a redução no consumo.

Os equipamentos instalados não precisam de troca pelo estado de conservação em que se encontram, mas é importante a atualização de tecnologias que permitam a redução do consumo sem perder a qualidade no seu uso, como, por exemplo, o uso de restritores de vazão em torneiras e chuveiros ou o uso de mictórios que dispensem a água para limpeza.

As torneiras usadas no restaurante deveriam ser trocadas por modelos que possuam maior área de esguicho, com necessária manutenção da pressão. No modelo existente, foram retirados os pulverizadores, por provocar redução da pressão e perda da qualidade e eficiência dos serviços.

Os mictórios, se mantidos os modelos atuais, precisam de maior atenção na manutenção, pois, durante o levantamento de vazões, foram constatados problemas em várias peças e variações consideráveis de vazão. Essa regularidade de manutenção preventiva gera a redução da incidência de manutenções corretivas, que, em muitos casos, são provocadas por manipulação indevida de registros, resultando em grande desperdício de água. Não há qualquer sugestão 
acerca do uso e dos modelos utilizados no TCU de vasos sanitários, chuveiros, duchas higiênicas e filtros de parede.

As vazões dos elementos sanitários foram condizentes com as informadas em outras pesquisas [Kammers \& Ghisi (2006); Proença \& Ghisi (2009); Marinoski \& Ghisi (2008)] e com informações de fabricantes, descritas na Tabela 26. Por outro lado, o tempo médio de abertura das peças teve uma variação elevada, o que demonstra uma falta de critério da manutenção na regulagem das peças. $\mathrm{Na}$ vistoria diária que é feita pela manutenção, não foi percebida qualquer preocupação com essa regularidade de vazões das diversas peças sanitárias e entre os edifícios do mesmo conjunto edificado.

Tabela 26 - Vazões de peças sanitárias utilizadas no TCU em Brasília/DF comparadas com as informações dos fabricantes

\begin{tabular}{|c|c|c|c|c|c|}
\hline Equipamento & $\begin{array}{c}\text { Vazões/tempos } \\
\text { informados } \\
\text { pelo fabricante }\end{array}$ & $\begin{array}{c}\text { Vazões/tempos } \\
\text { considerados } \\
\text { ou aferidos } \\
\text { no TCU }\end{array}$ & $\begin{array}{c}\text { Vazão sugerida } \\
\text { para redução de } \\
\text { demanda }\end{array}$ & $\begin{array}{c}\text { Redução de } \\
\text { consumo } \\
\text { estimada no } \\
\text { item }\end{array}$ & $\begin{array}{c}\text { Redução de } \\
\text { consumo } \\
\text { estimada } \\
\text { geral }\end{array}$ \\
\hline Mictórios & $81 / \mathrm{min}$ & $81 / \mathrm{min}$ & Zero & $100 \%$ & $1,31 \%$ \\
\hline Torneiras das copas & $81 / \mathrm{min}$ & $16,6981 / \mathrm{min}$ & $61 / \mathrm{min}$ & $64,07 \%$ & $2,85 \%$ \\
\hline $\begin{array}{c}\text { Arejadores das } \\
\text { torneiras dos lavatórios }\end{array}$ & $61 / \mathrm{min}$ & $6,1251 / \mathrm{min}$ & $1,81 / \mathrm{min}$ & $70,61 \%$ & $1,84 \%$ \\
\hline Chuveiros & 5 a $131 / \mathrm{min}$ & $7,8951 / \mathrm{min}$ & $61 / \mathrm{min}$ & $24,00 \%$ & $0,04 \%$ \\
\hline \hline $\begin{array}{c}\text { Tempo de abertura das } \\
\text { torneiras dos lavatórios }\end{array}$ & $4 \mathrm{a} 10 \mathrm{seg}$ & $6,180 \mathrm{seg}$ & $5 \mathrm{seg}$ & $19,09 \%$ & $0,50 \%$ \\
\hline
\end{tabular}

Fonte: Deca

Quanto aos procedimentos inadequados dos usuários relacionados ao consumo de água, há que se orientar, por meio de campanhas de divulgação, acerca dos procedimentos relativos aos usos dos equipamentos, com programação visual clara e objetiva, informando, entre outros assuntos, sobre:

- Identificação de uso do mecanismo de duplo comando dos vasos sanitários, com aposição de adesivo na parede, com desenho identificando os botões destinados à descarga de efluentes líquidos e sólidos;

- Alerta sobre a possibilidade de entupimento dos vasos sanitários em caso de utilização para descartar papéis diversos, absorventes íntimos e outros objetos de descarte comum;

- Identificação de uso das torneiras com sistema hidromecânico, com aposição de adesivo nos espelhos mostrando a maneira correta de manipulação;

- Orientação dos colaboradores da limpeza quanto à correta higienização das peças 
sanitárias, em especial das duchas higiênicas e vasos sanitários, informando-os que aqueles ambientes, se indevidamente limpos, são potenciais vetores de várias doenças;

- Orientação aos profissionais da manutenção sobre os procedimentos corretos de manutenção, caso a caso, com eventual suporte de representantes dos fabricantes.

\subsubsection{Irrigação e limpeza}

Percebe-se que o TCU tem tomado algumas ações pontuais para a redução do consumo, especialmente em irrigação. Os jardins do TCU, assinados pelo paisagista Burle Marx, externamente necessitam de cuidados de rega diários, pela presença de várias espécies exóticas. Como não há um controle nessas regas e elas são feitas pela manhã, as perdas por evaporação são grandes, demonstrando a ineficácia na condução da gestão da jardinagem.

A irrigação, depois de implantado seu novo projeto, que abrangerá toda a área ajardinada do TCU em Brasília, demandará uma solução que também reduza o consumo de água da concessionária, posto que não há necessidade de uso de água potável nesse consumo. Nesse caso, soluções de instalações de sistemas de aproveitamento de águas pluviais (AAPs) e uso de água proveniente de tratamentos de águas cinzas (TACs) ou residuárias (TARs) são recomendadas, notadamente pelo grande volume de água consumido.

No que tange à limpeza, há consumos que podem ser reduzidos. Um deles é o de limpeza das garagens e de áreas externas, como a entrada dos edifícios, corredores externos do EdifícioSede e passarela de interligação. Nesses casos, tendo em vista a periodicidade e a extensão das áreas, é recomendável a compra de equipamentos de limpeza industrial de pisos, que garantem um resultado eficiente, com redução de mão de obra, que pode se transformar, em curto prazo, em redução de valor de gerenciamento da área de limpeza e redução das contas de água.

No caso da limpeza de fachadas, o uso de esguichos de mangueira mais econômicos ou lavadoras de alta pressão, desde que corretamente manipulados, podem contribuir na redução do consumo. O sistema de execução, por meio de cadeiras atirantadas na cobertura, pode ser substituído por pranchões com regulagem de altura por meio de cremalheiras ou por plataformas elevatórias articuladas do tipo tesoura. Tais soluções permitem uma maior precisão na limpeza e no enxágue dos vidros. 


\subsubsection{Sistema hidráulico e manutenção}

O sistema hidráulico do TCU é mantido por equipe de manutenção preventiva e não necessita de maiores ajustes. Se definida a implantação de sistemas AAP, TAC ou TAR, há que se fazer as devidas adaptações nos Anexos I, II e Restaurante para a separação de esgotos primários e secundários, a depender do sistema escolhido, bem como o treinamento das equipes.

Pelos relatos do gerente de manutenção predial do TCU, falta diálogo entre as áreas de projetos de arquitetura e engenharia e os fiscais de manutenção predial. Nesse caso, sempre há que se considerar quais são as melhores soluções, que atendam às duas áreas. Apenas para ilustrar, a torneira especificada na última reforma do Edifício-Sede é do mesmo fabricante das demais, diferenciando-se apenas no tamanho. Essa diferença gera uma grande dificuldade no ajuste de pressão das peças pela equipe de manutenção, pois o mecanismo de troca e o espaço para manuseio são reduzidos.

Também pareceu clara a necessidade de treinamento dos prestadores de serviço em relação à leitura de projetos de instalações, às soluções inovadoras de mercado, bem como acerca das normas e procedimentos exigidos pelo Corpo de Bombeiros Militar do Distrito Federal (CBMDF) quanto à ocorrência de sinistros.

\subsubsection{Indicadores}

No que tange aos indicadores, há que se salientar a pouca informação que existe na literatura brasileira. Tendo em vista as informações das Tabelas 6 e 22 (pp. 123 e 172), é possível concluir que os edifícios Anexos I e II estão dentro dos padrões médios de consumo. O Anexo III, com uma melhor ocupação de sua área, tende a reduzir esse indicador. No que diz respeito ao Edifício-Sede, por abrigar áreas de gabinetes de autoridades, espaço cultural, museu e auditório de 250 lugares, tende a ter uma ocupação mais rarefeita e aumentar os indicadores. Os dados relativos a indicadores do TCU foram consolidados na Tabela 27.

Se tomarmos como referência o programa NABERS da Austrália, no qual há classificações para o desempenho dos edifícios, todos os edifícios do conjunto edificado do TCU teriam uma ou duas estrelas, dentre as cinco possíveis, conforme as Tabelas 3 e 8 (pp. 119 e 143), na coluna de indicadores por área de escritórios. Também seguindo as mesmas tabelas, se consideradas as áreas construídas totais, os números se aproximariam ou se igualariam ao consumo de outros países europeus. 
Tabela 27 - Resumo dos indicadores de consumo de água dos equipamentos e sistemas do TCU em Brasília/DF

\begin{tabular}{|c|c|c|}
\hline Equipamentos & Indicador & Unidade de medida \\
\hline Vaso sanitário - descarga de 3 litros & 6,337 & \multirow{8}{*}{ litro/pessoa/dia } \\
\hline Vaso sanitário - descarga de 6 litros & 6,901 & \\
\hline Torneira de lavatórios & 2,413 & \\
\hline Torneira de copas & 4,115 & \\
\hline Mictórios & 1,211 & \\
\hline Chuveiros & 0,152 & \\
\hline Duchas higiênicas & 0,076 & \\
\hline Filtros de parede & 0,565 & \\
\hline Sistemas & Indicador & Unidade de medida \\
\hline Irrigação & 1,276 & litro/m² área jardins/dia \\
\hline Limpeza & 1,069 & litro/m² área útil/dia ${ }^{19}$ \\
\hline Ar Condicionado & 0,461 & litro/m² área condicionada/dia \\
\hline Espelho d'água & 1,393 & litro/m³ área espelhos d'água/dia \\
\hline Restaurante & 47,62 & litros/refeição/dia \\
\hline
\end{tabular}

ANA et al. (2005) indicam que ações de base operacional permitem manter sob controle os indicadores obtidos, assim como atualizada a avaliação da edificação quanto ao uso da água. Fazem parte dessas ações, entre outras:

- Geração de procedimentos específicos de uso da água nos processos prediais constantemente atualizados;

- Acompanhamento do monitoramento contínuo do consumo por meio de planilhas eletrônicas e gráficas;

- Vistorias aleatórias nos locais de maior consumo para avaliação do uso da água;

- Constante divulgação das novas metas e resultados obtidos para todos os usuários da edificação em estudo.

\subsection{Plano de intervenção}

Segundo ANA et al. (2005), o plano de intervenção deverá focar em ações que resultem em redução de perdas e vazamentos, realização de campanhas de sensibilização e educativas e instalação de tecnologias economizadoras nos pontos de consumo.

Pelo perfil de consumo dos edifícios que compõem o conjunto arquitetônico do TCU, é possível identificar que todos os edifícios precisam de uma maior atenção gerencial e de campanhas de sensibilização para promover a mudança de postura nos usuários, de forma a obter a melhor eficiência possível neste consumo.

\footnotetext{
${ }^{19}$ Desconsideradas as áreas dos subsolos e os consumos de água na lavagem de veículos e dos pisos dos subsolos.
} 
Neste item serão recomendadas ações que podem contribuir para aperfeiçoar a gestão hídrica do conjunto edificado do TCU, considerando as ponderações do diagnóstico de consumo e a partir do levantamento de tecnologias conservadoras de água existentes e aplicáveis ao caso concreto.

Ressalte-se que não fez parte do escopo desta pesquisa o estudo de período de retorno dos investimentos para inserção de tecnologias conservadoras de água na matriz hidráulica dos edifícios estudados. As sugestões, listadas a seguir, baseiam-se na indicação da literatura existente e vantagens de cada sistema estudado.

Recomenda-se, portanto, a execução das seguintes ações no conjunto edificado do Tribunal de Contas da União em Brasília/DF:

- Estudar a viabilidade de implantação de sistemas AAP, TAC ou TAR para a redução da oferta de água, com seu uso prioritário nos espelhos d’água, lavagem de veículos, alimentação de vasos sanitários e irrigação de jardins, pois são usos não potáveis e representam parcela importante no consumo final de água;

- Realizar a hidrometração de áreas molhadas do conjunto edificado do TCU, por prumada ou por pavimento e prumada, considerando o avanço atual do Programa de Logística Sustentável do TCU, que tem como uma das metas previstas a separação de hidrômetros de cada edifício;

- Comprar equipamentos e acessórios economizadores mais eficientes, como, por exemplo, mictórios sem uso de água, restritores de vazão em chuveiros (6 litros/min) e arejadores mais econômicos em lavatórios (1,8 litro/min);

- Verificar a possibilidade e aceitação de uso de esguichos maiores nas pias da cozinha do restaurante e nas copas, com solução antivandalismo e incorporando restritores de vazão;

- Definir cotas mais baixas das lâminas d'água dos espelhos d'água, de forma a reduzir o consumo nas reposições de água por evaporação e nas necessidades de reparos da impermeabilização;

- Implantar sistema automatizado de irrigação dos jardins externos e estudar a viabilidade de implantação da mesma solução nos jardins internos;

- Extinguir o uso de garrafas plásticas, mesmo gerando aumento de consumo nos filtros, pois acarreta uma redução de custos financeiros e proporciona uma redução expressiva na produção de resíduos de plástico, contribuindo para a conservação do meio ambiente;

- Promover a conscientização do público interno para a importância da redução do consumo 
de água nas dependências do TCU, com distribuição de folders e revistas, envio de informações on-line na rede interna de computadores, campanhas com a participação de especialistas e familiares dos usuários, entre outras ações;

- Definir metas de redução de consumo com base nos dados coletados nesta pesquisa, que servirão como base para programas. Um bom exemplo é o plano implantado nos órgãos públicos dos EUA, onde a Ordem Executiva 13514 (2009) estabeleceu uma meta de redução de $2 \%$ ao ano a partir de um ano base.

Segundo ANA et al. (2005), deve-se desenvolver um estudo detalhado para que os investimentos sejam efetivamente aproveitados e o empreendimento tenha o retorno esperado. Tomando por base os levantamentos de custos de implantação das TCAs, devem ser dimensionados os equipamentos, os volumes de reservas necessários, os possíveis volumes complementares de água, bem como escolhidas as tecnologias de tratamento a serem empregadas. Com base nas alternativas de sistemas geradas, determinam-se quais as de maior eficiência, tanto no aspecto técnico quanto no econômico.

Esta etapa consiste, basicamente, na elaboração da matriz de soluções e na análise técnica e econômica para avaliação da viabilidade de ações e medidas a serem incorporadas no planejamento do programa de conservação da água. A implantação do programa deve, inicialmente, avaliar os custos correspondentes, tanto em relação ao investimento inicial quanto os relativos à operação e manutenção, avaliando, em paralelo, os benefícios associados. (MINISTÉRIO DO MEIO AMBIENTE, 2014)

Como esta pesquisa não se aprofunda na análise econômica das ações, para o caso em tela, a partir das sugestões de ações supracitadas, foi elaborado, como contribuição, o Quadro 29, que propõe metas para as quais são estimadas reduções no consumo total ou parcial dos edifícios que compõem o conjunto edificado do TCU.

Cabe esclarecer que os cálculos de redução da vazão de consumo das torneiras da cozinha do restaurante se basearam numa vazão aferida de 26,2 litros/minuto, que se reduziria para 8 litros/minuto.

No caso do percentual de aumento do consumo de água no TCU em virtude da extinção das garrafas de plástico, foi considerado que a quantidade média de água consumida nos filtros de parede passaria para 2 litros/pessoa/dia, volume mínimo diário de consumo de água recomendado pelos médicos para adultos. 
Quadro 29 - Metas, expectativas e reduções de consumo de água em virtude de ações sugeridas no plano de intervenção

\begin{tabular}{|c|c|c|}
\hline Ação & Meta/Expectativa & $\begin{array}{c}\text { Redução definida/esperada no } \\
\text { consumo de água do TCU }\end{array}$ \\
\hline $\begin{array}{c}\text { Implantar sistemas AAP, TAC ou } \\
\text { TAR. }\end{array}$ & $\begin{array}{c}\text { Redução de oferta de água para } \\
\text { consumo. }\end{array}$ & $\begin{array}{l}\text { Intervalo variável de redução, a } \\
\text { depender especialmente do volume } \\
\text { do reservatório construído, do } \\
\text { subsistema proposto e dos locais que } \\
\text { serão abastecidos pela água tratada. }\end{array}$ \\
\hline $\begin{array}{l}\text { Implantar sistema automatizado de } \\
\text { irrigação dos jardins externos. }\end{array}$ & $\begin{array}{c}\text { Manutenção ou redução da atual } \\
\text { demanda de água para a área } \\
\text { ajardinada do TCU. }\end{array}$ & $\begin{array}{l}\text { Possível redução de consumo, em } \\
\text { razão de informações de pressão de } \\
\text { água da concessionária, da tipologia } \\
\text { das plantas e do solo e da eficiência } \\
\text { dos equipamentos instalados. }\end{array}$ \\
\hline $\begin{array}{l}\text { Executar hidrometração de áreas } \\
\text { molhadas. }\end{array}$ & $\begin{array}{c}\text { Controle de vazamentos e de } \\
\text { demanda dos pavimentos dos } \\
\text { edifícios. }\end{array}$ & $\begin{array}{l}\text { Possível redução de consumo pela } \\
\text { detecção de vazamentos ou pela } \\
\text { conscientização dos usuários acerca } \\
\text { do controle exercido. }\end{array}$ \\
\hline $\begin{array}{l}\text { Comprar equipamentos e } \\
\text { acessórios economizadores mais } \\
\text { eficientes. }\end{array}$ & $\begin{array}{l}\text { Redução da demanda de água por } \\
\text { meio de tecnologias sem } \\
\text { participação do usuário. }\end{array}$ & $\begin{array}{c}\text { 6,53\% de redução no consumo de } \\
\text { água no TCU, dadas as vazões } \\
\text { aferidas nos equipamentos do TCU e } \\
\text { as vazões dos acessórios informados } \\
\text { pelo fabricante, conforme detalhado } \\
\text { na Tabela } 28 .\end{array}$ \\
\hline $\begin{array}{c}\text { Comprar esguichos maiores nas } \\
\text { pias da cozinha do restaurante e } \\
\text { nas copas, com solução } \\
\text { antivandalismo e incorporando } \\
\text { restritores de vazão. }\end{array}$ & $\begin{array}{c}\text { Redução da demanda de água por } \\
\text { uso de redutores de pressão }+ \\
\text { conforto na utilização nas tarefas } \\
\text { do restaurante com o uso de } \\
\text { esguichos de maior diâmetro. }\end{array}$ & $\begin{array}{c}30,56 \% \text { de redução da vazão das } \\
\text { torneiras da cozinha do restaurante, } \\
\text { com possibilidade de redução do } \\
\text { consumo. }\end{array}$ \\
\hline $\begin{array}{c}\text { Definir cotas mais baixas das } \\
\text { lâminas d'água dos espelhos } \\
\text { d'água. }\end{array}$ & $\begin{array}{l}\text { Redução da demanda pela } \\
\text { redução do volume } \\
\text { eventualmente esgotado para } \\
\text { limpeza ou impermeabilização do } \\
\text { espelho d'água. }\end{array}$ & $\begin{array}{l}\text { 1,09\% de redução no consumo de } \\
\text { água no TCU, tendo em vista os } \\
\text { cálculos já definidos no Gráfico } 13 \text {. }\end{array}$ \\
\hline $\begin{array}{l}\text { Extinguir o uso de garrafas } \\
\text { plásticas. }\end{array}$ & $\begin{array}{l}\text { Redução do impacto do aumento } \\
\text { do uso de água dos filtros de } \\
\text { parede, estimando o impacto } \\
\text { financeiro e ambiental desta ação. }\end{array}$ & $\begin{array}{c}1,55 \% \text { de aumento do consumo de } \\
\text { água no TCU, R\$ } 990 \text { mil de redução } \\
\text { do impacto financeiro e redução do } \\
\text { impacto de } 1,5 \text { milhão garrafas } \\
\text { plásticas de } 500 \text { ml ao ano no meio } \\
\text { ambiente. }\end{array}$ \\
\hline $\begin{array}{l}\text { Definir metas de redução de } \\
\text { consumo de água em todo o TCU. }\end{array}$ & $\begin{array}{l}\text { Redução da demanda de água por } \\
\text { meio de metas tangíveis, até se } \\
\text { estabelecerem níveis excelentes } \\
\text { de consumo, considerando } \\
\text { indicadores de fácil controle. }\end{array}$ & $\begin{array}{l}\text { Sugestão de redução anual de } 2 \% \text { no } \\
\text { consumo de água no TCU, com meta } \\
\text { de atingimento de indicador } \\
\text { considerado excelente pela literatura } \\
\text { nacional ou internacional. }\end{array}$ \\
\hline
\end{tabular}

A auditoria do consumo mostrou padrões por vezes próximos e outros distintos aos desenvolvidos em outras pesquisas que tratam do mesmo tema, como Kammers \& Ghisi (2006) e Sant'Ana (2013), cujo foco são edifícios públicos, e Proença \& Ghisi (2009), que trata dos usos finais em edifícios comerciais, conforme comparativo apresentado na Tabela 28. Não foram verificadas, de forma geral, distorções relevantes entre os números apresentados, exceto no uso de alguns aparelhos sanitários, como os mictórios e torneiras de lavatórios, bem como no uso dos restaurantes. Tais indicadores podem possuir distorções não 
detectadas nas respectivas pesquisas, bem como terem sido feitas em edifícios com morfologias e distribuição de áreas muito distintas.

Tabela 28 - Comparativo de resultados da auditoria de usos finais de água do TCU em Brasília/DF com outras pesquisas

\begin{tabular}{|c|c|c|c|c|}
\hline Indicador de consumo & $\begin{array}{l}\text { Proença } \\
\text { \& Ghisi } \\
(2009)\end{array}$ & $\begin{array}{c}\text { Kammers } \\
\text { \& Ghisi } \\
(\mathbf{2 0 0 6 )} \\
\end{array}$ & $\begin{array}{l}\text { Sant'Ana } \\
\quad(2013)\end{array}$ & Dados TCU \\
\hline $\begin{array}{l}\text { Consumo médio de água por pessoa } \\
\text { (litros/pessoa/dia) no conjunto de edifícios }\end{array}$ & 36,71 & 57,78 & 48,00 & $\begin{array}{l}37,17 \\
\text { (Edifício- } \\
\text { Sede) }\end{array}$ \\
\hline $\begin{array}{c}\text { Consumo médio de água por pessoa considerando } \\
\text { sistemas de refrigeração (litros/pessoa/dia) no } \\
\text { conjunto de edifícios }\end{array}$ & 62,25 & & & 42,42 \\
\hline $\begin{array}{c}\text { Consumo médio de água por pessoa } \\
\text { (litros/pessoa/dia) com o uso de vasos sanitários no } \\
\text { conjunto de edifícios }\end{array}$ & & 21,96 & 29,00 & 13,24 \\
\hline $\begin{array}{c}\text { Consumo médio de água por pessoa } \\
\text { (litros/pessoa/dia) com o uso de torneiras de } \\
\text { lavatórios no conjunto de edifícios }\end{array}$ & & 4,558 & & 2,413 \\
\hline $\begin{array}{c}\text { Consumo médio de água por pessoa } \\
\text { (litros/pessoa/dia) em limpeza no conjunto de } \\
\text { edifícios }\end{array}$ & & 1,575 & & 1,069 \\
\hline Vazão das torneiras dos lavatórios (litros/segundo) & 0,113 & 0,090 & & 0,102 \\
\hline Vazão dos chuveiros (litros/segundo) & 0,095 & & & 0,132 \\
\hline $\begin{array}{l}\begin{array}{l}\text { Frequência de acionamentos dos vasos sanitários }\left(\mathrm{n}^{\circ}\right. \\
\text { vezes) }\end{array} \\
\end{array}$ & 2,852 & & $\begin{array}{l}3,4 \text { (masc.) } \\
7,1 \text { (fem.) }\end{array}$ & 3,263 \\
\hline Frequência de acionamentos dos mictórios ( ${ }^{\circ}$ vezes) & 3,119 & & 3,7 & 1,564 \\
\hline $\begin{array}{c}\text { Frequência de uso das torneiras dos lavatórios }\left(\mathrm{n}^{\circ}\right. \\
\text { vezes) }\end{array}$ & 4,181 & 5,325 & & 3,720 \\
\hline $\begin{array}{c}\text { Tempo de uso/funcionamento das torneiras dos } \\
\text { lavatórios (segundos) }\end{array}$ & 11,00 & 13,88 & & 6,180 \\
\hline Frequência de uso dos chuveiros ( $\mathrm{n}^{\circ}$ vezes) & 0,115 & & & 0,122 \\
\hline Tempo de uso dos chuveiros (segundos) & 45,318 & & & 78,352 \\
\hline Consumos de filtros de água (litros/pessoa/dia) & 0,500 & & & 0,565 \\
\hline $\begin{array}{c}\text { Representatividade do consumo de vasos sanitários } \\
\text { no consumo total do edifício }(\%)\end{array}$ & 47,7 & 63,68 & 54,88 & 60,81 \\
\hline $\begin{array}{l}\text { Representatividade do consumo de mictórios no } \\
\text { consumo total do edifício }(\%)\end{array}$ & 30,6 & & & 5,56 \\
\hline $\begin{array}{l}\text { Representatividade do consumo de torneiras de } \\
\text { lavatórios no consumo total do edifício }(\%)\end{array}$ & 14,15 & 14,05 & & 11,09 \\
\hline $\begin{array}{l}\text { Representatividade do consumo de lavagem de carros } \\
\text { no consumo total do edifício }(\%)\end{array}$ & 1,96 & & & $\begin{array}{c}8,45 \\
\text { (Anexo III) } \\
\end{array}$ \\
\hline $\begin{array}{c}\text { Representatividade do consumo com ar condicionado } \\
\text { no consumo total do edifício }(\%)\end{array}$ & 22,65 & & & $\begin{array}{l}10,24 \\
\text { (Edifício- } \\
\text { Sede) }\end{array}$ \\
\hline $\begin{array}{l}\text { Representatividade do consumo de limpeza no } \\
\text { consumo total do edifício }(\%)\end{array}$ & & 3,5 & & 19,04 \\
\hline $\begin{array}{c}\text { Representatividade do consumo do restaurante no } \\
\text { consumo total do edifício }(\%)\end{array}$ & 17,92 & & & 0,75 \\
\hline $\begin{array}{c}\text { Representatividade do consumo de usos não } \\
\text { identificados na pesquisa no consumo total do } \\
\text { edifício }(\%)\end{array}$ & 4,9 & 18,83 & & 7,46 \\
\hline $\begin{array}{l}\text { Representatividade do consumo de usos não potáveis } \\
\text { no consumo total do edifício }(\%)\end{array}$ & 77 & & 57,49 & 65,36 \\
\hline
\end{tabular}

Fontes: Kammers \& Ghisi (2006); Proença \& Ghisi (2009); Sant'Ana (2013) 
Pelos números supracitados, é possível chegar às seguintes conclusões:

- O consumo per capita do TCU está condizente com outros valores de pesquisas de usos finais de edifícios de usos equivalentes;

- O uso de equipamentos economizadores de água traz grande economia de consumo, da ordem de 39,7\% para vasos sanitários com caixa acoplada de duplo comando (comparados com os que possuem válvula de descarga) e $24,3 \%$ para torneiras de lavatórios com acionamento hidromecânico (comparadas com as de acionamento comum), igualando o número de usos diários por pessoa;

- Há necessidade urgente de se implantar um sistema de irrigação automatizada no TCU, que opere de modo eficiente e inteligente, preferencialmente interligado a sistemas de uso de fontes não potáveis de água;

- Fica ratificada a necessidade de adequação de procedimentos e a necessidade de eficiência dos sistemas e métodos de limpeza dos edifícios componentes do conjunto edificado do TCU, apesar da maior variedade de tipos de limpeza executada nesses locais;

- Foi acertada a decisão do TCU de optar por contratar empresa que faça a lavagem ecológica de veículos;

- O sistema de ar condicionado do TCU opera de forma eficiente.

\subsection{Síntese analítica do capítulo 5}

Os dados levantados na pesquisa foram suficientes para concluir que o consumo de água no conjunto edificado do TCU precisa ser reduzido em alguns pontos, devido especialmente:

- Ao volume consumido;

- Ao uso de tecnologias que merecem renovação;

- À necessidade de mudança de postura do usuário e das rotinas de manutenção e de limpeza dos ambientes;

- À necessidade de complementação do sistema de irrigação; e

- Aos possíveis resultados de pesquisa de viabilidade de implantação de sistemas de aproveitamento de águas pluviais e de tratamento de águas cinzas.

A metodologia aplicada à pesquisa se mostrou adequada para os fins a que se propôs e as etapas sugeridas por ANA et al. (2005) e MMA (2014), destacadas no Quadro 19 (p. 103), foram atendidas até onde foi possível, restando apenas uma avaliação econômica detalhada das recomendações elencadas no Quadro 29 (p. 187). 
No caso de a Política de Sustentabilidade do TCU ser aplicada com eficiência, tudo leva a crer que as ações recomendadas no plano de intervenção repercutirão positivamente no consumo de água em si e na conscientização dos usuários sobre a importância da água e a sua participação na preservação desse insumo para as próximas gerações.

O estudo de caso no Tribunal de Contas da União (TCU) foi detalhado de forma a refletir com a maior realidade possível o perfil dos usuários dos edifícios componentes do seu conjunto edificado, a saber: Edifício-Sede, Anexo I, Anexo II, Anexo III e Restaurante. Na maioria dos casos, foi possível definir com clareza a situação de gerenciamento dos edifícios, com acesso a dados fundamentais para a precisão dos resultados finais.

As informações acerca do número de usuários, áreas de edifícios e número de peças sanitárias foram levantadas com base em informações disponíveis no site do TCU ou nos arquivos de projetos de arquitetura do conjunto edificado. No caso de usos específicos de consumo de água na limpeza dos edifícios, na irrigação e no restaurante do TCU, foram aplicadas entrevistas estruturadas específicas, com participação dedicada dos gerentes.

No que concerne à manutenção dos edifícios, há que se ressaltar a preocupação da equipe com a redução do consumo e o detalhamento contratual de ações preventivas. Apesar dessas virtudes, a gestão ainda carece de avanços, como na fiscalização mais rigorosa dessas ações, treinamento adequado dos colaboradores e adoção de campanhas para a correção de uso de equipamentos pelos usuários.

Esses equipamentos, na sua maioria em ótimo estado de conservação, se mostraram bem especificados, mas sem iniciativa de pesquisas de atualização de tecnologias por parte do TCU. Quando da aferição de vazões e tempo de calibração das peças, não houve contratempos. As aferições de consumo nos hidrômetros, realizados pela equipe de manutenção hidráulica, para informar dados de irrigação e do restaurante, foram fundamentais para a clareza dos usos finais de água no TCU.

Os cálculos foram feitos para complementar as informações da pesquisa de usos dos equipamentos pelos usuários. Tal pesquisa, realizada de forma remota na maioria dos casos e respondidas em papel pelos usuários sem acesso à tecnologia da informação, chegou próximo de $45 \%$ da população total do TCU em Brasília/DF e, dentre esta parcela, foram respondidos $41 \%$ dos questionários, sendo aproveitados mais de $30 \%$ deles, de forma a se manter a proporcionalidade de respostas para cada tipo de usuário. Tal quantitativo foi considerado 
suficiente para representar a totalidade da população do TCU, com números próximos aos estudos de Marinoski e Ghisi (2008) e Kammers e Ghisi (2006).

Os usos finais foram calculados e separados os tipos de uso mais representativos, a saber: irrigação, equipamentos sanitários, limpeza, espelhos d'água, ar condicionado, lavagem de veículos e outros usos. Neste último caso, foram incluídos todos os consumos não identificados na presente pesquisa ou provenientes de vazamentos não identificados, imprecisão de respostas de entrevistas ou da pesquisa junto aos usuários, uso inadequado de sistemas e equipamentos, entre outros motivos.

A irrigação foi o sistema que mais consumiu água no complexo do TCU, com $41,68 \%$ da demanda, seguido dos equipamentos $(23,51 \%)$ e da limpeza $(19,04 \%)$. Gastos com lavagem de veículos, equipamentos de ar-condicionado e com o abastecimento do espelho d'água, entre outros, não foram relevantes. Com a implantação de um sistema automático completo de irrigação, há uma tendência futura de redução de valores absolutos e relativos de consumo.

Dentre os equipamentos, os usos finais mais relevantes foram os dos vasos sanitários, respondendo por $60,81 \%$ do consumo (31,70\% pelas descargas de 6 litros e $29,11 \%$ pelas descargas de 3 litros). As torneiras das copas e dos lavatórios também tiveram percentuais representativos, com 18,90\% e 11,09\%, respectivamente. Esses números mostraram que ainda há espaço para alguns ajustes de tecnologias, como o uso de mictórios sem água ou de restritores de vazão, por exemplo. Também deve ser dada atenção especial às rotinas de limpeza diária dos sanitários, evitando acionamentos de descargas desnecessários.

A auditoria apontou o perfil de consumo de água, que, juntamente com o referencial teórico levantado nos capítulos anteriores, culminou nas recomendações de ações da etapa do plano de intervenção. A avaliação do impacto da redução não foi contemplada nesta pesquisa. Ressalte-se que as sugestões elencadas nesta pesquisa serão apresentadas aos responsáveis da área administrativa e de engenharia do TCU.

Mesmo sem essa avaliação do impacto, infere-se que, dentre as ações elencadas no plano de intervenção proposto, a implantação de sistemas de aproveitamento de águas pluviais ou de tratamento de águas cinzas ou residuárias teriam maior potencial de impacto no consumo de água no TCU. Além destes, a modificação do sistema de irrigação, com possibilidade de execução em 2016, parece também ter chances de impactar no consumo, com significativa redução da demanda de água. 


\section{CAPÍTULO 6 - CONCLUSÕES}

O presente trabalho traz como contribuição, em primeiro lugar, recomendações à gestão hídrica de edifícios públicos no Brasil, tendo como fundamentação um referencial teórico que abrange as políticas públicas de uso eficiente da água e a legislação aplicável ao tema.

Em segundo lugar, complementando e fortalecendo a definição dessas recomendações, foi desenvolvido estudo de caso no Tribunal de Contas da União (TCU), com foco nas metodologias adotadas por ANA et al. (2005) e MMA (2014). Tais metodologias recomendam a aplicação de Programas de Conservação de Água (PCAs) nos edifícios, conforme síntese do Quadro 19 (p. 103). As fases definidas nessa síntese foram analisadas e seguidas no estudo de caso proposto, de forma a se verificar a pertinência da metodologia.

A revisão de literatura mostrou que a gestão hídrica brasileira está ancorada numa base legal ampla, bem detalhada e que tem a participação da população na tomada de decisões, de forma descentralizada e autônoma. Há iniciativas dispersas no Brasil, onde os agentes públicos incentivam a população a economizar a água em suas residências, bem como determinam a redução do consumo nos serviços públicos.

Também foi mostrada a caracterização dos edifícios públicos e das rotinas administrativas que envolvem a gestão pública, destacando seus aspectos legais e técnicos. Essa revisão demonstrou um suficiente amparo legal para a execução de Programas de Conservação de Água (PCAs), especialmente após a edição do Decreto Federal $n^{\circ} 7.746$, de 2012, quando foram regulamentados os Programas de Logística Sustentável na esfera pública, desburocratizados procedimentos para licitações públicas e autorizados especificadores técnicos a trabalharem com maior foco na sustentabilidade.

Por essa caracterização, foi possível concluir que a gestão de água nos edifícios públicos precisa passar por três pilares para se tornar eficiente: a diária e planejada manutenção periódica do edifício, com o monitoramento de equipamentos e sistemas; a conscientização dos usuários quanto à postura e consumo racional de água no seu ambiente de trabalho, com consequente propagação nas respectivas residências e nas iniciativas dos próprios familiares desses usuários; e a atualização constante de tecnologias conservadoras de água (TCAs), com o uso, sempre que economicamente viável, de aproveitamento da água da chuva e de tratamento de águas cinzas ou residuárias. 
Dessa forma, foram propostas recomendações de melhorias à legislação orientativa existente e às rotinas de gestão de edifícios públicos. No que concerne à primeira, vale destacar a possibilidade de:

- Revisão de políticas públicas para ampliação da oferta de água, com o comprometimento dos governos em todas as esferas de fazer com que a legislação existente e seus instrumentos avancem e sirvam de fato ao disciplinamento do acesso à água, dado que os níveis de desperdício das concessionárias se encontram em situação alarmante ${ }^{20}$;

- Ampliação da rede de controle de gestão dos entes públicos, avançando na cobrança de ações de impacto rápido e positivo na área de sustentabilidade;

- Planejamento e oferta de incentivos para a adoção de posturas inovadoras (como citado no Quadro 5 - p. 47), como o desenvolvimento de pesquisas de opinião anuais para obter o respaldo dos usuários das instalações públicas acerca da qualidade de vida no ambiente de trabalho, do desempenho da gestão predial e de ideias para o aprimoramento da administração;

- Desenvolvimento de novos estudos acerca da imposição de normativos que exijam a redução constante de consumo de água em edifícios públicos, baseados em indicadores nacionais;

- Separação de rubricas orçamentárias específicas para investimento dos gestores em ações de eficiência de desempenho de edifícios;

- Priorização de mudanças na Lei nº 8.666/1993 (Lei de Licitações Públicas) que tragam maior divulgação e transparência aos procedimentos licitatórios, ajuste dos limites de valores para as modalidades de licitação e vantagens para empresas que comprovem investimento em inovação e sustentabilidade, entre outras;

- Maior rigor e clareza na definição de critérios de qualificação técnica, operacional e financeira das empresas de engenharia;

- Discussão e criação de legislação compulsória para a execução de PCAs.

Independentemente da viabilidade econômica das soluções, parte-se do pressuposto que o poder público tem potencial interesse em investir em tecnologias inovadoras para economia de água em seu patrimônio edificado, dentro da disponibilidade orçamentária, das prioridades de gestão e das vantagens técnicas que os sistemas proporcionam. Se a filosofia da constante

\footnotetext{
${ }^{20}$ Dados do Sistema Nacional de Informações sobre Saneamento (SNIS, 2014) apontam que os níveis atuais de desperdício ao longo dos sistemas variam de $40 \%$ a $55 \%$ do volume total de água.
} 
vigilância na redução da demanda nos edifícios for perpetuada entre os gestores, os edifícios públicos brasileiros podem se tornar referências de gestão preditiva.

Por outro lado, o caráter político de que pode estar revestida uma decisão técnica na esfera pública pode provocar distorções dos resultados esperados em uma ação inovadora. É possível citar, como causas possíveis dessa eventual ineficiência de gestão pública de edifícios, entre outras:

- Corrupção dos agentes públicos;

- Cadeia de fornecedores com baixo controle de qualidade;

- Prazos curtos para desenvolvimento de projetos executivos e especificações técnicas;

- Baixa qualidade de execução proveniente de projetos mal desenvolvidos;

- Pouco investimento em reciclagem de servidores;

- Interesses políticos ou pessoais se sobrepondo aos de qualidade dos serviços públicos; e

- Falta de recursos orçamentários.

Em contraponto às causas acima, é recomendada a adoção de ajustes nas rotinas dos edifícios públicos. Tais propostas não são exaustivas e têm como foco a qualidade da gestão desses edifícios desde sua concepção, na fase de projetos, passando por toda sua execução até a fase pós-ocupação, especialmente a manutenção predial, como, por exemplo:

- Programação de palestras e cursos que esclareçam aos usuários dos edifícios os benefícios de medidas conservadoras de água;

- Formação de equipes (próprias ou contratadas) para projetos que realizem pesquisas prévias e detalhadas de fornecedores idôneos e que possuam soluções com vantagens comprovadas em relação à eficiência (hídrica e energética) dos produtos ou sistemas;

- Diálogo efetivo entre órgãos públicos que já aplicaram TCAs em seu patrimônio edificado, buscando informações acerca da confiabilidade, operacionalização e economia de água;

- Controle e fiscalização rigorosa no fornecimento dos insumos, partindo do pressuposto que serão bem especificados;

- Exigências de laudos que atendam às normas técnicas e de testes detalhados para a verificação do funcionamento das TCAs.

Outro ponto importante, na discussão do tema apresentado pela pesquisa, é a definição de parâmetros apropriados de usos de água no âmbito das edificações públicas, que poderá 
auxiliar e embasar outros programas de incentivo à economia de água, bem como auxiliar os organismos emissores de certificações e selos de eficiência de edificações a rever ou ratificar suas referências técnicas.

Outra ação relevante a ser destacada na gestão da água é a criação de programas de incentivos, com metas bem delimitadas e uso de indicadores para aferição do cumprimento dos objetivos. Os parâmetros adotados se mostraram em descompasso com a realidade internacional. Essa pesquisa, portanto, tenta trazer à realidade das recomendações brasileiras, consolidadas no Quadro 19 (p. 103), um vínculo com as políticas públicas de outros países, de forma que haja meios de comparação de desempenho no cenário internacional.

Foram disponibilizados mais indicadores no estudo de caso desenvolvido que o indicado na literatura brasileira. Essas publicações, de forma geral, têm recomendações similares às internacionais. Porém, destacam-se alguns aspectos a serem avaliados para incorporação aos métodos ali definidos:

- Possibilidade de modificação do caráter orientativo do texto para uma abordagem mais impositiva, especialmente no caso de edifícios públicos;

- Manutenção do indicador de população em litros/pessoa/dia e inclusão de indicadores de área útil nos edifícios em litros $/ \mathrm{m}^{2} / \mathrm{ano}$, de forma a comparar com padrões internacionais de desempenho;

- Desenvolvimento de pesquisas para a definição de indicadores regionalizados, respeitando as diferenças bioclimáticas e morfológicas das edificações;

- Estímulo ao uso de tecnologias de detecção eletrônica de vazões, como os data loggers, acelerando o processo de ampliação de pesquisas de usos finais de água em edifícios;

- Exigência de hidrometração setorizada em todos os edifícios públicos e comerciais em que não for possível a individualização, de forma a controlar a gestão de água e prevenir a ocorrência de vazamentos;

- Definição de redução continuada de metas de consumo de água nos edifícios públicos, com determinação de contrapartidas dos governos e prazos máximos de cumprimento, assim como definição de cortes orçamentários aos gestores que não atingirem as metas.

Não obstante a identificação de melhorias nos métodos aplicados no estudo de caso, a aplicação das recomendações brasileiras ao Tribunal de Contas da União (TCU) em Brasília/DF, cidade com densa participação de edifícios públicos em sua malha urbana, se 
mostrou adequada, tendo em vista que os dados detalhados estavam disponíveis ou foram aferidos diretamente nos pontos de consumo. A pesquisa reforçou conceitos como o de necessidade de maior planejamento de projetos, de forma que atendam à realidade da população que utilizará os edifícios, além de maior rigor na execução das obras, com utilização de materiais de qualidade e orçamento detalhado dos serviços.

O levantamento de dados mostrou, entre outros aspectos, na análise do consumo histórico de água, que a umidade relativa do ar média e precipitação média ao longo dos anos são fatores relevantes em um estudo de comportamento de consumo, conforme se depreende dos Gráficos 4 a 6 (pp. 150 a 153).

No caso da cidade de Brasília/DF, os meses de pouca umidade do ar, que coincidem com os de baixa precipitação, são inversamente proporcionais ao consumo de água nos edifícios públicos, podendo até este raciocínio ser estendido a qualquer tipologia edilícia desta cidade. Este fato pode ajudar a orientar equipes de manutenção em ações preventivas, bem como grupos de educação ambiental a atuarem de forma direcionada nas instituições públicas.

A auditoria de água trouxe informações relevantes que podem auxiliar na definição de um padrão de consumo de edifícios públicos administrativos no Brasil, conforme detalhado no Gráfico 12 (p. 178). O diagnóstico do conjunto edificado que foi pesquisado revelou a necessidade de atualização de alguns equipamentos sanitários, ajustes na rotina da equipe de manutenção predial e realização de ações de educação ambiental. Foram resumidos os indicadores de consumo de água levantados na pesquisa na Tabela 27 (p. 184), que também contribuirão para a consolidação de parâmetros em trabalhos futuros.

Os resultados apresentados nos Gráficos 13 e 14 (pp. 178 e 179) mostram que deve ser dada uma atenção especial aos consumos de água de irrigação, de equipamentos e de limpeza. As ações recomendadas no plano de intervenção, de acordo com o Quadro 29 (p. 187), pressupõem uma participação efetiva:

- Dos tomadores de decisão e autoridades, em nível gerencial;

- Dos gerentes técnicos das áreas afetadas, destacadamente os serviços gerais e a engenharia, em nível de planejamento e operacionalização; e

- Dos usuários dos edifícios, de todos as categorias pesquisadas, quanto à utilização e conscientização da necessidade de uso adequado dos equipamentos e sistemas, sempre com o objetivo de redução do consumo de água. 
Dessa forma, é possível concluir que este trabalho atingiu seus objetivos propostos e ratificou a hipótese inicialmente apresentada, de forma a afirmar que o regramento e as recomendações brasileiras de uso eficiente da água em edifícios públicos precisam de ajustes pontuais, com ênfase na atribuição de novos parâmetros de medição de eficiência hídrica dos edifícios públicos e estabelecimento de indicadores nacionais de consumo de água. Tais dados auxiliarão no estabelecimento de metas de consumo dessa tipologia de edifícios e na conscientização contínua dos usuários, replicando as boas práticas para toda a sociedade.

A presente pesquisa teve como limitações o pouco material encontrado na literatura acerca da gestão de água e de usos finais em edifícios públicos. Também houve dificuldades operacionais e políticas na obtenção dos dados do estudo de caso. Todavia, a quantidade de dados permitiu uma análise precisa e abrangente do comportamento dos usuários do TCU, que contribuirá para o avanço das pesquisas acadêmicas no tema de conservação e uso de água em edifícios públicos.

Como possibilidades de temas que podem ser abordados a partir dos discutidos nesta pesquisa, é possível destacar:

- Definição de indicadores regionais e nacionais de consumo de água em edifícios públicos;

- Definição de usos finais em edifícios públicos de funções distintas, como escolares, hospitalares, penitenciários e universitários, entre outros;

- Avaliação econômica de tecnologias conservadoras de água (TCAs) para uso em edifícios públicos;

- Aderência de instituições públicas aos Planos de Logística Sustentável e mudanças ocorridas após a edição do Decreto Federal no 7.746/2012 e da IN nº 2/2014, do MPOG. 


\section{REFERÊNCIAS BIBLIOGRÁFICAS}

ABNT - ASSOCIAÇÃO BRASILEIRA DE NORMAS TÉCNICAS. NBR 5626 - Instalações prediais de água fria. Rio de Janeiro. 1998. 41p.

. NBR 5674 - Manutenção de edificações - Requisitos para o sistema de gestão de manutenção. Rio de Janeiro. 2012.

. NBR 7198 - Instalações prediais de água quente. Rio de Janeiro. 1993. 6p.

. NBR 7229 - Projeto, construção e operação de sistemas de tanques sépticos. Rio de Janeiro. 1993. 15p.

. NBR 8009 - Hidrômetro taquimétrico para água fria até $15,0 \mathbf{~ m}^{3} / \mathrm{h}$ de vazão nominal - Terminologia. Rio de Janeiro. 1997.

. NBR 8160 - Sistemas prediais de esgoto sanitário. Rio de Janeiro. 1999. 74p.

. NBR 10844 - Instalações prediais de águas pluviais. Rio de Janeiro. 1989. 13p.

Janeiro. 2003.

NBR 10281 - Torneira de pressão - Requisitos e métodos de ensaio. Rio de

NBR 13713 - Instalações hidráulicas prediais - Aparelhos automáticos acionados mecanicamente e com ciclo de fechamento automático - Requisitos e métodos de ensaio. Rio de Janeiro. 2009.

NBR 13969 - Tanques sépticos - Unidades de tratamento complementar e disposição final dos efluentes líquidos - Projeto, construção e operação. Rio de janeiro. 1997. 60p.

NBR 14037 - Diretrizes para elaboração de manuais de uso, operação e manutenção das edificações - Requisitos para elaboração e apresentação dos conteúdos. Rio de Janeiro. 2011.

NBR 15527 - Água de chuva - Aproveitamento de coberturas em áreas urbanas para fins não potáveis - Requisitos. Rio de Janeiro. 2007. 8p.

NBR 15806 - Sistemas de medição predial remota e centralizada de consumo de água e gás. Rio de Janeiro. 2010.

ABRAMAN - ASSOCIAÇÃO BRASILEIRA DE MANUTENÇÃO. A situação da manutenção no Brasil - Documento Nacional 2013. Rio de Janeiro. 2013. Disponível em http://www.abraman.org.br/Arquivos/403/403.pdf. Acesso em maio de 2014.

AGUIAR, Carolina C.; GONÇALVES, Ricardo F. Potencial de conservação de água com a prática do reúso de águas cinzas e com o gerenciamento da urina humana em um edifício residencial. Encontro Latinoamericano de Comunidades Sustentáveis - ELECS. 
Vitória. 2011. Disponível em http://www.elecs2013.ufpr.br/wp-content/uploads/anais/2011/ 2011_artigo_124.pdf. Acesso em junho de 2014.

ALLEN, Lucy; CHRISTIAN-SMITH, Juliet; PALANIAPPAN, Meena. Overview of greywater reuse: The potential of greywater systems to aid sustainable water management. California Pacific Institute. Oakland/USA. 2010. Disponível em http://www. pacinst.org/wp-content/uploads/sites/21/2013/02/greywater_overview3.pdf. Acesso em agosto de 2014.

ALMEIDA, Hilda M. Campanha de conscientização de usuários quanto ao uso racional de água no campus VI do CEFET/MG. Dissertação (Mestrado em Engenharia Civil). Universidade Federal de Santa Catarina. Florianópolis. 2009. Disponível em https:// repositorio.ufsc.br/bitstream/handle/123456789/92763/278396.pdf?sequence=1. Acesso em setembro de 2013.

ALMEIDA, Rodrigo G. Aspectos Legais para a água de reúso. Revista Vértices, Campos dos Goytacazes/RJ. Vol.13, n.2, p. 31-43, 2011. Disponível em http://essentiaeditora.iff.edu. br/index.php/vertices/article/viewFile/1809-2667.20110012/701. Acesso em abril de 2014.

ALTONIAN, Cláudio S. Obras públicas - licitação, contratação, fiscalização e utilização. Belo Horizonte: Editora Fórum, 4ª ed., 2014. 539p.

ALVES, Renato V. R. Uso eficiente da água em edifícios. Dissertação (Mestrado em Engenharia Civil). Universidade do Porto - FEUP. Porto (Portugal). 2010. Disponível em repositorio-aberto.up.pt/bitstream/10216/59652/1/000143426.pdf. Acesso em abril de 2014.

ANA - AGÊNCIA NACIONAL DE ÁGUAS. Disponibilidade e Demandas de Recursos Hídricos no Brasil. Brasília. 2005.

Água - fatos e tendências. Brasília. 2009.

Portal da Qualidade das Águas. Disponivel em: <http://pnqa.ana.gov.br lenquadramento-bases-conceituais.aspx>. Acesso em: setembro 2014.

Conjuntura do Recursos Hídricos - Encarte Especial sobre a Crise Hídrica. Brasília. 2015.

Conjuntura dos Recursos Hídricos no Brasil - Informe 2014. Brasília. 2015.

ANA; FIESP; SINDUSCON-SP. Conservação e Reúso de Água em Edificações. São Paulo. 2005. Disponível em http://www.sindusconsp.com.br/downloads/prodserv/publicacoes /manual_agua_em_edificacoes.pdf. Acesso em julho de 2013.

ANAO - AUSTRALIAN NATIONAL AUDIT OFFICE. Reducing the environmental impacts of public sector operations. Public Sector Environmental Management. Canberra. 2012. Disponível em http://www.anao.gov.au/Publications/Better-Practice-Guides/20112012/Public-Sector-Environmental-Management. Acesso em setembro de 2014. 
AUSTRALIAN GOVERNMENT. Water efficiency guide: office and public buildings. Department of the Environment and Heritage. Canberra. 2006. Disponível em http://www. environment.gov.au/resource/water-efficiency-guide-office-and-public-buildings. Acesso em julho de 2014.

AWE - ALLIANCE FOR WATER EFFICIENCY. Watersmart Guidebook - A water-use efficiency plan-review guide. East Bay. 2008. Disponível em http://www. allianceforwaterefficiency.org/WaterSmart_Guidebook_for_Businesses.aspx. Acesso em agosto de 2014.

AYUNTAMIENTO DE MADRID. Plan municipal de gestión de la demanda del agua en la ciudad de Madrid. Madrid. 2005. Disponível em http://www.madrid.es/ UnidadWeb/Contenidos/Publicaciones/TemaMedioAmbiente/PlanDemandaAgua/plan\%20del \%20agua.pdf. Acesso em setembro de 2014.

BANNISTER, Paul; MUNZINGER, Michael; BLOOMFIELD, Chris. Water benchmarks for offices and public buildings. Belconnen. 2005. Disponível em http://www.environment.gov.au/system/files/resources/87e47d24-8519-4582-8ec2d39746297643/files/water-benchmarks.pdf. Acesso em novembro de 2014.

BARATA, Martha M. L.; KLIGERMAN, Débora C.; MINAYO-GOMEZ, Carlos. A gestão ambiental no setor público: uma questão de relevância social e econômica. Ciência e Saúde Coletiva, Rio de Janeiro, Vol. 12, n. 1, jan/mar 2007. Disponível em: http://www.scielo.br/pdf/csc/v12n1/15.pdf. Acesso em fevereiro de 2013.

BIBIANO, Márcia H. Sustentabilidade Hídrica de Edifícios Habitacionais. Dissertação (Mestrado em Engenharia Civil). Instituto Superior de Engenharia de Lisboa. Lisboa. 2013. Disponível em http://repositorio.ipl.pt/bitstream/10400.21/2166/1/Disserta\%C3\%A7\%C3\% B5es.pdf. Acesso em agosto de 2013.

BINT, Lee; VALE, Robert; ISAACS, Nigel. Water performance benchmarks for New Zealand: an approach to understanding water consumption in commercial office buildings. Victoria University of Wellington. Wellington. 2005. Disponível em http://www.branz.co.nz/cms_show_download.php? id=75d24. Acesso em novembro de 2014.

Water efficiency in office buildings. In: Water efficiency in buildings - theory and practice (pp.241-251). ADEYEYE, Kemi (org.). Oxford. 2014.

BIRKS, Rebecca; HILLS, Sian. Characterisation of indicator organisms and pathogens in domestic greywater for recycling. Environmental Monitoring and Assessment, v. 129, n. 13, p. 61-69. Reading/UK, Fevereiro 2007. Disponível em http://www.unc.edu/courses/ 2007spring/envr/890/003/readings/indicators_pathogens_greywater_2007.pdf. Acesso em novembro de 2014.

BLUMENAU. Lei $\mathbf{n}^{\mathbf{0}}$ 5.935, de 24 de junho de 2002. Blumenau/SC. 2002. Dispõe sobre o consumo de água em novos prédios públicos e privados. 
Lei Complementar $\mathbf{n}^{0}$ 902, de 28 de agosto de 2013. Dispõe sobre a instalação de hidrômetros individuais nos edifícios residenciais dos programas habitacionais no município de Blumenau. Blumenau. 2013.

BLUMENSCHEIN, Raquel N. A sustentabilidade na cadeia produtiva da indústria da construção. Centro de Desenvolvimento Sustentável - CDS. Universidade de Brasília - UnB. Brasília. 2004.

BRASIL. Decreto Federal $\mathbf{n}^{\circ}$ 24.643, de 10 de julho de 1934. Decreta o Código de Águas. Rio de Janeiro. 1934.

Lei $\mathbf{n}^{\mathbf{0}}$ 6.983, de 31 de agosto de 1981. Dispõe sobre a Política Nacional do Meio Ambiente, seus fins e mecanismos de formulação e aplicação, e dá outras providências. Brasília. 1981. Brasília. 1988.

Constituição da República Federativa do Brasil, de 5 de outubro de 1988.

Lei $n^{0}$ 8.666, de 21 de junho de 1993. Regulamenta o art. 37, inciso XXI, da Constituição Federal, institui normas para licitações e contratos da Administração Pública e dá outras providências. Brasília. 1993.

Lei $\mathbf{n}^{\mathbf{0}}$ 9.433, de 8 de janeiro de 1997. Institui a Política Nacional de Recursos Hídricos. Brasília. 1997.

Lei $\mathrm{n}^{\circ}$ 9.605, de 12 de fevereiro de 1998. Dispõe sobre as sanções penais e administrativas derivadas de condutas e atividades lesivas ao meio ambiente, e dá outras providências. Brasília. 1998.

Lei $\mathbf{n}^{\mathbf{0}}$ 11.445, de 5 de janeiro de 2007. Estabelece diretrizes nacionais para o saneamento básico. Brasília. 2007.

Decreto Federal $n^{0}$ 6.514, de 22 de julho de 2008. Dispõe sobre as infrações e sanções administrativas ao meio ambiente, estabelece o processo administrativo federal para apuração destas infrações, e dá outras providências. Brasília. 2008.

Decreto Federal $\mathbf{n}^{\mathbf{0}}$ 7.217, de 21 de junho de 2010. Regulamenta a Lei no 11.445, de 5 de janeiro de 2007, que estabelece diretrizes nacionais para o saneamento básico, e dá outras providências. Brasília. 2010.

Decreto Federal $\mathbf{n}^{\mathbf{0}} \mathbf{7 . 7 4 6}$, de 5 de junho de 2012. Estabelece critérios, práticas e diretrizes para a promoção do desenvolvimento nacional sustentável nas contratações realizadas pela administração pública federal. Brasília. 2012.

BRAVER, Deborah; TANNER, Stephanie. Implementing water conservation goals at federal facilities - lessons learned. In: Water sources conference: reuse, researches and 
conservation. Nevada Renewable Energy Laboratory. Las Vegas. 2002. Disponível em http://www.nrel.gov/docs/fy02osti/31303.pdf. Acesso em julho de 2014.

BREEAM - BUILDING RESEARCH ESTABLISHMENT ENVIRONMENTAL ASSESSMENT METHOD. BREEAM scheme document for new construction - nondomestic buildings. Londres. 2013.

BUILDING OWNERS AND MANAGERS ASSOCIATION OF CANADA. BOMA buiding environmental standards 2013. Otawa. 2013. Disponível em http://www.bomabest.com/wpcontent/uploads/BBEER-2013-Full-Report.pdf. Acesso em agosto de 2014.

BURSZTYN, Marcel. Ciência, Ética e Sustentabilidade. Brasília. 2001. Disponível em http://www.sel.eesc.sc.usp.br/informatica/graduacao/material/etica/private/ciencia_etica_e_su stentabilidade_unesco.pdf. Acesso em julho de 2012.

CAESB - COMPANHIA DE SANEAMENTO AMBIENTAL DO DISTRITO FEDERAL. Norma ND.SCO-013, de 20 de dezembro de 2012. Sistemas de Reuso de Água e de Aproveitamento de Água Pluvial. Brasília. 2012.

CAMPINAS. Lei Complementar $\mathbf{n}^{\circ}$ 13, de 4 de maio de 2006. Dispõe sobre obrigatoriedade de instalação de hidrômetros em cada unidade autônoma dos condomínios em geral e dá outras providências. Campinas/SP. 2006.

CARlino, Alex E. Melhorias dos Processos de Manutenção em Prédios Públicos. Dissertação (Mestrado) - Universidade Federal de São Carlos. São Carlos. 2012. Disponível em http://www.bdtd.ufscar.br/htdocs/tedeSimplificado/tde_arquivos/7/TDE-2012-0910T171645Z-4586/Publico/4472.pdf. Acesso em abril de 2014.

CBCS - CONSELHO BRASILEIRO DE CONSTRUÇÃO SUSTENTÁVEL. Avaliação das tecnologias existentes no mercado e soluções para melhorar a eficiência energética e o uso racional da água em Habitação de Interesse Social no Brasil. Projeto SUSHI (Sustainable Social House Initiative). Brasília. 2010. Disponível em http://www.cbcs.org.br /sushi/images/relatorios/Final_Brazil_reports_160511/3_Avaliacao_120511.pdf. Acesso em novembro de 2013.

CBIC - CÂMARA BRASILEIRA DA INDÚSTRIA DA CONSTRUÇÃO. A Produtividade da Construção Civil Brasileira. Brasília. 2012. Disponível em http://www.cbicdados.com. br/media/anexos/066.pdf. Acesso em setembro de 2012.

Notícia extraída do site corporativo. Disponivel em: <http://www.cbicdados. com.br/menu/pib-e-investimento/pib-brasil-e-construcao-civil>. Acesso em: fevereiro de 2013.

CETESB - COMPANHIA AMBIENTAL DO ESTADO DE SÃO PAULO. Histórico da legislação hídrica no Brasil. São Paulo. 2010. Disponível em 
http://www.cetesb.sp.gov.br/agua/\%C3\%81 guas-Superficiais/38-Historico-daLegisla\%C3\%A7\%C3\%A3o-H\%C3\%ADdrica-no-Brasil\#. Acesso em março de 2013.

CNRH - CONSELHO NACIONAL DE RECURSOS HÍDRICOS. Resolução n⿳ 54, de 28 de novembro de 2005. Estabelece modalidades, diretrizes e critérios gerais para a prática de reuso direito não potável de água e dá outra providências. Brasília. 2005.

Resolução CNRH no 135, de 14 de dezembro de 2011. Aprova o documento "Plano Nacional de Recursos Hídricos: Prioridades 2012:2015" como resultado da primeira revisão do PNRH. Brasília. 2011.

COELHO, Adalberto C. A medição de água individualizada: manual do condomínio. Olinda/PE: Luci Artes Gráficas, 2004.

COELHO, Adalberto C.; MAYNARD, João C. B. Medição Individualizada de apartamentos em edifícios multi-familiares. In: Anais do $19^{\circ}$ Congresso Brasileiro de Engenharia Sanitária e Ambiental. Foz do Iguaçu/PR, p. 1048-1059. 1997. Disponível em http://www.bvsde.paho.org/bvsacd/abes97/edificios.pdf. Acesso em setembro de 2014.

CONAMA - CONSELHO NACIONAL DO MEIO AMBIENTE. Resolução CONAMA no 357, de 17 de março de 2005. Dispõe sobre a classificação dos corpos de água e diretrizes ambientais para o seu enquadramento, bem como estabelece as condições e padrões de lançamento de efluentes, e dá outras providências. Brasília. 2005.

CUNHA, Vanessa D. Estudo para proposta de critérios de qualidade da água para reúso urbano. Dissertação (Mestrado) - Escola Politécnica da Universidade de São Paulo. São Paulo. 2008. Disponível em http://www.teses.usp.br/teses/disponiveis/3/3147/tde-02022009182058/pt-br.php. Acesso em julho de 2013.

CURITIBA. Lei $\mathbf{n}^{\mathbf{0}} \mathbf{1 0 . 7 8 5}$, de 18 de setembro de 2003. Cria, no município de Curitiba, o programa de conservação e uso racional da água nas edificações - PURAE. Curitiba. 2003.

DANTAS, Danniely L.; SALES, Alessander W. C. Aspectos ambientais, sociais e jurídicos do reuso da água. Revista de Gestão Social e Ambiental. Set / Dez 2009, v.3, no 3, p. 4-19, São Paulo, 2009. Disponível em http://www.revistargsa.org/rgsa. Acesso em abril de 2013.

DISTRITO FEDERAL. Lei n $^{\mathbf{0}}$ 41, de 13 de setembro de 1989. Dispõe sobre a Política Ambiental do Distrito Federal e dá outras providências. Brasília. 1989.

Lei no 2.616, de 26 de outubro de 2000. Dispõe sobre a utilização de equipamentos economizadores de água nas instalações hidráulicas e sanitárias dos edifícios públicos e privados de uso não residencial no âmbito do Distrito Federal. Brasília. 2000.

Lei $\mathbf{n}^{\mathbf{0}}$ 2.725, de 13 de junho de 2001. Institui a politica de recursos hídricos e cria o Sistema de Gerenciamento de Recursos Hídricos do Distrito Federal. Brasília. 2001. 
Lei no 4.181, de 21 de julho de 2008. Cria o Programa de Captação de Água da Chuva e dá outras providências. Brasília. 2008.

Lei $\mathbf{n}^{\mathbf{0}}$ 4.383, de 28 de julho de 2009. Altera a Lei $\mathrm{n}^{\circ} 3.557$, de 18 de janeiro de 2005, que dispõe sobre a individualização de instalação de hidrômetro nas edificações verticais residenciais e nas de uso misto e nos condomínios residenciais do Distrito Federal, e dá outras providências. Brasília. 2009.

Lei $n^{0}$ 4.671, 10 de novembro de 2011. Dispõe sobre a obrigatoriedade da instalação de reservatórios de captação de água para as unidades habitacionais do Distrito Federal e dá outras providências. Brasília. 2011.

DWORAK, Thomas et al. EU water saving potential - Final report. Ecologic - Institute for International and European Environmental Policy. Berlim. 2007. Disponível em http://watereurope.org/documents/EU\%20Water\%20saving\%20potential\%20(Part\%201).pdf. Acesso em agosto de 2013.

DZIEGIELEWSKI, Benedykt et al. Commercial and institutional end uses of water. AWWA Research Foundation. Denver. 2000. Disponível em http://ufdc.ufl.edu /WC13511002/00001. Acesso em setembro de 2013.

EBC. Empresa Brasil de Comunicação. ONU: população precisará de $40 \%$ a mais de água em 2030. Disponivel em: <http://agenciabrasil.ebc.com.br/geral/noticia/2014-03/onupopulacao-precisara-de-40-mais-de-agua-em-2030>. Acesso em: abril de 2014.

ENVIRONMENT DIRECTORATE-GENERAL OF THE EUROPEAN COMMISSION. Water performance of buildings - background paper for the steakholder consultation. Bruxelas. 2011. Disponível em http://ec.europa.eu/environment/consultations/pdf. Acesso em agosto de 2014.

EPA - UNITED STATES ENVIRONMENTAL PROTECTION AGENCY. Guidelines for water reuse. Washington. 2012. Disponível em http://nepis.epa.gov/Adobe/PDF /P100FS7K.pdf. Acesso em maio de 2014.

ERIKSSON, Eva et al. Characteristics of grey wastewater. Urban Water, v. 4, pp. 85-104. Londres, 2002. Disponível em http://www.researchgate.net/publication/257587685_ Characteristics_of_grey_wastewater. Acesso em janeiro de 2015.

ESTADO DE MINAS GERAIS. Lei Estadual $\mathbf{n}^{\mathbf{0}} \mathbf{1 7 . 5 0 6}$, de 29 de maio de 2008. Dispõe sobre a medição individualizada do consumo de água nas edificações prediais verticais. Belo Horizonte. 2008.

ESTADO DE PERNAMBUCO. Lei Estadual no 12.609, de 22 de junho de 2004. Institui a obrigatoriedade da instalação de hidrômetros individuais nos edifícios no Estado de Pernambuco. Recife. 2004. 
ESTADO DE SÃO PAULO. Decreto Estadual no $\mathbf{4 8 . 1 3 8 , ~ d e ~} 7$ de outubro de 2003. Institui medidas de redução de consumo e racionalização do uso de água no âmbito do Estado de São Paulo. São Paulo. 2003.

Lei $\mathbf{n}^{\mathbf{0}}$ 12.526, de 02 de Janeiro de 2007. Estabelece normas para a contenção de enchentes e destinação de águas pluviais. São Paulo. 2007.

FALKENMARK, M. Meeting Water Requirements of an Expanding World Population. Philosophical Transactions B of the Royal Society. Pg. 929-936. Londres. 1997. Disponível em http://www.ncbi.nlm.nih.gov/pmc/articles/PMC1691983/pdf/KLVLWQ8ET9HXH4HT _352_929.pdf. Acesso em setembro de 2013.

FARIA, Edimur F. Curso de Direito Administrativo Positivo. $7^{\text {a }}$. ed. Belo Horizonte: Del Rey, 2011.

FASOLA, Gabriel B. et al. Potencial de economia de água em duas escolas em Florianópolis, SC. Revista Ambiente Construído, v. 11, n. 4, out./dez. 2011. Porto Alegre. 2011. Disponível em http://seer.ufrgs.br/ambienteconstruido/article/view/22715. Acesso em junho de 2014.

FLORENCIO, Lourdinha; BASTOS, Rafael K. X.; AISSE, Miguel M. Tratamento e utilização de esgotos sanitários - Projeto PROSAB. Associação Brasileira de Engenharia Sanitária. Rio de Janeiro. 2006.

FLORIANÓPOLIS. Lei Complementar $\mathbf{n}^{\mathbf{0}}$ 171, de 9 de junho de 2005. Inclui $\S 6^{\circ}$ no art. 218 da Lei Complementar $n^{\circ}$ 060/2000. Florianópolis. 2005.

Lei $\mathbf{n}^{0}$ 8.080, de 07 de dezembro de 2009. Institui programa municipal de conservação, uso racional e reuso da água em edificações e dá outras providências. Florianópolis. 2009.

FYFE, Julian et al. City of Sidney Decentralised Water Master Plan - Part 1: Water Efficiency Plan. University of Sidney Technology - Institute for Sustainable Futures. Sidney. 2012. Disponível em http://www.cityofsydney.nsw.gov.au/_data/assets/pdf_file/0006/ 151179/Exhibition-Report-Water-Efficiency-Plan-120502.PDF. Acesso em abril de 2015.

GHISI, Enedir. Instalações de água fria. Apostila da disciplina Instalações I. Universidade Federal de Santa Catarina. Florianópolis. 26p. 2004.

GIACCHINI, Margolaine. Uso e Reuso da Água. Série de Cadernos Técnicos do Conselho Regional de Engenharia e Agronomia do Paraná (CREA-PR). Curitiba. 2011. Disponível em ftp://creaweb.crea-pr.org.br/_Cadernos_Ag_Parlamentar/usoreuso.pdf. Acesso em agosto de 2013.

GOMES JÚNIOR, Jarém G. Gerenciamento de projetos de engenharia de manutenção em edifícios públicos: uma abordagem transdisciplinar. Dissertação (mestrado) Universidade Federal de Minas Gerais. Belo Horizonte. 2012. Disponível em 
http://www.bibliotecadigital.ufmg.br /dspace/handle/1843/ISMS-8VGLYM. Acesso em setembro de 2013.

GONÇALVES, Orestes M. Evolução e Tendências dos Sistemas Hidráulicos Prediais. Palestra proferida no $4^{\circ}$ Seminário Tecnologia de Sistemas Prediais do Sindicato da Indústria da Construção Civil de São Paulo (SINDUSCON-SP). São Paulo. 2007. Disponível em http://www.sindusconsp.com.br/downloads/eventos/2007/4sis_prediais/orestes_gonsalves.pdf . Acesso em fevereiro de 2014.

GONÇALVES, Ricardo F. Conservação de água e energia em sistemas prediais e públicos de abastecimento de água. Associação Brasileira de Engenharia Sanitária. Programa de Pesquisa em Saneamento Básico - PROSAB 5 - Caderno 5. Rio de Janeiro. 2009. Disponível em http://www.finep.gov.br/images/apoio-e-financiamento/historico-de-programas/prosab/ prosab5_tema_5.pdf. Acesso em junho de 2015.

GOVERNMENT OF INDIA. General guidelines for water audit \& water conservation. Ministry of Water Resources. Nova Dheli. 2005. Disponível em http://india.gov.in/generalguidelines-water-audit-water-conservation-ministry-water-res. Acesso em agosto de 2014.

Water Audit for Centre for Science and Environment. Ministry of Urban Development. Centre for Science and Environment. Nova Dheli. 2011. Disponível em http://www.cseindia.org/content/cse-building-water-audit. Acesso em agosto de 2014.

GREGOTTI, Vittorio. Território da Arquitetura. Série Debates - Arquitetura. Rio de Janeiro: Editora Perspectiva, $3^{\mathrm{a}}$ ed., 2001. 188p.

GUARULHOS. Lei $\mathbf{n}^{\mathbf{0}}$ 6.793, de 28 de dezembro de 2010. Dispõe sobre o lançamento, arrecadação e fiscalização do Imposto Sobre a Propriedade Predial e Territorial Urbana IPTU e dá outras providências. Guarulhos. 2010.

HAFNER, Ana V. Conservação e reúso de água em edificações - experiências nacionais e internacionais. Dissertação (Mestrado em Engenharia Civil). Universidade federal do Rio de Janeiro - UFRJ. Rio de Janeiro. 2007. Disponível em http://wwwp.coc.ufrj.br /teses/mestrado/rh/2007/Teses/HAFNER_AV_07_t_M_rhs.pdf. Acesso em setembro de 2013.

HENZE, Mogens; LEDIN, Anna. Types, characteristics and quantities of classic, combined domestic wastewaters. In: Decentralised sanitation and reuse: concepts, systems and implementation. Chapter 4. IWA Publishing. p. 59-72. Londres. 2001.

HERNANDES, André T. Diretrizes para o gerenciamento de água pluvial nas edificações escolares municipais da cidade de Ribeirão Preto. Dissertação (Mestrado em Construção Civil), Universidade Federal de São Carlos. São Carlos. 2006. Disponível em http://www.bdtd.ufscar.br/htdocs/tedeSimplificado/tde_busca/processaPesquisa.php?pesqExe cutada=1\&id=1297. Acesso em julho de 2013. 
HESPANHOL, Ivanildo; MAY, Simone. Tratamento de águas cinzas claras para reúso não potável em edificações. REGA - Revista de Gestão de Água da América Latina, Porto Alegre/RS, Vol.5, no 2, pp. 15-24, jul/dez 2008.

HOLANDA, Marcos A. A. G. Medição Individualizada em edifícios residenciais: controle e redução do consumo de água potável. Universidade Católica de Pernambuco. Dissertação (Mestrado em Engenharia Civil). Recife. 2007. Disponível em http://www.unicap.br/tede /tde_busca/arquivo.php?codArquivo=168. Acesso em setembro de 2013.

IBGE - INSTITUTO BRASILEIRO DE GEOGRAFIA E ESTATÍSTICA. Pesquisa Anual da Indústria da Construção - PAIC 2012. Rio de Janeiro. 2014.

ITABIRA. Lei $\mathbf{n}^{\mathbf{0}} \mathbf{4 . 5 2 4}$, de 16 de abril de 2012. Dispõe sobre a obrigatoriedade de instalação de hidrômetro, por unidade autônoma, residencial ou comercial, em edificações no Município. Itabira/MG. 2012.

JUSTEN FILHO, Marçal. Parecer elaborado pelo Professor Doutor Marçal Justen Filho versando sobre a o anteprojeto da Lei da Política Nacional de Saneamento Básico. Curitiba. 2005. Disponível em http://www.planalto.gov.br/ccivil_03/revista/Rev_72/pareceres /saneamento_complementar_MarcalJustenFilho_1.pdf. Acesso em março de 2014.

KALBUSCH, Andreza; GONÇALVES, Orestes M. Critérios de Avaliação de Sustentabilidade Ambiental dos Sistemas Prediais Hidráulicos e Sanitários em Edifícios de Escritórios. Boletim Técnico da Escola Politécnica da USP BT/PCC/467. São Paulo. 2007. Disponível em http://www.pcc.usp.br/files/text/publications/BT_00467.pdf. Acesso em outubro de 2013.

KAMMERS, Pauline C.; GHISI, Enedir. Usos Finais de Água em Edifícios Públicos Localizados em Florianópolis, SC. Ambiente Construído, v. 6, n. 1, p. 75-90, jan./mar. 2006. Porto Alegre. 2006. Disponível em http://seer.ufrgs.br/ ambienteconstruido/article/ viewFile/3681/2047. Acesso em julho de 2013.

KITCHEN, Neil; ROONEY, Elaine; WHITEHOUSE, Godfrey. Final Watermark Project Report. Office of Government Commerce. Londres. 2003. Disponível em http:// coloradowaterwise.org/Resources/Documents/ICI_toolkit/docs/ppab06/uk-final-report.pdf.

Acesso em outubro de 2013.

LAGE, Epaminondas S. Aproveitamento de água pluvial em concessionárias de veículos em Belo Horizonte: potencial de economia de água potável e estudo de viabilidade econômica. Universidade Federal de Santa Catarina - UFSC. Dissertação (Mestrado em Engenharia Civil). Florianópolis. 2010. Disponível em http://www.labeee.ufsc.br/node/199. Acesso em outubro de 2013.

LEUCK, Monica F. Avaliação econômica do impacto de medidas individualizadas de conservação de água em Porto Alegre. Dissertação (Mestrado em Recursos Hídricos e Saneamento Ambiental), Universidade Federal do Rio Grande do Sul. Porto Alegre. 2008. 
Disponível em http://www.bibliotecadigital.ufrgs.br/ da.php?nrb=000698789\&loc $=2009 \& 1=$ 540b8697e884608a. Acesso em outubro de 2013.

MANCUSO, Pedro C. S.; SANTOS, Hilton F. Reuso de Água. Núcleo de Informações em Saúde Ambiental. Universidade de São Paulo. Barueri: Ed. Manole, 2003.

MARINGÁ. Lei $\mathbf{n}^{\mathbf{0}} \mathbf{6 . 3 4 5}$, de 15 de outubro de 2003. Institui o programa de reaproveitamento de águas de Maringá. Maringá. 2003.

Lei $\mathbf{n}^{\circ}$ 6339, de 15 de outubro de 2003. Dispõe sobre a instalação de dispositivos hidráulicos destinados ao controle e à redução do consumo de água e dá outras providências. Maringá. 2003.

MARINOSKI, Ana K.; ANDRADE, Márcio. Componentes hidráulicos economizadores de água. In: LAMBERTS et al. (orgs.). Casa Eficiente: uso racional da água. LabEEE. Universidade Federal de Santa Catarina. Florianópolis. 2010. Disponível em http://www.labeee.ufsc.br/sites/default/files/publicacoes/livros/CasaEficiente_vol_III_WEB.p df. Acesso em novembro de 2013.

MARINOSKI, Ana K.; GHISI, Enedir. Aproveitamento de água pluvial para usos não potáveis em instituição de ensino: estudo de caso em Florianópolis - SC. Ambiente Construído, v. 8, n. 2, p. 67-84, abr./jun. 2008. Porto Alegre. 2008. Disponível em http://seer.ufrgs.br/index.php/ambienteconstruido/article/view/5355/3283. Acesso em outubro de 2013.

MARTÍNEZ, Clara I. P. Selección de tecnologias limpias. Universidad Nacional Abierta y a Distancia. Bogotá. 2012. Disponível em http://datateca.unad.edu.co/contenidos /358029/ContenidoLinea/index.html. Acesso em novembro de 2013.

MAY, Simone. Caracterização, tratamento e reúso de águas cinzas e aproveitamento de águas pluviais em edificações. Escola Politécnica da Universidade de São Paulo. Tese (Doutorado em Engenharia). São Paulo. 2009. Disponível em http://www.teses.usp.br/teses/ disponiveis/3/3147/tde-17082009-082126/pt-br.php. Acesso em agosto de 2013.

MAYER, Peter W. et al. National multiple family submetering and allocation billing program study. US Environmental Protection Agency - EPA. Washington. 2004.

MCTI. Estratégia Nacional de Ciência, Tecnologia e Inovação 2012-2015. Brasília. 2012.

MINISTÉRIO DA SAÚDE. Portaria MS n 518, de 25 de março de 2004. Estabelece os procedimentos e responsabilidades relativos ao controle e vigilância da qualidade da água para consumo humano e seu padrão de potabilidade, e dá outras providências. Brasília. 2004.

Portaria $\mathbf{n}^{0}$ 2.914, de 12 de dezembro de 2011. Dispõe sobre os procedimentos de controle e de vigilância da qualidade da água para consumo humano e seu padrão de potabilidade. Brasília. 2011. 
MINISTÉRIO DAS CIDADES. PNCDA - Programa Nacional de Combate ao Desperdício de Água. Secretaria Nacional de Saneamento Ambiental. Brasília. 1999.

Diagnóstico dos Serviços de Água e Esgotos 2013. Sistema Nacional de Informações sobre o Saneamento (SNIS). Brasília. 2014. Disponível em http:// www.snis.gov.br/PaginaCarrega.php?EWRErterterTERTer=103. Acesso em maio de 2014.

MINISTÉRIO DO MEIO AMBIENTE. A3P - Agenda Ambiental na Administração Pública. Brasília. 2000. Disponível em http://www.mma.gov.br/responsabilidadesocioambiental/a3p. Acesso em janeiro de 2015.

Manual Prático para Conservação de Água em Edifícios Públicos. Secretaria de Articulação Institucional e Cidadania Ambiental. Brasília. 2014.

MORELLI, Eduardo B. Reuso de água na lavagem de veículos. Dissertação (Mestrado em Engenharia). Universidade de São Paulo. São Paulo. 2005. Disponível em http://www.tratamentodeagua.com.br/r10/Lib/Image/art_1120048943_reuso_de_agua_de_lav agem_de_veiculos.pdf. Acesso em agosto de 2013.

MPOG - MINISTÉRIO DO PLANEJAMENTO, ORÇAMENTO E GESTÃO. Manual de Obras Públicas - Edificações, Manutenção e Projeto. Volumes I, II e III. Secretaria de Estado da Administração e Patrimônio - SEAP. Brasília. 1997.

Instrução Normativa $n^{0}$ 10, de 12 de novembro de 2012. Secretaria de Logística e Tecnologia da Informação - SLTI. Estabelece regras para elaboração dos Planos de Gestão de Logística Sustentável de que trata o art. 16, do Decreto n ${ }^{\circ} 7.746$, de 5 de junho de 2012. Brasília. 2012.

Instrução Normativa $n^{0}$ 2, de 4 de junho de 2014. Dispõe sobre regras para a aquisição de máquinas e aparelhos consumidores de energia pela Administração Pública Federal e uso da Etiqueta Nacional de Conservação de Energia (ENCE) nos projetos e edificações públicas federais novas ou que recebam retrofit. Brasília. 2014.

Boletim Estatístico de Pessoal e Informações Gerenciais. Vol. 19 n.226. Fevereiro de 2015. Secretaria de Gestão Pública. Brasília. 2015.

Portaria $n^{0}$ 23, de 12 de fevereiro de 2015. Estabelece boas práticas de gestão e uso de energia elétrica e de água nos órgãos e entidades da Administração Pública Direta, autárquica e fundacional e dispõe sobre o monitoramento de consumo desses bens e serviços. Brasília. 2015.

NITERÓI. Lei $\mathbf{n}^{\mathbf{0}}$ 2.340, de 6 de junho de 2006. Estabelece, para projetos de edificações coletivas, a exigência de localização de hidrômetro para medição do consumo de água de cada unidade autônoma. Niterói/RJ. 2006. 
Lei $\mathbf{n}^{0}$ 2.630, de 07 de janeiro de 2009. Disciplina os procedimentos relativos ao armazenamento de águas pluviais para reaproveitamento e retardo da descarga na rede pública. Niterói. 2009.

Lei $n^{0}$ 2.856, de 25 de julho de 2011. Estende as obrigações da Lei ${ }^{\circ} 2.630$, de 07 de janeiro de 2009, instituindo mecanismos de estímulo à instalação de sistema de coleta e reutilização de águas servidas em edificações públicas e privadas. Niterói. 2011.

NORTH CAROLINA DEPARTMENT OF ENVIRONMENT AND NATURAL RESOURCES. Water efficiency manual for commercial, industrial and intitutional facilities. Raleigh. 2009.

NUNES, José A. Tratamento Biológico de Águas Residuárias. Editora ABES. $1^{\mathrm{a}}$ edição. 265p. Porto Alegre. 2010.

NUNES, Riane T. S. Conservação de água em edifícios comerciais: Potencial de uso racional e reuso em shopping centers. Dissertação (Mestrado em Ciências). Universidade Federal do Rio de Janeiro - UFRJ. Rio de Janeiro. 2006. Disponível em http://www.ppe.ufrj.br/ppe/production/tesis/rtsnunes.pdf. Acesso em junho de 2014.

OLIVEIRA, Lucia H. Metodologia para a implantação de programa de uso racional de água em edifícios. Tese (Doutorado em Engenharia). Escola Politécnica da Universidade de São Paulo. São Paulo. 1999.

As bacias sanitárias e as perdas d'água nos edifícios. Ambiente Construído, v.2, n.4, pg. 39-45, out/dez 2002. Porto Alegre. 2002. Disponível em http:// seer.ufrgs.br/ambienteconstruido/article/viewFile/3433/1850. Acesso em agosto de 2013.

OLIVEIRA, Lucia H.; GONÇALVES, Orestes M. Metodologia para a implantação de programa de uso racional de água em edifícios. Boletim Técnico da Escola Politécnica da USP BT/PCC/247. Universidade de São Paulo. São Paulo. 1999. Disponível em http://www.infohab.org.br/acervos/buscaautor/codigoAutor/389. Acesso em agosto de 2013.

ONU - ORGANIZAÇÃO DAS NAÇÕES UNIDAS. United Nations Conference on Sustainable Development. Tradução da Declaração Final da Rio $+20-O$ futuro que queremos. Rio de Janeiro. 2012. Disponível em http://www.rets.org.br/sites/default/files/OFuturo-que-queremos1.pdf. Acesso em outubro de 2012.

The United Nation World Water Development Report 2014. Nova York. 2014. Disponível em http://unesdoc.unesco.org/images/0022/002257/225741e.pdf. Acesso em novembro de 2014.

Resolução 64/292, de 28 de julho de 2010. The human right to water and sanitation. Nova York. 2010. Disponível em http://www.un.org/es/comun/docs/ ?symbol=A/RES/64/292\&lang=E. Acesso em julho de 2014. 
OTTHERPOHL, Ralf. Black, brown, yellow, grey - the new colours of sanitation. Water 21, Londres, Out. 2001. pp. 37-41. Disponível em http://www.iwaponline.com/w21/00305 /w21003050037.htm. Acesso em fevereiro de 2015.

PASSO FUNDO. Lei Complementar $\mathbf{n}^{\mathbf{0}}$ 110, de 08 de janeiro de 2003. Regulamenta a medição individual nas instalações hidráulicas das edificações residenciais multifamiliares e comerciais no município de Passo Fundo, conforme especifica. Passo Fundo. 2003.

PIRACICABA. Lei Complementar $n^{0}$ 169, de 17 de novembro de 2004. Acrescenta dispositivos ao art. 81 da Lei Complementar no 164/04, que "consolida a legislação que disciplina o Parcelamento do Solo do Município de Piracicaba". Piracicaba. 2004.

PONTE, Luis R. Sugestões para aprimoramento de alguns dispositivos da Lei $\mathbf{n}^{\mathbf{0}} \mathbf{8 . 6 6 6}$ para evitar as distorções atuais de sua aplicação oriundas de lacunas pelos vetos presidenciais, de má interpretação ou de maus desejos. Documento apresentado à Comissão Especial da Camara dos Deputados criada para aprimorar a Lei 8.666/1993. Brasília. 2015. Disponível em http://www.caubr.gov.br/wp-content/uploads/2015/04/AP-0804-15-Luis-Ponte-Sugestoes-para-aprimoramentos-de-dispositivos-da-Lei-No-8-666.pdf.

PROENÇA, Lucio C.; GHISI, Enedir. Estimativa de usos finais de água em quatro edifícios de escritórios localizados em Florianópolis. Ambiente Construído, v. 9, n. 3, p. 95108, jul./set. 2009. Porto Alegre. 2009. Disponível em http://seer.ufrgs.br/index.php/ ambienteconstruido/article/view/7718/6625. Acesso em outubro de 2013.

REAL PROPERTY ASSOCIATION OF CANADA. Water management: a benchmark of canadian office buildings. Toronto. 2011. Disponível em https://www.realpac.ca/resource/ resmgr/industry_sustainability_-_water_benchmarking/rp-water-management-and-benc.pdf. Acesso em setembro de 2014.

RECIFE. Lei $\mathbf{n}^{\mathbf{0}}$ 16.759, de 17 de abril de 2002. Institui a obrigatoriedade da instalação de hidrômetros individuais nos edifícios. Recife. 2002.

RIBEIRÃO PRETO. Lei Municipal no 10.489, de 24 de agosto de 2005. Dispõe sobre a instalação de hidrômetros em condomínios. Ribeirão Preto. 2005.

ROCHA, Adilson L.; BARRETO, Douglas; IOSHIMOTO, Eduardo. Caracterização e Monitoramento do Consumo Predial de Água. Programa Nacional de Combate ao Desperdício de Água. Documento Técnico de Apoio E1. Brasília. 1998. Disponível em http://www.pmss.gov.br/index.php/biblioteca-virtual/167-documentos-tecnicos-de-apoio-dta. Acesso em novembro de 2013.

SABESP - COMPANHIA DE SANEAMENTO BÁSICO DO ESTADO DE SÃO PAULO. Programa de uso racional de agua - ações. São Paulo. 2001. Disponível em http://site.sabesp.com.br/Pages/UsoRacionalAgua/Acoes.aspx. Acesso em novembro de 2013. 
O uso racional da água no comércio. Conselho de Desenvolvimento das Cidades da Federação do Comércio do Estado de São Paulo. São Paulo. 2010. Disponível em http://site.sabesp.com.br/uploads/file/asabesp_doctos/cartilha_fecomercio.pdf. Acesso em maio de 2015.

SALLA, Márcio R. et al. Viabilidade técnica de implantação de sistema de aproveitamento de água pluvial para fins não potáveis em universidade. Revista Ambiente Construído, v. 13, n. 2, p. 167-181, abr./jun. 2013. Porto Alegre. 2013. Disponível em http://www.scielo.br/pdf/ac/v13n2/a13v13n2.pdf. Acesso em junho de 2014.

SALVADOR. Lei Municipal $n^{\mathbf{0}}$ 7.780, de 21 de dezembro de 2009. Dispõe sobre a instalação de hidrômetros individuais e dá outras providências. Salvador. 2009.

SANT'ANA, Daniel R. A socio-technical study of water consumption and water conservation in Brazilian dwellings. Tese (Doutorado). Oxford Brookes University. Oxford. 2011.

Aproveitamento de água pluvial no Complexo Central de Tecnologia do

Banco do Brasil. In: Terra: qualidade de vida, mobilidade e segurança nas cidades. João Pessoa. 2013.

Uso e Conservação de Água em Edificações. Apostila do curso Reabilita Curso de especialização em reabilitação ambiental sustentável arquitetônica e urbanística. Brasília. 2015.

SANT'ANA, Daniel R.; BOEGER, Louise; MONTEIRO, Lilian. Aproveitamento de águas pluviais e o reuso de águas cinzas em edifícios residenciais de Brasília - parte 2: viabilidade técnica e econômica. In: Revista Paranoá no 10, pg. 85-94. Brasília. 2013.

SÃO PAULO. Lei $\mathbf{n}^{\mathbf{0}} \mathbf{1 3 . 2 7 6}$, de 4 de janeiro de 2002. Torna obrigatória a execução de reservatório para as águas coletadas por coberturas e pavimentos nos lotes edificados ou não, que tenham área impermeabilizada superior a $500,00 \mathrm{~m}^{2}$ (quinhentos metros quadrados). São Paulo. 2002.

Lei $\mathbf{n}^{0}$ 13.309, de 31 de janeiro de 2002. Dispõe sobre o reuso de água não potável e dá outras providências. São Paulo. 2002.

Lei $\mathrm{n}^{\circ}$ 14.018, de 28 de junho de 2005. Institui o programa municipal de conservação e uso racional da água em edificações e dá outras providências. São Paulo. 2005.

SENRA, João B.; VILELLA, Wagner M.; ANDRÉ, Marco A. Legislação e política nacional de recursos hídricos. Brasília. 2012. Disponível em http://www.upf.br/coaju/index.php /downloads/artigos?download=725:Artigo. Acesso em fevereiro de 2014.

SHIKLOMANOV, Igor A. A Guide to the World's Fresh Water Resources. Chapter 2 World Fresh Water Resources. Stockholm Environment Institute. Oxford. 1993. 
SIDNEY WATER. Multi-level individual metering guide. Sidney. 2014. Disponível em https://www.sydneywater.com.au/web/groups/publicwebcontent/documents/document/zgrf/m dq1/ edisp/dd_045282.pdf. Acesso em outubro de 2014.

SILVA, Gilmar. Aproveitamento de água de chuva em um prédio industrial e numa escola pública - estudo de caso. Tese (Doutorado em Engenharia Civil). Universidade Estadual de Campinas. Campinas. 2007. Disponível em http://www.bibliotecadigital. unicamp.br/document/?code=vtls000441485. Acesso em agosto de 2013.

SILVA, Gisele S.; TAMAKI, Humberto O.; GONÇALVES, Orestes M. Implementação de programas de uso racional da água em campi universitários. Ambiente Construído, v. 6, n.1, p. 49-61, jan./mar. 2006. Porto Alegre. 2006. Disponível em http://seer.ufrgs.br/index.php /ambienteconstruido/article/view/3679/2045. Acesso em julho de 2013.

SILVA, Joene S. A eficiência do brise-soleil em edifícios públicos de escritórios: estudo de casos no Plano Piloto de Brasília. Dissertação (Mestrado em Arquitetura). Universidade de Brasília - UnB. Brasília. 2007. Disponível em http://repositorio.unb.br/ handle/10482/2975?mode=full. Acesso em setembro de 2013.

SILVA, Samara F. et al. Rational Consumption of Water in Administrative Public Buildings: The Experience of the Bahia Administrative Center, Brazil. Water, Basel (Suíça), v. 6, p. 2552-2574, setembro 2014. Disponível em http://www.mdpi.com/20734441/6/9/2552. Acesso em novembro de 2014.

SILVA, Sérgio R. S. Avaliação do sistema de medição individualizada de água em prédios populares situados na cidade de Salvador-Bahia. Universidade Federal da Bahia. Dissertação (Mestrado Profissional em Gerenciamento e Tecnologia Ambiental no Processo Produtivo). Salvador. 2010. Disponível em https://repositorio.ufba.br/ri/handle/ri/9585. Acesso em outubro de 2014.

SOUZA FILHO, Aloísio F. et al. A hidrometração individualizada como instrumento disciplinador de consumo. In: Anais do $23^{\circ}$ Congresso Brasileiro de Engenharia Sanitária e Ambiental. Campo Grande/MS. 2005. Disponível em http://www.ctec.ufal.br/professor/vap/ Hidrometracaoindividual.pdf. Acesso em setembro de 2014.

STATE OF CALIFORNIA. Water efficiency guide for business managers and facility engineers. Department of Water Resources. Califórnia. 1994.

SUSTAINABLE DEVELOPMENT TECHNOLOGY CANADA. Commercial buildings eco-efficiency. Otawa. 2007. Disponível em https://www.sdtc.ca/uploads/2015/ EcoEfficiency-Buildings.pdf. Acesso em outubro de 2014.

TAMAKI, Humberto O. A medição setorizada como instrumento da gestão da demanda de água em sistemas prediais - Estudo de caso: Programa de Uso Racional da água da Universidade de São Paulo. Escola Politécnica da Universidade de São Paulo. Dissertação 
(Mestrado em Engenharia). São Paulo. 2003. Disponível em http://www.teses.usp.br/teses/ disponiveis/3/3146/tde-12042005-113615/pt-br.php. Acesso em agosto de 2014.

TANNURI, Guillermina; VAN BELLEN, Hans M. Indicadores de desempenho ambiental evidenciados nos relatórios de sustentabilidade: uma análise à luz de atributos de qualidade. Revista de Gestão Social e Ambiental, v. 8, n. 1, pp. 2-19. São Paulo. 2014. Disponível em www.revistargsa.org/rgsa/article/view/790. Acesso em novembro de 2014.

TCU - TRIBUNAL DE CONTAS DA UNIÃO. Obras públicas: recomendações básicas para contratação e fiscalização de obras de edificações públicas. Brasília. $3^{\mathrm{a}}$ ed. 2013. 94p.

Relatório de Atividades do $1^{\circ}$ trimestre de 2015. Brasília. 2015.

TOMAZ, Plínio. Conservação de água. Guarulhos. 2009. Disponível em http:// www.pliniotomaz.com.br/downloads/livros/livro_conservacao/livro_conservacao_agua.pdf. Acesso em agosto de 2013.

Água: pague menos. Guarulhos. 2010. Disponível em http:// www.pliniotomaz.com.br/downloads/livros/livro_pague_menos/livro_pague_menos.pdf.

Acesso em agosto de 2013.

UNITED STATES DEPARTMENT OF ENERGY. Executive Order n⿳ 13423. Washington. 2009. Disponível em energy.gov/eere/femp/executive-order-13423. Acesso em abril de 2014.

Increasing Federal Office Building Water Efficiency. Federal Energy Management Program. Washington. 2010. Disponível em http://www1.eere.energy.gov/ femp/pdfs/waterefficiency_fedoffices.pdf. Acesso em outubro de 2014.

VARGAS, Marcelo C. A governança das águas urbanas no território: dependência da trajetória e inovação institucional. In: Anais de Encontros Nacionais da ANPUR. Rio de Janeiro. 2013.

VICKERS, Amy. Handbook of water use and conservation. Amherst: Water Plow Press, 2001.

VIÇOSA. Lei $\mathbf{n}^{\mathbf{0}}$ 1.440, de 13 de junho de 2001. Dispõe sobre normas de controle de excesso de consumo de água distribuída para uso humano. Viçosa. 2001.

VIGGIANO, Mário. Edifícios Públicos Sustentáveis. Brasília. 2ª ed. 2010. 87p.

VITÓRIA. Lei $\mathbf{n}^{\mathbf{0}} \mathbf{8 . 3 5 4}$, de 24 de setembro de 2012. Dispõe sobre a obrigatoriedade de instalações hidráulicas que permitam a medição isolada do consumo de água de cada uma de suas unidades habitacionais e dá outras providências. Vitória/ES. 2012.

WAGGETT, Rachel; AROTSKY, Catherine. Water key performance indicators and benchmarks for offices and hotels. Construction Industry Research and Information 
Association. CIRIA Publication C657. Londres. 2006. Disponível em http://www.ciria.org $/$ ItemDetail iProductcode=C657\&Category=BOOK. Acesso em novembro de 2014.

WWAP - UNITED NATIONS WORLD WATER ASSESSMENT PROGRAMME. The United Nations World Water Development Report 2015: Water for a Sustainable World. UNESCO. Paris. 2015. 


\section{ANEXO 1}

\section{Consumo de água}

Nesta página deverá ser informado, de forma estimativa, seu consumo diário de água nas dependências do TCU, por meio da frequência de uso dos aparelhos sanitários.

8. Qual é a sua frequência estimada de uso no TCU das peças sanitárias abaixo:

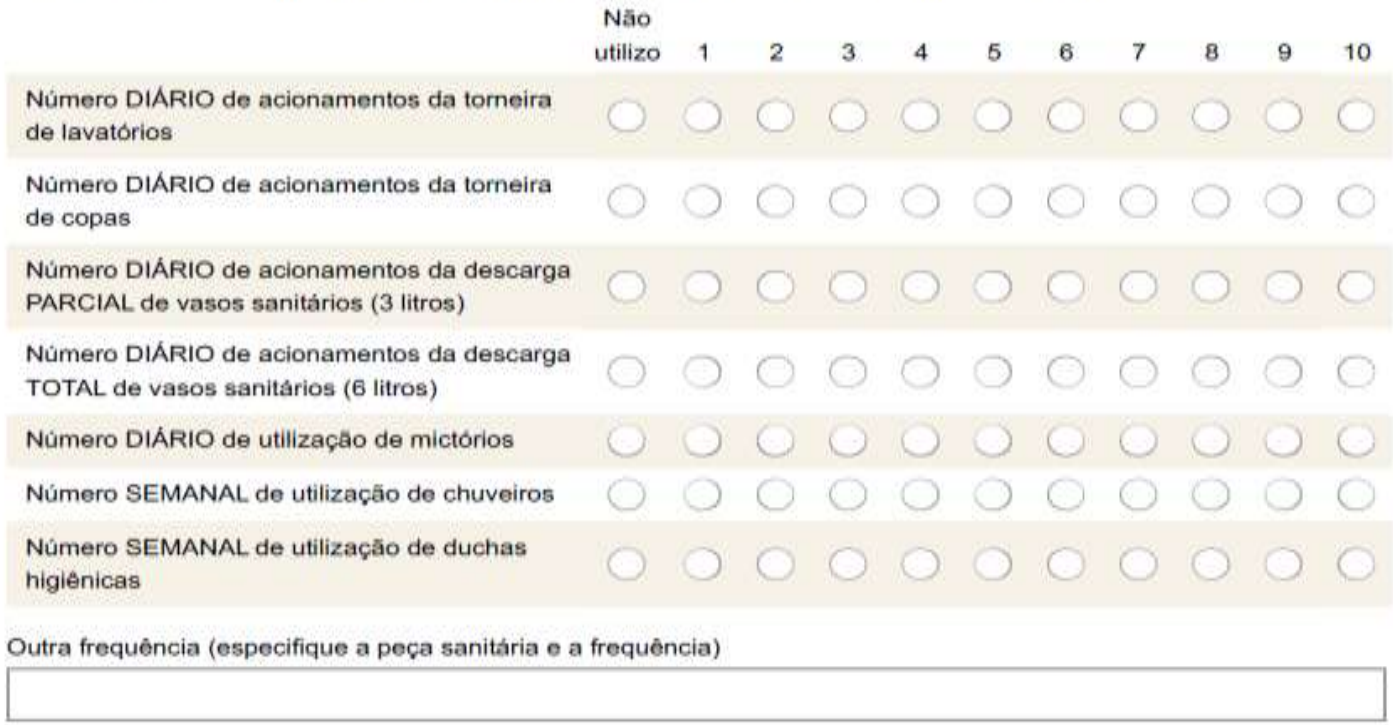

Tempo de consumo de água e uso de filtros de parede

Nesta página deverá ser informado, se for o caso, de formaestimada, qual é o tempo de uso de alguns aparelhos sanitários e qual é o seu consumo diário estimado de água nos filtros de parede instalados nas copas do TCU.

9. Qual é o tempo estimado, de utilizaçâo de algumas peças sanitárias informadas na pergunta anterior;

$\begin{array}{lllllll}\text { Na) } & 15 & 30 & 45 & 1 & 2\end{array}$ utilizo segundos segundos segundos minuto minutos 3 minutos 4 minutos 5 minutos 6 minutos 7 minutos 8 minutos 9 minutos 10 minutos Chuveiros

Tomeiras

da coga

Duchas higiênicas

Outra trequencia (especifique a peça sanitaria e a frequencia)

10. Qual é a quantidade média diária de água, em mililitros, que você estima que consuma nos filtros de água instalados nas copas do TCU? (obs: 1 copo plástico $=200 \mathrm{ml}$ )
1) Nầ utilizo
(C) 500
1500
200
(C) 600
(C) 2000
300
800
(C) 2500
400
1000
3000
Outro consumo (especifique a quantidade) 
ANEXO 2

ENTREVISTA ESTRUTURADA - RESPONSÁVEL RESTAURANTE

\begin{tabular}{||l|l|}
\hline \multicolumn{2}{|l|}{ Órgão Público: } \\
\hline Responsável setor: & Telefone: \\
\hline E-mail: & \\
\hline
\end{tabular}

1. a) Qual é o número de funcionários terceirizados da empresa contratada para gerenciar o restaurante deste órgão?

b) É possível disponibilizar o último edital de contratação desses serviços?

$\square \operatorname{Sim} \quad \square$ Não

2. a) Qual é o número médio de refeições diárias servidas?

b) Qual é o número máximo de refeições diárias que podem ser servidas?

3. Há instalado ou previsto algum equipamento economizador de água nas torneiras da cozinha do restaurante deste órgão?

$\square \operatorname{Sim} \quad \square$ Não

4. a) Há algum controle em relação ao consumo de água na lavagem e manipulação de alimentos?

$\square$ Sim $\square$ Não

b) Há algum controle em relação ao consumo de água na lavagem de pisos?

$\square$ Sim $\quad \square$ Não

c) Se sim, preencher tabela abaixo:

\begin{tabular}{||c|c|c|c|c|c||}
\hline $\begin{array}{c}\text { Tipo de } \\
\text { Lavagem }\end{array}$ & $\begin{array}{c}\text { Frequência de } \\
\text { Lavagem }\end{array}$ & $\begin{array}{c}\text { Tipo de } \\
\text { equipamento }\end{array}$ & $\begin{array}{c}\text { Área Total do } \\
\text { Ambiente }\end{array}$ & $\begin{array}{c}\mathrm{N}^{\circ} \text { de Baldes } \\
\text { (ou) Vazão }\end{array}$ & Tempo \\
\hline $\begin{array}{c}\text { Preparo de } \\
\text { alimentos }\end{array}$ & & & & & \\
\hline $\begin{array}{c}\text { Lavagem de } \\
\text { pratos/talheres }\end{array}$ & & & & & \\
\hline $\begin{array}{c}\text { Lavagem de } \\
\text { panelas }\end{array}$ & & & & & \\
\hline $\begin{array}{c}\text { Limpeza do } \\
\text { piso }\end{array}$ & & & & & \\
\hline
\end{tabular}

6. a) Há registro de circuito interno de TV da área de manipulação de alimentos da cozinha do restaurante?

$\square$ Sim $\square$ Não

b) Se sim, é possível disponibilizar as gravações de uma semana, para verificação da frequência e tempo de utilização das torneiras e da lavagem dos pisos?

$\square \operatorname{Sim} \quad \square$ Não

7. a) Há registro em separado de consumo de água exclusivamente do restaurante?

$\square \operatorname{Sim} \quad \square$ Não

b) Se sim, é possível disponibilizar as leituras de um período entre uma semana e quinze dias, para verificação do consumo diário de água do restaurante?

$\square \operatorname{Sim} \quad \square$ Não 


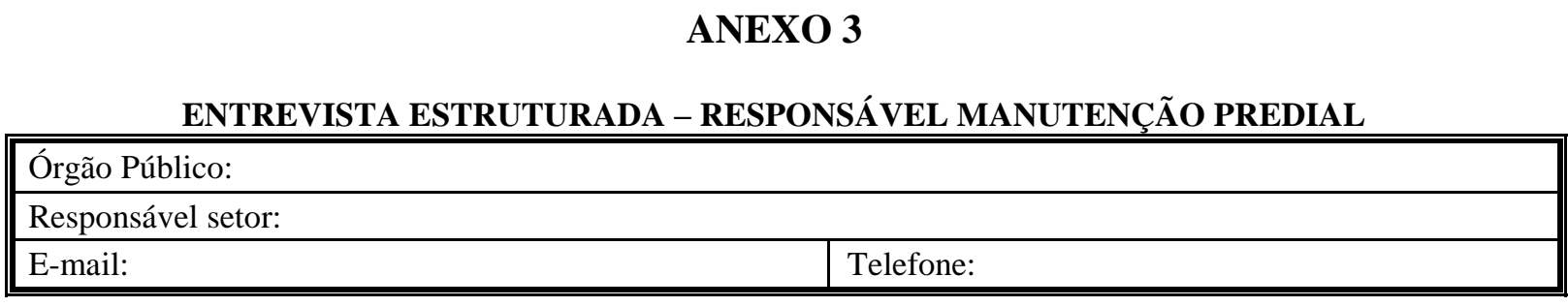

1. a) Qual é o número de funcionários terceirizados de manutenção predial que trabalham neste órgão?

b) Qual é o número de funcionários terceirizados de cada especialidade abaixo?
Instalações Hidráulicas:
Ar Condicionado:

c) É possível disponibilizar o último edital de contratação desses serviços?

2. a) Há algum manual de orientação acerca dos procedimentos dos funcionários terceirizados em situações cotidianas de manutenção predial?

b) É possível disponibilizá-lo?

$\square \operatorname{Sim}$

$\square$ Não

$\square \operatorname{Sim} \quad \square$ Não

3. Há instalado ou previsto algum sistema de aproveitamento de águas pluviais ou de reuso de água no conjunto arquitetônico deste órgão?

4. Há uma rede de tubulação distinta, apenas para a alimentação de água em vasos
sanitários, separada das torneiras elou chuveiros nos banheiros?

$\square \operatorname{Sim} \quad \square$ Não

$\square \operatorname{Sim} \quad \square$ Não

5. a) Há dados acerca de perdas de água detectadas por vazamentos na rede?

b) Se houver, você poderia disponibilizar esses dados?

$\square \operatorname{Sim} \quad \square$ Não

c) Há algum teste mensal para detecção destes vazamentos?

$\square \operatorname{Sim} \quad \square$ Não

$\square \operatorname{Sim} \quad \square$ Não

$\square \operatorname{Sim} \quad \square$ Não

$\square \operatorname{Sim} \quad \square$ Não

d) Há manutenção preventiva?

$\square \operatorname{Sim} \quad \square$ Não

e) Se sim, estão especificados os procedimentos e a frequência de ações em algum manual orientativo?

f) É possível disponibilizá-lo?

$\square \operatorname{Sim} \quad \square$ Não

6. Houve alguma reforma no sistema hidráulico recentemente que prevê mudanças para $\quad \square$ Sim $\quad \square$ Não incorporação de tecnologias para conservação de água?

7. a) Este órgão é dotado de sistema de ar condicionado com central de água gelada?

b) Em média, qual é o consumo mensal de água usado na torre de resfriamento?

c) Há variação de consumo de água entre inverno e verão ou nos períodos seco e chuvoso?

d) Se sim, há registro desses dados que possam ser disponibilizados?

8. a) Já foi feito algum programa educativo neste órgão para redução de consumo de $\quad \square \mathrm{Sim} \quad \square$ Não água?

b) Se sim, o que foi proposto para reduzir o consumo de água?
$\square$ Mudanças nos hábitos de higiene
$\square$ Mudanças nos hábitos de limpeza dos pisos
$\square$ Mudanças nos hábitos de limpeza dos veículos
$\square$ Mudanças nos hábitos de rega do jardim
$\square$ Reparo de vazamentos
$\square$ Instalação de equipamentos economizadores de água
$\square$ Outros (especifique)

9.a) Seria possível disponibilizar as contas de água dos últimos 3 anos da(s) $\square$ Sim $\square$ Não edificação(ôes) utilizada(s) por este órgão?

b) Levando em consideração os últimos períodos de medições, o consumo de água deste $\quad \square$ Sim $\quad \square$ Não órgão pode ser considerado como típico?

c) Se não, por favor especifique o que possa ter influenciado o consumo de água deste órgão e, se for o caso, especificamente em que período.

\begin{tabular}{|l|}
\hline \\
\hline \\
\hline \\
\hline \\
\hline \\
\hline
\end{tabular}


ANEXO 4

ENTREVISTA ESTRUTURADA - RESPONSÁVEL LIMPEZA

\begin{tabular}{||l|l||}
\hline Órgão Público: & \multicolumn{2}{|l||}{} \\
\hline Responsável setor: & Telefone: \\
\hline E-mail: &
\end{tabular}

1. a) Qual é o número de funcionários terceirizados de limpeza que trabalham neste órgão?

2. Dentre as atividades abaixo, como a água é utilizada e com que frequência?

DADOS SOBRE LAVAGEM DE ÁREAS SECAS

\begin{tabular}{||c|c|c|c|c|c||}
\hline Ambiente & $\begin{array}{c}\text { Frequência de } \\
\text { Lavagem }\end{array}$ & $\begin{array}{c}\text { Tipo de } \\
\text { equipamento }\end{array}$ & $\begin{array}{c}\text { Área Total do } \\
\text { Ambiente }\end{array}$ & $\begin{array}{c}\mathrm{N}^{\circ} \text { de Baldes } \\
\text { (ou) Vazão }\end{array}$ & $\begin{array}{c}\text { Tempo de } \\
\text { uso }\end{array}$ \\
\hline $\begin{array}{c}\text { Sanitários de uso } \\
\text { público }\end{array}$ & & & & & \\
\hline $\begin{array}{c}\text { Sanitários } \\
\text { privativos / PNE }\end{array}$ & & & & & \\
\hline Outros sanitários & & & & & \\
\hline Vestiários & & & & & \\
\hline Copas & & & & & \\
\hline Outro: & & & & & \\
\hline
\end{tabular}

DADOS SOBRE LAVAGEM DE ÁREAS MOLHADAS

\begin{tabular}{|c|c|c|c|c|c|c|}
\hline Ambiente & $\begin{array}{c}\text { Frequência de } \\
\text { Lavagem }\end{array}$ & $\begin{array}{c}\text { Tipo de } \\
\text { equipamento }\end{array}$ & $\begin{array}{c}\text { Área Total do } \\
\text { Ambiente }\end{array}$ & $\begin{array}{c}\mathrm{N}^{\circ} \text { de Baldes } \\
\text { (ou) Vazão }\end{array}$ & Tempo & $\begin{array}{c}\mathrm{N}^{\circ} \text { de } \\
\text { Descargas }\end{array}$ \\
\hline \multicolumn{7}{|l|}{$\begin{array}{l}\text { Sanitários de } \\
\text { uso público }\end{array}$} \\
\hline \multicolumn{7}{|l|}{$\begin{array}{c}\text { Sanitários } \\
\text { privativos / } \\
\text { PNE }\end{array}$} \\
\hline \multicolumn{7}{|l|}{$\begin{array}{c}\text { Outros } \\
\text { sanitários }\end{array}$} \\
\hline \multicolumn{7}{|l|}{ Vestiários } \\
\hline \multicolumn{7}{|l|}{ Copas } \\
\hline Outro: & & & & & & \\
\hline
\end{tabular}

3. a) Existem torneiras específicas nos banheiros para uso na limpeza?
$\square \mathrm{Sim}$
$\square$ Não

4. a) Existem tanques/lavadoras para limpeza de panos de chão ou utensílios de limpeza?
$\square \operatorname{Sim}$
$\square$ Não

b) É possível estimar o tempo de abertura da torneira ao utilizar os tanques?

c) É possível estimar o tempo médio de abertura da torneira ao limpar um pano de chão?

d) É possível estimar o tempo médio total de abertura da torneira de limpeza nos banheiros? 
ANEXO 5

ENTREVISTA ESTRUTURADA - RESPONSÁ VEL JARDINAGEM / IRRIGAÇÃO

\begin{tabular}{||l|l||}
\hline \hline Órgão Público: \\
\hline Responsável pelo setor: \\
\hline E-mail: & Telefone: \\
\hline Área Verde: & Área Irrigada: \\
\hline
\end{tabular}

1. a) Qual é o número de funcionários terceirizados de jardinagem que trabalham neste órgão?

b) É possível disponibilizar o último edital de contratação desses serviços?

$\square$ Sim $\quad$ Não

2. a) Há algum manual de orientação acerca dos procedimentos dos funcionários terceirizados acerca do tratamento dos jardins, especialmente no que diz respeito ao consumo de água?
$\square \operatorname{Sim}$
$\square$ Não
b) É possível disponibilizá-lo?
$\square$ Sim $\square$ Não
3. a) Os jardins deste órgão são dotados de sistema de irrigação?
$\square$ Sim $\quad$ Não
b) É automatizado?
$\square \operatorname{Sim} \quad \square$ Não

DADOS SOBRE IRRIGAÇÃO DE JARDINS

\begin{tabular}{|c|c|c|c|c|c|c|}
\hline Ambiente & $\begin{array}{l}\text { Período do } \\
\text { Ano }\end{array}$ & $\begin{array}{l}\text { Frequência de } \\
\text { Irrigação }\end{array}$ & Equipamento & Vazão & Tempo & Área \\
\hline & & & & & & \\
\hline & & & & & & \\
\hline & & & & & & \\
\hline & & & & & & \\
\hline & & & & & & \\
\hline & & & & & & \\
\hline & & & & & & \\
\hline
\end{tabular}


ANEXO 6

ENTREVISTA ESTRUTURADA - RESPONSÁVEL PROJETOS ARQUITETURA / INSTALAÇÕES

\begin{tabular}{||l|l|}
\hline \hline Órgão Público: \\
\hline Responsável setor: & Telefone: \\
\hline E-mail: & \\
\hline
\end{tabular}

1. a) Qual é o número de profissionais envolvidos com o desenvolvimento de projetos de instalações prediais hidrossanitárias neste órgão?

b) Os projetos são desenvolvidos de que forma?

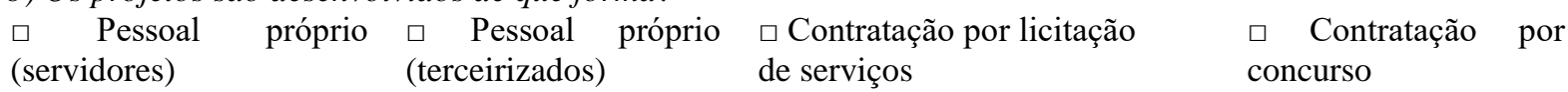

2. a) Há incorporação de requisitos de sustentabilidade, voltados à conservação de água, na construção de novas edificações neste órgão?

$\square \mathrm{Sim} \quad \square$ Não

b) E no caso de reformas?

$\square \operatorname{Sim} \quad \square$ Não

3. Há previsão para reforma do prédio existente (ou de prédios antigos do conjunto edificado) que incluem a instalação de alguma das tecnologias conservadoras de água abaixo?

$\square$ Equipamentos economizadores $\square$ Aproveitamento de águas pluviais $\square$ Reúso de águas cinzas/negras 4. a) Há previsão da instalação de tecnologias conservadoras de água acima nas edificações existentes deste órgão, no caso de não estar instalada uma dessas benfeitorias?

$\square$ Sim. Qual?

口 Não

b) Quem toma a decisão de implementar essas tecnologias conservadoras de água nas especificações técnicas?

$\checkmark$ Projetista $\square$ Diretor, coordenador, gerente, $\square$ Ordenador de despesas $\square$ Diretor-geral, Secretário-geral, chefe do setor (coordenador (coordenador financeiro) Ministro, Presidente do órgão técnico)

c) A decisão tomada é política ou técnica?
Política
$\square$ Técnica
$\square$ Ambas

(autoridade política)

d) Essa decisão é baseada em que tipo de dados?

$\square$ Ambientais $\square$ Desempenho $\square$ Financeiros $\square$ Outro:

5. Você acreditaria que seria desenvolvido um estudo de viabilidade econômica para a implantação de tecnologias conservadoras de água desse(s) sistema(s)?

$\square \operatorname{Sim} \quad \square$ Não

6. a) Você acredita que haveria abertura do tomador de decisões quanto à implantação de tecnologias conservadoras de água, com argumentos da área técnica exclusivamente da área de sustentabilidade e proteção do meio ambiente, sem considerar o aspecto econômico?

$\square$ Sim $\square$ Não

b) E no caso de se comprovar a viabilidade financeira (pay-back) do projeto?

$\square$ Sim $\square$ Não

7. Houve, em algum momento, a realização de um diagnóstico do consumo de água ou auditoria hidráulica de algum edifício deste órgão?

$\square$ Sim $\square$ Não 